EDUARDO ROBERTO ALCÂNTARA DEL-CAMPO

EXAME E LEVANTAMENTO TÉCNICO PERICIAL DE LOCAIS DE INTERESSE À JUSTIÇA CRIMINAL: ABORDAGEM DESCRITIVA E CRÍTICA

\author{
DisSERTAÇÃo de MESTRAdo
}

Orientadora: Profa. Dra. Irene Batista MuAKAd

FACULDADE DE DIREITO DA USP

SÃO PAULO

2008 


\title{
EXAME E LEVANTAMENTO TÉCNICO PERICIAL DE LOCAIS DE INTERESSE À JUSTIÇA CRIMINAL: ABORDAGEM DESCRITIVA E CRÍTICA
}

\author{
Dissertação apresentada à Banca Examinadora da \\ Faculdade de Direito da Universidade de São Paulo, como \\ exigência parcial para a obtenção do título de Mestre em \\ Medicina Legal, sob orientação da Profa. Dra. Irene \\ Batista Muakad
}

FACULDADE DE DIREITO DA USP

SÃO PAULO

2008 


\section{FICHA CATALOGRÁFICA}

(Elaborada pelo Serviço de Processos Técnicos da Biblioteca da Faculdade de Direito da USP)

Del-Campo, Eduardo Roberto Alcântara

Exame e levantamento técnico pericial de locais de interesse à justiça criminal : abordagem descritiva e crítica / Eduardo Roberto Alcântara Del-Campo. - São Paulo : E. R. A. Del-Campo, 2008.

252 f. : il. (algumas color.)

Dissertação (mestrado) - Faculdade de Direito da USP, 2008

Orientador: Prof ${ }^{a}$. Irene Batista Muakad

Bibliografia.

Notas de rodapé.

1. Perícia técnica 2. Medicina legal 3. Criminalística 4. Local do crime. I. Título. 


\section{Banca Examinadora}

Profa. Dra. Irene Batista Muakad Orientadora

Prof. Dr.

Prof. Dr. 
À minha esposa Luciana e aos meus filhos: Victoria, Gabriela e Vinicius, que trouxeram um novo sentido a minha vida. 


\section{AGRADECIMENTOS}

Ao saudoso Professor Doutor José Lopes Zarzuela, colega e amigo inesquecível, Emérito Perito Criminal e mestre da Academia de Polícia de São Paulo e da Faculdade de Direito da Universidade de São Paulo, sem cujos ensinamentos este trabalho não teria sido possível.

À estimada Professora Doutora Irene Batista Muakad, pela paciência, atenção e sincera amizade e, principalmente, pelo estímulo durante minha orientação.

Ao Professor Doutor Alvino Augusto de Sá e ao Professor Doutor Roberto Augusto de Carvalho Campos, ambos do Departamento de Direito Penal, Medicina Forense e Criminologia da Faculdade de Direito da Universidade de São Paulo, pelas observações e correções feitas ao trabalho inicial de qualificação.

Ao Doutor Celso Perioli, Coordenador da Superintendência da Polícia Técnico-Científica do Estado de São Paulo, que sempre atendeu às minhas solicitações prestando informações e esclarecimentos absolutamente imprescindíveis para a consecução deste trabalho.

Ao desenhista e amigo, Luiz Almeida, que soube interpretar minhas descrições e transformá-las nas gravuras originais que ilustram o presente trabalho. 


\section{RESUMO}

DEL-CAMPO, Eduardo R. A. Exame e levantamento técnico pericial de locais de interesse à Justiça Criminal: abordagem descritiva e crítica. São Paulo, 2008. 274 f. Dissertação (Mestrado) - Faculdade de Direito, Universidade de São Paulo, São Paulo, 2009.

O panorama das ciências forenses no Brasil poderia ser mais auspicioso. O aumento incontrolável das dissensões sociais e da criminalidade comum, o crescimento de facções do crime organizado, o surgimento de novas modalidades de delitos, os desastres de massa e o incremento de novas tecnologias são fatores que apontam no sentido de uma maior demanda por exames periciais e da crescente complexidade dos trabalhos relacionados com as ciências forenses. Paradoxalmente, a falta de investimentos públicos na área, os baixos salários, a ausência de perspectiva profissional e o acúmulo de serviço são alguns dos fatores que claramente influenciam na queda de qualidade do trabalho técnico. Não se publicam mais obras de Criminalística e Medicina Legal no país. As revistas especializadas são poucas e os cursos de Direito paulatinamente vão destinando cada vez menos espaço para aquelas que, ao lado da formação jurídica específica, deveriam ser as matérias principais na formação do bacharel, especialmente daqueles que militam na área penal. Além disso, e exatamente pela natureza técnica da matéria, poucos são os questionamentos que recaem sobre a cadeia de custódia ou sobre a validade das provas periciais apresentadas pelos organismos públicos encarregados da prevenção e da repressão criminal. Este trabalho pretende apresentar uma breve revisão dos dispositivos que regulamentam a prova pericial no sistema processual penal, recentemente alterados pela Lei n. 11.690, de 09/06/08, a estrutura da polícia científica e os procedimentos periciais de levantamento dos locais de interesse à Justiça Criminal, desde o momento que antecede à perícia até a entrega do relatório técnico, apontando seus limites, deficiências e qualidades.

Palavras-chave: Perícia; Perito; Exame de corpo de delito; Local de crime; Preservação de local de crime; Ciências Forenses; Medicina Legal; Criminalística. 


\begin{abstract}
DEL-CAMPO, Eduardo R. A. Examination and technical survey on sites of the Criminal Justice’s interest: descriptive and critical approach. São Paulo, 2008. 274 f. Dissertation (Mestrado) - School of Law, University of São Paulo, São Paulo, 2009.

The overview of forensic sciences in Brazil could be more auspicious. The uncontrollable raise of social disagreements and common criminality, the increase of organized crime factions, the appearance of new forms of crime, mass disasters and improvement of new technologies are factors which leads to a sense of higher demand for expert examinations and an increasing complexity of works related to forensic sciences. Paradoxically, the absence of public investment in the area, the low wages, the lack of professional perspectives and the accrual of workload are some of the factors that clearly influence the decline of quality of technical works. There are few new publications about Criminalistics and Legal Medicine in Brazil. The specialized journals are few and law schools are gradually giving less space for those which, like specific legal matters, should be the main ones in the training of new lawyers, especially those who work with criminal law. Besides that, and exactly because of the technical nature of the matter, few are the questions which fall upon the chain of custody or the validity of the expert evidence shown by the public organisms which are responsible for the criminal prevention and repression. This dissertation intends to present a brief review of the articles that regulate the expert evidence in the criminal procedural law, recently altered by Law $\mathrm{n}^{\circ} 11.690$ of 09/06/08, and the structure of forensic science and the expert procedures to gather places of interest to the Criminal Justice, from the moment preceding the expertise until the delivery of the technical report, pointing out its limitations, shortcomings and qualities.
\end{abstract}

Key words: Expert examination; Expert, body of the offense; Crime scene; Crime scene preservation; Forensic Sciences; Legal Medicine; Criminalistics. 
ABNT - Associação Brasileira de Normas Técnicas.

ABO - Grupo de antígenos eritrocitários descobertos pelo cientísta austríaco Karl Landsteiner no início do século XX.

ANP - Agência Nacional do Petróleo.

ANVISA - Agência Nacional de Vigilância Sanitária.

CAD - Computer Aided Design.

CC - Código Civil.

$\mathrm{CD}$ - Compact disc.

CETESB - Companhia de tecnologia de Saneamento Ambiental.

CFM - Conselho Federal de Medicina.

CGCRE - Coordenação Geral de Credenciamento.

CID 10 - Classificação Estatística Internacional de Doenças e Problemas Relacionados à Saúde (10ª Revisão).

CITAC - Cooperation on International Traceability in Analytical Chemistry.

CLT - Consolidação das Leis do Trabalho.

$\mathrm{CP}$ - Código Penal.

CPC - Código de Processo Civil.

CPM - Código Penal Militar.

CPP - Código de Processo Penal.

CPPM - Código de Processo Penal Militar.

CR - Coeficiente de correlação.

CV - Coeficiente de variação.

DATASUS - Banco de dados do Sistema Único de Saúde.

DEPC - Departamento Estadual de Polícia Científica.

DGP - Delegacia Geral de Polícia.

DHPP - Departamento de Homicídios e Proteção à pessoa.

DIRD - Departamento de Investigação e Registros Diversos.

DNA - Deoxyribonucleic acid ou, em português, ácido desoxirribonucleico (ADN).

DP - Desvio padrão.

DPC - Departamento de Produtos Controlados.

DPCRIM - Divisão de Perícias e Dados Criminalísticos (do INC).

DPER - Divisão de Perícias (do INC). 
DPME - Departamento de Perícias Médicas do Estado.

DVD - Digital video disc.

EDS - Energy Dispersive Spectrometer.

EURACHEM - Rede de organizações Européias que tem como objetivo o estabelecimento de um sistema de rastreabilidade internacional de medições químicas e a promoção de boas práticas da qualidade.

FDA - Food and Drug Administration.

GATE - Grupo de Operações Táticas Especiais da Polícia Militar.

HLA - Do inglês Human Leukocyte Antigen ou sistema antígeno leucocitário humano.

IAL - Instituto Adolfo Lutz.

IB - Instituto Biológico.

IBGE - Instituto Brasileiro de Geografia e Estatística.

IC - Instituto de Criminalística de São Paulo.

ICH - International Conference on Harmonisation.

IEC - International Electrotechnical Commission.

IIRGD - Instituto de Identificação Ricardo Gumbleton Daunt.

IMESC - Instituto de Medicina Social e Criminologia de São Paulo.

IML - Instituto Médico Legal.

INC - Instituto Nacional de Criminalística.

INI - Instituto Nacional de Identificação.

INMETRO - Instituto Nacional de Metrologia, Normalização e Qualidade Industrial.

IPEM - Instituto de Pesos e Medidas do Estado de São Paulo.

IPEN - Instituto de Pesquisas Energéticas e Nucleares.

IPT - Instituto de Pesquisas Tecnológicas do Estado de SP.

ISO - International Organization for Standardization.

LCP - Lei das Contravenções Penais.

LOD - Limite de detecção.

LOQ - Limite de quantificação.

MN - Sistema de antígenos sanguíneos.

MRC - Material de Referência Certificado.

NATA - National Association of Testing Authorities.

NBR - Norma brasileira.

OMS - Organização Mundial de Saúde.

PSA - Prostate specific antigen. 
$\mathrm{Rh}$ - Fator Rh (rhesus) - Grupo de antígenos eritrocitários envolvido em reações transfusionais hemolíticas e na doença hemolitica do recém-nascido.

RT - Revista dos Tribunais.

SEPAEL - Serviço de Perícias em Audiovisual e Eletrônicos (do INC).

SEPCONT - Serviço de Perícias Contábeis e Econômicas (do INC).

SEPDOC - Serviço de Perícias Documentoscópicas (do INC).

SEPEMA - Serviço de Perícias de Engenharia e Meio Ambiente (do INC).

SEPINF - Serviço de Perícias em Informática (do INC).

SEPLAB - Serviço de Perícias de Laboratório e de Balística (do INC).

SESDEC - Secretaria de Estado da Segurança e Defesa da Cidadania.

SETEC - Seção Técnico-Científica (do Instituto Nacional de Criminalística).

SIF - Serviço de Inspeção Federal.

SPTC - Superintendência da Polícia Técnico-Científica.

STF - Supremo Tribunal Federal.

STJ - Superior Tribunal de Justiça.

SUS - Sistema Único de Saúde.

SVO - Serviço de Verificação de Óbitos.

USP - United States Pharmacopeia. 
Comprimento:

$\mathrm{m}$ - metro.

cm - centímetro.

$\mathrm{mm}$ - milímetro.

nm - nanômetro.

Tempo:

$\mathrm{s}-$ segundo.

$\mathrm{m}-$ minuto.

$\mathrm{h}$ - hora.

Massa:

$\mathrm{Kg}$ - quilograma.

g - grama.

dg - decigrama.

$\mathrm{mg}$ - miligrama.

ug - micrograma.

ng - nanograma.

Volume:

1 - litro.

dl - decilitro.

$\mathrm{ml}$ - mililitro.

Temperatura:

${ }^{\circ} \mathrm{C}$ - grau Celsius.

Quantidade de matéria:

mol - mol (massa molecular expressa em gramas).

mmol - milimol.

Normalidade:

Eq - equivalente-grama

$\mathrm{mEq}$ - miliequivalente-grama

Outras unidades:

Unidades King Armstrong - Unidade de medida da fosfatase.

Unidades Wohlgemuth - Unidade de titulação colorimétrica da amilase sérica. 


\section{SUMÁRIO DAS ILUSTRAÇÕES}

Figura 1 - Mecanismo de produção das pegadas.............................................................................. 90

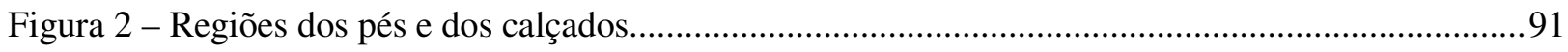

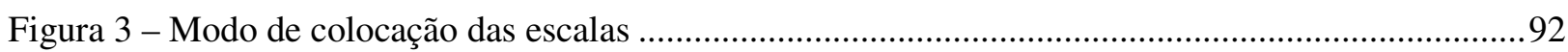

Figura 4 - Prováveis locais de encontro de manchas sangüíneas no corpo ..............................................99

Figura 5 - Prováveis locais de encontro de manchas sangüíneas no local............................................100

Figura 6 - Prováveis locais de encontro de manchas sangüíneas em automóveis ....................................100

Figura 7 - Morfologia das gotas de sangue em queda livre sobre planos horizontais ............................ 102

Figura 8 - Morfologia das gotas de sangue em queda livre sobre planos oblíquos ................................ 103

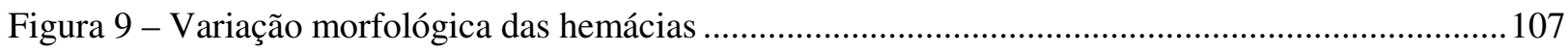

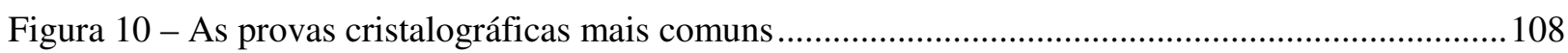

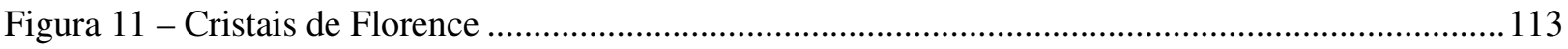

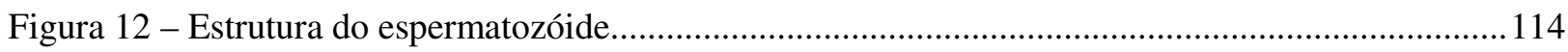

Figura 13 - Morfologia do espermatozóide em diferentes espécies animais......................................... 115

Figura 14 - Elementos microscópicos encontradiços no mecônio..........................................................119

Figura 15 - Elementos microscópicos encontradiços nas fezes........................................................122

Figura 16 - Elementos microscópicos encontradiços no unto sebáceo....................................................130

Figura 17 - Elementos microscópicos encontradiços no líquido amniótico ............................................131

Figura 18 - Fragmento de tecido aderido ao projétil ............................................................................ 140

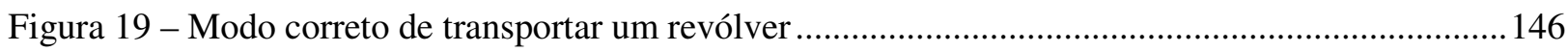

Figura 20 - Modo correto de coletar e acondicionar um projétil ............................................................. 147

Figura 21 - Modos corretos de manusear armas brancas.................................................................... 148

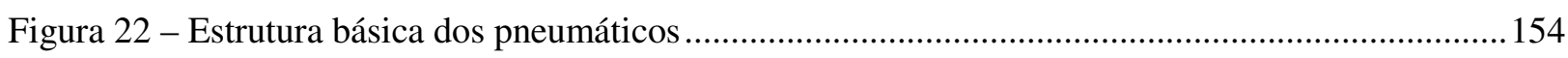

Figura 23 - Variação das marcas de acordo com a forma de incidência da ferramenta ........................... 158

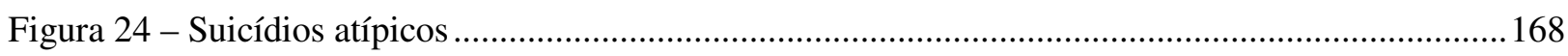

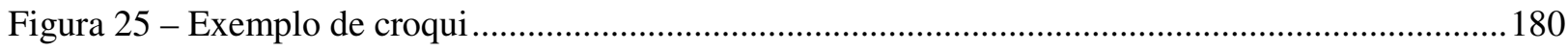

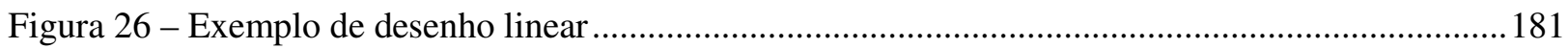

Figura 27 - Exemplo de rebatimento topográfico............................................................................... 182

Figura 28 - Diferença entre a dinâmica do evento e a descrição do ferimento.........................................185

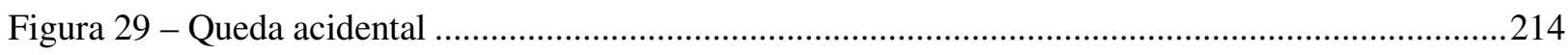

Figura 30 - Hipóteses de suicídio por precipitação sem ou com pequeno impulso inicial......................215

Figura 31 - Suicídio por precipitação com impulso inicial ..................................................................215

Figura 32 - Hipóteses de simulação de suicídio ou de homicídio por precipitação ................................216

Figura 33 - Artefato utilizado para burlar exames antidoping ........................................................238

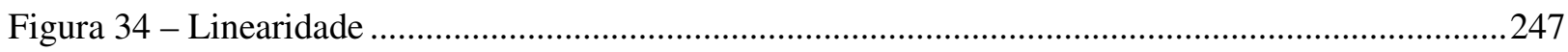

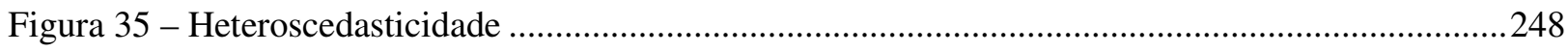

Figura 36 - Formulário padrão do IML - Posição ortostática ............................................................262

Figura 37 - Divergência aparente entre peritos - orientação do disparo ………...................................263

Figura 38 - Divergência aparente entre peritos ................................................................................263

Figura 39 - Divergência aparente entre peritos - orientação e número de disparos .................................264 


\section{SUMÁRIO}

RESUMO

ABSTRACT

ABREVIATURAS E SIGLAS

UNIDADES DE MEDIDA

SUMÁRIO DAS ILUSTRAÇÕES

INTRODUÇÃO

1. CIÊNCIAS FORENSES

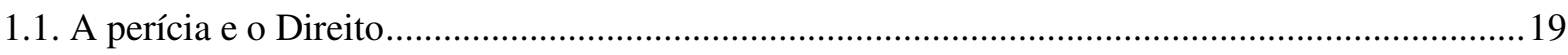

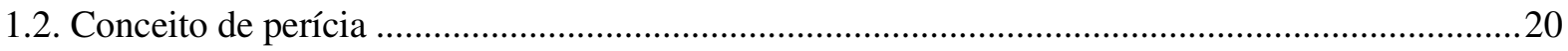

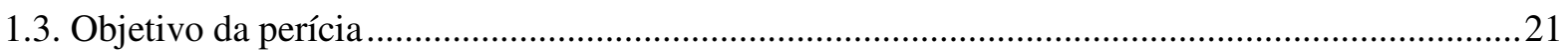

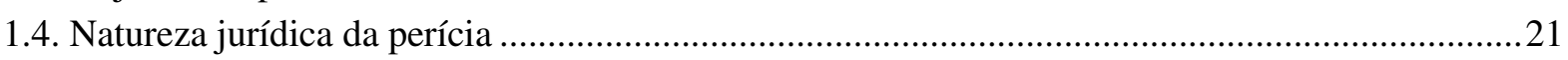

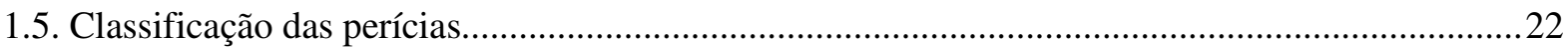

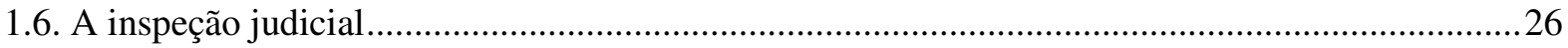

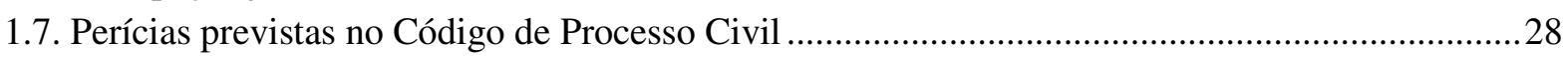

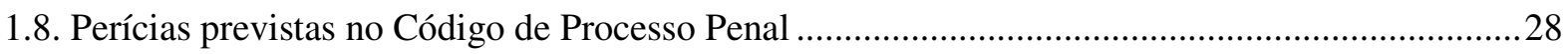

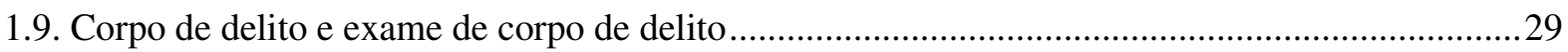

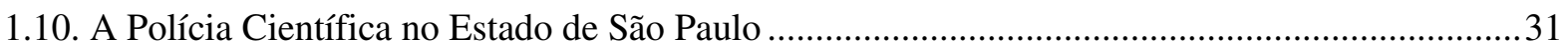

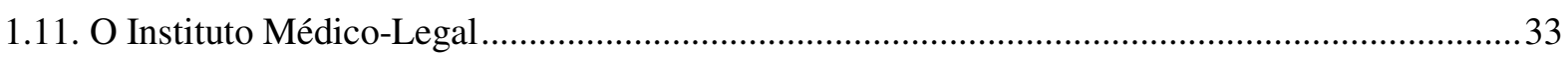

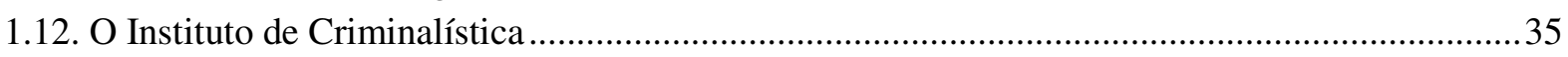

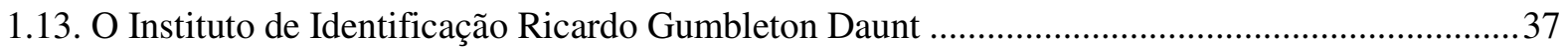

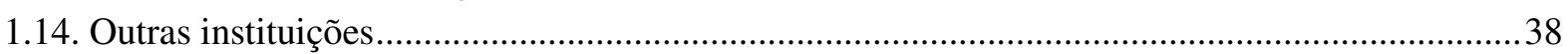

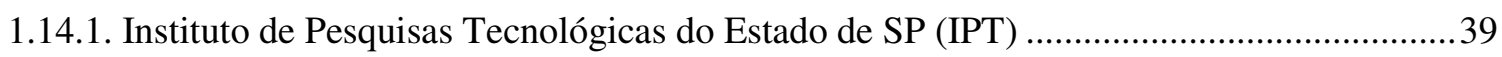

1.14.2. Instituto de Pesquisas Energéticas e Nucleares (IPEN) ...................................................... 39

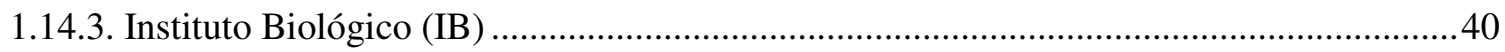

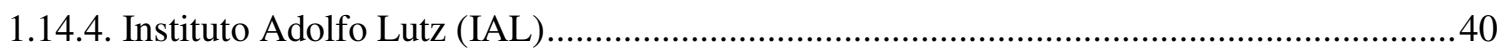

1.14.5. Instituto de Pesos e Medidas do Estado de São Paulo (IPEM) .......................................... 41

1.14.6. Instituto de Medicina Social e Criminologia de SP (IMESC) .............................................42

1.14.7. Companhia de tecnologia de Saneamento Ambiental (CETSB) ......................................... 42

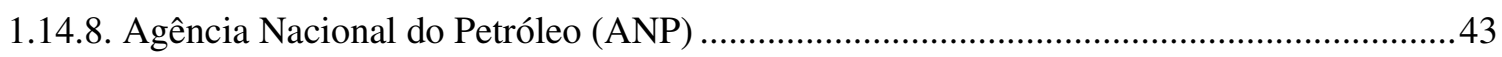

1.14.9. Grupo de Operações Táticas Especiais da Polícia Militar (GATE) ....................................... 43

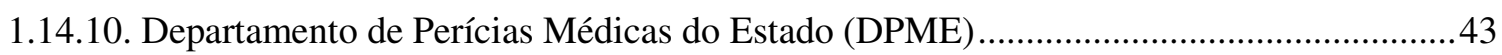

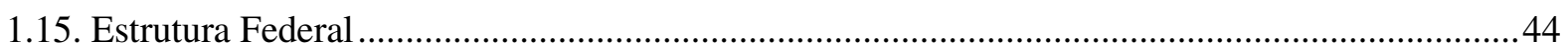

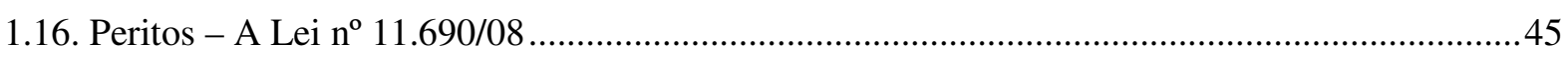

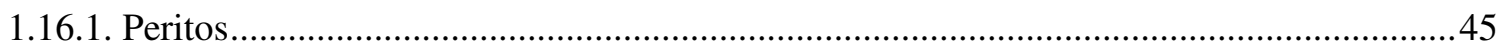

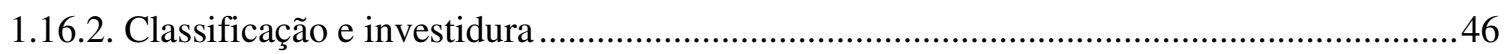

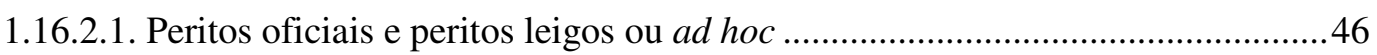

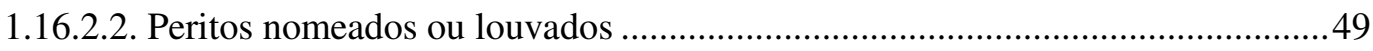

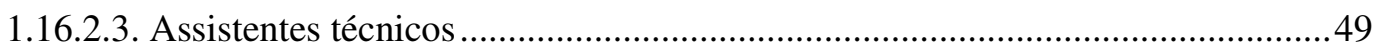

1.16.2.4. Momento de admissão dos assistentes técnicos ...................................................51

1.16.2.5. Modo de atuação dos assistentes técnicos .......................................................53

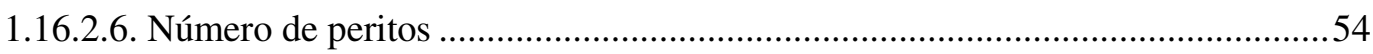

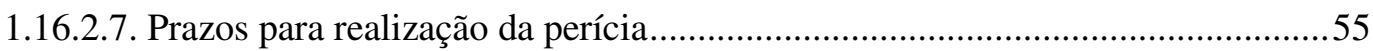




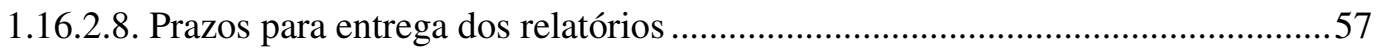

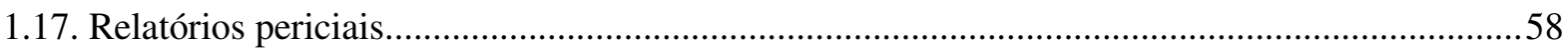

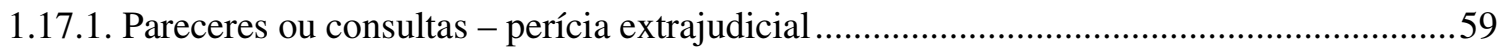

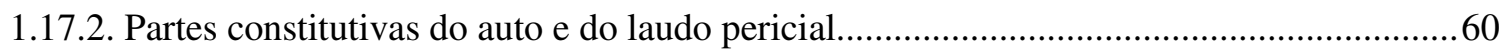

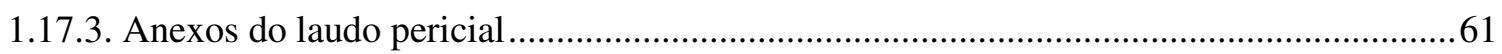

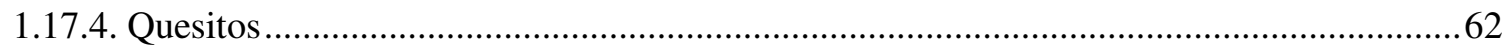

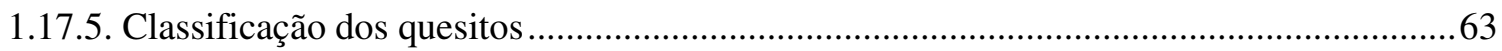

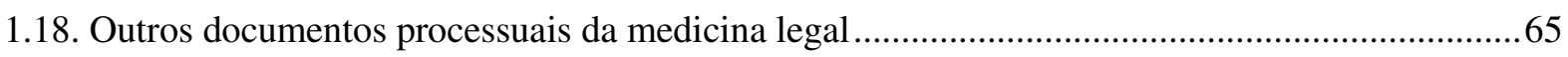

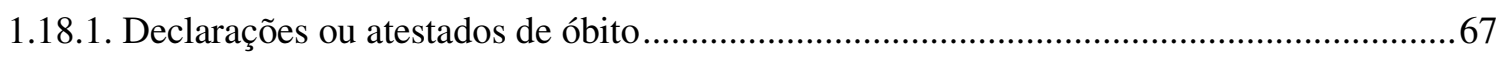

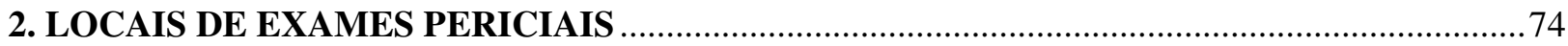

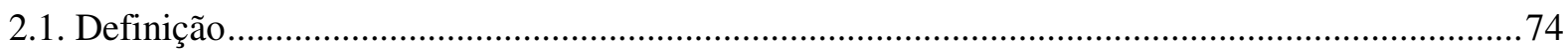

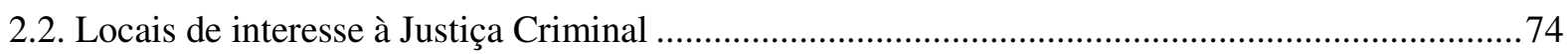

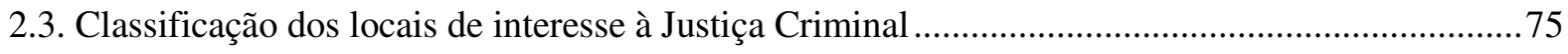

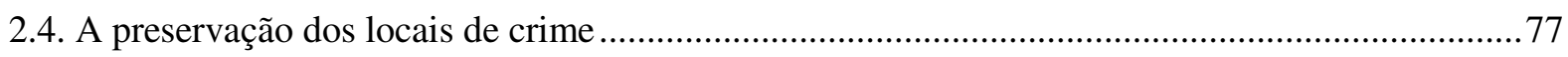

2.5. Indícios, vestígios, circunstâncias e presunções ............................................................................. 78

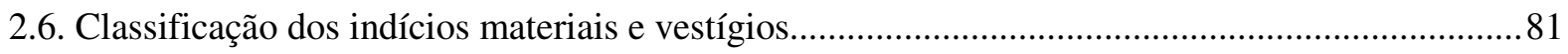

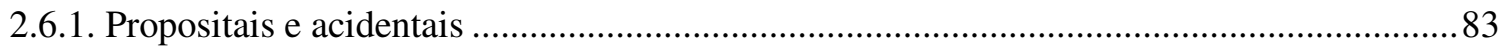

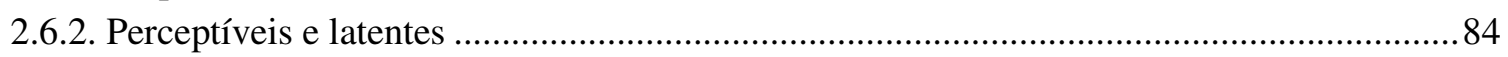

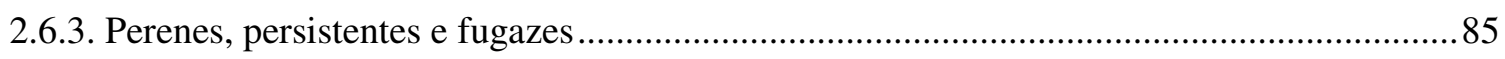

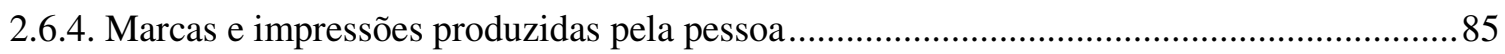

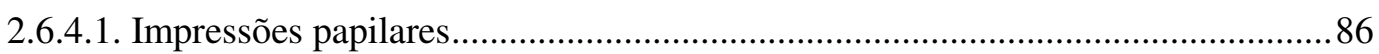

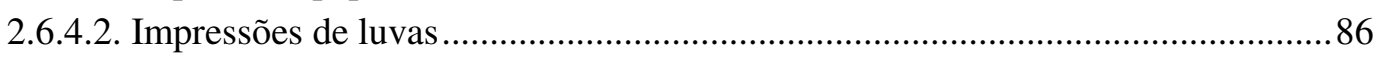

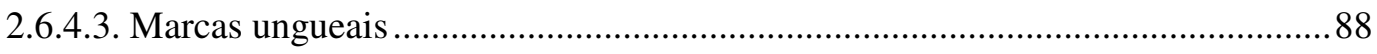

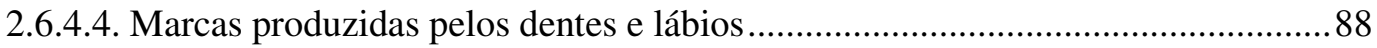

2.6.4.5. Marcas e impressões produzidas pelos pés descalços ou por solados

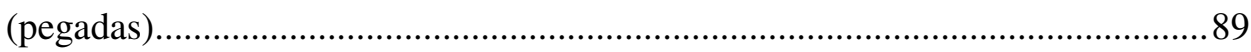

2.6.4.6. Marcas e impressões de partes do corpo ………………………...................92

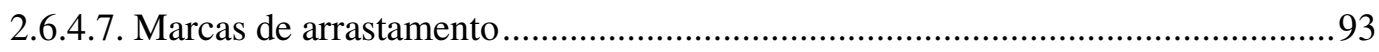

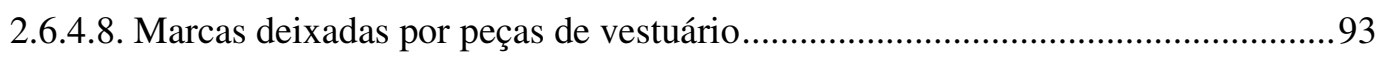

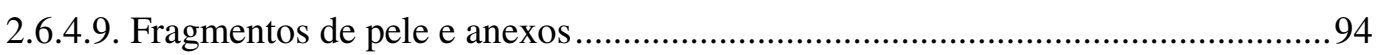

2.6.4.10. Amostras ou manchas de líquidos ou secreções orgânicas................................96

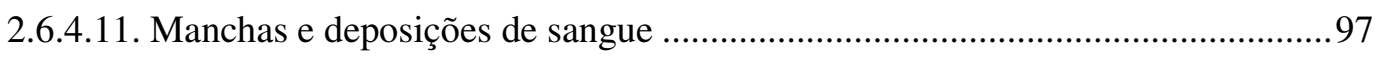

2.6.4.12. O estudo das manchas de sangue no local do fato..............................................97

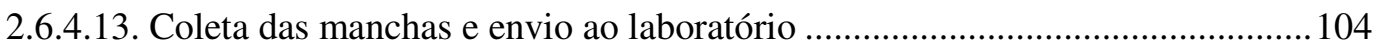

2.6.4.14. O estudo das manchas de sangue no laboratório .............................................104

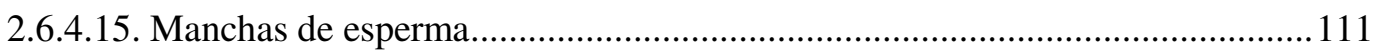

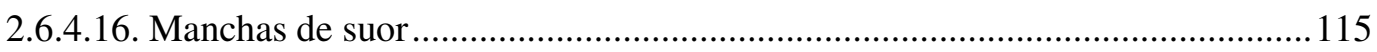

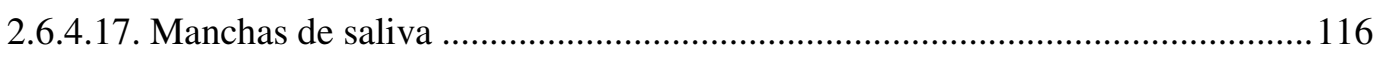

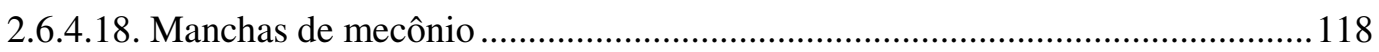

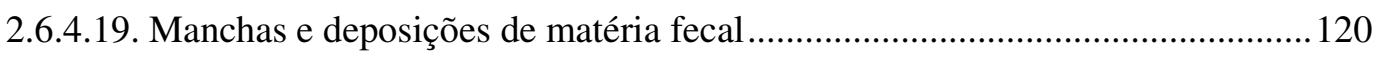

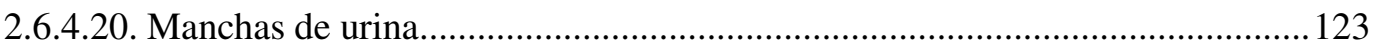

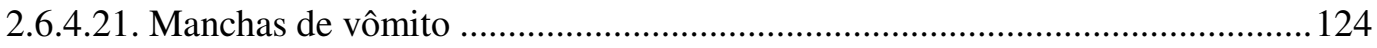

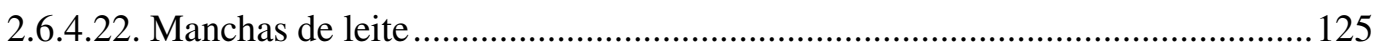

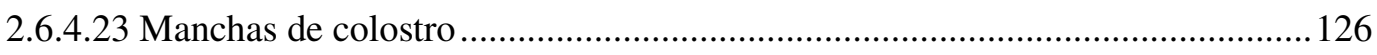

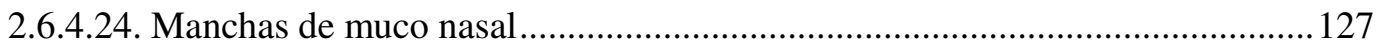




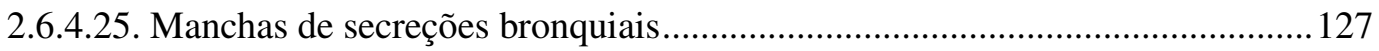

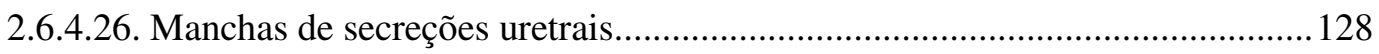

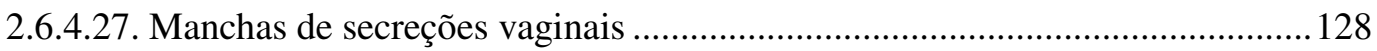

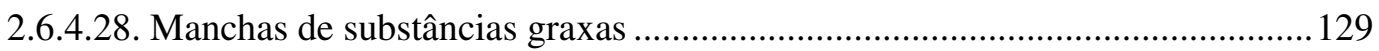

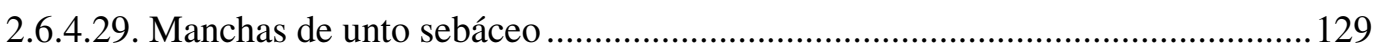

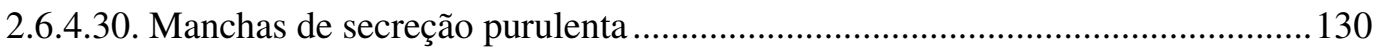

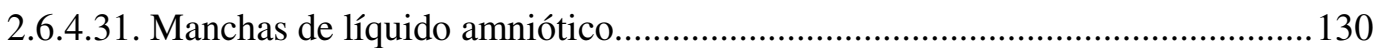

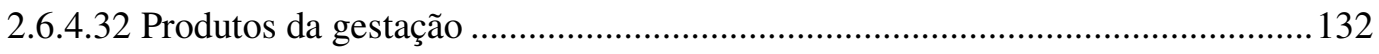

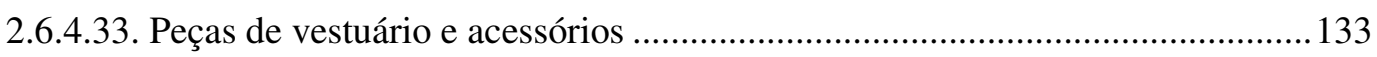

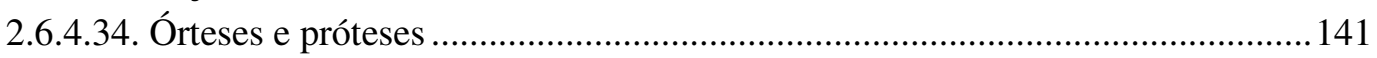

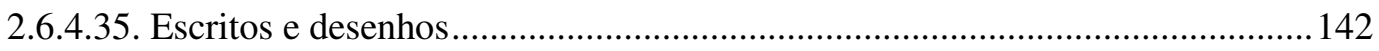

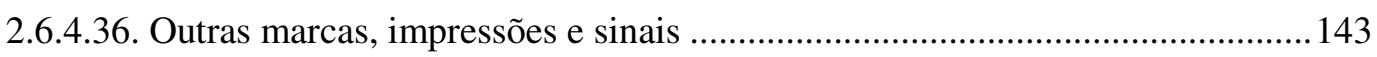

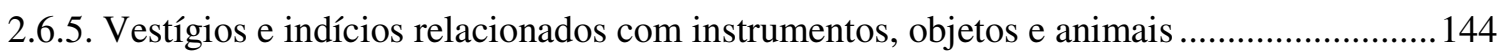

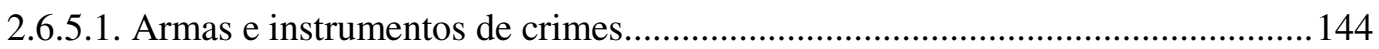

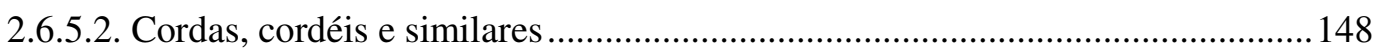

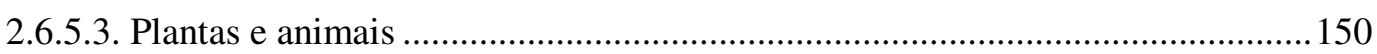

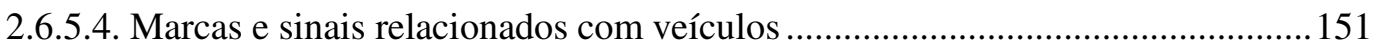

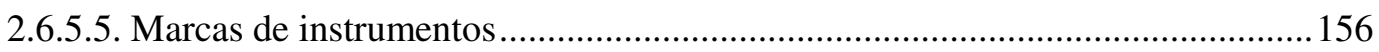

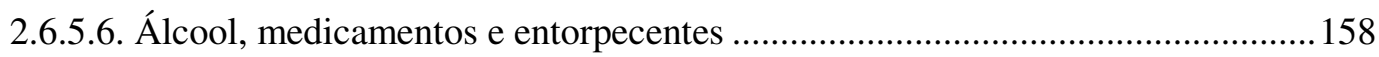

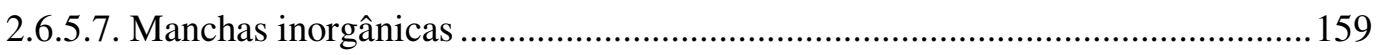

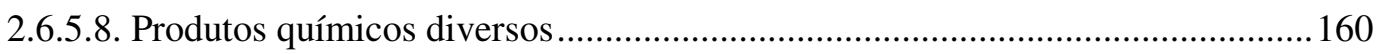

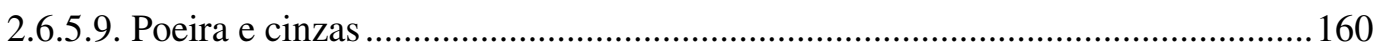

2.6.5.10. Papéis, cartas, livros, documentos, gravações filmes, fotografias e outros .....163

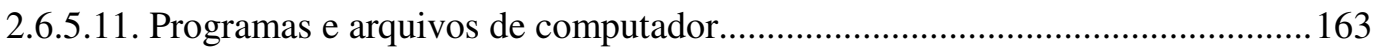

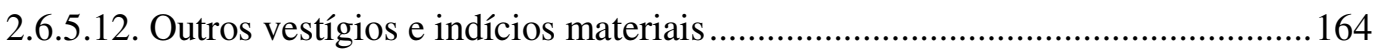

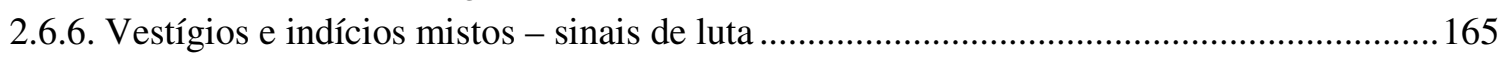

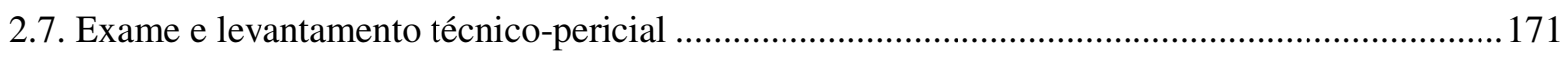

2.7.1. Conceito e finalidades do exame e do levantamento técnico-pericial................................ 171

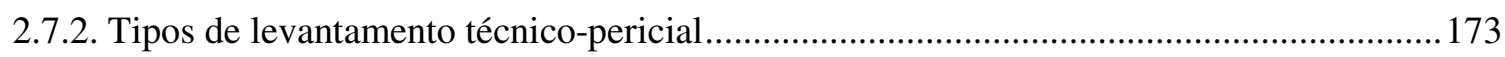

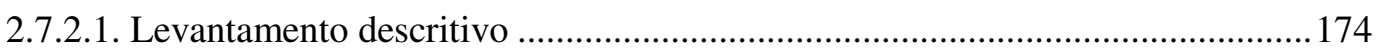

2.7.2.2. Levantamento por fotografia (fotografia judiciária)........................................ 175

2.7.2.3. Levantamento por desenho (topografia judiciária)............................................ 178

2.7.2.4. Levantamento dermatoglífico (ou papiloscópico) ............................................... 183

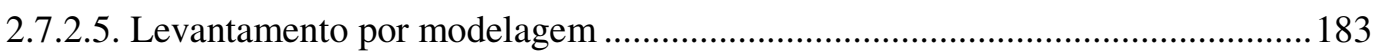

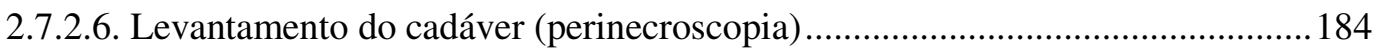

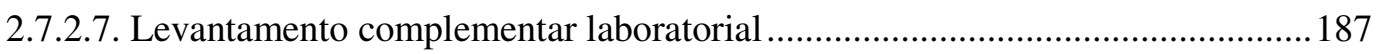

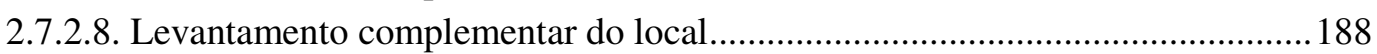

2.7.2.9. Levantamento complementar na pessoa ...........................................................189

2.7.2.10. Levantamento complementar por exumação.................................................190

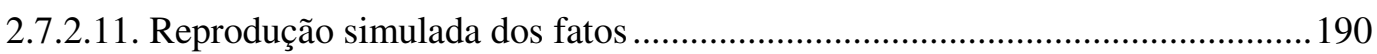

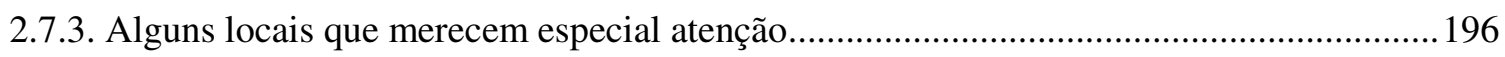

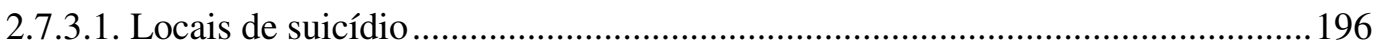

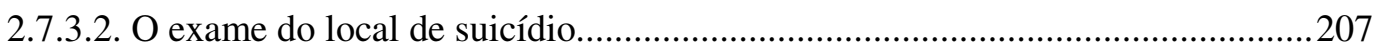

2.7.3.3. Discussão sobre alguns suicídios atípicos ........................................................211

2.7.3.4. Suicídios cometidos com mais de um disparo ou mais de uma arma de fogo...211

2.7.3.5. Locais de morte por precipitação ...................................................................22 
2.7.3.6. Locais de morte a esclarecer ou encontro de cadáver

2.7.3.7. Corpos em adiantado estado de decomposição ................................................217

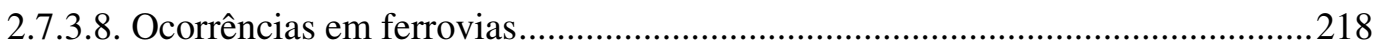

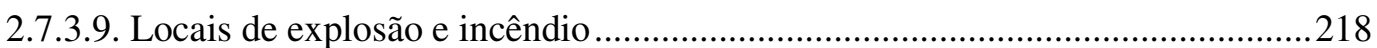

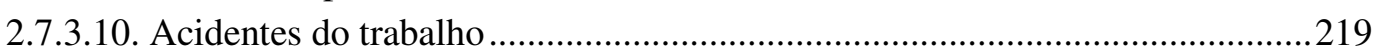

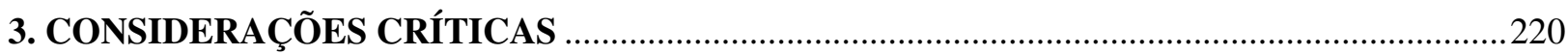

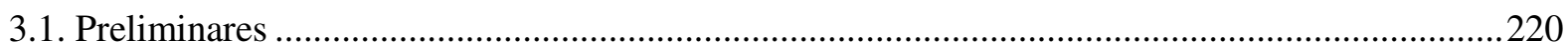

3.2. Estrutura inadequada dos organismos estatais encarregados da produção da prova pericial.......221

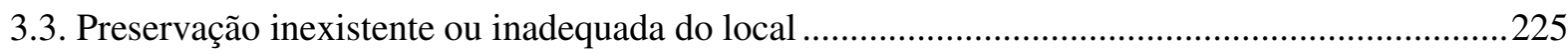

3.4. Despreparo do corpo técnico encarregado da realização dos exames..........................................230

3.4.1. Laudos de constatação, de orientação e tecnicamente conclusivos.....................................231

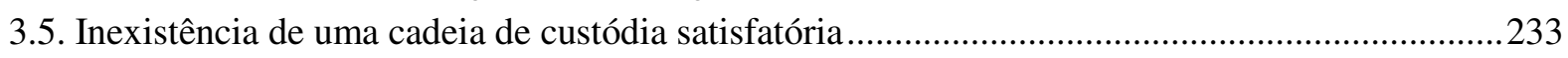

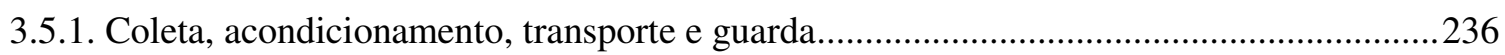

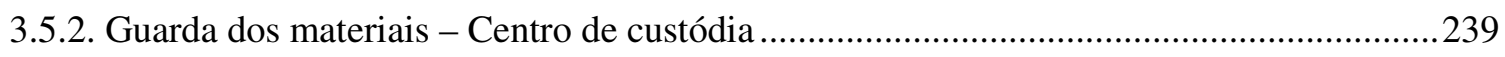

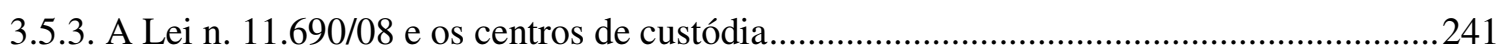

3.6. Ausência de padronização do método e de certificação dos laboratórios envolvidos....................242

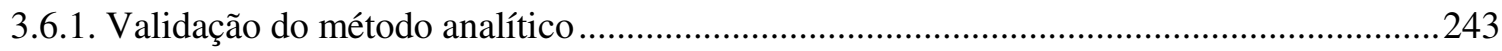

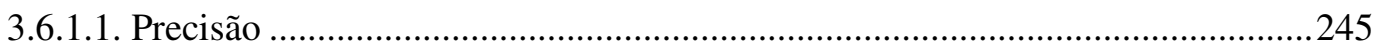

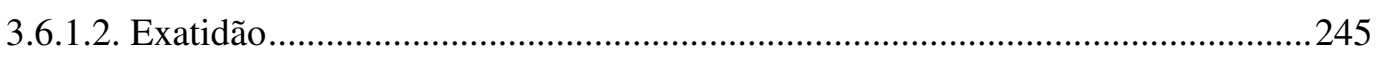

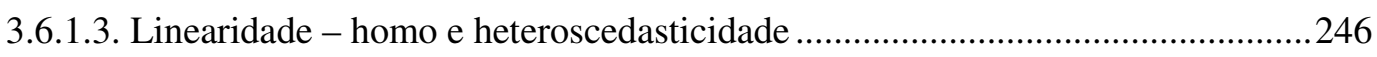

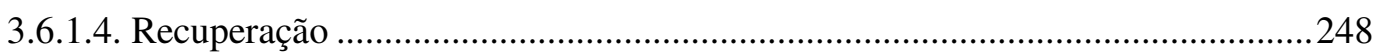

3.6.1.5. Limite de deteç̧ão (LOD) e de quantificação (LOQ) .......................................249

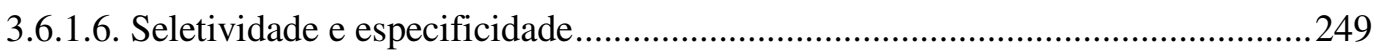

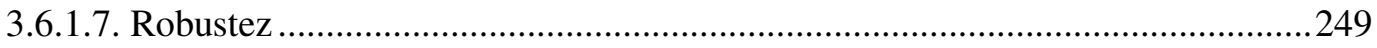

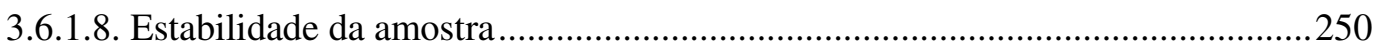

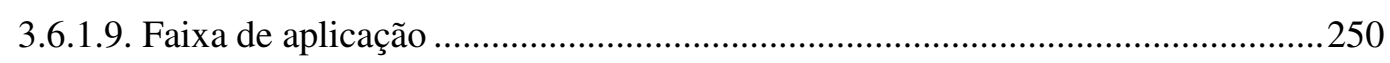

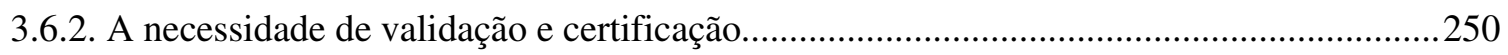

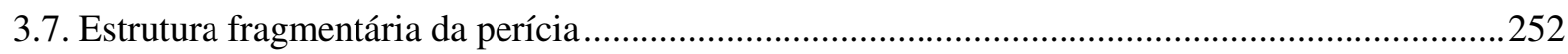

3.8. Despreparo das carreiras jurídicas no que toca a apreciação crítica da prova técnica .................253

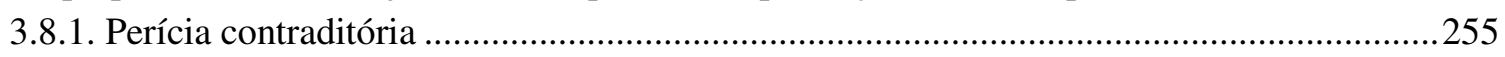

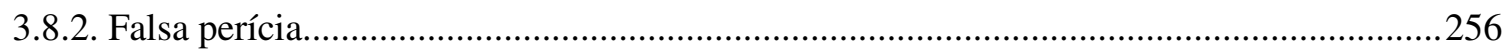

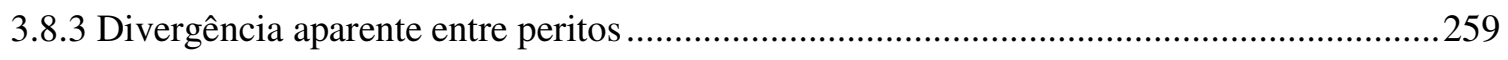

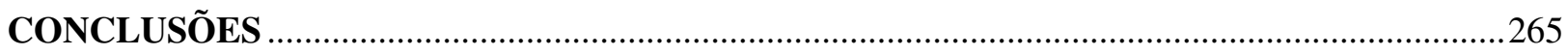

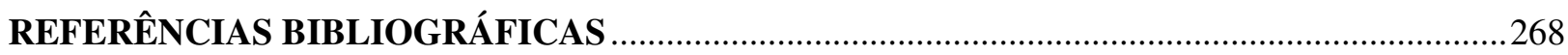




\section{INTRODUÇÃO}

Foi o cão de Nicole, na noite de 12 de junho de 1994, que deu o alarme. Por volta das 10h15min. Os vizinhos ouviram os latidos e avistaram o Akita sujo de sangue, fato que os levou até o portão da residência de número 875 da South Bund Drive, no subúrbio de Brentwood em Los Angeles.

A cena era horripilante. No passeio de entrada do imóvel jaziam os corpos assassinados de Nicole Brown, ex-mulher de Orenthal James Simpson, famoso jogador de futebol americano, e o do amigo dela, Ron Goldman. Ambos estavam cobertos de sangue e apresentavam profundos ferimentos produzidos por instrumento perfurocortante (faca). Nicole estava praticamente decapitada.

Cinco gotas de sangue formavam uma trilha que se afastava dos corpos e apontava na direção da saída dos fundos do imóvel ${ }^{1}$, cujo portão estava manchado de sangue. Quatro dessas gotas estavam localizadas imediatamente à esquerda de pegadas deixadas, também em sangue, pelo solado de um sapato masculino de tamanho 12 (45 pelo sistema brasileiro), mesmo número calçado por O. J. Simpson. Tal constatação indicava que o assassino havia sido ferido do lado esquerdo de seu corpo.

Na manhã seguinte aos crimes, a polícia observou que O. J. Simpson usava uma bandagem no dedo médio da mão esquerda, curativo que encobria um profundo corte em uma das articulações.

Além disso, também foi encontrado sangue no carro de O. J. Simpson, em uma meia, localizada no quarto dele, e em uma luva deixada do lado de fora de sua casa.

Amostras foram extraídas de todas as deposições e manchas encontradas nos locais relacionados com o crime. Uma vez analisadas, o quadro que emergiu parecia demonstrar uma irrefutável ligação entre Simpson e os assassinatos.

Os testes de DNA feitos em todos os cinco pingos e nas manchas do portão traseiro da casa revelaram, sem sombra de dúvida, que o sangue pertencia a O. J. Simpson.

\footnotetext{
${ }^{1}$ PLATT, Richard. Crime scene: the ultimate guide to forensic science. $1^{\text {th }}$ ed. New York: Dorling \& Kindersley, 2003.
} 
O sangue recolhido do automóvel apresentava perfis compatíveis com o de O. J. Simpson e com os de ambas as vítimas. A luva continha os perfis de Nicole e de Ron, e a meia o DNA de Nicole.

Ao ser apontado como possível autor de duplo homicídio, O. J. Simpson desapareceu, depois de deixar com amigos uma carta que anunciava seu desejo de cometer suicídio. Localizado, foi perseguido pela polícia por 96 quilômetros, trancou-se durante horas em seu carro e em seguida entregou-se.

Durante o julgamento a defesa lutou bravamente. Pequenas falhas na coleção de evidências foram habilmente exploradas de maneira a demonstrar uma possível contaminação das amostras. A estratégia da defesa foi a de não apenas tentar desenhar o cenário de uma investigação incompleta e falha, como o de uma investigação em que a polícia poderia ter comprometido a prova técnica pela inobservância de uma correta cadeia de custódia ou plantado evidências de forma desonesta.

A estratégia funcionou e, apesar do esmagador conjunto probatório, O. J. Simpson foi absolvido do duplo homicídio por veredicto proferido em 3 de outubro de $1995^{2}$.

Anos antes, em outro crime, não menos midiático, na madrugada de 9 de agosto de 1969, na residência de número 10.050 da Cielo Drive, Bel Air, também em Los Angeles, a herdeira milionária de uma empresa de café, Abigail Folger, seu namorado, o playboy polonês, Wojciech Frykowski, o conhecido cabeleireiro Jay Sebring e a dona da casa, grávida de oito meses e meio, a atriz Sharon Marie Tate, esposa do cineasta francês Roman Polanski, foram brutalmente assassinados por um grupo de quatro jovens hippies fanáticos, integrado por Charles Watson, Susan Atkins, Patricia Krenwinkel e Linda Kasabian, comandados por seu mentor e guru espiritual Charles Manson.

Os corpos foram encontrados pela governanta Winifred Chapman que, ao avistar a chacina, saiu correndo pela rua, literalmente histérica, gritando por auxílio. Foi socorrida por Jim Asin, um adolescente com 15 anos de idade, que estava aquecendo o motor do carro em uma casa vizinha. Jim acionou a polícia às $08 \mathrm{~h} 33 \mathrm{~min}$. Por volta das $09 \mathrm{~h} 05 \mathrm{~min}$., chegou ao local o patrulheiro Jerry Joe DeRosa, único disponível no momento para atender à ocorrência. Pouco depois chegaram duas outras viaturas, com os policiais Willian T. Whisehunt e Robert Burbridge.

${ }^{2}$ SAFERSTAIN, Richard. Criminalistics: an introduction to forensic science. $9^{\text {th }}$ ed. New Jersey: Prentice Hall, 2007. p. 380. 
Experientes, DeRosa, Whisehunt e Burbridge tomaram todos os cuidados para preservar as evidências que observaram no local. A porta da sala estava parcialmente bloqueada por dois baús antigos. No piso, ao lado dos baús, DeRosa observou um par de óculos com armação de tartaruga. Burbridge observou algo mais: no carpete, à esquerda da entrada, havia duas pequenas peças de madeira, semelhantes a fragmentos de um cabo de revólver partido. Manchas de sangue comprometiam todo o lugar.

Mais tarde, à medida que outros policiais afluiam ao local, a cena do crime era desfigurada.

Os óculos com armação de tartaruga foram inadivertidamente removidos antes da chegada da perícia e colocados sobre uma escrivaninha a dois metros de distância. Os dois fragmentos de cabo de revólver, inicialmente visualizados junto à entrada da sala, estavam agora debaixo de uma cadeira em outro cômodo.

Vários policiais pisavam sobre as deposições de sangue e acabavam por misturar as amostras, desconfigurar as manchas e produzir outras em locais onde antes nada havia. Alterações bastante significativas para uma época em que sequer se cogitava do exame de DNA e a tipagem sangüínea era a análise mais acurada que se podia pretender.

Todas essas inovações e intercorrências foram exploradas no julgamento, mas, felizmente, não foram suficientes para afastar a responsabilidade dos assassinos que, condenados à prisão perpétua, ainda cumprem suas penas ${ }^{3}$.

Em ambos os casos, sucintamente relatados, vemos falhas nos procedimentos de coleta e/ou preservação das evidência físicas, com sérias repercussões na prestação jurisdicional penal, similares às que se repetem diuturnamente no Brasil. Apesar disso, em nosso meio, poucos são os questionamentos que recaem sobre a técnica utilizada ou a idoneidade da prova pericial.

Neste trabalho, pretendemos demonstrar a abrangência da prova pericial, notadamente a partir do levantamento dos locais de interesse à Justiça Penal, apontar seus limites, deficiências e qualidades e sugerir modificações possíveis de maneira a contribuir para o aperfeiçoamento das ciências forenses.

\footnotetext{
${ }^{3}$ BUGLIOSI, Vincent; GENTRY, Curt. Helter Skelter: the true story of the manson murders. New York: W. W. Norton \& Company, Inc., 1994. p. 35.
} 


\section{AS CIÊNCIAS FORENSES}

\subsection{A perícia e o Direito}

Costuma existir certa separação entre os profissionais do Direito e das demais ciências exatas e biológicas, quer porque atuam em ramos absolutamente distintos do conhecimento humano, com métodos e objetos próprios, quer porque se colocam, com freqüência, em situações antagônicas dentro do processo.

Idiossincrasias à parte, é possível afirmar que existem mais similaridades que diferenças entre essas profissões e que há áreas de concentração que demandam ação conjunta no interesse da sociedade.

São médicos, químicos, matemáticos, físicos, engenheiros, psicólogos, sociólogos, filósofos que, juntamente com os juízes, promotores, advogados e demais auxiliares, se irmanam na difícil tarefa de distribuir a Justiça.

Apesar da diversidade de áreas envolvidas e da grande inter-relação entre elas, costuma-se dividir as ciências forenses em três grandes grupos: a medicina legal, a criminalística e a criminologia. Tal conceituação não é correta, pois a expressão ciências forenses é mais ampla e engloba hipóteses não abrangidas pelos ramos mencionados.

Neste trabalho procuraremos fazer uma análise dos capítulos mais importantes da medicina legal e da criminalística, além de ponderações a respeito da apreciação e valoração das chamadas provas técnicas, especialmente nos casos em que o bem jurídico violado se relaciona com a vida, a saúde ou a integridade do ser humano.

O quadro a seguir, adaptado de similar proposto por Calabuig ${ }^{4}$, dá uma pálida noção da abrangência do tema.

${ }^{4}$ CALABUIG, J. A. Gisbert. Medicina legal y toxicologia. 5. ed. Barcelona: Masson, 1998. p. 4. 


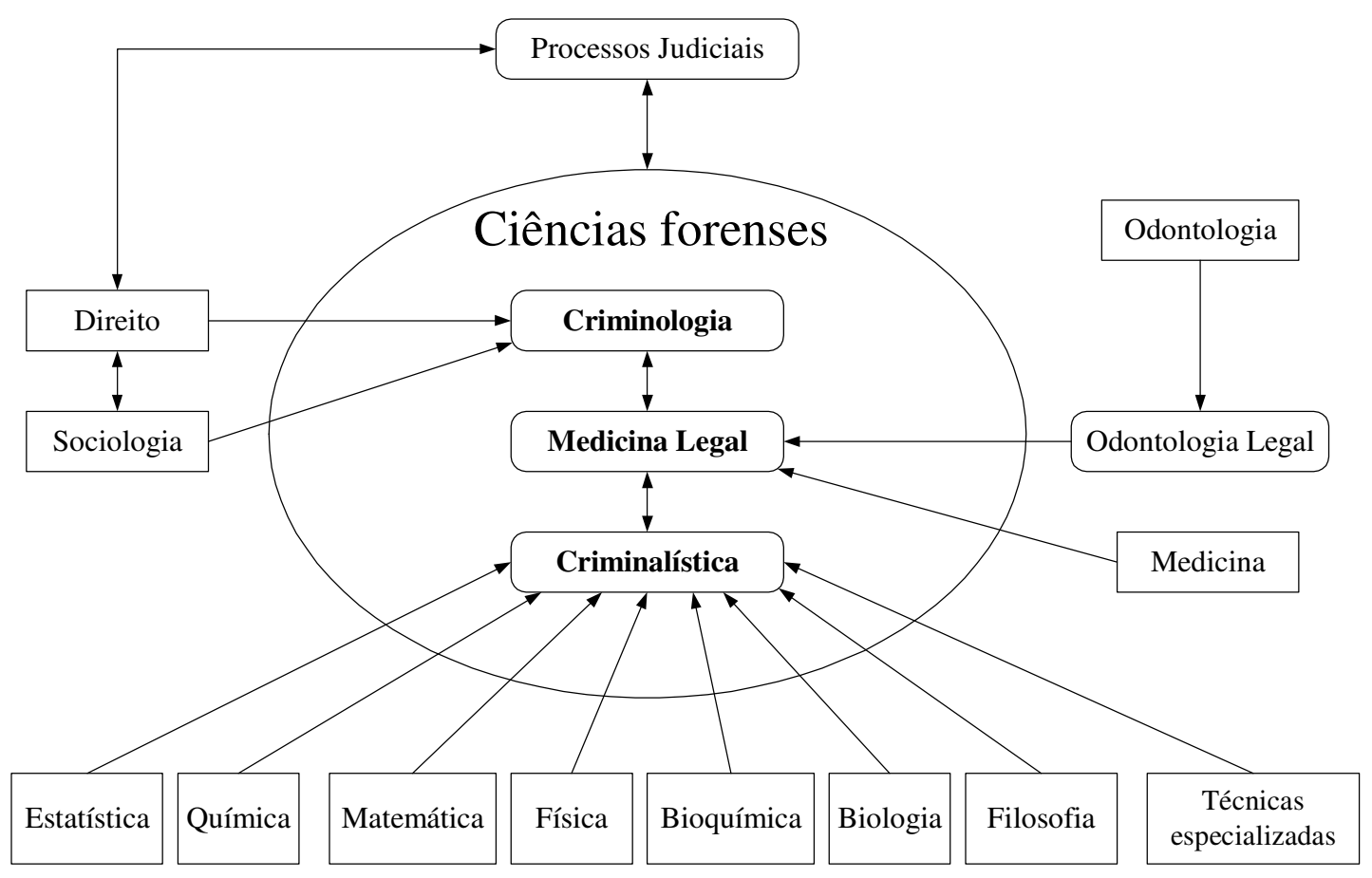

\subsection{Conceito de perícia}

Para Fernando Capez ${ }^{5}$ :

"O termo perícia, originário do latim peritia (habilidade especial), é um meio de prova que consiste em um exame elaborado por pessoa, em regra profissional, dotada de formação e conhecimentos técnicos específicos, acerca de fatos necessários ao deslinde da causa. Trata-se de um juízo de valoração científico, artístico, contábil, avaliatório ou técnico, exercido por especialista, com o propósito de prestar auxílio ao magistrado em questões fora de sua área de conhecimento profissional."

Zarzuela $^{6}$ a define como:

"Modalidade de prova que requer conhecimentos especializados para a sua produção, relativamente à pessoa física, viva ou morta, e à coisa, implicando da apreciação, interpretação e descrição de fatos ou de circunstâncias, de presumível ou evidente interesse jurídico.”

${ }^{5}$ CAPEZ, Fernando. Curso de processo penal. 2. ed. São Paulo: Saraiva, 1998. p. 251.

${ }^{6}$ ZARZUELA, José Lopes; MATUNAGA, Minoru; THOMAZ, Pedro Lourenço. Laudo pericial: aspectos técnicos e jurídicos. 1. ed. São Paulo: Ed. Revista dos Tribunais; Sindicato dos Peritos Criminais do Estado de São Paulo, 2000. p. 337. 
Perícias são, enfim, todos os exames levados a efeito por profissionais da medicina (clínicos, laboratoriais ou necroscópicos) ou de outras áreas do conhecimento humano, destinados a uso como meio de prova judicial. São ensaios que reclamam conhecimentos técnicos, científicos ou artísticos de seu protagonista.

Os espanhóis as denominam de informe especial, os franceses de expertise ou avaliation, os ingleses de expert examination, os alemães, referindo-se ao laudo pericial, usam a expressão sachverständgen gutachten, que literalmente significa parecer de entendido na matéria, assunto ou coisa ${ }^{7}$.

Como as questões levadas a juízo são muito diversas, a natureza da perícia depende do tipo de exame considerado, requerendo um profissional especializado que poderá ou não ser um médico.

Tratando-se de matéria médica, o perito necessariamente deverá ser um médico e o exame produzido uma perícia médica. Cuidando-se de matéria referente às demais especialidades, o indicado poderá ser um engenheiro, um físico, um químico ou outro profissional habilitado, e o exame produzido uma perícia de engenharia, de física, de química ou diversa.

\subsection{Objetivo da perícia}

O objetivo da perícia é a produção de um documento técnico, científico ou artístico, de natureza médico-legal ou criminalística ${ }^{8}$.

\subsection{Natureza jurídica da perícia}

Dentro da teoria do processo, a perícia está classificada como um meio de prova especial, ao qual se concede um valor relativo maior, situando-se em uma posição intermediária entre as provas comuns e a sentença.

Como bem lembra Helio Tornaghi:

\footnotetext{
${ }^{7}$ TORNAGHI, Hélio. Curso de processo penal. 6. ed. São Paulo: Saraiva, 1989. v. 1, p. 312.

${ }^{8}$ ZARZUELA, José Lopes; MATUNAGA, Minoru; THOMAZ, Pedro Lourenço.op. cit., p. 337.
} 
"Se o perito se limitasse a transmitir ao juiz o que apurou com seus conhecimentos técnicos, então a perícia seria realmente apenas um meio de prova, testemunho. Mas tal não se dá: o perito emite juízo sobre o valor dos fatos, externa impressão sobre a possibilidade de terem sido causados por outros acontecimentos e de virem a produzir outros ainda. Considera não apenas a realidade, mas joga também com as probabilidades, com os princípios da experiência (erfahrungssätzen). Entra em conjeturas sobre as relações do fato com outros eventos. Não se atém a relatar ao juiz o que se passou e de que teve conhecimento graças a seu saber científico ou artístico. O que o juiz deseja saber do perito é qual o valor e quais as prováveis conseqüências dos fatos. Não apenas o que ocorreu, mas o que há de vir. O diagnóstico e o prognóstico do perito não podem, de maneira alguma, considerar-se mera prova", concluindo que "a perícia não prova somente, mas também ilumina a prova." 9

Jorge Americano baseia a diferença entre a perícia e a prova testemunhal na forma de aquisição do conhecimento que transmitem ao juízo. Lembra o autor que:

"Na testemunha não há contemporaneidade entre a aquisição e a função jurisdicional. Aquela toma conhecimento dos fatos no momento em que os mesmos se dão, de sorte que os juízos que formula, e as consequiências que induz, ela os faz sob a impressão dessa presença ocasional; há perfeito sincronismo entre o fato que se dá e o conhecimento que a testemunha adquire, mas ela só se investe da função judicial posteriormente, quando arrolada. O perito não. Ele vai conhecer do fato para o fim intencional de instruir a demanda, pelos elementos subseqüentes ao mesmo fato, pelos vestígios." 10

\subsection{Classificação das perícias}

As perícias podem ser classificadas segundo vários critérios. No quadro a seguir indicamos os mais freqüentes, a título de exemplo:

${ }^{9}$ TORNAGHI, Hélio. op. cit., v. 1, p. 313.

${ }^{10}$ AMERICANO, Jorge. Processo civil e comercial no direito brasileiro. São Paulo: Saraiva, 1925. p. 125. 


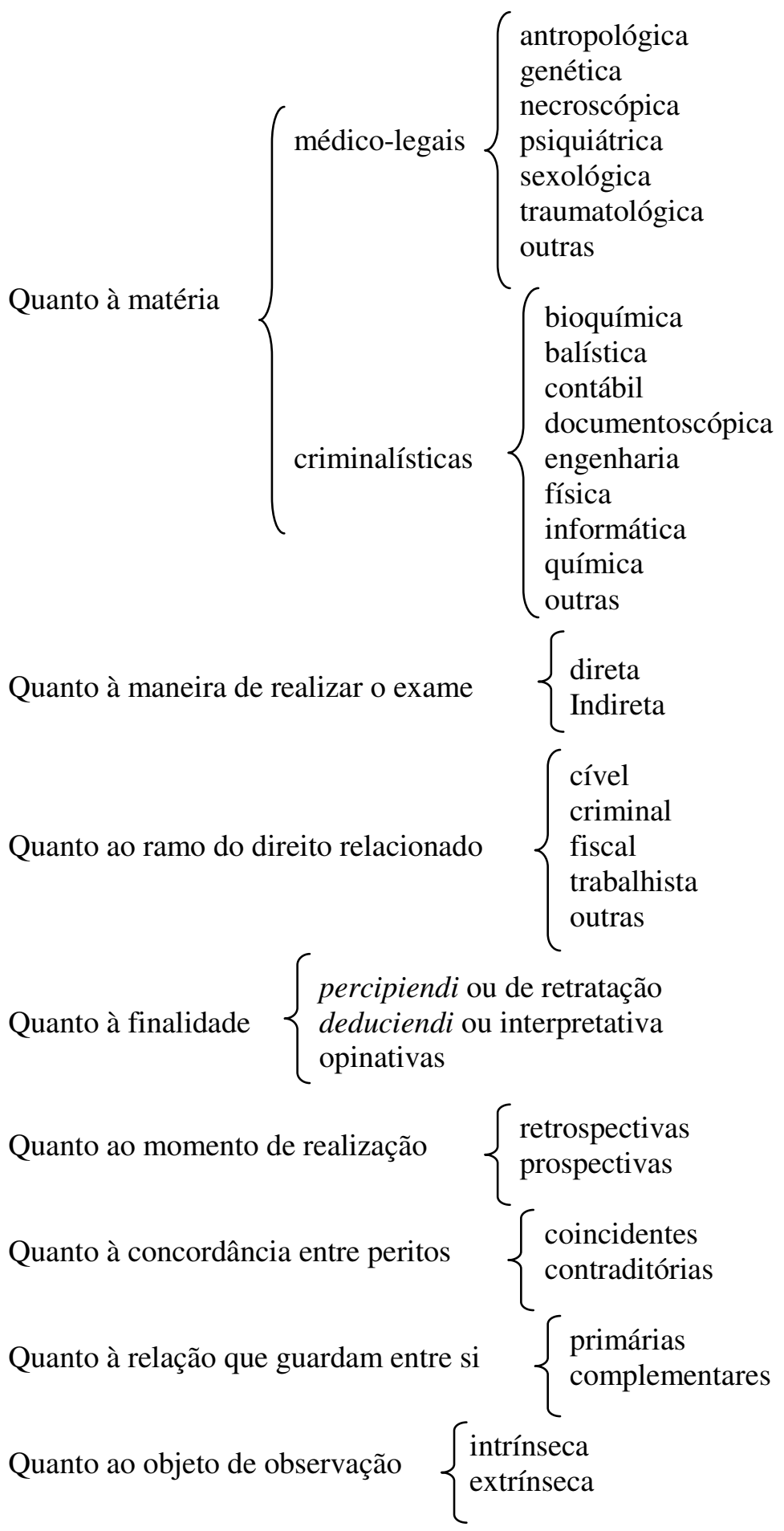

Quanto ao sistema de apreciação da prova pelo magistrado $\quad\left\{\begin{array}{l}\text { vinculatória } \\ \text { liberatória }\end{array}\right.$ 
De acordo com a matéria, as perícias se dividem em médico-legais e criminalísticas (ou não médicas). Desnecessário traçar maiores comentários porque já analisamos os diversos campos que cada uma das ciências engloba.

Quanto à maneira de realizar o trabalho, podem ser diretas ou indiretas.

Na perícia direta o exame é feito objetivamente sobre a coisa ou a pessoa, sempre que o evento tenha deixado vestígios. No caso da medicina legal, por exemplo, será direta quando o médico examinar a própria vítima e indireta quando a análise for efetivada por intermédio de fichas hospitalares ou outros documentos.

O exame indireto não deve ser confundido com o depoimento de testemunhas, que eventualmente poderá suprir a falta do exame de corpo de delito (art. 167 do CPP). Nele, como observa Hélio Tornaghi ${ }^{11}$, "há sempre um juízo de valor feito pelos peritos. Uma coisa é afirmarem as testemunhas que viram tais sintomas, e outra os peritos concluírem, daí, que a causa mortis foi essa ou aquela”.

No que toca ao ramo do direito relacionado, as perícias podem objetivar a elucidação de questões de natureza criminal, cível, trabalhista, tributária e outras, dependendo dos interesses em litígio.

Considerada a finalidade, podem ser de retratação, de interpretação ou opinativas.

Perícia de retratação ou percipiendi é a que tem por objetivo apenas a reprodução pura e simples das impressões colhidas pelo técnico. A maior parte das perícias limita-se à narração detalhada daquilo que foi observado no local, nos instrumentos do crime ou no corpo da vítima, sem que o perito venha a emitir qualquer conclusão específica.

Essa é talvez a modalidade mais simples e comum de exame pericial, principalmente nos levantamentos de locais de crime. O símbolo do Instituto de Criminalística de São Paulo, com o brocardo latino: "visum et repertum", demonstra essa realidade.

Perícia interpretativa ou deduciendi é a que se realiza por meio de uma metodologia científica de análise e interpretação dos fatos ou de suas circunstâncias. Nela, o perito, após analisar todos os elementos colhidos de seu objeto de estudo, apresenta uma conclusão técnica sobre o evento questionado.

\footnotetext{
${ }^{11}$ TORNAGHI, Hélio. op. cit., v. 1, p. 319.
} 
Perícia opinativa é aquela que corresponde a um parecer dos especialistas sobre determinado assunto. As conclusões, no caso, traduzem o entendimento, a opinião dos técnicos sobre determinado tema e não necessariamente uma verdade.

Quanto ao momento de efetivação do exame em relação ao fato analisado, as perícias podem ser retrospectivas ou prospectivas. As primeiras, retrospectivas, constituem exames realizados no presente, mas relacionados com fatos pretéritos, e têm por objetivo a perpetuação dos elementos de prova colhidos (efeitos futuros). Correspondem à maior parte das perícias.

As prospectivas relacionam-se ao exame de situações presentes cujos efeitos deverão ocorrer no futuro, como, por exemplo, o exame de cessação de periculosidade, previsto no art. 775 do Código de Processo Penal.

No que tange à concordância entre os peritos, podem ser coincidentes, quando todos têm a mesma opinião, ou contraditórias, em que os especialistas apresentam conclusões diversas em face do mesmo objeto de estudo ${ }^{12}$.

Consideradas umas em relação às outras, as perícias serão primárias quando corresponderem ao exame inicial e complementares quando surgirem em conseqüência de uma perícia anterior.

Em relação ao objeto de observação, podem ser classificadas em intrínsecas, nos casos em que o objetivo é a comprovação da materialidade da infração penal, e extrínsecas, quando o exame recair sobre elementos que circundam o crime, mas não compõem sua materialidade, como, por exemplo, danos produzidos pelo agente no imóvel antes de tirar a vida da vítima.

Finalmente, em relação à possibilidade de livre apreciação da prova pelo magistrado, dividem-se em vinculatórias, nas hipóteses em que o juiz está adstrito às conclusões do laudo, e liberatórias, em que o julgador pode ou não aceitar os resultados do perito, baseado em seu livre convencimento. Esta última foi a posição adotada pela nossa legislação processual (art. 182 do CPP, art. 326 do CPPM e art. 436 do CPC).

CPP

Art. 182. O juiz não ficará adstrito ao laudo, podendo aceitá-lo ou rejeitálo, no todo ou em parte.

CPPM

${ }^{12}$ Ver item 3.8.2: "Falsa perícia". 
Art. 326. O juiz não ficará adstrito ao laudo, podendo aceitá-lo ou rejeitálo, no todo ou em parte

$\mathrm{CPC}$

Art. 436. O juiz não está adstrito ao laudo pericial, podendo formar a sua convicção com outros elementos ou fatos provados nos autos.

\subsection{A inspeção judicial}

Inspeção judicial é uma forma de vistoria feita pelo próprio juiz para verificação de um determinado fato relacionado com a lide.

Afonso Fraga define o instituto como a "inspeção ocular do juiz sobre o objeto da contenda (lugar ou coisa que versa a demanda) com o auxílio somente do pessoal do foro, escrivão, oficial de justiça, partes ou seus procuradores" "13 (art. 440 do CPC).

Para Humberto Theodoro Júnior "é o meio de prova que consiste na percepção sensorial direta do juiz sobre qualidades ou circunstâncias corpóreas ou coisas relacionadas com o litígio"14.

A inspeção judicial pode ter por objeto:

a) pessoas - que integram ou não os pólos processuais, para verificar seu estado de saúde ou condições de vida ou trabalho;

b) coisas - imóveis ou mesmo móveis que, pela sua peculiar condição, não possam ser levadas até o magistrado; e

c) lugares - quando a presença do juiz for importante para esclarecer fatos que importarão na decisão da causa, por exemplo, a condição de visibilidade de uma via pública onde ocorreu acidente em trânsito.

Embora não possa ser classificada como perícia propriamente dita, o Código de Processo Civil faculta ao magistrado a assistência de um ou mais peritos (art. 441 do CPC). A verificação dos fatos é obra do juiz, que pode contar com a colaboração, necessária ou conveniente, dos especialistas.

\footnotetext{
${ }^{13}$ Instituições do Processo Civil Brasileiro, 1940, vol. II, p. 568, apud MARQUES, José Frederico. Instituições de direito processual civil. Campinas, SP: Millennium, 1999. p. 427.

${ }^{14}$ THEODORO JÚNIOR, Humberto. Curso de direito processual civil: teoria geral do direito processual civil e processo de conhecimento. 18. ed. Rio de Janeiro: Forense, 1996. v. 1, p. 483.
} 
Se cumulada com perícia, constitui elemento para apreciação do laudo pelo próprio juiz que deve mencioná-la com todos os pormenores do que observou para que, em caso de recurso, possa ser considerada pela instância superior.

Ensina Moacyr Amaral Santos que:

"O que caracteriza a inspeção judicial, distinguindo-a da perícia, é que naquela o próprio juiz colhe diretamente as informações ou observações das pessoas, coisas ou lugares como objeto de suas observações, enquanto que na perícia essas observações são colhidas por pessoas entendidas, que a transmitem por meio de um relatório." 15

As hipóteses de cabimento estão descritas no art. 442 do CPC. Da diligência poderá ser lavrado um auto circunstanciado instruído ou não com desenhos, gráficos ou fotografias (art. 443 do CPC).

$\mathrm{CPC}$

Art. 440. O juiz, de ofício ou a requerimento da parte, pode, em qualquer fase do processo, inspecionar pessoas ou coisas, a fim de se esclarecer sobre fato, que interesse à decisão da causa.

Art. 441. Ao realizar a inspeção direta, o juiz poderá ser assistido de um ou mais peritos.

Art. 442. O juiz irá ao local, onde se encontre a pessoa ou coisa, quando:

I - julgar necessário para a melhor verificação ou interpretação dos fatos que deva observar;

II - a coisa não puder ser apresentada em juízo, sem consideráveis despesas ou graves dificuldades;

III - determinar a reconstituição dos fatos.

Parágrafo único. As partes têm sempre direito a assistir à inspeção, prestando esclarecimentos e fazendo observações que reputem de interesse para a causa.

Art. 443. Concluída a diligência, o juiz mandará lavrar auto circunstanciado, mencionando nele tudo quanto for útil ao julgamento da causa.

Parágrafo único. O auto poderá ser instruído com desenho, gráfico ou fotografia.

\footnotetext{
${ }^{15}$ SANTOS, Moacyr Amaral. Comentários ao Código de Processo Civil: artigos 332 a 475. 6. ed. Rio de
} Janeiro: Forense, 1994. v. 4, p. 449. 


\subsection{Perícias previstas no Código de Processo Civil}

O Código de Processo Civil elenca, basicamente, três formas de perícias: exame, vistoria e avaliação.

$\mathrm{CPC}$

Art. 420. A prova pericial consiste em exame, vistoria ou avaliação.

Parágrafo único. O juiz indeferirá a perícia quando:

I - a prova do fato não depender do conhecimento especial de técnico;

II - for desnecessária em vista de outras provas produzidas;

III - a verificação for impraticável.

Exame é a inspeção realizada por peritos para certificar a existência de algum fato ou circunstância de importância para a solução da lide. O exame pode recair sobre móveis, semoventes, documentos ou pessoas.

Vistoria é a perícia realizada em bens imóveis.

Avaliação é o exame pericial que tem por objetivo a determinação do valor monetário de alguma coisa ou obrigação. Se o valor a ser apurado for o de um serviço ou implicar na realização de cálculo abstrato de indenização, o Código de Processo Civil utiliza o termo arbitramento.

\subsection{Perícias previstas no Código de Processo Penal}

No Código de Processo Penal temos de diferenciar as perícias médico-legais e as criminalísticas.

Perícias médico-legais:

- Incidente de insanidade mental - art. 149 e seguintes do CPP;

- Autópsia - art. 162 do CPP;

- Exame cadavérico - art. 163 do CPP;

- Exumação - art. 163 do CPP; 
- Identificação de cadáver exumado - art. 166 do CPP;

- Lesões corporais - art. 168 do CPP;

- Médico-legais de laboratório - art. 170 do CPP; e

- Exame de cessação de periculosidade - art. 715, 775 e 777 do CPP.

Perícias criminalísticas:

- Reprodução simulada dos fatos - art. $7^{\circ}$ do CPP;

- Exame de corpo de delito - art. 158 do CPP;

- Perinecroscopia - arts. 164 e 165 do CPP;

- Criminalísticas de laboratório - art. 170 do CPP;

- Exames em locais de crimes contra o patrimônio - art. 171 do CPP;

- Perícias em locais de incêndio - art. 173 do CPP;

- Perícias em documentos - art. 174 do CPP;

- Perícias em instrumentos do crime - art. 175 do CPP; e

- Perícia relacionada com a busca e apreensão - art. 527 do CPP.

Os dispositivos legais relacionados com as perícias em espécie serão analisados, oportunamente e, quando necessário, em cada caso.

\subsection{Corpo de delito e exame de corpo de delito}

Algumas infrações penais deixam vestígios (delita facti permanentis) e outras não (delita facti transeuntis).

Crimes como a injúria verbal (art. 140 do CP) ou o desacato (art. 331 do CP), nada deixam de material que possa ser analisado e consubstanciado em um trabalho pericial, devendo ser constatados por outros meios de prova.

Todavia, delitos, como o homicídio (art. 121 do $\mathrm{CP}$ ) ou a maioria dos crimes patrimoniais, provocam modificações sensíveis no mundo real que podem ser percebidas 
por nossos sentidos ou por aparelhos especiais. Nesses casos é necessária a realização do exame de corpo de delito, cujo resultado será posteriormente apresentado sob a forma de relatório pericial.

Tourinho Filho ${ }^{16}$ lembra que:

"Quando se fala em corpo de delito a primeira idéia que se tem é a do corpo da vítima. Nada mais errado. Corpo de delito ou corpus delicti, ou ainda corpus criminis, é o conjunto dos vestígios materiais deixados pelo crime. Assim o exame de corpo de delito pode ser feito num cadáver, numa pessoa viva, numa janela, num quadro, num documento."

Hélio Tornagui ${ }^{17}$ ensina que:

"Corpo de delito é tudo quanto pode ser usado como prova material do crime: o objeto físico da ação criminosa (p. ex., o corpo lesado), os instrumentos do crime, o produto da infração, os efeitos que caem sob os sentidos, isto é, podem ser vistos, ouvidos, tocados, cheirados, degustados."

Para Zarzuela $^{18}$, a expressão corpo de delito indica:

"A somatória de elementos vestigiais encontradiços nos locais de fato, nos instrumentos relacionados com a prática de uma infração penal, no exame das peças ou na pessoa física, viva ou morta, deixados pelo sujeito ativo da infração penal, que serão apreciados, interpretados e descritos em laudo pericial".

Distingue-se, assim, o corpo de delito, que é, nas palavras de Fernando Capez ${ }^{19}$, "o próprio crime em sua tipicidade", do exame de corpo de delito, expressão que abrange todos os exames realizados no local dos fatos, instrumentos relacionados e pessoas envolvidas.

O exame de corpo de delito, nas infrações que deixam vestígio, é obrigatório (art. 158 do $\mathrm{CPP}$ ). As demais perícias requeridas pelas partes podem ser indeferidas, se não forem absolutamente necessárias ao esclarecimento do feito (art. 184 do CPP).

\footnotetext{
${ }^{16}$ TOURINHO FILHO, Fernando da Costa. Processo penal. 10. ed. São Paulo: Saraiva, 1987. v. 4, p. 220.

${ }^{17}$ TORNAGHI, Hélio. op. cit., v. 1, p. 318.

${ }^{18}$ Conceito proferido em aula ministrada no curso de formação para peritos criminais, na Academia da Polícia do Estado de São Paulo, em 1981.

${ }^{19}$ CAPEZ, Fernando. op. cit., p. 254.
} 


\section{CPP}

Art. 158. Quando a infração deixar vestígios, será indispensável o exame de corpo de delito, direto ou indireto, não podendo supri-lo a confissão do acusado.

Art. 184. Salvo o caso de exame de corpo de delito, o juiz ou a autoridade policial negará a perícia requerida pelas partes, quando não for necessária ao esclarecimento da verdade.

O Código de Processo Penal é expresso em afirmar que configura nulidade a ausência do exame de corpo de delito nas infrações que deixam vestígio, ressalvada a impossibilidade pelo seu desaparecimento (art. 564, III, b, do CPP $)^{20}$.

No processo civil, embora não exista disposição expressa, a ausência da perícia pode levar à nulidade do feito por cerceamento de defesa.

\subsection{A Polícia Científica no Estado de São Paulo}

No Estado de São Paulo, a chamada Polícia Científica, antiga Polícia Técnica, estruturava-se segundo o quadro a seguir:

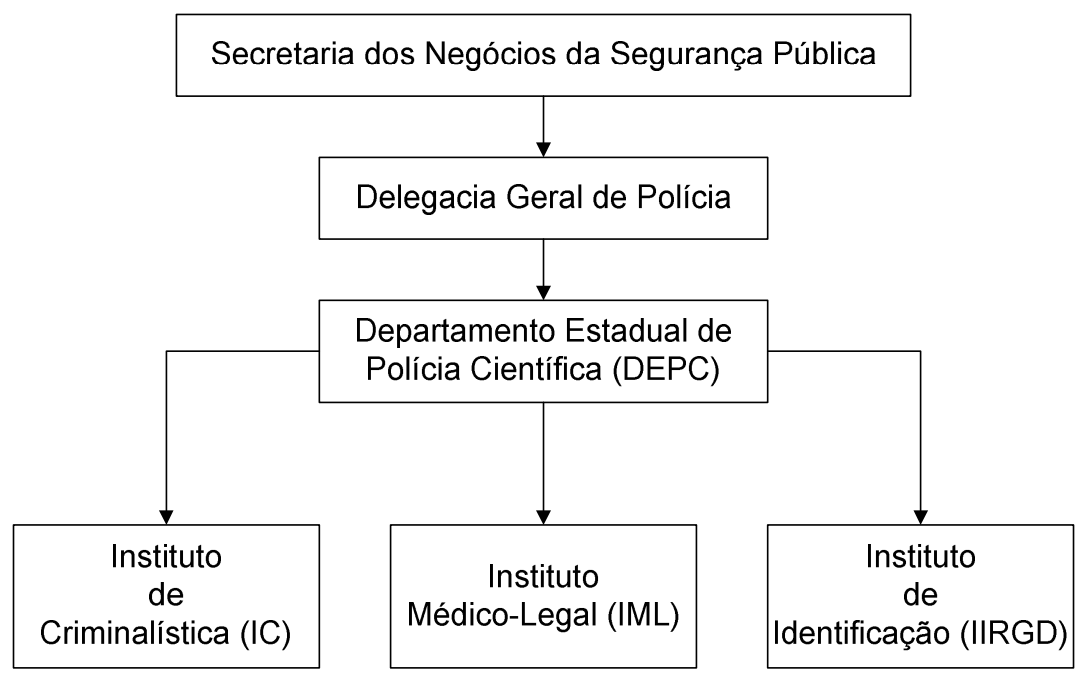

Essa disposição vigorou durante um longo período. A principal crítica que se fazia era a de que órgãos eminentemente técnicos, como o Instituto de Criminalística e o

\footnotetext{
${ }^{20}$ No processo penal, salvo o caso de exame de corpo de delito, o juiz ou a autoridade policial pode negar a realização da perícia requerida pelas partes, quando não for necessária ao esclarecimento da verdade (art. 184 do PP).
} 
Instituto Médico-Legal, não deveriam ser dirigidos por delegados de polícia de carreira, pessoas que, embora com conhecimento jurídico e competência administrativa inquestionáveis, não possuíam o respaldo técnico necessário.

Estas ponderações levaram o legislador a editar a Lei Complementar Estadual $\mathrm{n}^{\circ}$ 756, de 27 de julho de 1994, criando a Superintendência da Polícia Técnico-Científica (SPTC), que alterava significativamente a estrutura anterior.

Apesar de criada no papel, somente quatro anos depois, por iniciativa do Governador Mário Covas, através do Decreto Estadual no 42.847, de 09 de fevereiro de 1998, foi efetivamente implantada.

Ligada diretamente ao Gabinete do Secretário da Segurança Pública e dirigida, alternadamente, por peritos criminais e médicos-legistas, para um período de dois anos, a Superintendência da Polícia Técnico-Científica tem por finalidades ${ }^{21}$ :

I. - coordenar e supervisionar os trabalhos de pesquisas nos campos da criminalística e da medicina legal;

II. - proceder a estudos técnicos no âmbito de suas atividades específicas;

III. - prestar orientação técnica às unidades subordinadas;

IV. - manter intercâmbio com entidades ligadas às áreas científicas correspondentes;

V. - exercer as atividades inerentes aos sistemas de administração geral; e

VI. - zelar pela regularidade das atividades exercidas nas unidades subordinadas.

Pela nova estrutura, o antigo Departamento Estadual de Polícia Científica (DEPC) passou a denominar-se Departamento de Identificação e Registros Diversos (DIRD), ao qual ficaram subordinados o Instituto de Identificação Ricardo Gumbleton Daunt (IIRGD) e o Departamento de Produtos Controlados (DPC). Lamentavelmente, por razões puramente políticas, o IIRGD não ficou subordinado à Superintendência, já que sua função é eminentemente técnica.

O quadro mostra a estrutura atual da Polícia Científica no Estado de São Paulo:

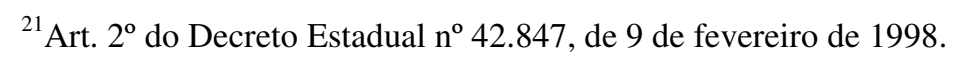




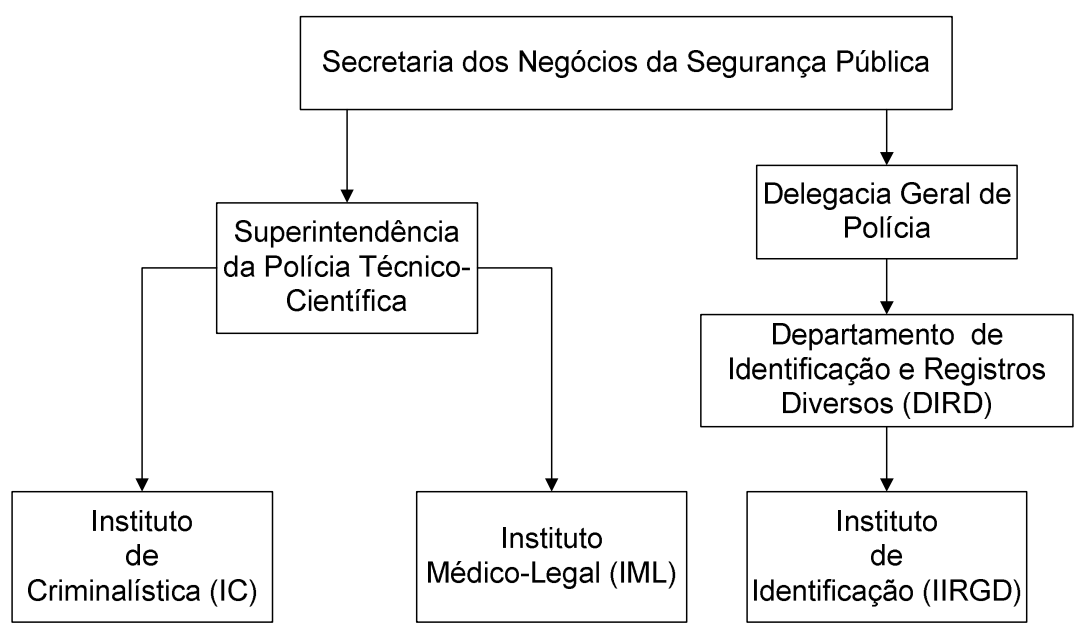

A iniciativa governamental constituiu inegável avanço legislativo. Inicialmente, porque é razoável e desejável que órgãos técnicos sejam dirigidos por aqueles que detêm conhecimento específico na área de atuação. Em segundo lugar, porque as atividades da Polícia Científica apresentam peculiaridades que as distinguem da função básica de investigação, afeta à Polícia Judiciária e, finalmente, porque, em não raras ocasiões, os próprios membros das Polícias Civil e Militar são alvo de apuração, existindo maior credibilidade pública, até em benefício do próprio averiguado, quando os exames periciais são elaborados por organismos desvinculados da atividade policial propriamente dita.

\subsection{O Instituto Médico-Legal}

O Instituto Médico-Legal (IML) tem por finalidade a elaboração das perícias médico-legais e toxicológicas.

Aos médicos-legistas estão afetas as necropsias, exumações e demais exames na pessoa humana. Os exames toxicológicos e laboratoriais relacionados, embora realizados no IML, não são feitos por médicos-legistas, mas por peritos criminais ali designados.

Com a criação da Superintendência, a estrutura do IML ficou sensivelmente alterada, passando a apresentar a seguinte disposição ${ }^{22}$ :

\footnotetext{
${ }^{22}$ Baseado nas atribuições estabelecidas pelo Decreto Estadual no 48.009, de 11 de agosto de 2003.
} 


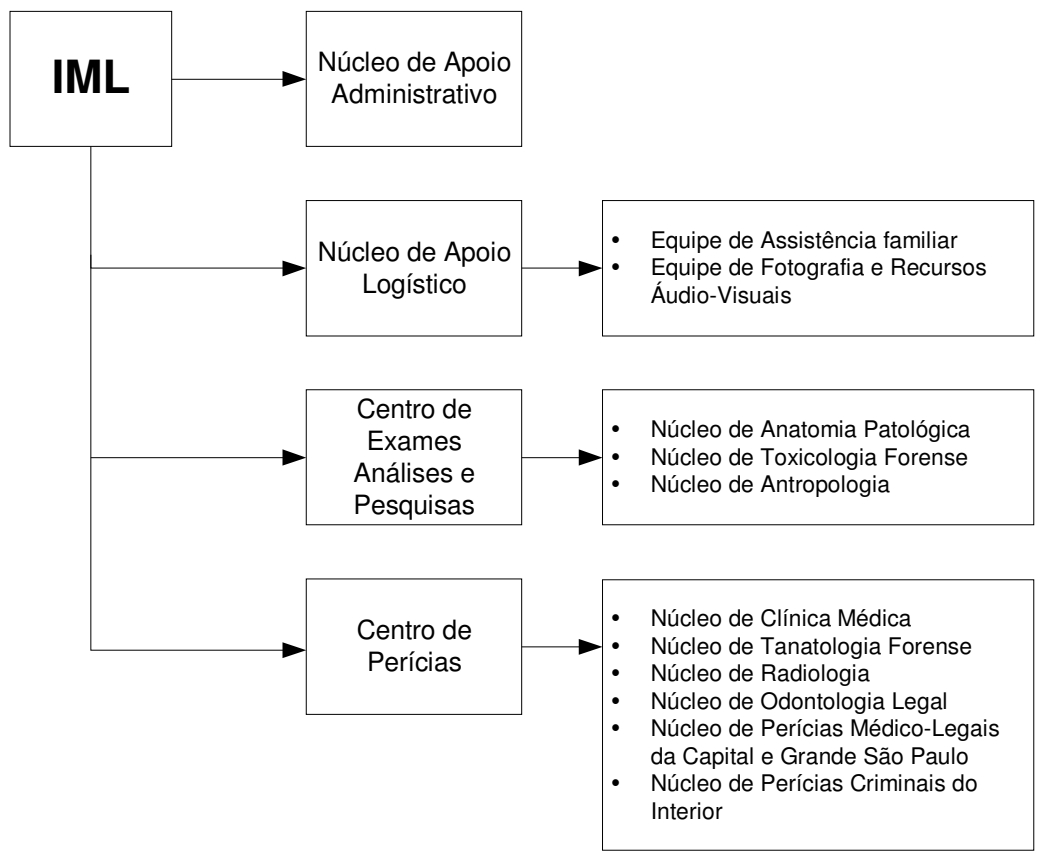

O quadro elenca os exames de corpo de delito privativos dos médicos-legistas:

\begin{tabular}{|c|c|}
\hline Núcleo responsável & Atribuição \\
\hline \multicolumn{2}{|c|}{ Centro de Perícias } \\
\hline Núcleo de Clínica Médica & $\begin{array}{l}\text { Prestar orientação técnica, normatizar, fiscalizar e promover a } \\
\text { realização de perícias nas diversas especialidades médicas. }\end{array}$ \\
\hline Núcleo de Tanatologia Forense & $\begin{array}{l}\text { Prestar orientação técnica, fiscalizar e normatizar a execução } \\
\text { de perícias em cadáveres. }\end{array}$ \\
\hline Núcleo de Radiologia & $\begin{array}{l}\text { Realizar exames radiológicos, emitir os respectivos laudos e } \\
\text { zelar pelo equipamento radiológico. }\end{array}$ \\
\hline Núcleo de Odontologia Legal & $\begin{array}{l}\text { Efetuar perícias odontológicas em vivos, objetivando } \\
\text { estabelecer nexo causal, determinar a natureza das lesões } \\
\text { corporais e, se for o caso, avaliar a idade e proceder a } \\
\text { identificação, e, em mortos, visando avaliar a idade e/ou } \\
\text { proceder a identificação. }\end{array}$ \\
\hline $\begin{array}{l}\text { Núcleo de Perícias Médico-Legais da Capital } \\
\text { e Grande São Paulo }\end{array}$ & \multirow{2}{*}{$\begin{array}{l}\text { Prestar orientação técnica; fiscalizar a realização dos exames } \\
\text { a cargo das Equipes de Perícias Médico-Legais subordinadas, } \\
\text { por meio das Equipes de Perícias Médico-Legais, no âmbito } \\
\text { de suas respectivas áreas de atuação; executar exumações e } \\
\text { exames necroscópicos; realizar exames de embriaguez, de } \\
\text { corpo de delito e sexológicos. }\end{array}$} \\
\hline Núcleo de Perícias Médico-Legais do Interior & \\
\hline \multicolumn{2}{|c|}{ Centro de Exames, Análises e Pesquisas } \\
\hline Núcleo de Anatomia Patológica & $\begin{array}{l}\text { Realizar exames histológicos e citológicos em órgãos, ou } \\
\text { seus fragmentos, e em secreções procedentes de seres } \\
\text { humanos, com o objetivo de subsidiar a perícia médico-legal. }\end{array}$ \\
\hline Núcleo de Toxicologia Forense & $\begin{array}{l}\text { Efetuar exames em sangue, urina, secreções e vísceras de } \\
\text { seres humanos, a fim de detectar substâncias que causem } \\
\text { envenenamento e/ou dependência. }\end{array}$ \\
\hline Núcleo de Antropologia & $\begin{array}{l}\text { Realizar perícias e pesquisas em cadáveres humanos } \\
\text { esqueletizados, ossos, dentes e pêlos, visando à identificação } \\
\text { médico-legal. }\end{array}$ \\
\hline
\end{tabular}




\subsection{O Instituto de Criminalística}

Ao Instituto de Criminalística está afeta a tarefa de realizar todos os exames destinados a instruir processos penais e que não sejam de atribuição do IML ou do IIRGD.

A grande generalidade das perícias pertence aos peritos criminais, abrangendo exames em documentos, crimes contra a pessoa, crimes contra o patrimônio, acidentes de trânsito e outros.

Com a criação da Superintendência da Polícia Técnico-Científica, a estrutura do Instituto de Criminalística passou a apresentar divisões entre as unidades técnicas baseadas em três critérios: a habilitação profissional requerida (específicas de portadores de determinada formação universitária) ${ }^{23}$; o grau de especialização (própria da criminalística, mas sem uma especificidade universitária definida) e a região atendida ${ }^{24}$.

O esquema a seguir resume a estrutura atual do Instituto de Criminalística ${ }^{25}$ :

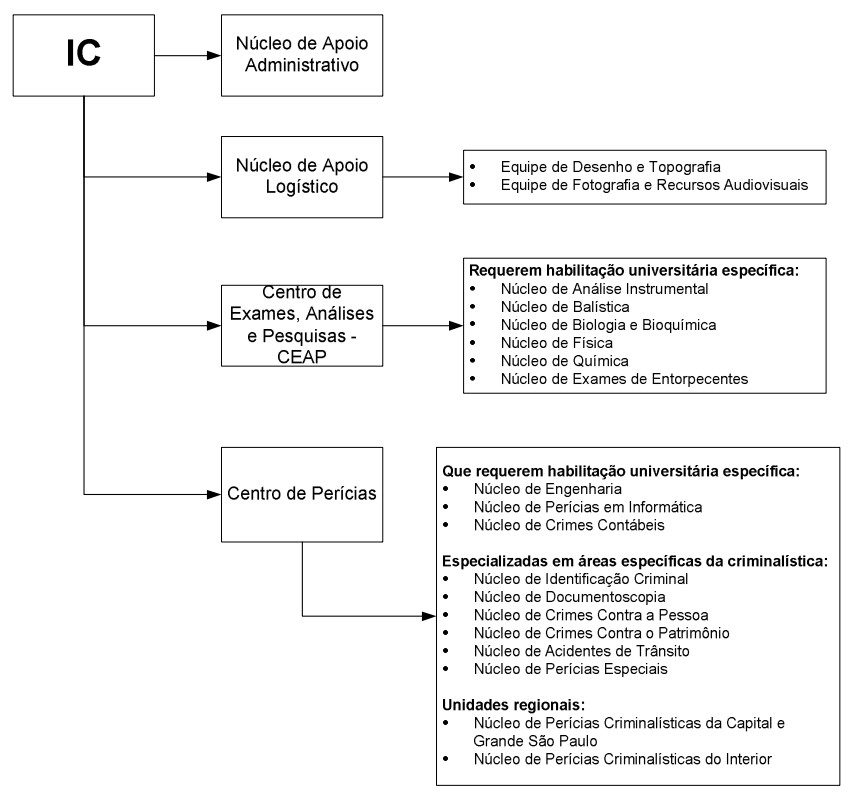

Como seria praticamente impossível esgotar o extenso rol de exames realizados pelo Instituto de Criminalística, o quadro aponta algumas das perícias mais freqüentes, realizadas por cada núcleo:

\footnotetext{
${ }^{23}$ Vide item 1.7.

${ }^{24}$ NEGRINI NETO, Osvaldo. Manual de requisições periciais. Edição eletrônica. São Paulo: APMP, 2002. p. 9 .

${ }^{25}$ Segundo o Decreto Estadual no 48.009/03.
} 


\begin{tabular}{|c|c|}
\hline Núcleo responsável & Atribuição \\
\hline \multicolumn{2}{|r|}{ Centro de perícias } \\
\hline Núcleo de Acidentes de Trânsito & $\begin{array}{l}\text { Perícias de infrações penais de qualquer natureza, que necessitem de } \\
\text { exame em matéria fiscal, contábil ou administrativa. }\end{array}$ \\
\hline $\begin{array}{l}\text { Núcleo de Crimes Contra o } \\
\text { Patrimônio }\end{array}$ & $\begin{array}{l}\text { Exames visando à elaboração de laudos de locais e peças relacionados } \\
\text { com delitos contra o patrimônio, exceto roubo seguido de morte e } \\
\text { furto de água, de energia elétrica, de telefonia ou de } \\
\text { telecomunicações; a propriedade industrial; a organização do } \\
\text { trabalho; o sentimento religioso e o respeito aos mortos; a saúde } \\
\text { pública; a economia popular; jogos ilegais; violação de cofres, caixas- } \\
\text { fortes, sistemas de vigilância, de segurança, de alarme e afins; motim } \\
\text { e fuga de presos e exercício arbitrário das próprias razões. }\end{array}$ \\
\hline Núcleo de Crimes Contra a Pessoa & $\begin{array}{l}\text { Perícias objetivando a elaboração de laudos de locais e peças } \\
\text { relacionados com delitos praticados contra a pessoa, exceto os } \\
\text { homicídios originários de acidente de trânsito ou de acidente do } \\
\text { trabalho; crimes contra os costumes; roubo seguido de morte; } \\
\text { exercício ilegal da medicina, da arte dentária ou da farmacêutica; } \\
\text { encontro de material de origem supostamente humana, de presumível } \\
\text { relação com prática delituosa; exumação e disparo de arma de fogo, } \\
\text { envolvendo tentativa de homicídio. }\end{array}$ \\
\hline Núcleo de Documentoscopia & $\begin{array}{l}\text { Exames relacionados com crimes contra a fé pública em documentos } \\
\text { de qualquer espécie; escrita mecânica e manuscrita e contrafação de } \\
\text { impressos e papéis de segurança, cartões de crédito, cheques e títulos. }\end{array}$ \\
\hline Núcleo de Engenharia & $\begin{array}{l}\text { Perícias visando à elaboração de laudos de locais e peças relacionados } \\
\text { com delitos de perigo comum ou contra a incolumidade pública; } \\
\text { acidentes do trabalho; desabamentos e desmoronamentos; fraude na } \\
\text { construção civil ou no comércio; esbulho possessório, usurpação ou } \\
\text { furto de água, de energia elétrica e de meios de comunicação; } \\
\text { agressão contra o meio ambiente; violação da segurança de meios de } \\
\text { comunicação, transportes e outros serviços públicos; desrespeito ao } \\
\text { consumidor, envolvendo aparelhos mecânicos, incluindo veículos, e } \\
\text { aparelhos elétricos e eletrônicos, exceto os relacionados com } \\
\text { informática. }\end{array}$ \\
\hline Núcleo de Perícias Especiais & $\begin{array}{l}\text { Perícias visando à elaboração de laudos de locais e peças relacionados } \\
\text { com delitos resultantes de ilícitos penais cujo exame não seja de } \\
\text { atribuição específica de outros núcleos do Instituto de Criminalística. } \\
\text { Cooperar e auxiliar, quando solicitado ou determinado por autoridade } \\
\text { competente, nos exames e diligências que se fizerem necessários em } \\
\text { casos mais complexos, incluindo locais de catástrofes ou áreas de } \\
\text { grande extensão territorial, ou quando haja grande diversidade de } \\
\text { material a ser coletado para exame. }\end{array}$ \\
\hline Núcleo de Identificação Criminal & $\begin{array}{l}\text { Identificação de características humanas com emprego de métodos } \\
\text { diversos dos biológicos; identificação de imagens digitais e } \\
\text { impressas, bem como de publicações de conteúdo pornográfico; } \\
\text { averiguação de autenticidade de dados de áudio ou vídeo, em } \\
\text { qualquer meio de gravação. }\end{array}$ \\
\hline Núcleo de Perícias em Informática & $\begin{array}{l}\text { Perícias visando à elaboração de laudos de locais e peças envolvendo } \\
\text { aparelhos computadorizados, software, hardware e periféricos, } \\
\text { relacionados com a prática de infrações penais na área de informática. }\end{array}$ \\
\hline Núcleo de Perícias Criminalísticas & $\begin{array}{l}\text { Sua atribuição varia de acordo com a área correspondente, na capital, } \\
\text { grande São Paulo ou interior. }\end{array}$ \\
\hline
\end{tabular}




\begin{tabular}{|c|c|}
\hline \multicolumn{2}{|c|}{ Centro de Exames, Análises e Pesquisas } \\
\hline Núcleo de Análise Instrumental & $\begin{array}{l}\text { Identificação, adulterações ou falsificações de produtos } \\
\text { farmacêuticos; composição, adulterantes ou grau de pureza de drogas } \\
\text { psicoativas; identificação de venenos. }\end{array}$ \\
\hline Núcleo de Balística & $\begin{array}{l}\text { Efetuar exames e confrontos em armas de fogo e peças de munição, } \\
\text { para o estabelecimento de sua natureza, eficácia para a prática da } \\
\text { infração penal e individualização. }\end{array}$ \\
\hline Núcleo de Biologia e Bioquímica & $\begin{array}{l}\text { Identificação de fluidos biológicos, em suportes ou in natura; } \\
\text { tipagem sangüínea; constatação e identificação de pêlos e cabelos, } \\
\text { exceto os destinados à identificação humana, bem como de fibras } \\
\text { naturais ou artificiais; identificação humana por análise comparativa } \\
\text { de DNA. }\end{array}$ \\
\hline Núcleo de Física & $\begin{array}{l}\text { Proceder aos exames de dispositivos e materiais para caracterização } \\
\text { de forma, disposição, integridade, função, desempenho, atributos, } \\
\text { propriedades ou estrutura; alterações, deformações, fraturas e secções } \\
\text { em materiais diversos, para caracterização do agente; efetuar ensaios } \\
\text { de caracterização de materiais; realizar análises elementares ou de } \\
\text { estruturas cristalinas por microscopia eletrônica de varredura, } \\
\text { difratometria de raios-X ou outros sistemas físicos de precisão e } \\
\text { espectrográficas acústicas. }\end{array}$ \\
\hline Núcleo de Química & $\begin{array}{l}\text { Realizar exames e análises de produtos químicos de origem } \\
\text { industrial; produtos residuais de disparo de arma de fogo; preparar } \\
\text { reagentes específicos para os exames de interesse criminalístico; } \\
\text { efetuar análises químicas por via clássica, cromatografia ou } \\
\text { espectrofotometria de substâncias orgânicas e inorgânicas. }\end{array}$ \\
\hline Núcleo de Exames de Entorpecentes & $\begin{array}{l}\text { Exames de identificação, constatação e comprovação de substâncias } \\
\text { tóxicas e de outras drogas classificadas como causadoras de } \\
\text { dependência física ou psíquica. }\end{array}$ \\
\hline
\end{tabular}

\subsection{O Instituto de Identificação Ricardo Gumbleton Daunt}

Ao Instituto de Identificação Ricardo Gumbleton Daunt ${ }^{26}$ (IIRGD) cabe a pesquisa e a realização de perícias relativas à classificação, centralização e arquivamento de individuais datiloscópicas para efeito de pesquisa e comparação; a pesquisa datiloscópica em documentos, tanto na esfera cível quanto na criminal; a coleta e a análise de fragmentos e impressões papilares encontradas em locais de crime, visando à identificação de pessoas suspeitas do cometimento de infrações penais; a identificação datiloscópica de cadáveres, despojos humanos e desconhecidos e a expedição de Carteiras de Identidade.

Embora realize perícias e elabore laudos, os técnicos do IIRGD não recebem a designação de peritos, mas sim de pesquisadores papiloscópicos e papiloscopistas

\footnotetext{
${ }^{26}$ Chefe e posteriormente diretor do Serviço de Identificação de São Paulo, que hoje leva o seu nome (IIRGD - Instituto de Identificação Ricardo Gumbleton Daunt). É considerado o precursor da polícia científica e um dos introdutores do serviço de identificação no Brasil.
} 
policiais $^{27}$. Os primeiros, pesquisadores, têm por função a pesquisa e o levantamento dos fragmentos e impressões encontrados em locais de crime, das pessoas, nos postos de identificação, e de cadáveres não identificados. Os papiloscopistas efetuam a classificação, o estudo e o cotejo dessas impressões, procurando a identificação.

\subsection{Outras instituições}

O IC, o IML e o IIRGD, cujas atribuições restringem-se praticamente à produção de perícias da área penal, não realizam exames relacionados a infrações administrativas, tais como poluição de meio ambiente, uso indevido de medicamentos, aferição de medidas, quantidades em embalagens, suspeita de adulteração de combustíveis e outros.

Nessas hipóteses, devem ser acionados outros órgãos públicos, até porque, em determinados casos, existem normas específicas para a coleta de materiais que os institutos mencionados não têm condições de cumprir.

Entre os órgãos públicos encarregados desses exames, no Estado de São Paulo, podemos $\operatorname{citar}^{28}$ :

- Instituto de Pesquisas Tecnológicas do Estado de São Paulo (IPT);

- Instituto de Pesquisas Energéticas e Nucleares (IPEN);

- Instituto Biológico (IB);

- Instituto Adolfo Lutz (IAL);

- Instituto de Pesos e Medidas do Estado de São Paulo (IPEM);

- Instituto de Medicina Social e de Criminologia de São Paulo (IMESC);

- Companhia de Tecnologia de Saneamento Ambiental (CETESB);

- Agência Nacional do Petróleo (ANP);

- Grupo de Operações Táticas Especiais da Polícia Militar (GATE); e

\footnotetext{
${ }^{27}$ No Estado de São Paulo, ao menos até o momento, não se exige formação universitária dos papiloscopistas e pesquisadores papiloscópicos. Entretanto, há em tramitação na Assembléia Legislativa, o Projeto de Lei Complementar Estadual no 46/2003, que prevê a exigência de diploma de nível superior ou habilitação legal para os papiloscopistas.

${ }^{28}$ NEGRINI NETO, Osvaldo. op. cit., p. 70-74.
} 
- Departamento de Perícias Médicas do Estado (DPME).

\subsubsection{Instituto de Pesquisas Tecnológicas do Estado de SP (IPT)}

O IPT atua na realização de mais de 2300 ensaios e pesquisas nas áreas de economia e engenharia de sistemas, engenharia civil, informática e telecomunicações, geologia e mineralogia, mecânica e eletricidade, metalurgia, química e metrologia química, produtos florestais (papel e celulose), tecnologia de couros e calçados, tecnologia de transportes (naval, ferroviário e rodoviário), análise de embalagens, indústria têxtil e outros.

Produz pareceres técnicos, relatórios (de ensaio, medição e referência técnica), certificações (de calibração, de conformidade e de materiais de referência) e relatórios de atendimento tecnológico, sempre em atendimento a solicitações de pessoas físicas ou jurídicas e mediante remuneração do interessado.

Excepcionalmente, em perícias relacionadas a crimes contra o consumidor (Lei $\mathrm{n}^{\circ}$ 8.078, de 11 de setembro de 1990), os serviços do IPT podem ser solicitados pelo Instituto de Criminalística, mas a perícia deverá ser paga pelo interessado.

\subsubsection{Instituto de Pesquisas Energéticas e Nucleares (IPEN)}

Realiza análises e pesquisas relacionadas com biologia molecular, células combustíveis, tecnologia de materiais, desenvolvimento e fabricação de combustíveis nucleares, engenharia nuclear, laser e suas aplicações, radiofarmácia, rejeitos radioativos, e tecnologia das radiações.

O Instituto de Criminalística possui um convênio com o IPEN para a realização de exames que reclamem equipamentos e pessoal de alta especialização. 


\subsubsection{Instituto Biológico (IB)}

O Instituto Biológico tem por atribuições o desenvolvimento e a transferência de conhecimento científico e tecnológico para o negócio agrícola nas áreas de proteção ambiental e sanidade animal e vegetal, objetivando melhoria na qualidade de vida da população e de suas relações com o meio ambiente.

Pode, em casos especiais, auxiliar o Instituto de Criminalística na elaboração de perícias relacionadas com a sua área de atuação.

\subsubsection{Instituto Adolfo Lutz (IAL)}

O Instituto Adolfo Lutz tem como atribuições controlar a qualidade da produção dos laboratórios da rede Estadual, orientando a organização dos serviços técnicoespecializados, promovendo a introdução de tecnologia, reciclando pessoal e avaliando resultados; atuar como referência técnica de laboratórios integrantes do Sistema de Saúde no Estado de São Paulo; realizar atividades laboratoriais pertinentes ao seu nível de complexidade; realizar investigações e pesquisas pertinentes à sua finalidade e papel no Sistema de Saúde e divulgar os resultados; informar o Conselho das Vigilâncias da Secretaria de Estado da Saúde de São Paulo sobre os resultados de investigações e observações realizadas pelo Instituto, consideradas relevantes para o controle ou eliminação de agravos e riscos à saúde da população, e participar da elaboração das diretrizes e definições das políticas em Saúde e em Ciência e Tecnologia ${ }^{29}$.

Realiza exames de laboratórios para diagnóstico de moléstias transmissíveis, imunológicas e neoplásicas; exames histopatológicos, citológicos e necrópsias de interesse sanitário e de medicina preventiva; análise de produtos químicos e biológicos de drogas, medicamentos oficiais e especialidades farmacêuticas de produtos de higiene e toucador, desinfetantes e similares; exames físicos, químicos, biológicos e microscópicos de alimentos naturais e industrializados, dietéticos, água e bebidas em geral; exames de plásticos, vernizes e outros materiais de embalagem; análises clínicas auxiliares de

\footnotetext{
${ }^{29}$ INSTITUTO ADOLFO LUTZ. Disponível em: <www.ial.sp.gov.br>.
} 
interesse da saúde pública; estudo e pesquisa da etiologia de endemias, epidemias e antropozoonoses $^{30}$.

Recentemente foi editado um Termo de Cooperação Técnica entre a Secretaria da Saúde e o Instituto Adolfo Lutz, objetivando o atendimento de todas as perícias relacionadas com infrações sanitárias (descritas na Lei nº 6.437 de 20 de agosto de 1977).

Além disso, em outros casos, quando o Instituto de Criminalística não dispuser da metodologia necessária para a realização de algum exame específico, poderá solicitar auxílio ao IAL.

Importante lembrar que a perícia relacionada com laticínios, carnes e embutidos é de atribuição do Ministério da Agricultura, Pecuária e Abastecimento, por intermédio do Serviço de Inspeção Federal - SIF.

\subsubsection{Instituto de Pesos e Medidas do Estado de São Paulo (IPEM)}

O Instituto de Pesos e Medidas do Estado de São Paulo (IPEM) é um órgão de proteção às relações de consumo, na área relacionada à metrologia legal ${ }^{31}$, exercendo a verificação e a fiscalização de instrumentos de medição (balanças, bombas de combustível, peso de embalagens, etc.), produtos pré-medidos ${ }^{32}$, artigos têxteis (em relação à qualidade das fibras componentes), produtos com certificação compulsória ${ }^{33}$ e veículos transportadores de produtos perigosos ${ }^{34}$.

\footnotetext{
${ }^{30}$ Atribuições conferidas pelo Decreto-lei $\mathrm{n}^{\mathrm{o}} 11.522$ de 26 de outubro de 1940 , modificado pelo art. $2^{\circ}$ do Decreto $\mathrm{s} / \mathrm{n}^{\circ}$ de 28/04/70 (Apud NEGRINI, 2002, p. 72).

${ }^{31}$ Parte da metrologia que se refere às exigências legais, técnicas e administrativas, relativas às unidades de medida, aos métodos de medição, aos instrumentos de medir e às medidas materializadas.

${ }^{32}$ Produto pré-medido é aquele cuja quantidade é determinada sem que o consumidor tenha acesso ao processo de medição. Geralmente é acondicionado em embalagem que traz no rótulo a quantidade de produto nela contida.

${ }^{33}$ Existem produtos que, por suas características, podem colocar em risco a saúde e a segurança do usuário ou do meio ambiente se fabricados de maneira inadequada. Por isso, são certificados compulsoriamente, ou seja, devem obedecer rigorosamente as normas específicas de produção estabelecidas pelo INMETRO. São exemplos os brinquedos, capacetes para motociclistas, fios e cabos elétricos, extintores de incêndio, botijões, mangueiras e reguladores de gás, preservativos e outros.

${ }^{34}$ Veículos transportadores de determinados produtos químicos (xileno, tolueno, etc.) e de combustíveis líquidos (gasolina, álcool etílico carburante, óleo diesel, querosene e gasolina de aviação).
} 


\subsubsection{Instituto de Medicina Social e Criminologia de SP (IMESC)}

Tem por atribuição a realização de perícias médico-legais, psiquiátricas e imunohematológicas requisitadas pelo Poder Judiciário Estadual ou Federal, tanto na esfera cível quanto na criminal. Os exames são gratuitos desde que decorrentes de requisição judicial.

$\mathrm{Na}$ área penal atua nos casos de verificação de insanidade mental (art. 149 do CPP), dependência toxicológica (art. 23, $\S 1^{\circ}$, da Lei $n^{\circ} 6.368 / 76$ ) e cessação de periculosidade (art. 715 do CPP).

$\mathrm{Na}$ área cível, ensaios imuno-hematológicos (incluindo DNA) em ações de investigação de paternidade ou maternidade, negatória de filiação ou paternidade e correlatas. Realiza também perícias médico-legais, em ações acidentárias, previdenciárias e reparações de dano, anulações de casamento, verificação de idade e outras. No campo da psiquiatria forense, exames nos casos de interdição, tutela, curatela, modificação de guarda de menores, anulação de casamento (por fatores psíquicos), avaliações psiquiátricas em geral, para ações indenizatórias, anulatórias de atos jurídicos.

\subsubsection{Companhia de Tecnologia de Saneamento Ambiental (CETESB)}

A CETESB tem por objetivos fiscalizar os padrões de qualidade ambiental no Estado, organizar e disponibilizar dados e informações sobre a qualidade ambiental e fontes de poluição, desenvolver indicadores e monitorar o desempenho nas diversas áreas de interesse ambiental.

Para alcançar esses objetivos, promove o licenciamento ambiental ${ }^{35}$ e a fiscalização de fontes fixas ${ }^{36}$, a fiscalização das fontes móveis, o monitoramento da qualidade do ar e das águas, assim como o estudo da balneabilidade ${ }^{37}$ das praias.

\footnotetext{
${ }^{35}$ Licenciamento ambiental é o procedimento pelo qual o órgão ambiental competente permite a localização, instalação, ampliação e operação de empreendimentos e atividades que utilizam recursos ambientais e possam ser efetiva ou potencialmente poluidoras ou possam causar degradação ambiental.

${ }^{36}$ Fontes poluidoras.

${ }^{37}$ Balneabilidade é a qualidade das águas destinadas à recreação de contato primário, ou seja, aquele direto e prolongado com a água (natação, mergulho, esqui-aquático, etc.), em que a possibilidade de ingestão de quantidades apreciáveis de água é elevada.
} 
Possui tecnologia e metodologia para coleta de materiais e exames comprobatórios de crimes e infrações ambientais, como poluição do ar, água, solo, etc.

\subsubsection{Agência Nacional do Petróleo (ANP)}

A Agência Nacional do Petróleo é uma autarquia federal, vinculada ao Ministério de Minas e Energia, que tem por finalidade a regulação, a contratação e a fiscalização das atividades relacionadas com a indústria do petróleo (Lei $\mathrm{n}^{\circ}$ 9.478, de 06 de agosto de 1997). É responsável pelos exames de combustíveis, verificação de sua composição, normas, etc.

\subsubsection{Grupo de Operações Táticas Especiais da Polícia Militar (GATE)}

É o órgão responsável pela análise de explosivos e artefatos intactos de alta periculosidade, como bombas químicas, biológicas, equipamentos usados em sabotagens e outros.

O Instituto de Criminalística só realiza perícias nesses casos após a ocorrência do fato concreto, ou seja, já tendo ocorrido a explosão.

\subsubsection{Departamento de Perícias Médicas do Estado (DPME)}

Tem por atribuições realizar, para fins administrativos, perícias médicoodontológicas de avaliação da sanidade e da capacidade física de candidatos a cargos ou funções públicas do serviço civil estadual; exames de comprovação de invalidez permanente para fins de aposentadoria e exames para fins de concessão de licença para tratamento de saúde ou maternidade. 


\subsection{Estrutura Federal}

A perícia federal atua na área penal em crimes relacionados com o tráfico internacional de entorpecente, falsificação de moeda, contrabando e descaminho, e outros relacionados com a área de competência da Justiça Federal.

Para atender a essas perícias existe a Diretoria Técnico-Científica, que engloba o Instituto Nacional de Identificação - $\mathrm{INI}^{38}$ e o Instituto Nacional de Criminalística - INC, ambos com sede em Brasília, estruturados como órgãos da Polícia Federal.

O Instituto Nacional de Criminalística - INC conta com um quadro de 850 peritos criminais, já computadas 500 (quinhentas) novas vagas criadas em 2005 e ainda não totalmente preenchidas. São técnicos de nível superior, especializados nas áreas de biologia, ciências contábeis, economia, engenharia, farmácia, geologia, informática, medicina, química e veterinária.

Apesar de ter em seus quadros peritos médicos, não existe na Polícia Federal uma equipe de médicos-legistas e respectivos IMLs. Em razão da pequena demanda, quando necessário, os Institutos Médico-Legais dos Estados realizam os exames.

Nos Estados, o Instituto Nacional de Criminalística mantém Seções TécnicoCientíficas - SETECs, dotadas de peritos criminais encarregados de atender à demanda da região.

A seguir, reproduzimos o organograma da Diretoria Técnico-Científica da polícia Federal:

\footnotetext{
${ }^{38} \mathrm{O}$ Instituto Nacional de Identificação (INI) é órgão técnico do Departamento de Polícia Federal, inaugurado em 21 de setembro 1963, em Brasília-DF, e tem por finalidade planejar, dirigir, coordenar, executar e controlar as atividades relacionadas com a identificação criminal e de estrangeiros no país.
} 


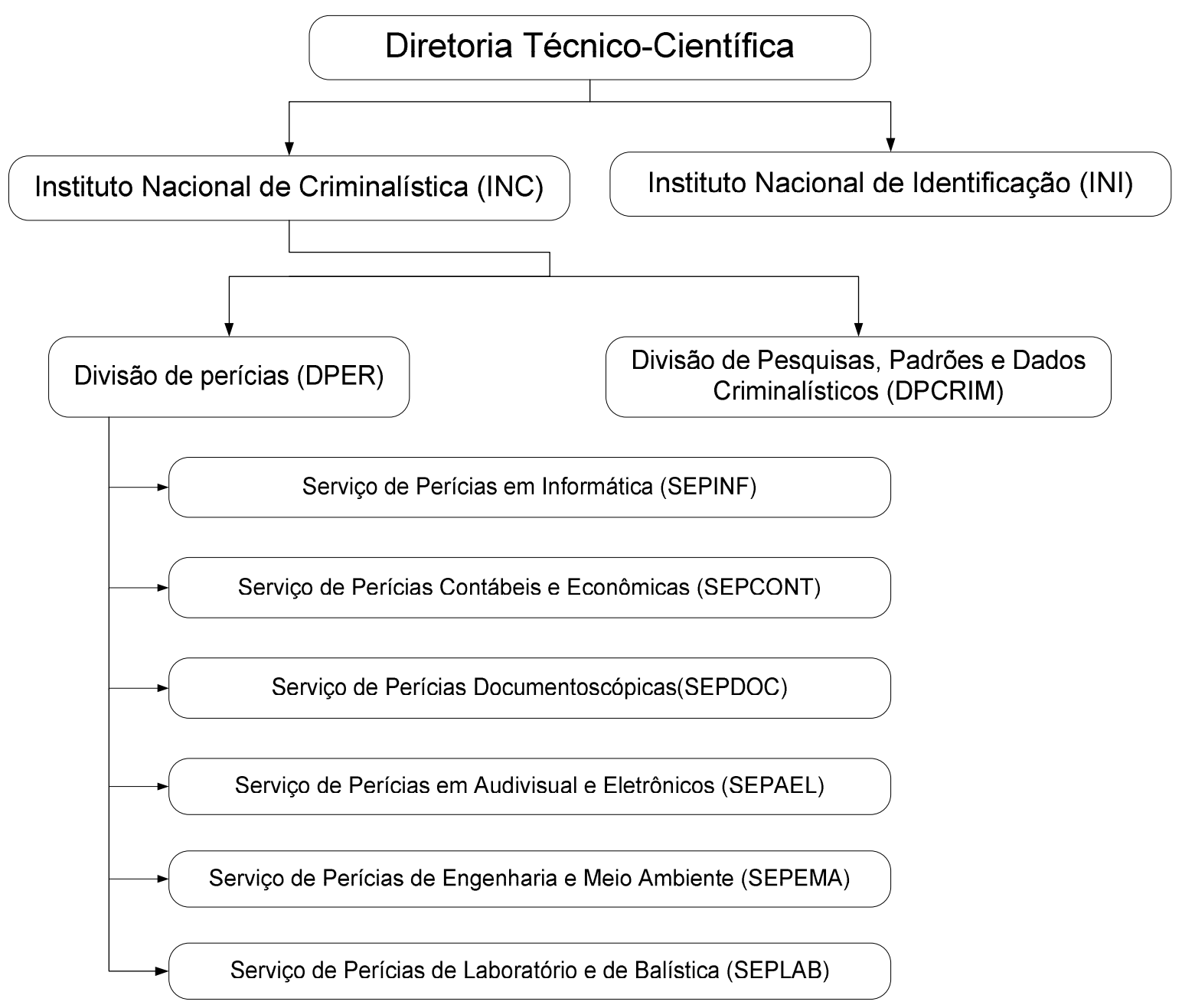

\subsection{Peritos - A Lei no $11.690 / 08$}

A Lei n ${ }^{\circ} 11.690$, de 9 de junho de 2008, modificou diversos dispositivos do Código de Processo Penal (Decreto-Lei no 3.689, de 3 de outubro de 1941), relativos à disciplina da prova. Uma destas alterações recaiu sobre o art. 159 do CPP, modificando de forma bastante significativa o panorama de produção dos exames periciais, no que toca à figura dos peritos.

\subsubsection{Peritos}

Denominados experts pelos ingleses e sachverständige pelos alemães, a denominação perito, do latim peritus (aquele que sabe por experiência, que tem prática), deriva dos conhecimentos que a pessoa indicada para o encargo deve ter em relação ao 
objeto de seu exame ${ }^{39}$ e que faltam ao juiz. Esse requisito, porém, não é absoluto. Quando o magistrado, apesar de leigo, for capaz de proceder pessoalmente às observações necessárias, mas tiver receio de fazê-lo por questões de conveniência ou segurança, poderá encarregar do exame terceira pessoa, que, embora não atue em razão dos conhecimentos técnicos específicos, será considerada perito.

Peritos são, dessa maneira, todos os técnicos, de nível superior ou não, concursados ou não, mas especializados em determinada área do conhecimento humano e que, por designação da autoridade competente (delegado de polícia ou autoridade judiciária), prestam serviços à Justiça ou à Polícia a respeito de fatos, pessoas ou coisas.

"São pessoas físicas que, em razão de conhecimentos científicos, técnicos, artísticos, etc., assessoram a justiça com a cultura especializada de que são detentoras"40 ou, nas palavras de Wilhelm Kisch, “órgãos auxiliares da administração da Justiça que assistem ao juiz quando a prova do fato depender de conhecimento técnico ou científico, ao contrário do que acontece com a testemunha, que é tão-só terceiro" ${ }^{41}$.

\subsubsection{Classificação e investidura}

Investidura é o ato pelo qual a autoridade pública dá posse e o perito assume o cargo ou encargo de realizar a perícia. De acordo com a investidura, os peritos classificamse em oficiais, leigos ou ad hoc, louvados ou nomeados e assistentes técnicos.

\subsubsection{Peritos oficiais e peritos leigos ou ad hoc}

No Processo Penal, excetuando-se a figura dos assistentes técnicos (art. 159, $\S \S 3^{\circ} \mathrm{e}$ $5^{\circ}$, II, do CPP), introduzida pela lei 11.690, de 09/06/08, os peritos, médicos ou não, devem atuar por dever de ofício.

\footnotetext{
${ }^{39}$ Fatos, pessoas ou coisas.

${ }^{40}$ ZARZUELA, José Lopes; MATUNAGA, Minoru; THOMAZ, Pedro Lourenço. op. cit. p. 329.

${ }^{41}$ Elementos de Derecho Procesal Civil, 1940, p. 226. Apud, MARQUES, José Frederico. Op. cit., v. 3, p. 418.
} 
São funcionários públicos concursados para exercer o mister de realizar perícias nas diversas áreas e atuam por requisição da autoridade ao diretor da repartição a que pertencem (arts. $6^{\circ}$, VII, 178 e 276 do CPP).

\section{CPP}

Art. $6^{\circ}$. Logo que tiver conhecimento da prática da infração penal, a autoridade policial deverá:

VII - determinar, se for caso, que se proceda a exame de corpo de delito e a quaisquer outras perícias;

Art. 159. O exame de corpo de delito e outras perícias serão realizados por perito oficial, portador de diploma de curso superior (Redação dada ao $\S 1^{\circ}$ pela Lei $n^{\circ} 11.690$, de $09 / 06 / 08$ ).

Art. 178. No caso do art. 159, o exame será requisitado pela autoridade ao diretor da repartição, juntando-se ao processo o laudo assinado pelos peritos.

Art. 276. As partes não intervirão na nomeação do perito.

Por autoridade competente, no caso, deve-se entender o delegado de polícia, na fase de inquérito, ou juiz de direito, uma vez instaurado o processo. O promotor de justiça, ao receber o inquérito policial ou chegando-lhe às mãos material que necessite da intervenção técnica, também pode requisitar aos Institutos Médico-Legal e de Criminalística a realização da perícia pertinente, com fundamento no art. 129, VI e VIII da Constituição Federal e no art. 26, I, b, da Lei nº 8.625, de 12 de fevereiro de 1993.

Quando a perícia for de natureza médico-legal o exame deverá, preferencialmente, ser realizado por profissional médico, também denominado perito médico ou médicolegista. Quando de outra natureza, a responsabilidade deverá recair sobre profissional de curso superior denominado perito criminal.

Os requisitos para que alguém possa ser médico-legista são:

- ter maioridade civil;

- possuir diploma registrado de medicina, oriundo de faculdade oficial ou reconhecida pelo MEC;

- $\quad$ aprovação em concurso público. 
Os requisitos para que alguém possa ser perito criminal são:

- $\quad$ ter maioridade civil;

- possuir diploma registrado de curso superior pleno, oficial ou reconhecido pelo MEC, de uma das áreas indicadas no edital do concurso;

- aprovação em concurso público.

Muito embora a obrigatoriedade de formação superior seja um requisito que já vinha sendo aplicado na maioria dos Estados, a Lei $n^{\circ} 11.690$, de 09 de junho de 2008 passou a exigi-lo expressamente, resguardando o direito de peritos criminais que ingressaram sob o regime anterior por meio de uma regra de transição permissiva inserta em seu art. $2^{\text {o: }}$

\section{Lei $n^{\circ} 11.690 / 08$}

Art. $2^{\circ}$ Aqueles peritos que ingressaram sem exigência do diploma de curso superior até a data de entrada em vigor desta Lei continuarão a atuar exclusivamente nas respectivas áreas para as quais se habilitaram, ressalvados os peritos médicos.

Na ausência de perito oficial, ou se a instituição pública não dispuser de serviço próprio para o exame que se pretende realizar, o juiz poderá nomear duas pessoas idôneas, de nível superior para a realização da perícia. É o que dispõe o $§ 1^{\circ}$ do art. 159 do Código de Processo Penal.

Tais peritos, também chamados de peritos leigos ou ad hoc, deverão ser sempre profissionais de curso superior, preferencialmente na área técnica específica, relacionada com a natureza do exame.

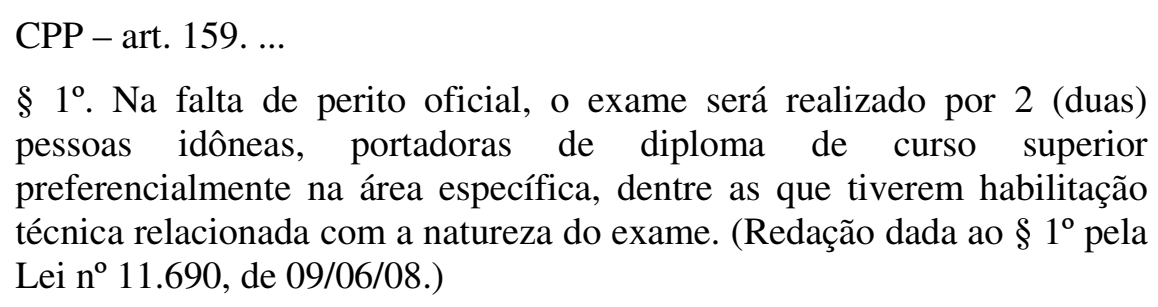
pessoas idôneas, portadoras de diploma de curso superior preferencialmente na área específica, dentre as que tiverem habilitação técnica relacionada com a natureza do exame. (Redação dada ao $\S 1^{\circ}$ pela Lei no 11.690, de 09/06/08.)

Os requisitos para que alguém possa ser perito leigo ou ad hoc no processo penal são:

- ausência de peritos oficiais capacitados; 
- maioridade civil;

- ser portador de diploma registrado de curso superior;

- ser matriculado no órgão de classe da categoria (quando o caso);

- ter habilitação técnica relacionada à natureza do exame;

- possuir reconhecida idoneidade moral; e

- gozar de absoluta confiança do juízo.

\subsubsection{Peritos nomeados ou louvados}

Na esfera cível e trabalhista, até pela diversidade de questões apreciadas, os exames não são normalmente efetuados por peritos oficiais, mas por especialistas nomeados pelo juiz. São os peritos nomeados ou louvados, nos termos do art. 421 do Código de Processo Civil e art. $3^{\circ}$ da Lei $n^{\circ} 5.584$, de 26 de junho de 1970.

\subsubsection{Assistentes técnicos}

Finalmente, temos a figura dos assistentes técnicos, que nada mais são que profissionais da confiança das partes, indicados para acompanhar o exame do perito oficial ou nomeado pelo juiz.

Até o advento da Lei ${ }^{\circ} 11.690$, de 09 de junho de 2008, a indicação de assistentes técnicos pelas partes ficava restrita ao processo civil (art. 421, $\S 1^{\circ}$, I, do CPC) e trabalhista (art. $3^{\circ}$, parágrafo único, da Lei n ${ }^{\circ} 5.584 / 70$ ). Agora, também no processo penal (art. 159, $\S \S 3^{\circ}$ e $5^{\circ}$, II, do CPP), o Ministério Público, o assistente de acusação, o ofendido, o querelante e o acusado têm a faculdade de indicar assistentes técnicos, com algumas peculiaridades em relação ao processo civil.

CPC - Art. 421....

$\S 1^{\circ}$. Incumbe às partes, dentro em 5 (cinco) dias, contados da intimação do despacho de nomeação do perito:

I - indicar o assistente técnico; 
Lei $n^{\circ} 5.584 / 70$

Art. $3^{\circ} \ldots$

Parágrafo único. Permitir-se-á a cada parte a indicação de um assistente, cujo laudo terá que ser apresentado no mesmo prazo assinado para o perito, sob pena de ser desentranhado dos autos.

CPP - Art. 159. ...

$\S 3^{\circ}$ Serão facultadas ao Ministério Público, ao assistente de acusação, ao ofendido, ao querelante e ao acusado a formulação de quesitos e indicação de assistente técnico $\left(\S 3^{\circ}\right.$ acrescido pela Lei $\mathrm{n}^{\circ} 11.690$, de 09/06/08).

$\S 5^{\circ}$ Durante o curso do processo judicial, é permitido às partes, quanto à perícia:

II - indicar assistentes técnicos que poderão apresentar pareceres em prazo a ser fixado pelo juiz ou ser inquiridos em audiência $\left(\S 5^{\circ}\right.$ acrescido pela Lei no 11.690 , de 09/06/08).

Os assistentes técnicos, para serem admitidos como tais, devem preencher os seguintes requisitos:

- maioridade civil;

- ter, preferencialmente, formação universitária plena;

- ter capacidade científica, técnica ou artística para o desempenho da função;

- possuir reconhecida idoneidade moral; e

- gozar da confiança das partes.

Não se aplicam aos assistentes técnicos as regras relativas à suspeição, restritas unicamente aos peritos (art. 422 do CPC, que por analogia também deve ser aplicado ao processo penal, omisso).

Deve-se observar que também é admissível a indicação de pessoa jurídica para servir como assistente técnico (STJ - Recurso Especial no 1993/0018648-5, Ministro Sálvio de Figueiredo Teixeira - DJ 27/09/1993, p. 19823, REVFOR 325/155). 


\subsubsection{Momento de admissão dos assistentes técnicos}

Quanto ao momento de admissão dos assistentes técnicos, as regras do processo civil e do trabalho diferem das do processo penal.

Enquanto nos primeiros a perícia, excetuando-se eventual produção antecipada de prova, tem lugar somente depois de estabelecida a relação processual, no processo penal os exames podem ocorrer tanto na fase inquisitiva (regra), como também durante o contraditório (exceção).

Além disso, no processo civil (art. 421, $\S 1^{\circ}$, I do CPC) e trabalhista (art. $3^{\circ}$, parágrafo único, da Lei $\mathrm{n}^{\circ}$ 5.584/70), os assistentes técnicos são nomeados quase que simultaneamente com o perito e podem acompanhar todos os exames ab initio (art. 431-A, do CPC). No processo penal devem ser considerados momentos distintos.

Ao introduzir a figura do assistente técnico indicado pelas partes, garantindo sua atuação a partir da admissão pelo juiz, a Lei $n^{0} 11.690$, de 09 de junho de 2008, não estabeleceu claramente o momento do exame ou a forma como deve intervir.

Uma leitura pura e simples do novo $\S 3^{\circ}$ do art. 159 do CPP poderia levar à interpretação de que a figura do assistente técnico somente teria lugar na fase processual, vedada sua admissão durante o inquérito policial. É que o aludido dispositivo menciona a possibilidade de indicação de assistente técnico pelo Ministério Público, assistente de acusação, ofendido, querelante e acusado (figuras existentes apenas na fase processual), silenciando em relação ao averiguado ou indiciado.

Entendemos que a redação é meramente exemplificativa e tem por objetivo ampliar a abrangência do dispositivo, para atingir todos os atores da relação jurídica, quer durante o processo como na fase de inquérito.

Note-se que o $\S 5^{\circ}$, II, do mesmo art. 159, prevê a possibilidade de indicação de assistentes técnicos pelas partes durante o curso do processo, disposição que seria inútil, salvo se admitirmos que o rol dos habilitados a apresentar assistente técnico, previsto no $\S$ $3^{\circ}$, inclua também o indiciado e o averiguado.

Em segundo lugar, no processo penal, as perícias clamam por celeridade, não sendo razoável impedir o averiguado ou o indiciado, por intermédio de seus assistentes técnicos, de analisar as provas produzidas, mesmo durante a fase policial, até porque há inquéritos 
que se arrastam por anos sem que ocorra o oferecimento de denúncia pelo Ministério Público.

Por último, o art. 176 do Código de Processo Penal faz alusão à possibilidade de formulação de quesitos pela autoridade e pelas partes até o ato da diligência, sem distinção do momento processual, raciocínio que pode ser estendido à atuação dos assistentes técnicos, até porque deles é a tarefa ínsita de questionar a perícia.

\section{CPP}

Art. 176. A autoridade e as partes poderão formular quesitos até o ato da diligência.

Assim, acreditamos ser possível a indicação de assistentes técnicos pelas partes, tanto na fase de inquérito, como uma vez estabelecida a relação processual. De qualquer modo, a função dos assistentes técnicos é de acompanhar a perícia, não podendo interferir na sua realização, à semelhança do que ocorre no processo civil.

Quando a indicação se der na fase inquisitiva, a atuação ocorrerá mediante admissão pelo juiz e preferencialmente após a conclusão dos trabalhos e elaboração do laudo pelos peritos oficiais (art. 159, $\S 4^{\circ}$ do CPP).

CPP - Art. 159....

$\S 4^{\circ} \mathrm{O}$ assistente técnico atuará a partir de sua admissão pelo juiz e após a conclusão dos exames e elaboração do laudo pelos peritos oficiais, sendo as partes intimadas dessa decisão ( $\S 4^{\circ}$ acrescido pela Lei $\mathrm{n}^{\circ} 11.690$, de 09/06/08).

Essa disposição decorre da própria natureza do exame pericial na área penal, realizado, quase sempre, logo após os fatos e antes que se estabeleça o processo contraditório, o que torna o assistente técnico, na maioria das vezes, simples parecerista, mero crítico do trabalho técnico elaborado pelo órgão oficial.

A determinação legal no sentido de que a intervenção do assistente técnico deve ser posterior ao exame oficial e após a apresentação do laudo pericial (art. 159, § $4^{\circ}$ do CPP) não nos parece peremptória, mas, como salientamos, preferencial, e tem por objetivo apenas deixar patente que a faculdade de indicação de assistentes técnicos não pode obstar a produção da prova oficial. 
Muito embora a grande maioria dos exames seja realizada logo após os fatos, há diligências complementares e outras perícias, como a reprodução simulada dos fatos, que podem ser efetivadas até mesmo na fase processual, sob o crivo do contraditório.

A regra geral visa apenas resguardar a necessária celeridade da perícia criminal, produzida $a b$ initio, e evitar que, em alguns casos específicos, o cronograma oficial seja afetado pela necessidade, por vezes protelatória, de convocar as partes para cada ato praticado ou de permitir a intervenção de terceiros em ambientes não preparados para receber estranhos e para os quais a contaminação é um fator de risco para a realização da perícia (Justificativa da Emenda de Plenário no 9 ao PLC 37, de 2007 - Lei no 11.690/08 Senadora Serys Slhessarenko).

Sendo assim, não há razão para impedir o assistente técnico, uma vez admitido pelo juízo, de acompanhar a realização de exame determinado na fase inquisitiva ou processual, desde que sua intervenção não cause prejuízo à realização da perícia oficial, sob pena de ficar configurado cerceamento de defesa.

\subsubsection{Modo de atuação dos assistentes técnicos}

Como norma, os assistentes técnicos trabalham sobre perícias já realizadas e emitem seus pareceres tendo como base os laudos elaborados pelo técnico oficial. Não obstante, quando possível, e havendo requerimento das partes, o material probatório que serviu de base à perícia deve ser disponibilizado para exame pelos assistentes, no ambiente do órgão oficial e na presença do perito oficial (art. 159, $\S 6^{\circ}$ do CPP).

CPP - Art. 159. ...

$\S 6^{\circ}$ Havendo requerimento das partes, o material probatório que serviu de base à perícia será disponibilizado no ambiente do órgão oficial, que manterá sempre sua guarda, e na presença do perito oficial, para exame pelos assistentes, salvo se for impossível a sua conservação $\left(\S 6^{\circ}\right.$ acrescido pela Lei $\mathrm{n}^{\mathbf{0}} 11.690$, de 09/06/08).

A legislação menciona, como fator impeditivo da disponibilização do material probatório que serviu de base à perícia, tão-somente a sua impossibilidade de conservação, sendo omissa em relação a outras hipóteses em que o exame pelos assistentes técnicos torna-se inviável. 
Para os exames laboratoriais, entendemos que, além da possibilidade de conservação, a disposição só será aplicável se existir material suficiente para a contraprova (art. 170 do CPP). As perícias realizadas sobre suporte exíguo jamais poderão ser refeitas.

\section{CPP}

Art. 170. Nas perícias de laboratório, os peritos guardarão material suficiente para a eventualidade de nova perícia. Sempre que conveniente, os laudos serão ilustrados com provas fotográficas, ou microfotográficas, desenhos ou esquemas.

Em relação ao exame de peças e documentos, é preciso verificar a natureza da perícia, pois em alguns casos específicos os trabalhos podem ser prejudicados com o decurso do tempo. É o exemplo da pesquisa de recentidade de disparo em armas de fogo.

Da mesma forma, os levantamentos de local e a maior parte das perícias médicas, dificilmente fornecerão subsídios para um reexame direto, podendo, tão-somente, ser os laudos oficiais analisados e, eventualmente, criticados.

Por fim, a determinação legal poderá implicar na necessidade de os Institutos Médico-Legal e de Criminalística criarem centros de custódia para a guarda de materiais e peças que normalmente seriam remetidos à autoridade requisitante ${ }^{42}$.

\subsubsection{Número de peritos}

O número de peritos oficiais necessários para a realização da perícia foi matéria que causou discussão por longo tempo. A redação original do caput do art. 159 do Código de Processo Penal, falava em peritos, gerando polêmica sobre a necessidade de o exame ser efetuado por dois técnicos. Essa exigência descabida levou à criação da figura do segundo signatário, ou seja, do perito que, embora não tendo realizado qualquer exame, assinava o laudo a título de revisor, mero subscritor, em confiança, de trabalho alheio.

Posteriormente, a Lei $\mathrm{n}^{\circ}$ 8.862, de 28 de março de 1994, alterou o dispositivo mencionado e passou a exigir expressamente o concurso de dois peritos para a realização do exame, mandamento que, por total ausência de recursos humanos e materiais, nunca foi cumprido.

\footnotetext{
${ }^{42}$ Ver item 3.5.3: "A Lei n ${ }^{\circ}$ 11.690/08 e os centros de custódia".
} 
Finalmente, a Lei $n^{\circ} 11.690$, de 09 de junho de 2008, corrigiu a distorção, passando a admitir a realização da perícia por um único perito oficial, portador de diploma de curso superior:

\section{CPP}

Art. 159. O exame de corpo de delito e outras perícias serão realizados por perito oficial, portador de diploma de curso superior (Redação dada ao $\S 1^{\circ}$ pela Lei no 11.690 , de 09/06/08).

Por outro lado, se houver nomeação de peritos não oficiais ( $a d$ hoc), nos termos do $\S 1^{\circ}$ do art. 159 do Código de Processo Penal, o número de peritos deverá ser necessariamente de dois, sob pena de nulidade, conforme a Súmula 361 do STF:

\section{STF}

Súmula 361: No processo penal, é nulo o exame realizado por um só perito, considerando-se impedido o que tiver funcionado, anteriormente, na diligência da apreensão.

Outra novidade, introduzida pela Lei $\mathrm{n}^{0}$ 11.690, de 09 de junho de 2008, à semelhança do que ocorre no juízo cível, foi a possibilidade expressa de atuação de mais de um perito oficial e indicação de mais de um assistente técnico, em caso de perícia complexa, envolvendo mais de uma área de conhecimento especializado:

CPP - Art. 159....

$\S 7^{\circ}$ Tratando-se de perícia complexa que abranja mais de uma área de conhecimento especializado, poder-se-á designar a atuação de mais de um perito oficial, e a parte indicar mais de um assistente técnico.

A disposição, cópia do art. 431-B do Código de processo Civil, era despicienda, até porque a regra do processo penal é a perícia fragmentada, realizada por vários expertos, conforme suas especialidades.

\subsubsection{Prazos para realização da perícia}

No processo penal, o prazo para realização da perícia (ou do exame de corpo de delito) há de ser forçosamente curto. Velho brocardo utilizado pelos peritos criminais dá bem a idéia da importância de um exame célere: "o tempo que passa é a verdade que foge". 
Nesse sentido, a disposição dos arts. 6- e 161 do Código de Processo Penal:

\section{CPP}

Art. $6^{\circ}$ Logo que tiver conhecimento da prática da infração penal, a autoridade policial deverá:

I - dirigir-se ao local, providenciando para que não se alterem o estado e conservação das coisas, até a chegada dos peritos criminais;

$\cdots$

VII - determinar, se for caso, que se proceda a exame de corpo de delito e a quaisquer outras perícias;

Art. 161. O exame de corpo de delito poderá ser feito em qualquer dia e a qualquer hora.

Os únicos prazos para a realização da perícia, fixados no Código de Processo Penal, são, na verdade, prazos mínimos, de 6 horas para a realização do exame necroscópico (art. 162, caput, do CPP) e de 30 dias para a realização do exame complementar de classificação das lesões corporais (art. 168, § 2º, do CPP).

\section{CPP}

Art. 162. A autópsia será feita pelo menos seis horas depois do óbito, salvo se os peritos, pela evidência dos sinais de morte, julgarem que possa ser feita antes daquele prazo, o que declararão no auto.

Art. 168....

$\S 2^{\circ}$ Se o exame tiver por fim precisar a classificação do delito no art. $129, \S 1^{\circ}$, I, do Código Penal, deverá ser feito logo que decorra o prazo de trinta dias, contado da data do crime.

Os assistentes técnicos devem realizar seus exames, em regra, após a sua admissão pelo juiz e depois da conclusão dos exames e elaboração do laudo pelos peritos oficiais, o que recomenda a celeridade dos trabalhos, especialmente em se tratando de processo em que há réu preso.

CPP

Art. $159 . .$.

$\S 4^{\circ} \mathrm{O}$ assistente técnico atuará a partir de sua admissão pelo juiz e após a conclusão dos exames e elaboração do laudo pelos peritos oficiais, sendo as partes intimadas dessa decisão ( $\$ 4^{\circ}$ acrescido pela Lei $n^{\circ} 11.690$, de 09/06/08). 
No Código de Processo Civil, por outro lado, não há prazo fixado para a realização dos exames, mas apenas a data limite para entrega dos trabalhos, determinada pelo juiz, até porque, como hábito, as postulações são levadas ao juízo cível sempre bem depois dos acontecimentos.

\subsubsection{Prazos para entrega dos relatórios}

Para a entrega dos relatórios o CPP estabelece o prazo genérico de 10 dias (art. 160, parágrafo único).

CPP

Art. $160 . \ldots$

Parágrafo único. O laudo pericial será elaborado no prazo máximo de dez dias, podendo este prazo ser prorrogado, em casos excepcionais, a requerimento dos peritos.

Há prazos especiais, como, por exemplo, aquele designado pelo juiz para a verificação da cessação da periculosidade (art. 777, $\S 2^{\circ}$, do CPP) ou o do exame decorrente do incidente de insanidade (art. $150, \S 1^{\circ}$, do CPP), que não pode ultrapassar 45 dias.

Os assistentes técnicos devem apresentar seus pareceres em prazo fixado pelo juiz ou ser inquiridos em audiência (art. 159, § 5º, II, do CPP).

CPP

Art. $159 . .$.

$\S 5^{\circ}$ Durante o curso do processo judicial é permitido às partes, quanto à perícia:

II - Indicar assistentes técnicos que poderão apresentar pareceres em prazo a ser fixado pelo juiz ou ser inquiridos em audiência $\left(\S 5^{\circ}\right.$ acrescido pela Lei ${ }^{\circ} 11.690$, de 09/06/08).

No Código de Processo Civil os prazos são fixados pelo juiz, que deverá atentar para a data da audiência de instrução e julgamento (arts. 421 e 433 do CPC), tendo os assistentes técnicos 10 dias a mais para a apresentação de seus pareceres, depois de 
intimadas as partes da apresentação do laudo (art. 433, parágrafo único, do CPC).

\subsection{Relatórios periciais}

O resultado dos exames periciais é, geralmente, exarado sob a forma de relatórios periciais, criminalísticos ou médico-legais. A expressão relatório é utilizada para englobar, genericamente, o auto e o laudo pericial.

A maioria dos autores não aponta diferenças essenciais entre as espécies. Para eles, se o relatório for ditado ao escrivão ou escrevente, na presença da autoridade, policial ou judiciária, será chamado de auto pericial. Se, por outro lado, for elaborado posteriormente pelo próprio perito, estaremos diante do laudo pericial.

Zarzuela, Matunaga e Thomaz entendem que as divergências são mais significativas.

Segundo os renomados autores, auto pericial é:

"O documento processual oficial que se caracteriza pela urgência da apresentação de quem o requisita... . É um documento que se baseia em fato atual, não passado, representando modalidade de relatório elaborado pelos peritos que, à medida que realizam o exame pericial, ditam ao escrevente suas observações, interpretações e conclusões" enquanto o laudo pericial "constitui um documento processual oficial que se caracteriza por ser uma peça retrospectiva, isto é, referente a fatos passados, sejam infrações penais ou irrelevantes penais, cabendo aos peritos definir se o evento tem ou não interesse à justiça." ${ }^{43}$

Um bom exemplo de auto pericial é o decorrente do exame realizado por peritos leigos (art. 179 do CPP).

\section{CPP}

Art. 179. No caso do $\S 1^{\circ}$ do art. 159 , o escrivão lavrará o auto respectivo, que será assinado pelos peritos e, se presente ao exame, também pela autoridade.

Art. 159. ...

$\S 1^{\circ}$. Na falta de perito oficial, o exame será realizado por 2 (duas) pessoas idôneas, portadoras de diploma de curso superior preferencialmente na área específica, dentre as que tiverem habilitação

\footnotetext{
${ }^{43}$ ZARZUELA, José Lopes; MATUNAGA, Minoru; THOMAZ, Pedro Lourenço. op. cit. p. 321.
} 
técnica relacionada com a natureza do exame ( $\$ 1^{\circ}$ com redação alterada pela Lei $n^{\circ} 11.690$, de 09/06/08).

\subsubsection{Pareceres ou consultas - perícia extrajudicial}

Também conhecidos como perícia extrajudicial, os pareceres ou consultas, por sua vez, são documentos de cunho processual oficioso, elaborados por especialistas na matéria e cuja finalidade pode ser o esclarecimento de questão técnica discutida em juízo ou a emissão de juízo de valor sobre auto ou laudo pericial existente.

"Um trabalho dessa natureza possui o valor de simples parecer técnico. Como elemento de prova, será estimado pelo juiz, de maneira muito relativa, pois os dados colhidos para as considerações nele contidas resultam de operações extraprocessuais, que não podem prevalecer sobre os elementos probatórios e indiciários colhidos no curso da instância, ou, mesmo, na fase investigatória do inquérito, desde que existentes em laudos de peritos oficiais. As conclusões e explanações de ordem científica, ali contidas, o juiz as examinará como peritus peritorum, dando-lhes o valor que entender merecerem. Para tanto, será fator de sumo relevo, sem dúvida alguma, a idoneidade do perito e a sua nomeada científica." 44

A ausência do auto ou laudo pericial pode levar à nulidade do feito. A ausência de parecer ou consulta não acarreta qualquer nulidade, até porque seu subscritor não se submete ao crime de falsa perícia (art. 342 do CP).

O quadro a seguir, resume as diferenças entre as três espécies de documentos processuais criminalísticos:

\begin{tabular}{|l|l|l|}
\hline \multicolumn{1}{|c|}{ Laudo pericial } & \multicolumn{1}{c|}{ Auto pericial } & \multicolumn{1}{c|}{ Parecer ou consulta } \\
\hline Tem caráter oficial. & Tem caráter oficial. & Tem caráter oficioso. \\
\hline $\begin{array}{l}\text { Deve ser elaborado por perito } \\
\text { oficial legalmente habilitado. }\end{array}$ & $\begin{array}{l}\text { Deve ser elaborado por perito } \\
\text { oficial legalmente habilitado. }\end{array}$ & $\begin{array}{l}\text { Não reclamam habilitação legal } \\
\text { de seu subscritor. }\end{array}$ \\
\hline É elaborado por escrito. & É elaborado verbalmente. & É elaborado por escrito. \\
\hline $\begin{array}{l}\text { A falta injustificada pode levar à } \\
\text { nulidade do feito. }\end{array}$ & $\begin{array}{l}\text { A falta injustificada pode levar à } \\
\text { nulidade do feito. }\end{array}$ & $\begin{array}{l}\text { Não existe qualquer nulidade } \\
\text { decorrente de sua ausência nos } \\
\text { autos. }\end{array}$ \\
\hline Refere-se a fato pretérito. & Refere-se a fato presente. & $\begin{array}{l}\text { Não objetiva a descrição de } \\
\text { fatos, mas apenas a analise } \\
\text { técnica de uma questão ou a } \\
\text { crítica a um auto ou laudo já } \\
\text { existente. }\end{array}$ \\
\hline
\end{tabular}

\footnotetext{
${ }^{44}$ MARQUES, José Frederico. Elementos de direito processual penal. 2. ed. atual. Campinas, SP:
} Millennium, 2000. v. 2, p. 433. 


\begin{tabular}{|l|l|l|}
\hline $\begin{array}{l}\text { Pede a observância de prazos } \\
\text { processuais. }\end{array}$ & Caracteriza-se pela celeridade. & $\begin{array}{l}\text { Não nenhuma } \\
\text { celeridade. }\end{array}$ \\
\hline $\begin{array}{l}\text { A elaboração do laudo é } \\
\text { posterior à realização do exame. }\end{array}$ & $\begin{array}{l}\text { A elaboração do auto é } \\
\text { concomitante à realização do } \\
\text { exame. }\end{array}$ & Não há prazo para sua conclusão. \\
\hline $\begin{array}{l}\text { Permite a apresentação de } \\
\text { quesitos. }\end{array}$ & Não contém quesitos. & $\begin{array}{l}\text { Permite a formulação de } \\
\text { quesitos. }\end{array}$ \\
\hline É mais elaborado que o auto. & É mais sucinto que o laudo. & $\begin{array}{l}\text { É mais complexo, em geral, que } \\
\text { o laudo ou o auto pericial. }\end{array}$ \\
\hline $\begin{array}{l}\text { Exige um maior formalismo em } \\
\text { sua apresentação. }\end{array}$ & $\begin{array}{l}\text { Embora não exija formalismo, } \\
\text { tem, em regra, } \\
\text { maior } \\
\text { complexidade estrutural. }\end{array}$ \\
\hline
\end{tabular}

\subsubsection{Partes constitutivas do auto e do laudo pericial}

Os Códigos de Processo Penal e Civil não estabelecem normas a respeito da estrutura do auto ou laudo pericial, ficando inteiramente ao arbítrio dos peritos a escolha da melhor forma de apresentação de seus trabalhos.

Para Galdino Siqueira ${ }^{45}$, o auto deve conter três partes: preâmbulo ou cabeçalho, o histórico (subdividido em comemorativos ou anamnese e visum et repertum) e conclusões.

Para Antonio Bento de Faria ${ }^{46}$ o relatório (auto ou laudo) deve ser composto de cinco partes, o preâmbulo, os comemorativos ou anamnese, a descrição dos fatos (visum et repertum), a discussão dos fatos e as conclusões.

Atualmente, entretanto, os autos e laudos periciais são um pouco mais complexos, e podem apresentar as seguintes partes:

a) preâmbulo ou intróito - em que o perito fornece dados gerais como dia, mês e hora do exame, local em que foi realizada a perícia, autoridade requisitante, objeto do trabalho, natureza da infração, etc.;

b) histórico ou anamnese - em que é elaborado um breve resumo da ocorrência e de seus antecedentes, inclusive com informações colhidas no local ou intercorrências observadas durante os trabalhos e que possam ser de interesse pericial;

c) descrição dos trabalhos - parte mais importante do laudo, em que o perito relata minuciosamente todas as etapas do exame, inclusive a metodologia utilizada. Ela

\footnotetext{
${ }^{45}$ SIQUEIRA, Galdino. Curso de processo criminal. 2. ed. São Paulo: Livraria e Officinas Magalhães, 1917. p. 237.

${ }^{46}$ FARIA, Antonio Bento de. Código de Processo Penal. 2. ed. Rio de Janeiro: Record, 1960. v. 1, p. 265.
} 
representa o visum et repertum et interpretatum que constitui o cerne e o objetivo final da perícia;

d) discussão - parte do laudo nem sempre presente, em que os peritos tecem alguns comentários relacionados com os achados do exame. Bento de Faria adverte que, ao discutir o exame, o perito deve ter o cuidado de não obscurecer suas conclusões e afirmações essenciais, nem comprometer a prova ${ }^{47}$.

Um bom exemplo de conclusão possível é a determinação constante do art. 169, parágrafo único, do CPP, para que os peritos registrem no laudo as alterações do estado das coisas e discutindo no relatório, as conseqüências dessas alterações na dinâmica dos fatos;

e) conclusões - as conclusões não se confundem com as respostas aos quesitos, porque mais amplas que estas. Ao finalizar seu trabalho, o perito pode e deve relatar as conseqüências lógicas que dele advieram e que entender pertinentes, sem se ater, necessariamente, às questões formuladas pelas partes ou pelo magistrado;

f) respostas aos quesitos - neste tópico os peritos devem responder de forma objetiva aos quesitos oficiais e oficiosos, quando existentes ou formulados;

g) fecho ou encerramento - em que se acham indicados o número de páginas, as assinaturas dos peritos que atuaram no caso e a relação de eventuais anexos (desenhos, gráficos e fotografias).

É bom lembrar que não há qualquer disposição legal ou administrativa quanto à estrutura do laudo, cabendo ao redator a decisão sobre a forma mais produtiva.

\subsubsection{Anexos do laudo pericial}

Com a finalidade precípua de ilustrar o laudo pericial, os peritos podem e devem fazê-lo acompanhar de alguns anexos.

O Código de Processo Penal prevê expressamente a possibilidade de o laudo ser instruído por fotografias, microfotografias ${ }^{48}$, desenhos e esquemas elucidativos ${ }^{49}$.

\footnotetext{
${ }^{47}$ FARIA, Antonio Bento de. op. cit., p. 265.

${ }^{48}$ Fotografia e microfotografia judiciária.

${ }^{49}$ Os desenhos e esquemas integram a topografia judiciária, que tem por objetivo suprir as deficiências da fotografia quando é necessário um levantamento de local com precisão matemática ou quando é preciso ilustrar a dinâmica de algum evento.
} 


\section{CPP}

Art. 165. Para representar as lesões encontradas no cadáver, os peritos, quando possível, juntarão ao laudo do exame provas fotográficas, esquemas ou desenhos, devidamente rubricados.

Art. 169. Para o efeito de exame do local onde houver sido praticada a infração, a autoridade providenciará imediatamente para que não se altere o estado das coisas até a chegada dos peritos, que poderão instruir seus laudos com fotografias, desenhos ou esquemas elucidativos.

Art. 170. Nas perícias de laboratório, os peritos guardarão material suficiente para a eventualidade de nova perícia. Sempre que conveniente, os laudos serão ilustrados com provas fotográficas, ou microfotográficas, desenhos ou esquemas (grifos nossos).

O Código de Processo Civil menciona plantas, desenhos, fotografias ou quaisquer outras peças.

\section{$\mathrm{CPC}$}

Art. 429. Para o desempenho de sua função, podem o perito e os assistentes técnicos utilizar-se de todos os meios necessários, ouvindo testemunhas, obtendo informações, solicitando documentos que estejam em poder da parte ou em repartições públicas, bem como instruir o laudo com plantas, desenhos, fotografias e outras quaisquer peças (grifos nossos).

O dispositivo, na verdade, abre a possibilidade de o perito ilustrar, em sentido amplo, o seu trabalho com toda a sorte de elementos acessórios. Ao mencionar a fórmula casuística, "plantas, desenhos, fotografias", seguida da genérica, "e outras quaisquer peças", abre o legislador um leque de opções que inclui a juntada de filmes, maquetes, moldes, mídia magnética e outras, desde que praticáveis e úteis à demonstração das conclusões exaradas no trabalho pericial.

\subsubsection{Quesitos}

Quesitos são perguntas específicas, dirigidas pelo juiz ou pelas partes aos peritos, objetivando esclarecer determinado ponto referente ao exame realizado. Além de ajudar a aclarar pontos obscuros, servem de orientação ao perito para a elaboração de seu relatório, uma vez que terá de dirigir seus trabalhos no sentido de responder às questões formuladas. 
Não se pode esquecer que os peritos, embora especialistas na sua área de atuação, não têm, em regra, conhecimento jurídico. Daí a necessidade de que respondam a determinadas perguntas, relevantes para o Direito, mas aparentemente sem importância para um técnico de outra área do saber humano.

\subsubsection{Classificação dos quesitos}

No que toca ao momento de sua formulação, os quesitos classificam-se em: originários, suplementares ou complementares.

Originários são os que antecedem à perícia, formulados como orientação ao técnico para a realização dos exames.

Suplementares são aqueles apresentados após os originários e até mesmo durante a realização dos exames, objetivando suprir alguma deficiência constatada nos primeiros.

Complementares são os apresentados após a realização dos exames e entrega do laudo, visando esclarecer dúvidas ou complementar o trabalho pericial realizado.

Quanto à sua origem, os quesitos podem ser oficiais (de praxe), legais ou oficiosos (não oficiais).

Oficiais ou de praxe são aqueles que, embora não tendo sido apresentados pelas partes, e não havendo previsão legal de sua formulação, integram habitualmente os laudos periciais, constando dos impressos próprios relativos a cada espécie de perícia realizada.

Legais são os previstos expressamente na lei processual. Não são quesitos propriamente ditos, porque não constituem perguntas diretas que devem ser respondidas objetivamente pelos técnicos. São, isto sim, esclarecimentos que a lei determina devem ser dados pelos peritos em alguns casos. Como exemplos, temos os art. 171 a 174 do Código de Processo Penal.

Quesitos oficiosos (não oficiais) são os apresentados pelo juiz ou pelas partes conforme a natureza do caso.

A Lei $n^{\circ} 11.690$, de 09 de junho de 2008 , acrescentou o $\S 5^{\circ}$ ao art. 159 , que, em seu inciso I, explicitou a possibilidade de as partes requererem a oitiva dos peritos para responder a quesitos (oficiosos) ou prestar esclarecimentos sobre a prova. 


\section{CPP}

Art. $159 . .$.

$\S 5^{\circ}$ Durante o curso do processo judicial, é permitido às partes, quanto à perícia:

I - requerer a oitiva dos peritos para esclarecerem a prova ou para responderem a quesitos, desde que o mandado de intimação e os quesitos ou questões a serem esclarecidas sejam encaminhados com antecedência mínima de 10 (dez) dias, podendo apresentar as respostas em laudo complementar ( $\$ 5^{\circ}$ acrescido pela Lei $n^{\circ} 11.690$, de 09/06/08).

Quesitos, como vimos, são perguntas objetivas, diretas, que versam sobre pontos específicos do trabalho pericial, enquanto esclarecimentos são explicações mais amplas, destinadas a elucidar algum ponto obscuro ou mesmo complementar o exame realizado.

Embora a oitiva dos peritos e a apresentação de questões complementares seja prática relativamente comum no processo penal (art. 176), a novidade fica por conta da necessidade de encaminhamento prévio das inquirições com antecedência mínima de 10 (dez) dias.

Note-se que os peritos podem ser intimados a comparecer em juízo para prestar esclarecimentos ou responder às questões, facultada a apresentação das respostas e informações sob a forma de laudo complementar.

$\mathrm{Na}$ área cível não há quesitos oficiais ou legais, mas tão-somente os oficiosos, formulados livremente pelo juiz e pelas partes de acordo com as particularidades específicas do caso. De qualquer modo, o perito e o assistente técnico só estarão obrigados a prestar os esclarecimentos solicitados quando intimados 5 (cinco) dias antes da audiência (art. 435 do CPC).

\section{CPC}

Art. 435. A parte, que desejar esclarecimento do perito e do assistente técnico, requererá ao juiz que mande intimá-lo a comparecer à audiência, formulando desde logo as perguntas, sob forma de quesitos.

Parágrafo único. O perito e o assistente técnico só estarão obrigados a prestar os esclarecimentos a que se refere este artigo, quando intimados 5 (cinco) dias antes da audiência.

Por último, no que concerne à validade, os quesitos podem ainda ser pertinentes ou impertinentes, conforme sejam convenientes ou não ao esclarecimento dos fatos. Os 
quesitos impertinentes, eventualmente apresentados pelas partes, devem ser indeferidos pelo magistrado (art. 426, I, do CPC, aplicável por analogia ao processo penal, omisso):

\section{$\mathrm{CPC}$}

Art. 426. Compete ao juiz:

I - indeferir quesitos impertinentes;

\subsection{Outros documentos processuais da medicina legal}

Além dos relatórios periciais, são também documentos médico-legais ou médicojudiciários todas as informações de conteúdo médico, apresentadas por médico, quer por simples exposição verbal, quer por intermédio de trabalho escrito, que possam servir como prova pré-constituída ou como prova do ato neles representado ${ }^{50}$.

São características de todos os documentos médico-legais:

- $\quad$ ser elaborado por médico habilitado ${ }^{51}$ conforme a legislação vigente ${ }^{52}$;

- decorrer de exame que corresponda a ato médico específico ${ }^{53}$, assim entendido aqueles próprios do exercício da medicina ${ }^{54}$, com exceção dos pareceres, onde o profissional poderá valer-se de doutrina pré-existente;

- ser apresentado verbalmente ou mediante um documento escrito;

${ }^{50}$ CROCE, Delton; CROCE JÚNIOR, Delton. Manual de medicina legal. 5. ed., rev. e ampl. São Paulo: Saraiva, 2004. p. 27.

${ }^{51}$ Lembra Guilherme Oswaldo Arbenz (Medicina legal e antropologia forense. Rio de Janeiro: Atheneu, 1988. p. 27) que a habilitação para o exercício da medicina implica na habilitação profissional, que se concretiza pela posse de um título universitário de graduação idôneo, e pela habilitação legal, consubstanciada pelos registros nas repartições públicas competentes: a) no Ministério da Educação e no Ministério da Saúde; b) inscrição no respectivo Conselho regional de Medicina; e c) inscrição no cadastro de contribuintes da municipalidade; previdência social e Cadastro de Pessoa Física (CPF), etc.

${ }^{52} \mathrm{~A}$ Lei $\mathrm{n}^{\mathrm{o}} 3.268$, de 30 de setembro de 1957 (alterada pela Lei $\mathrm{n}^{\circ} 11.000$, de 15 de dezembro de 2004), modificou a estrutura dos Conselhos Federal e Regionais de Medicina, aos quais cabe a fiscalização e a regulamentação da profissão médica.

${ }^{53}$ Dirigido a uma pessoa ou a uma coletividade.

${ }^{54} \mathrm{~A}$ Resolução do CFM no $1.627 / 2001$, define, em seu art. $1^{\circ}$, o ato profissional de médico (ato médico) como todo procedimento técnico-profissional praticado por médico legalmente habilitado e dirigido para: a) a promoção da saúde e prevenção da ocorrência de enfermidades ou profilaxia (prevenção primária); b) a prevenção da evolução das enfermidades ou execução de procedimentos diagnósticos ou terapêuticos (prevenção secundária); c) a prevenção da invalidez ou reabilitação dos enfermos (prevenção terciária).

Genival França conceitua ato médico específico como "a utilização de meios e recursos para prevenir a doença, recuperar e manter a saúde do ser humano ou da coletividade, inseridos nas normas técnicas e no conhecimento científico adquiridos nos cursos regulares de medicina e aceitos pelos órgãos competentes, estando quem o executa, supervisiona ou solicita, profissional e legalmente habilitado" (FRANÇA, Genival Veloso de. Medicina legal. 5. ed. Rio de Janeiro: Guanabara Koogan, 1998. p. 376). 
- ter por finalidade esclarecer alguma questão colocada para apreciação da Justiça.

Genericamente considerados, os documentos médico-legais englobam os relatórios médico-legais, os pareceres e os depoimentos orais (já analisados), os atestados ou certificados médicos e as notificações compulsórias.

Atestados $^{55}$ ou certificados médicos são informações simples, prestadas por escrito sobre um determinado fato de interesse médico, assim como sobre suas possíveis conseqüências ou desdobramentos. Subdividem-se em atestados clínicos, atestados para internação compulsória (também chamados de notificações), atestados para fins previdenciários e atestados de óbito.

Os atestados clínicos são declarações de cunho médico, prestadas de maneira sucinta e objetiva por profissional habilitado, com múltiplas finalidades, entre as quais certificar a existência de algum quadro mórbido, intervenções cirúrgicas e suas conseqüências ou para justificar ausência ao trabalho. A validade jurídica de tais atestados, exatamente pela ausência de formalidades, é questionável, servindo apenas como princípio de prova de fatos de relevância relativa.

Atestados para fins previdenciários são aqueles destinados a comprovar determinado estado patológico especificamente perante a Previdência Social (infortunística), que, para a concessão de qualquer benefício, exige o diagnóstico.

Para contornar o problema do sigilo, o médico indica o quadro clínico do paciente utilizando uma codificação especial, de acordo com a Classificação Estatística Internacional de Doenças e Problemas Relacionados à Saúde (CID-10), publicada pela OMS - Organização Mundial de Saúde ${ }^{56}$.

Notificações compulsórias são comunicações obrigatórias que devem ser feitas pelo médico, ou por outros profissionais de saúde, para as autoridades competentes, por razões políticas, legais, sociais ou sanitárias. São elas:

- doenças de notificação compulsória ${ }^{57}$;

- $\quad$ comunicação de acidente do trabalho - $\mathrm{CAT}^{58}$;

\footnotetext{
${ }^{55}$ Do latim attestatus, particípio de attestor (dar testemunho, comprovar).

${ }^{56}$ Atualmente vigora a $10^{\mathrm{a}}$ revisão - CID 10 - aprovada pela Conferência Internacional para a Décima Revisão, em 1989, e adotada pela Quadragésima Terceira Assembléia Mundial da Saúde.

${ }^{57}$ Lei $\mathrm{n}^{\mathrm{o}} 6.259$, de 30 de outubro de 1975, Decreto $\mathrm{n}^{\circ} 78.231$, de 12 de agosto de 1976 e Portaria SVS/MS n ${ }^{\circ}$ 33, de 14 de julho de 2005.

${ }^{58}$ Art. 169 da CLT.
} 
- comunicação de crime de ação penal pública incondicionada de que teve ciência no exercício da medicina ${ }^{59}$;

- comunicação da ocorrência de morte encefálica ${ }^{60}$;

- óbitos ou lesões à saúde produzidos por não médicos ${ }^{61}$;

- violência contra a mulher atendida em serviço de saúde ${ }^{62}$;

- esterilizações cirúrgicas $^{63}$;

- maus-tratos contra criança ou adolescente ${ }^{64}$;

- maus-tratos contra idoso ${ }^{65}$;

- intercorrência envolvendo pessoa portadora de deficiência internada ${ }^{66}$;

- tortura $^{67}$.

\subsubsection{Declarações ou atestados de óbito}

O Código Civil, em seu art. $6^{\circ}$, estabelece que "a existência da pessoa humana termina com a morte", devendo a ocorrência ser inscrita em registro público (art. $9^{\circ}, \mathrm{I}$, do $\mathrm{CC})$.

$\mathrm{CC}$

Art. $6^{\circ}$ A existência da pessoa natural termina com a morte; presume-se esta, quanto aos ausentes, nos casos em que a lei autoriza a abertura de sucessão definitiva.

Art. $9^{\circ}$ Serão registrados em registro público:

I - os nascimentos, casamentos e óbitos;

\footnotetext{
${ }^{59}$ Decreto-lei no 3.688 , de 3 de outubro de 1941 (Lei das Contravenções Penais), art. 66, II.

${ }^{60}$ Lei no 9.434 , de 4 de fevereiro de 1997 (Transplantes de Órgãos), arts. 13 e 22.

${ }^{61}$ Resolução no 1.641, de 12 de julho de 2002, do Conselho Federal de Medicina.

${ }^{62}$ Lei ${ }^{\circ} 10.778$, de 24 de novembro de 2003, art. $1^{\circ}$.

${ }^{63}$ Lei no ${ }^{\circ} .263$, de 12 de janeiro de 1996 (Planejamento Familiar), art. 11.

${ }^{64}$ Lei no ${ }^{\circ} 8069$, de 13 de julho de 1990 (Estatuto da Criança e do Adolescente), art. 13.

${ }^{65}$ Lei $\mathrm{n}^{\circ} 10.741$, de $1^{\circ}$ de outubro de 2003 (Estatuto do Idoso), art. 19.

${ }^{66}$ Lei n ${ }^{\circ} 10.216$, de 06 de abril de 2001.

${ }^{67}$ Resolução CFM n ${ }^{\circ}$ 1.246/88 (Código de Ética Médica), art. 53, parágrafo único.
} 
A lavratura do assento de óbito é formalidade exigida, inclusive, para o próprio sepultamento, nos termos do que dispõe o art. 77 da Lei 6.015, de 31 de dezembro de 1973 (Lei dos Registros Públicos):

Lei 6.015/73

Art. 77. Nenhum sepultamento será feito sem certidão, do oficial de registro do lugar do falecimento, extraída após a lavratura do assento de óbito, em vista do atestado de médico, se houver no lugar, ou, em caso contrário, de duas pessoas qualificadas que tiverem presenciado ou verificado a morte.

Para que o assento de óbito possa ser anotado no respectivo cartório de registro civil, é indispensável a apresentação da declaração ou atestado de óbito ${ }^{68}$, devidamente assinada por médico, o que só é dispensável se a morte for natural e não existir profissional na comunidade que possa fornecer o documento (art. 77 da Lei 6.015/73).

As finalidades das declarações de óbito são três ${ }^{69}$ :

a) firmar a realidade da morte;

b) fornecer elementos para a estatística demográfico-sanitária ${ }^{70}$; e

c) esclarecer a causa jurídica do evento.

Para que possa atender a essas finalidades, a declaração deve conter, além dos dados de qualificação da pessoa falecida, no mínimo, a causa imediata da morte (por exemplo, anemia aguda); a causa conseqüencial que levou ao óbito (oriunda de ferimento transfixante no coração) e a causa básica (produzido por projétil de arma de fogo $)^{71}$.

\footnotetext{
${ }^{68}$ Alguns autores, como Hygino de Carvalho Hércules, preferem a denominação declaração de óbito porque adotada pela Sexta Revisão da Classificação Internacional de Doenças (in GOMES, Hélio. Medicina legal. 33. ed. Atualizada por Hygino de Carvalho Hércules. Rio de Janeiro: Freitas Bastos, 2003. p. 37).

${ }^{69}$ ARBENZ, Guilherme Oswaldo. op. cit., p. 32.

${ }^{70}$ Em âmbito nacional, a estatística é elaborada pelo Sistema de Informações sobre Mortalidade - SIM, "criado pelo Ministério da Saúde, em 1975, para a obtenção regular de dados sobre mortalidade, de forma abrangente e confiável, para subsidiar as diversas esferas de gestão do sistema para a análise de situação, planejamento e avaliação das ações e programas de saúde. O sistema proporciona a produção de estatísticas de mortalidade e a construção dos principais indicadores de saúde, permitindo estudos não apenas do ponto de vista estatístico e epidemiológico, mas também sócio-demográfico. O documento-padrão para captação de dados sobre mortalidade, em todo o país, é a Declaração de Óbito - DO, que é o resultado da padronização, efetuada em 1975, dos mais de quarenta modelos diferentes de Atestado de Óbito, então em uso. O layout atual decorre de alterações sofridas desde então, com inclusão ou alterações de variáveis, de modo a adequá-lo à atualidade epidemiológica." (fonte: MINISTÉRIO DA SAÚDE. Portal da Saúde. Disponível em <www.dtr2001.saude.gov.br/svs/sis/sis00 sim.htm>. Acesso em: 10 nov. 2006).

${ }^{71}$ Hygino de Carvalho Hércules (in GOMES, Hélio. op. cit., p. 39).
} 
Juridicamente, a morte pode ser natural, violenta (não natural) e suspeita. Será considerada violenta quando decorrer da ação de energias externas, ainda que tardiamente, assumindo a forma de acidente, suicídio ou crime $^{72}$. Será suspeita se ocorrer de forma inesperada, provocada por causa não evidente.

De acordo com a origem, os atestados ou declarações de óbito podem ser clínicos ou oficiais.

$$
\text { Atestados ou declarações de óbito }\left\{\begin{array}{l}
\text { clínicos - morte natural assistida } \\
\text { oficiais }\left\{\begin{array}{l}
\text { morte natural não assistida } \\
\text { morte violenta }\left\{\begin{array}{l}
\text { acidental } \\
\text { suicida } \\
\text { criminosa }
\end{array}\right.
\end{array}\right.
\end{array}\right.
$$

O atestado clínico é reservado para a hipótese de morte natural com assistência médica. Nesse caso, a lavratura da declaração é obrigação ética do médico, nos termos do art. 115 do Código de Ética Médica, preferencialmente pelo profissional que vinha acompanhando o caso (art. $2^{\circ}, 1$, II, $a$, da Resolução $n^{\circ}$ 1.779/05 do Conselho Federal de Medicina).

Se o paciente estava internado sob regime hospitalar, o atestado pode ser assinado pelo médico assistente ou por um substituto da Unidade Notificadora da instituição (art. $2^{\circ}$, 1, II, $b$, da Resolução n ${ }^{\circ}$ 1.779/05 do Conselho Federal de Medicina).

No caso de tratamento sob regime ambulatorial, a declaração deve ser lavrada pelo profissional designado pela instituição, que prestava assistência ao paciente, ou pelo SVO (art. $2^{\circ}, 1$, II, $c$, da Resolução n ${ }^{\circ}$ 1.779/05 do Conselho Federal de Medicina).

A declaração de óbito do paciente em tratamento sob regime domiciliar (Programa Saúde da Família, internação domiciliar homecare e outros) deverá ser fornecida pelo médico pertencente ao programa ao qual o paciente estava cadastrado, ou pelo SVO, caso o médico não consiga correlacionar o óbito com o quadro clínico concernente ao acompanhamento do paciente (art. $2^{\circ}, 1$, II, $d$, da Resolução $n^{\circ}$ 1.779/05 do Conselho Federal de Medicina).

${ }^{72}$ GOMES, Hélio. op. cit., p. 39. 
Na hipótese de "morte fetal os médicos que prestaram assistência à mãe ficam obrigados a fornecer a declaração de óbito do feto, quando a gestação tiver duração igual ou superior a 20 semanas ou o feto tiver peso corporal igual ou superior a 500 (quinhentos) gramas e/ou estatura igual ou superior a 25 cm" (art. $2^{\circ}$, 2, da Resolução no 1.779/05 do Conselho Federal de Medicina). A disposição refere-se à chamada morte fetal tardia. As perdas precoces são consideradas aborto e não implicam na lavratura de declaração de óbito.

Sendo a morte natural, mas desassistida, violenta ou suspeita (não natural), o médico não poderá fornecer o atestado.

Nas mortes naturais não assistidas o corpo deve ser encaminhado de preferência para o Serviço de Verificação de Óbitos (SVO) ou, na sua falta, para os médicos do serviço público de saúde (art. $2^{\circ}$, 1, I, $a$ e $b$, da Resolução no 1.779/05 do Conselho Federal de Medicina).

Em se tratando de mortes violentas ou suspeitas, o corpo deve ser encaminhado ao Instituto Médico-Legal - IML, onde será realizada a necropsia e, eventualmente, exames complementares destinados a comprovar a causa mortis (art. $2^{\circ}, 3$, da Resolução $\mathrm{n}^{\circ}$ 1.779/05 do Conselho Federal de Medicina).

Também deverão ser encaminhados ao IML as ocorrências em que a morte possa ter decorrido de "alguma medida com intenção diagnóstica ou terapêutica indicada por agente não médico ou realizada por quem não esteja habilitado para fazê-lo" (art. $1^{\circ}$, da Resolução n $^{\circ}$.641, de 12 de julho de 2002, do Conselho Federal de Medicina).

Código de Ética Médica

É vedado ao médico:

Art. 114. Atestar óbito quando não o tenha verificado pessoalmente, ou quando não tenha prestado assistência ao paciente, salvo, no último caso, se o fizer como plantonista, médico substituto, ou em caso de necropsia e verificação médico-legal.

Art. 115. Deixar de atestar óbito de paciente ao qual vinha prestando assistência, exceto quando houver indícios de morte violenta. 
Resolução CFM n ${ }^{\circ}$ 1.779/05

Art. $1^{\circ} \mathrm{O}$ preenchimento dos dados constantes na Declaração de Óbito é da responsabilidade do médico que atestou a morte.

Art. $2^{\circ}$ Os médicos, quando do preenchimento da Declaração de Óbito, obedecerão às seguintes normas:

1) Morte natural:

I. Morte sem assistência médica:

a) Nas localidades com Serviço de Verificação de Óbitos (SVO):

A Declaração de Óbito deverá ser fornecida pelos médicos do SVO;

b) Nas localidades sem SVO :

A Declaração de Óbito deverá ser fornecida pelos médicos do serviço público de saúde mais próximo do local onde ocorreu o evento; na sua ausência, por qualquer médico da localidade.

II. Morte com assistência médica:

a) A Declaração de Óbito deverá ser fornecida, sempre que possível, pelo médico que vinha prestando assistência ao paciente.

b) A Declaração de Óbito do paciente internado sob regime hospitalar deverá ser fornecida pelo médico assistente e, na sua falta, por médico substituto pertencente à instituição.

c) A declaração de óbito do paciente em tratamento sob regime ambulatorial deverá ser fornecida por médico designado pela instituição que prestava assistência, ou pelo SVO;

d) A Declaração de Óbito do paciente em tratamento sob regime domiciliar (Programa Saúde da Família, internação domiciliar e outros) deverá ser fornecida pelo médico pertencente ao programa ao qual o paciente estava cadastrado, ou pelo SVO, caso o médico não consiga correlacionar o óbito com o quadro clínico concernente ao acompanhamento do paciente.

2) Morte fetal:

Em caso de morte fetal, os médicos que prestaram assistência à mãe ficam obrigados a fornecer a Declaração de Óbito quando a gestação tiver duração igual ou superior a 20 semanas ou o feto tiver peso corporal igual ou superior a 500 (quinhentos) gramas e/ou estatura igual ou superior a $25 \mathrm{~cm}$.

3) Mortes violentas ou não naturais:

A Declaração de Óbito deverá, obrigatoriamente, ser fornecida pelos serviços médico-legais.

Parágrafo único. Nas localidades onde existir apenas 1 (um) médico, este é o responsável pelo fornecimento da Declaração de Óbito.

Art. $3^{\circ}$ Esta resolução entra em vigor na data de sua publicação e revoga a Resolução $\mathrm{CFM} \mathrm{n}^{\circ} 1.601 / 00$.

\section{Resolução CFM n 1.641/02}

Art. $1^{\circ}$ É vedado aos médicos conceder declaração de óbito em que o evento que levou à morte possa ter sido alguma medida com intenção diagnóstica ou terapêutica indicada por agente não médico ou realizada por quem não esteja habilitado para fazê-lo, devendo, neste caso, tal fato ser comunicado à autoridade policial competente a fim de que o corpo possa ser encaminhado ao Instituto Médico-Legal para verificação da causa mortis. 
O Serviço de Verificação de Óbitos $(\mathrm{SVO})^{73}$ tem por finalidade determinar a causa mortis dos indivíduos falecidos sem assistência médica e dos falecidos de moléstia não perfeitamente definida ${ }^{74}$.

A existência dos Serviços de Verificação de Óbitos traz algumas vantagens ${ }^{75}$ :

a) evitam a inumação prematura;

b) eliminam as dúvidas sobre a identidade do cadáver;

c) fornecem elementos para os serviços de estatística;

d) apontam a causa exata da morte; e

e) aumentam as chances de descobrimento e esclarecimento de mortes criminosas.

Atribuição para atestar o óbito $\left\{\begin{array}{l}\text { do médico - mortes naturais assistidas } \\ \text { SVO }\left\{\begin{array}{l}\text { mortes naturais desassistidas } \\ \text { óbitos por moléstias mal definidas }\end{array}\right. \\ \mathrm{IML}-\text { mortes não naturais (violentas ou suspeitas) }\end{array}\right.$

Sejam clínicas ou oficiais, as declarações de óbito são impressas em três vias, prénumeradas seqüencialmente e distribuídas graciosamente pelo Ministério da Saúde às Secretarias Estaduais de Saúde e, por intermédio destas últimas, aos estabelecimentos de saúde, Institutos Médico-Legais, Serviços de Verificação de Óbitos, Médicos e Cartórios.

O quadro a seguir resume o destino das vias, nas várias hipóteses ${ }^{76}$ :

\footnotetext{
${ }^{73}$ A Portaria MS/GM no 1.405 , de 29 de junho de 2006, instituiu a Rede Nacional de Serviços de Verificação de Óbito e Esclarecimento de Causa Mortis (SVO).

${ }^{74}$ O Serviço de Verificação de Óbitos (SVO) da cidade de São Paulo foi regulamentado pelo Decreto $n^{\circ} 4.967$ de 13 de abril de 1931, modificado pela Lei $\mathrm{n}^{\circ} 10.095$ de 03 de maio de 1968, e pelo Decreto $\mathrm{n}^{\circ} 51.914$, de 5 de dezembro de 1968.

${ }^{75}$ ARBENZ, Guilherme Oswaldo. op. cit., p. 34.

${ }^{76}$ Fonte: MINISTÉRIO DA SAÚDE. Portal da Saúde. Disponível em <www.dtr2001.saude.gov.br/svs/sis/sis00 sim.htm>. Acesso em: 10 nov. 2006.
} 


\begin{tabular}{|c|c|c|c|}
\hline Hipótese & Quem atesta & Via & Destino \\
\hline \multirow{3}{*}{$\begin{array}{l}\text { Óbitos naturais fora dos } \\
\text { hospitais, mas com assistência. }\end{array}$} & \multirow{3}{*}{ O médico responsável } & $1^{\mathrm{a}}$ & Secretaria Municipal de Saúde. \\
\hline & & $2^{\mathrm{a}}$ & Representante da família. \\
\hline & & $3^{\mathrm{a}}$ & Secretaria Municipal de Saúde. \\
\hline \multirow{3}{*}{$\begin{array}{l}\text { Óbitos naturais ocorridos em } \\
\text { estabelecimentos de saúde. }\end{array}$} & \multirow{3}{*}{$\begin{array}{l}\text { O médico encarregado da } \\
\text { unidade }\end{array}$} & $1^{\mathrm{a}}$ & Secretaria Municipal de Saúde. \\
\hline & & $2^{\mathrm{a}}$ & Representante da família. \\
\hline & & $3^{\mathrm{a}}$ & Arquivamento no prontuário \\
\hline \multirow{3}{*}{ Óbitos naturais sem assistência. } & \multirow{3}{*}{ O médico do SVO } & $1^{\mathrm{a}}$ & Secretaria Municipal de Saúde \\
\hline & & $2^{\mathrm{a}}$ & Representante da família. \\
\hline & & $3^{\mathrm{a}}$ & Arquivamento no SVO \\
\hline \multirow{3}{*}{ Causas acidentais ou violentas. } & \multirow{3}{*}{$\begin{array}{l}\text { O médico-legista ou } \\
\text { perito designado }\end{array}$} & $1^{\mathrm{a}}$ & Secretaria Municipal de Saúde \\
\hline & & $2^{a}$ & Representante da família. \\
\hline & & $3^{a}$ & Arquivamento no IML \\
\hline
\end{tabular}

Nos óbitos naturais ocorridos em localidades em que não existe médico, o responsável pelo falecido, acompanhado de duas testemunhas, deve comparecer ao Cartório do Registro Civil, solicitando o preenchimento das três vias da declaração de óbito (art. 77 da Lei 6.015/73). Após o registro, o cartório reterá a 2a via e encaminhará as duas restantes para a Secretaria Municipal de Saúde. 


\section{LOCAIS DE EXAMES PERICIAIS}

\subsection{Definição}

Local de exame pericial é todo aquele que, por ter sido palco de acontecimento ou abrigar objeto de interesse à Justiça Civil ou Criminal, deve ser examinado pelo perito e, eventualmente, pelos assistentes técnicos.

Dividem-se em locais de interesse à Justiça Criminal e locais de interesse à Justiça Cível. Estes últimos, pela variedade e complexidade das causas, a maioria das quais fora da proposta deste trabalho, não serão aqui analisados, muito embora a eles possam ser aplicados os princípios gerais descritos para os locais de interesse à Justiça Criminal.

\subsection{Locais de interesse à Justiça Criminal}

Normalmente, ao mencionar os locais de interesse à Justiça Criminal, utiliza-se a expressão "local de crime", embora nem todo exame realizado confirme a ocorrência de um fato típico, podendo revelar uma ocorrência natural, acidental ou casual, sem qualquer conotação penal.

Eraldo Rabelo explica que, apesar de parecer imprópria, a denominação local de crime tem por objetivo "manter perenemente viva a advertência no sentido de que toda ocorrência suspeita de se constituir em infração penal deve ser investigada como crime até prova em contrário". Conclui que a praxe é salutar, "pois jamais o investigador criminal consciente da sua responsabilidade deverá esquecer que um dos recursos mais freqüentemente empregados pelo criminoso astuto, para escapar à punição, é o de dar ao perpetrado ilícito penal a aparência de fato natural ou acidental ${ }^{77,}$.

Em que pese a posição do renomado autor, preferimos a expressão "local do fato", que poderá ser local de crime, uma vez determinada a ocorrência de delito, ou local de irrelevante penal.

Em um ponto, porém, assiste razão ao respeitado mestre. Para o perito que atende à ocorrência, pouco importa inicialmente a natureza do fato. Deve realizar seu exame sempre tendo em mente a possibilidade, ainda que remota, da ocorrência de ilícito penal,

\footnotetext{
${ }^{77}$ RABELO, Eraldo. Curso de criminalística. Porto Alegre: Sagra Luzzatto, 1996. p. 44.
} 
até porque, no mais das vezes, será o seu trabalho que irá determinar a natureza jurídica do evento.

Mesmo os fatos que não constituem crimes, como morte natural, acidental ou suicídio, darão origem a inquérito policial que somente será arquivado quando afastada completamente a possibilidade de ilícito. Além disso, é possível que um fato penalmente atípico possa gerar responsabilidade civil e que o laudo seja utilizado como prova do evento e de suas conseqüências.

Local do fato, assim, é toda área em que tenha ocorrido um fato juridicamente relevante e que, podendo vir a ser definido como penalmente típico, exige providências por parte da polícia judiciária ${ }^{78}$.

\subsection{Classificação dos locais de interesse à Justiça Criminal}

Os locais podem ser classificados segundo vários critérios. O quadro a seguir resume os principais:

Local do fato $\left\{\begin{array}{l}\text { Quanto ao lugar em que o fato é cometido }\left\{\begin{array}{l}\text { interno } \begin{array}{l}\text { externo } \\ \text { relacionado }\end{array} \\ \text { Quanto ao afluxo de populares }\left\{\begin{array}{l}\text { público ou aberto } \\ \text { em veículo } \\ \text { privado ou fechado }\end{array}\right. \\ \text { Quanto à distribuição dos indícios e vestígios }\end{array}\left\{\begin{array}{l}\text { contínuos } \\ \text { descontínuos }\end{array}\right.\right. \\ \text { Quanto à preservação }\left\{\begin{array}{l}\text { idoo âmbito da perícia }\left\{\begin{array}{l}\text { idôneo ou preservado } \\ \text { mediatos } \\ \text { distantes }\end{array}\right. \\ \text { inidôneo ou violado } \\ \text { prejudicado }\end{array}\right.\end{array}\right.$

\footnotetext{
${ }^{78}$ Carlos Kehdy, define local de crime como "toda área onde tenha ocorrido um fato que assuma a configuração de delito e que, portanto, exija as providências da polícia" (Manual de locais de crime Coletânea Acácio Nogueira. 3 ed. São Paulo: Escola de Polícia de São Paulo, 1963).
} 


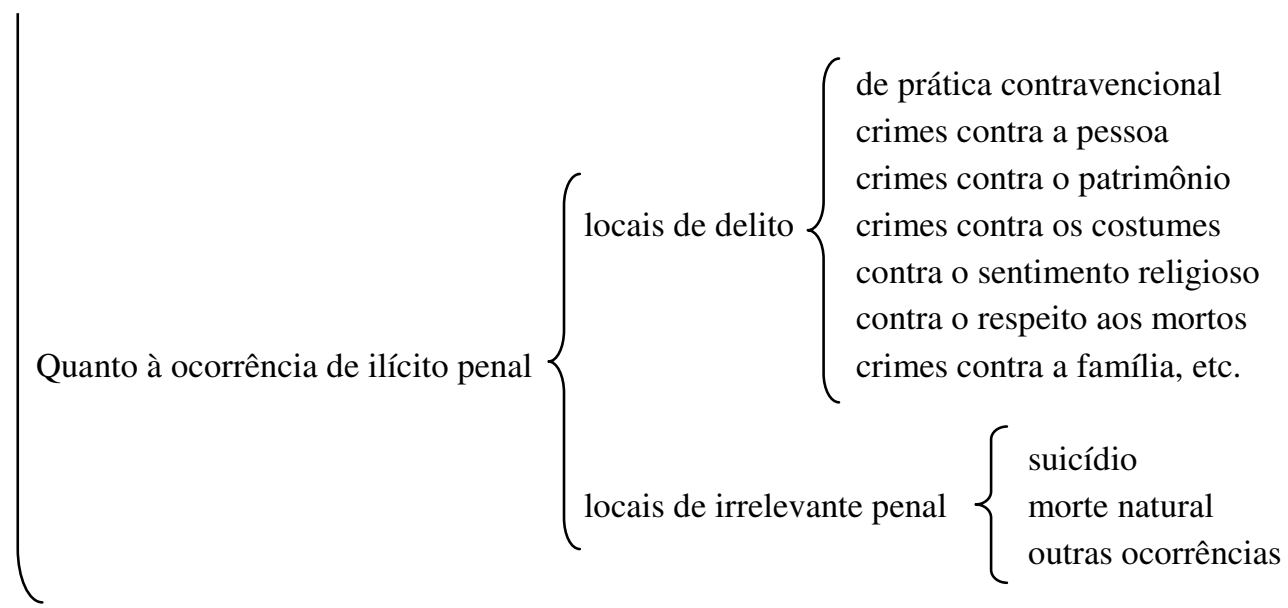

Internos são os locais situados em qualquer ambiente fechado, como, por exemplo, o interior de habitações (ocupadas ou não), estabelecimentos comerciais, galpões industriais, estacionamentos fechados, barracas, containers, etc.

Externos são os sítios a céu aberto, em que os indícios e vestígios podem desaparecer com maior facilidade por exposição às intempéries, como terrenos baldios, quintais, pátios de estacionamento, praças, vias públicas e outros. Esses locais reclamam uma maior atenção da autoridade policial, em relação à preservação, e do perito no sentido de realizar o exame o mais rápido possível.

Não se deve confundir local externo com local público ou aberto. Os locais externos podem ser públicos ou privados, conforme permitam ou não a livre afluência de populares. Da mesma forma, os locais internos podem ou não ser privados ${ }^{79}$.

Relacionadas são as áreas que, embora fisicamente afastadas do local do fato, apresentam vestígios e indícios que guardam relação de interesse com o evento ocorrido. Seja o exemplo de uma carta suicida deixada no local de trabalho, tendo o ato extremo ocorrido na residência da vítima; a arma utilizada em um homicídio, abandonada pelo autor a quilômetros do local; partes do corpo da vítima deixadas em um terreno distante do lugar em que ocorreu o crime, etc.

Quanto ao âmbito da perícia, os locais podem ser imediatos, mediatos e distantes. O local imediato corresponde ao lugar onde ocorreu o fato, pedindo um exame muito minucioso e cuidadoso. O local mediato compreende as cercanias ou, nas palavras de

\footnotetext{
${ }^{79}$ Pela classificação proposta por Carlos Kehdy, os fatos ocorridos em terrenos murados ou cercados também devem ser considerados como internos (KEHDY, Carlos. Manual de locais de crime. 3 ed. São Paulo: Escola de Polícia de São Paulo, 1963. p. 13. (Coletânea Acácio Nogueira.)
} 
Carlos Kehdy, "a área intermediária entre o local onde ocorreu o fato (local propriamente dito) e o grande ambiente exterior ${ }^{80 "}$. O local distante é aquele relacionado, que embora separado fisicamente do local do fato, com ele guarda relação probatória.

No que toca à preservação, os locais podem ser idôneos (ou preservados), inidôneos (ou violados) e prejudicados. A importantíssima questão da preservação dos locais será analisada no tópico seguinte.

Por derradeiro, em relação à ocorrência ou não de ilícitos penais, os locais dividem-se em locais de delitos (crimes ou contravenções) e locais de irrelevantes penais (suicídios comprovados, mortes naturais e acidentes sem repercussão criminal). O perito deve ter sempre em mente que boa parcela das ocorrências policiais somente terá sua etiologia jurídica desvendada após a perícia. Além disso, mesmo nos casos em que não há interesse da Justiça Criminal, é possível que exista alguma repercussão na esfera cível, daí a necessidade de buscar a excelência em todos os exames, por mais simples e irrelevantes que pareçam.

\subsection{A preservação dos locais de crime}

$\mathrm{O}$ art. $6^{\circ}$ do Código de Processo Penal indica as medidas que devem ser tomadas pela autoridade policial tão logo tome conhecimento da prática de uma infração penal. Entre as medidas preconizadas, a primeira tarefa é a de "dirigir-se ao local, providenciando para que não se alterem o estado e conservação das coisas, até a chegada dos peritos criminais" e, em segundo lugar, "apreender os objetos que tiverem relação com o fato, após liberados pelos peritos criminais." (grifo nosso)

As demais recomendações do dispositivo, salvo a determinação para que requisite o exame de corpo de delito e outras perícias (item VII), dizem respeito à produção da prova, mas não se relacionam diretamente com a prova pericial, e sim com a atividade de investigação afeta ao delegado de polícia.

CPP

Art. $6^{\circ}$. Logo que tiver conhecimento da prática da infração penal, a autoridade policial deverá:

${ }^{80}$ KEHDY, Carlos. op. cit., p. 14. 
I - dirigir-se ao local, providenciando para que não se alterem o estado e conservação das coisas, até a chegada dos peritos criminais;

II - apreender os objetos que tiverem relação com o fato, após liberados pelos peritos criminais;

III - colher todas as provas que servirem para o esclarecimento do fato e suas circunstâncias;

IV - ouvir o ofendido;

V - ouvir o indiciado, com observância, no que for aplicável, do disposto no Capítulo III do Título VII, deste Livro, devendo o respectivo termo ser assinado por 2 (duas) testemunhas que lhe tenham ouvido a leitura;

VI - proceder a reconhecimento de pessoas e coisas e a acareações;

VII - determinar, se for caso, que se proceda a exame de corpo de delito e a quaisquer outras perícias;

VIII - ordenar a identificação do indiciado pelo processo datiloscópico, se possível, e fazer juntar aos autos sua folha de antecedentes;

IX - averiguar a vida pregressa do indiciado, sob o ponto de vista individual, familiar e social, sua condição econômica, sua atitude e estado de ânimo antes e depois do crime e durante ele, e quaisquer outros elementos que contribuírem para a apreciação do seu temperamento e caráter.

Reforçando a determinação inicial, o Código de Processo Penal lembra novamente, no art. 169, caput, o dever da autoridade policial de preservar o local até a chegada dos peritos e a estes a necessidade de registrar no laudo as alterações encontradas e suas conseqüências (art. 169, parágrafo único):

\section{CPP}

Art. 169. Para o efeito de exame do local onde houver sido praticada a infração, a autoridade providenciará imediatamente para que não se altere o estado das coisas até a chegada dos peritos, que poderão instruir seus laudos com fotografias, desenhos ou esquemas elucidativos.

Parágrafo único. Os peritos registrarão, no laudo, as alterações do estado das coisas e discutirão, no relatório, as consequiências dessas alterações na dinâmica dos fatos.

\subsection{Indícios, vestígios, circunstâncias e presunções}

Ensina Frederico Marques $^{81}$, que a prova por indícios, presunções e circunstâncias é muito mal definida, consistindo em um mero "recolher e interpretar todos

\footnotetext{
${ }^{81}$ MARQUES, José Frederico. Elementos de direito processual penal, cit., p. 450.
} 
os fatos ou circunstâncias que possam levar à descoberta da verdade”. Além disso, não há uma denominação bem precisa sobre a prova, "os civilistas preferem falar de presunções enquanto que os criminalistas usam da expressão indícios e os juristas anglo-americanos de circunstâncias".

Realmente, o Código de Processo Civil não cuida do tema, utilizando o vocábulo “vestígio" uma única vez, ao tratar da demarcação (art. 961, II, do CPC).

O Código de Processo Penal é mais pródigo. Utiliza o termo "vestígio" em diversos dispositivos (arts. 158, 164, 167, 171, 525, 535, $\S 1^{\circ}$ e 564, III, b) e indício em outros tantos (arts. 126, 134, 290, §1º $, b, 312$, 408 e 409), mas define apenas o último como toda circunstância conhecida e provada, que, tendo relação com o fato, autoriza, por indução, concluir sobre a existência de outras circunstâncias (art. 239 do CPP):

\section{CPP}

Art. 239. Considera-se indício a circunstância conhecida e provada, que, tendo relação com o fato, autorize, por indução, concluir-se a existência de outra ou outras circunstâncias.

Necessário, assim, fazer uma diferenciação entre os termos vestígio, indício, circunstância e presunção.

Vestígio é qualquer marca, traço, sinal, rastro, mancha ou outra evidência material considerada de modo impreciso. É, em resumo, tudo que pode ser encontrado no local do fato e que pode ou não ter relação com a natureza jurídica do evento ou vir a ser utilizado como meio de prova.

Indício, por outro lado, como ensina Helio Tornaghi:

"É sempre um fato: o fato de estar com a faca, o fato de guardar coisa do morto, etc. E o fato (por exemplo, o de ter as jóias do assassinado) indica, aponta, assinala alguma coisa a respeito do crime (a autoria, a maneira pela qual foi praticado), por estar ligado a ele, por estar em torno dele; e como o que está em torno de alguma coisa (circum stare) se chama circunstância, pode acrescentar-se que o indício não apenas é um fato, mas também é um fato ligado ao crime, de tal modo conexo com ele que permite concluir-se algo a respeito dele, como no exemplo acima, em que é possível inferir que provavelmente o homem encontrado com a faca e as jóias é o autor do crime, que a morte foi produzida por ferimentos e que o móvel do crime foi o roubo." 82

\footnotetext{
${ }^{82}$ TORNAGHI, Hélio. op. cit., p.451.
} 
Deve-se acrescentar que a palavra fato, em matéria processual, notadamente no campo probatório, admite um conceito bastante amplo, que engloba diversos acontecimentos do mundo exterior, alcançando coisas, lugares, pessoas e documentos ${ }^{83}$. Por essa razão, os indícios, ao contrário dos vestígios, podem ser materiais ou não. Alguns traços comportamentais e de personalidade, por exemplo, indicam a presença de algum transtorno mental, mas não se materializam no mundo real.

Circunstâncias são condições de tempo, lugar ou modo, que cercam ou acompanham determinado fato ou situação e que lhes é peculiar. São exemplos as circunstâncias de caráter pessoal, tão importantes em Direito Penal, como idade, profissão, higidez mental, relações de parentesco e outras.

Finalmente, presunções são os julgamentos. As opiniões pessoais, convicções ou suspeitas sobre a natureza de determinada ocorrência, baseadas nos indícios, vestígios e circunstâncias observados. Estes são os fatos indicativos e a presunção o fato indicado. $\mathrm{O}$ encontro de uma garrafa de aguardente vazia, o andar cambaleante, o odor alcoólico, a incoordenação motora são indícios de embriaguez. São os fatos indicativos, enquanto o diagnóstico de embriaguez é a presunção ${ }^{84}$.

Desses conceitos resultam algumas conclusões ${ }^{85}$ :

a) os indícios, vestígios e circunstâncias constituem manifestação ou conseqüência do fato que se pretende provar, mas não o fato em si;

b) a relação entre os vestígios, indícios ou circunstâncias e o fato pode ser conseqüencial (decorrem do fato, como a hemorragia flui do ferimento) ou de identidade (constituem atributos do fato, como o chumbo é elemento constitutivo dos projéteis);

c) a presunção é construída intelectualmente a partir dos vestígios, indícios e circunstâncias;

d) a presunção pode ser categórica, constituindo prova indiciária, ou de probabilidade, não servindo como meio de prova, mas útil na orientação das investigações.

\footnotetext{
${ }^{83}$ Apud TOURINHO FILHO, Fernando da Costa. op. cit., p. 204.

${ }^{84}$ Além das presunções normais, humanas ou comuns, existem as presunções jurídicas, que podem ser absolutas ou juris et de jure, não admitindo prova em contrário, mesmo que existente, e relativas ou juris tantum, que permitem prova contrária ao fato alegado.

${ }^{85}$ Baseadas em conclusões similares propostas por RABELO, Eraldo. op. cit., p. 36.
} 
Os peritos criminais e os médicos-legistas trabalham basicamente sobre vestígios e indícios materiais (também chamados provas objetivas), podendo eventualmente inteirarse dos indícios subjetivos e das circunstâncias para poder formar suas presunções.

\subsection{Classificação dos indícios materiais e vestígios}

Os vestígios e indícios materiais podem ser organizados segundo vários critérios e o quadro a seguir resume algumas das principais classificações existentes, com algumas modificações.

Trata-se de divisão meramente exemplificativa e com finalidade didática, já que seria praticamente impossível, devido à variedade, indicar todos os vestígios e indícios de possível interesse no local do fato.

$$
\begin{aligned}
& \text { Quanto ao modo de produção }\left\{\begin{array}{l}
\text { propositais } \\
\text { acidentais }
\end{array}\right. \\
& \text { Quanto à percepção }\left\{\begin{array}{l}
\text { visíveis } \\
\text { latentes }
\end{array}\right. \\
& \text { Quanto à durabilidade }\left\{\begin{array}{l}
\text { perenes } \\
\text { persistentes } \\
\text { fugazes }
\end{array}\right.
\end{aligned}
$$




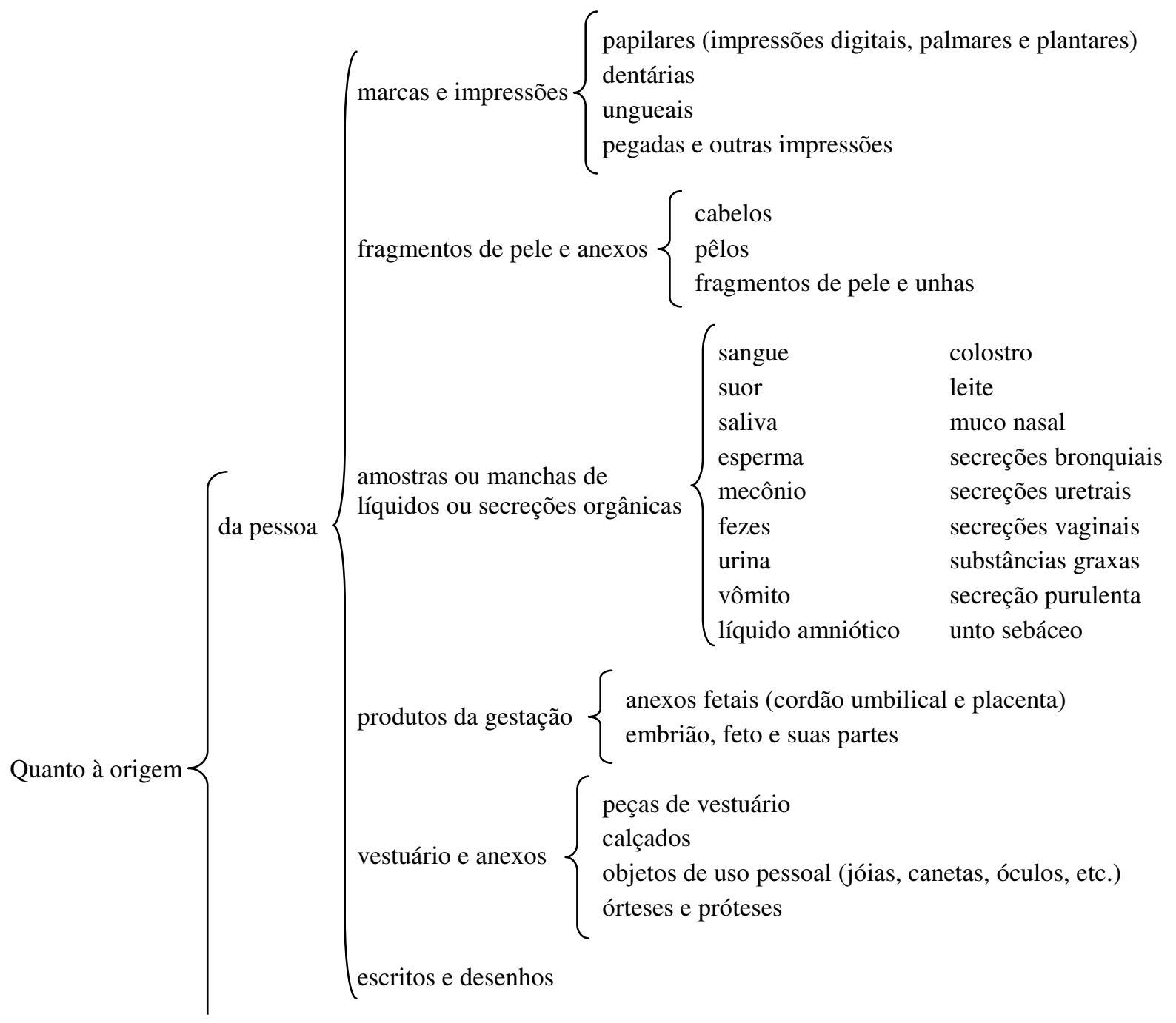




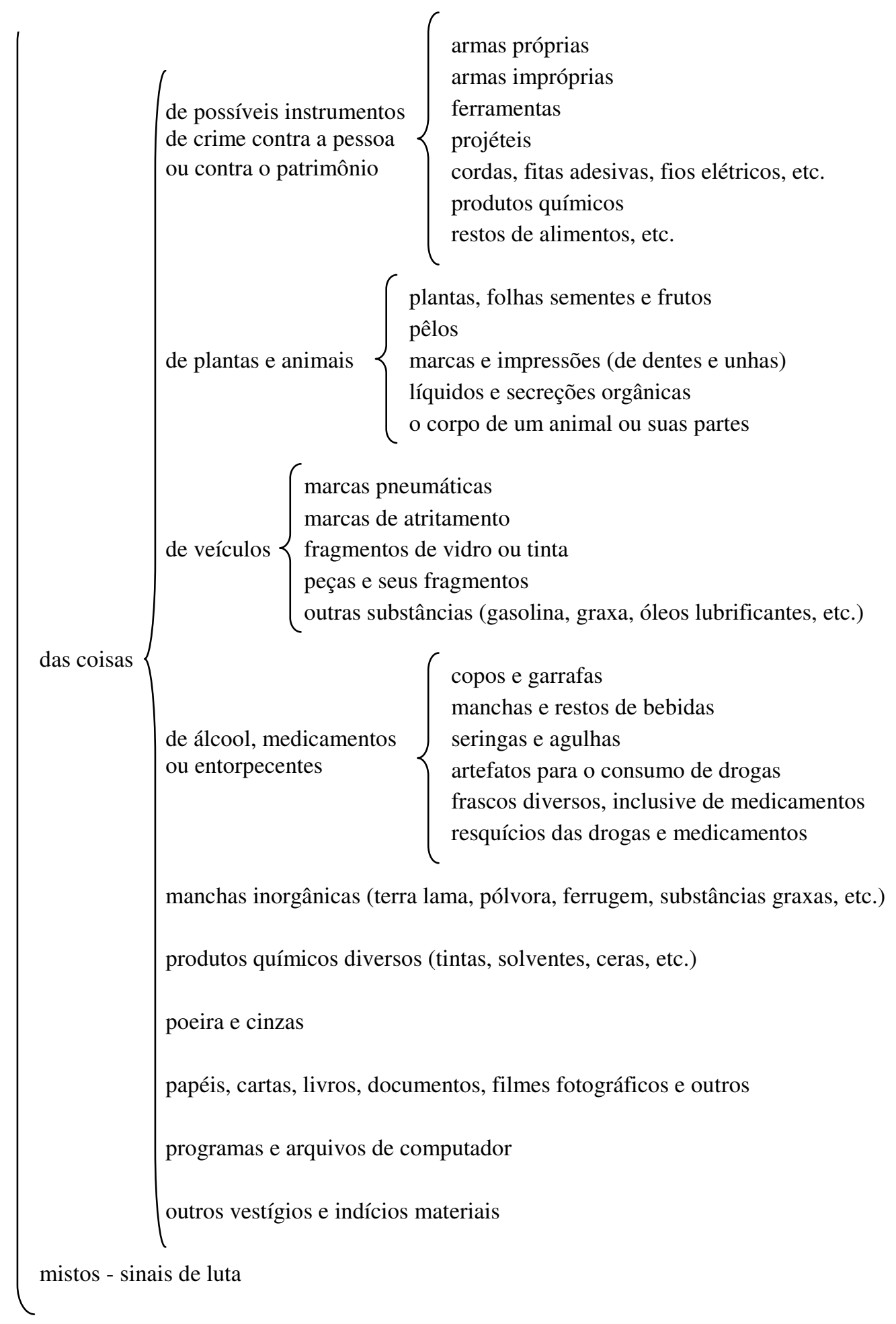

\subsubsection{Propositais e acidentais}

Vestígios e indícios materiais propositais são os deliberadamente deixados no local por alguma finalidade. Como exemplos, temos a conhecida figura de um crânio 
humano com duas tíbias cruzadas como sinal de perigo, sempre colocado com a intenção de prevenir os incautos; a marca dos fabricantes para prevenir contrafações; as placas e sinais de trânsito; os carimbos identificadores de repartições públicas, etc.

Eraldo Rabelo $^{86}$ lembra que a finalidade precípua de um vestígio ou indício proposital não é a de provar um fato, mas apenas a de indicar determinada qualidade ou condição, de maneira a torná-las conhecidas de plano, por intermédio da identificação imediata do símbolo característico.

Os indícios e vestígios propositais somente têm interesse quando se destinam a comprovar a autenticidade de alguma coisa em eventual confronto com similares ou quando configuram uma simulação.

$\mathrm{Na}$ simulação, o autor de um fato definido como crime pode tentar destruir eventuais evidências existentes (mais comum) ou deixar, no local, provas falsas, com uma carta forjada de suicídio, ou as impressões da vítima na arma do crime, visando confundir as investigações.

Quando o agente tenta remover os vestígios, acaba produzindo outros, que podem ser apreciados pelo perito. No caso de provas falsas plantadas, um exame aguçado certamente irá demonstrar a sua inconsistência.

Vestígios e indícios materiais acidentais são aqueles produzidos involuntariamente pelo agente. São exemplos as impressões digitais, as manchas de material orgânico, pêlos, cinzas, fibras, sinais de luta, danos involuntários, a posição do corpo, os projéteis de arma de fogo, etc.

O verdadeiro trabalho pericial de campo repousa exatamente na observação, coleta, preservação e análise desses sinais involuntários. Essa é a prova pericial em essência e o bom perito é aquele que calma, minuciosa e cuidadosamente sabe recolher essas provas.

\subsubsection{Perceptíveis e latentes}

Perceptíveis são os vestígios e indícios materiais que podem ser diretamente captados pelos sentidos humanos (visão, audição, paladar, olfato e tato), sem o auxílio de

${ }^{86}$ RABELO, Eraldo. op. cit., p. 37. 
qualquer artifício ou aparelho, como manchas de sangue, danos materiais evidentes, armas eventualmente deixadas no local ou sinais de arrastamento.

Outros, ditos latentes, reclamam a utilização de técnicas ou aparelhos especiais para poderem ser observados e aproveitados. Nesta categoria temos as manchas de esperma, os microrresíduos deixados pelo disparo de armas de fogo (residuografia), algumas impressões digitais, etc.

\subsubsection{Perenes, persistentes e fugazes}

Perenes são os vestígios e indícios materiais que não desaparecem com o tempo ${ }^{87}$, somente sendo destruídos por evento natural incomum e de grandes proporções, ou propositalmente, pela ação do homem. São perenes, por exemplo, as ossadas, os danos decorrentes de acidentes automobilísticos, as cavidades produzidas por projéteis de arma de fogo em móveis ou objetos, os próprios projéteis e outros.

Persistentes são aqueles que não reclamam a ação imediata do perito na sua recolha, porque permanecerão indeléveis por um período mais ou menos longo, permitindo sua apreciação tardia. São exemplos as manchas de sangue em tecidos, os pêlos, as fibras e outros materiais.

Fugazes são os que desaparecem com certa facilidade, reclamando uma atuação rápida na sua recolha e apreciação. Como exemplos, podemos citar as marcas de pneus e pegadas, as manchas de sangue em locais públicos, os resíduos decorrentes do disparo de armas de fogo, substâncias voláteis, etc.

\subsubsection{Marcas e impressões produzidas pela pessoa}

Embora os termos sejam utilizados como sinônimos, as marcas referem-se mais aos vestígios tridimensionais deixados sobre uma superfície, enquanto as impressões são desenhos planos produzidos por substâncias orgânicas ou não. Dentre as marcas e impressões que podem ser deixadas pelo ser humano nos locais de crime destacam-se:

\footnotetext{
${ }^{87} \mathrm{Ou}$ que pelo menos persistem por considerável intervalo de tempo.
} 
- impressões papilares;

- impressões de luvas;

- marcas ungueais;

- marcas produzidas pelos dentes e lábios;

- marcas e impressões produzidas pelos pés descalços ou por solados (pegadas);

- marcas e impressões de partes do corpo;

- marcas de arrastamento; e

- marcas deixadas por peças de vestuário;

- outras marcas e sinais.

\subsubsection{Impressões papilares}

As impressões papilares (palmares, plantares e digitais) são, sem dúvida, as mais importantes marcas deixadas pela pessoa no local do fato, primeiro por serem freqüentes e em segundo lugar pela facilidade de recolha e classificação, permitindo a comparação e identificação segura de seu autor. O estudo das impressões papilares é capítulo especial da antropologia forense e foge ao escopo deste trabalho.

\subsubsection{Impressões de luvas}

O conhecimento generalizado sobre a importância das impressões papilares no reconhecimento faz com que os criminosos, com certa freqüência, utilizem luvas de couro ou borracha (luvas cirúrgicas) na tentativa de iludir as investigações.

Dessa forma, o encontro de impressões de luvas (glove smears), em geral, significa que o autor procurou evitar deixar suas próprias impressões no local do fato e isso, de per si, já é um forte indício sobre a natureza delituosa da ação.

Elas são encontradas quando da procura por impressões papilares e normalmente fazem com que o pesquisador acabe, erroneamente, desistindo da busca. 
Ainda que sejam encontradas marcas de luvas, a pesquisa por impressões papilares deve continuar, mas com especial atenção aos locais onde o agente pode necessitar trabalhar com as mãos nuas ou usar muita força com a ponta dos dedos, como, por exemplo, para abrir pequenos cadeados ou desatarraxar porcas e parafusos.

É possível, também, que as luvas se dobrem ou levantem, descobrindo o punho ou parte da palma da mão, o que fará com que o agente, descuidado, possa deixar algumas impressões papilares de valia.

Mesmo que isso não ocorra, especialmente com relação às luvas de couro mais velhas, é possível identificar uma espécie de padrão e alguns desgastes que, caso a peça seja apreendida, poderão servir para comparação e identificação.

Fisher $^{88}$ lembra que o couro da luva normalmente apresenta uma superfície muito característica que mostra sulcos dispostos em uma conformação mais ou menos definitiva. Nas luvas feitas à mão, o padrão da superfície varia de acordo com o método de fabricação, os fios e o material utilizado. Essas texturas ou pregas poderão tornar possível a identificação. Por outro lado, as luvas industrializadas são padronizadas e, por isso, a identificação não pode basear-se apenas na textura do material.

Depois de algum tempo de uso, tanto as luvas feitas à mão quanto as industrializadas acabam por adquirir certas deformações, especialmente nas regiões onde a peça não se encaixa perfeitamente à anatomia da mão, bem como alguns danos decorrentes da abrasão sobre superfícies diversas. Essas dobras e danificações, quando encontradas, irão fornecer um valioso sinal para identificação positiva, no caso de apreensão da peça com o autor do fato.

As impressões de luvas são encontradas sobre superfícies lisas e polidas e o seu levantamento requer muito mais atenção e cuidado, uma vez que são mais frágeis e menos evidentes que as impressões papilares.

Além de luvas, os criminosos costumam utilizar outros materiais para proteger as mãos, como lenços, panos, toalhas, meias, etc. As impressões deixadas por esses revestimentos normalmente não têm nenhum interesse criminalístico. Entretanto, se encontrada alguma marca ou sinal com elementos de identificação, ainda que a futura comparação seja improvável, o vestígio deve ser preservado e levantado.

\footnotetext{
${ }^{88}$ FISHER, Barry A. J. Techniques of crime scene investigation. $5^{\text {th }}$ ed. Boca Raton, Florida: CRC Press LLC,
} 1993. p. 118. 


\subsubsection{Marcas ungueais}

As marcas ungueais (de unhas) são encontradas com mais freqüência no corpo humano, quer na vítima, em decorrência da agressão sofrida, como nos casos de estrangulamento ou em crimes de cunho sexual, quer no próprio agressor, produzidas pelas manobras de defesa empregadas pelo ofendido.

Nada impede, porém, que sejam eventualmente deixadas em outros suportes plásticos (capazes de serem moldados ou modelados), como parafina, borracha ou couro.

As unhas são instrumentos cortocontundentes, que agem por pressão sobre uma linha, e produzem lesões cortocontusas.

O levantamento é sempre fotográfico e o exame é realizado por comparação, levando-se em consideração principalmente o tamanho, a curvatura e eventuais anomalias.

Além das marcas ungueais, é possível encontrar fragmentos de unhas ou unhas inteiras nos locais.

\subsubsection{Marcas produzidas pelos dentes e lábios}

Os dentes podem produzir marcas por compressão ou escoriação, tanto sobre o corpo humano (vítima ou autor) como em alguns alimentos.

São achados comuns em crimes sexuais. $\mathrm{Na}$ vítima, distribuem-se preferencialmente sobre os seios, braços, nádegas, coxas e genitais. Podem ser encontradas, ainda, no corpo do autor, como decorrência de ferimentos recebidos por manobras de defesa do ofendido. Nessas circunstâncias, são mais comuns sobre os braços, mãos e pernas.

Eventualmente, podem ser descobertos, no local, dentes inteiros ou partes da coroa dentária, perdidos em razão de agressão. Esses dentes ou fragmentos devem ser sempre recolhidos para posterior confronto.

Nos alimentos sólidos como queijos, barras de chocolate, manteiga, frutas e determinados doces de consistência mais firme, também é possível encontrar marcas dentárias (mordidas). 
Os dentes são instrumentos contundentes, que agem por pressão sobre uma superfície e, dependendo da parte da arcada dentária envolvida, podem produzir lesões contusas ou cortocontusas.

Essas marcas correspondem, geralmente, a uma parte da arcada ou a dentes isolados. O levantamento é feito por fotografia e, sempre que possível, pela modelagem. Dependendo do suporte, o perito deve providenciar a preservação e o recolhimento da amostra com a maior celeridade possível. No caso de alimentos, por exemplo, o calor (desidratação) ou a putrefação podem colocar a perder elementos importantíssimos de identificação.

No corpo humano, após a fotografação com escala, pode-se tentar a modelagem com silicone ou outros materiais indicados para moldes dentários. A qualidade do molde, entretanto, irá depender da profundidade da mordida.

Os confrontos devem ficar sempre a cargo de odontólogo-legal habilitado.

Além das marcas de dentes, podem ser encontradas impressões labiais, normalmente deixadas em batom. Embora o confronto dessas impressões seja muito difícil, é possível que a presença de alguma cicatriz ou outra particularidade permita o confronto. Assim, ainda que freqüentemente inúteis sob o ponto de vista criminalístico, devem ser levantadas e preservadas.

Svensson \& Wendel $^{89}$ lembram que, ainda que a identificação pelas marcas de batom seja rara, a coloração e espessura são circunstâncias importantes, assim como a natureza do pigmento que pode ser quimicamente determinada, embora seja necessária uma quantidade razoável do cosmético. Além disso, a marca de batom em uma ponta de cigarro pode ser um vestígio importante e não deve ser desconsiderado.

\subsubsection{Marcas e impressões produzidas pelos pés descalços ou por solados (pegadas)}

Pegada (foot print) é toda marca (depressão) ou impressão produzida no solo ou em outros suportes (portas, janelas, móveis, etc.) pelo pé calçado ou descalço.

\footnotetext{
${ }^{89}$ SVENSSON, Arne; WENDEL, Otto. Techniques of crime scene investigation. $2^{\text {nd }}$ ed. New York: American Elsevier Publishing Company Inc., 1971. p. 156 e 168.
} 
Com relação aos pés descalços, não se deve confundir a pegada com a impressão plantar, forma muito particular de impressão em que podem ser identificadas as cristas e sulcos papilares, formadores do desenho papilar, e que pode permitir uma identificação segura de seu autor. O estudo das impressões plantares é capítulo da antropologia forense e foge ao escopo deste trabalho.

As marcas e impressões produzidas pelos pés descalços ou por solados, ainda que elementos de extrema valia na investigação, referem-se mais à forma externa dos pés ou dos calçados e permitem presunções importantes sobre o autor, como estatura, eventuais defeitos físicos, maneirismos no andar e outras ${ }^{90}$.

Não se pode esperar uma reprodução perfeita do salto e da sola dos calçados. Svensson \& Wendel $^{91}$ lembram que, como regra, o resultado da modelagem é bem diferente do solado original. O modelo tem uma forma arqueada em que a base do salto e a ponta da sola são consideravelmente mais profundas que as partes intermediárias. Isso resulta do fato de, em uma caminhada normal, a base do salto ser pressionada contra o piso primeiro. Depois que todo o pé está apoiado, a outra perna é levantada e o corpo inclina-se para frente, fazendo com que a ponta do calçado seja fortemente premida contra o solo (figura 1).

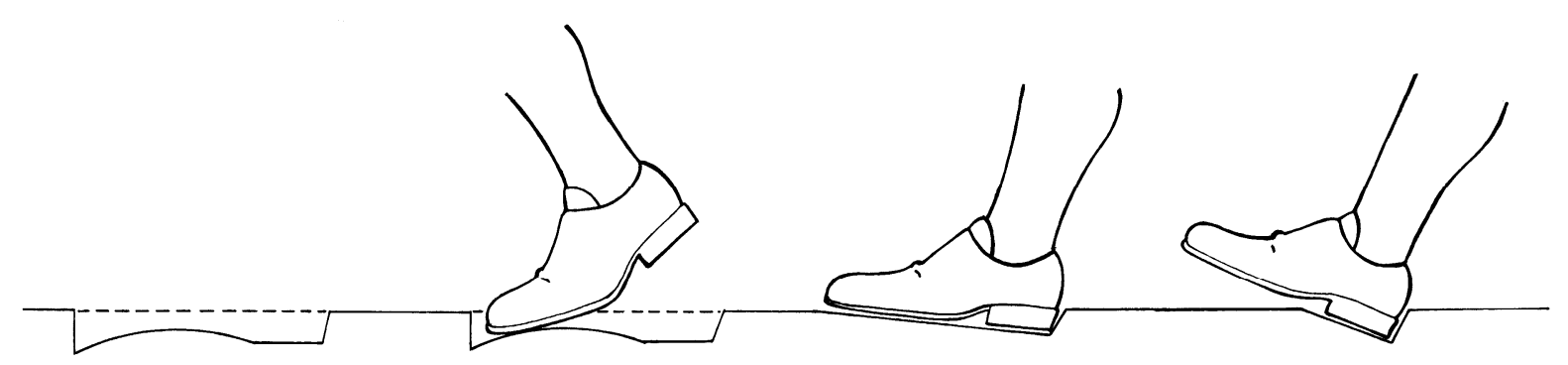

Figura 1 - Mecanismo de produção das pegadas.

Além disso, existem alguns maneirismos no andar que variam de pessoa para pessoa e que alteram sensivelmente as impressões e marcas. $\mathrm{O}$ andar elegante para as mulheres, por exemplo, reclama que a ponta do pé seja colocada à frente e apenas depois o calcanhar.

\footnotetext{
${ }^{90} \mathrm{Na}$ introdução deste trabalho descrevemos sucintamente as provas existentes no caso O. J. Simpson, entre as quais pegadas, em sangue, deixadas ao lado do corpo das vítimas.

${ }^{91}$ SVENSSON, Arne; WENDEL, Otto. op. cit., p. 72.
} 
O tipo e a inclinação do terreno também interferem. Nos locais planos as pegadas tendem a reproduzir, mais ou menos, o tamanho do pé, enquanto nas subidas, os artelhos se contraem, fazendo com que fiquem um pouco menores ${ }^{92}$.

O desenho indica as principais regiões dos pés e dos calçados para efeito de orientação:
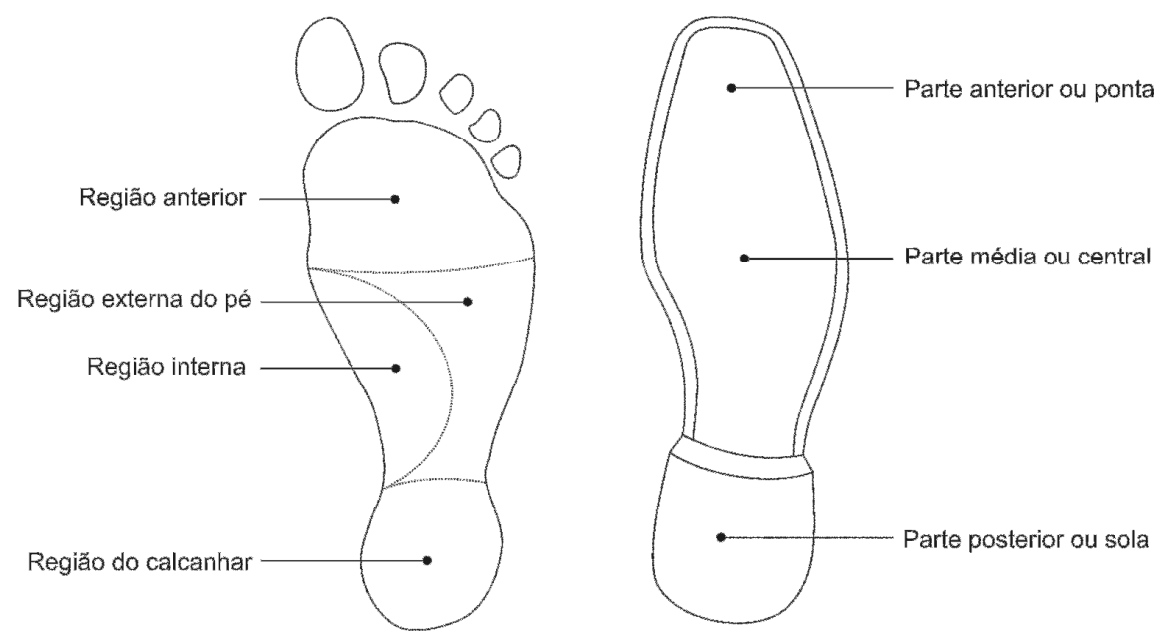

Figura 2 - Regiões dos pés e dos calçados.

Apesar dessas considerações, as pegadas, quando detalhadas, fornecem um importante elemento de identificação, principalmente se a pessoa que produziu as marcas ou impressões nega sua presença no local do fato.

As regras que devem ser observadas para o estudo das marcas e impressões são ${ }^{93}$ :

a) reproduzir a pegada por meio de desenho, fotografia ou modelagem, indicando suas medidas principais. No caso do desenho ou da fotografia, a escala nunca deve ser colocada sobre o desenho, e, tratando-se de figura bidimensional, o ideal é utilizar duas escalas perfeitamente alinhadas (vide figura 3);

\footnotetext{
${ }^{92}$ KEHDY, Carlos. op. cit., p. 157.

${ }^{93}$ Apud MONTIEL SOSA, Juventino. Criminalística. TT I, II e III. México: Limusa, 2000. p. 70.
} 

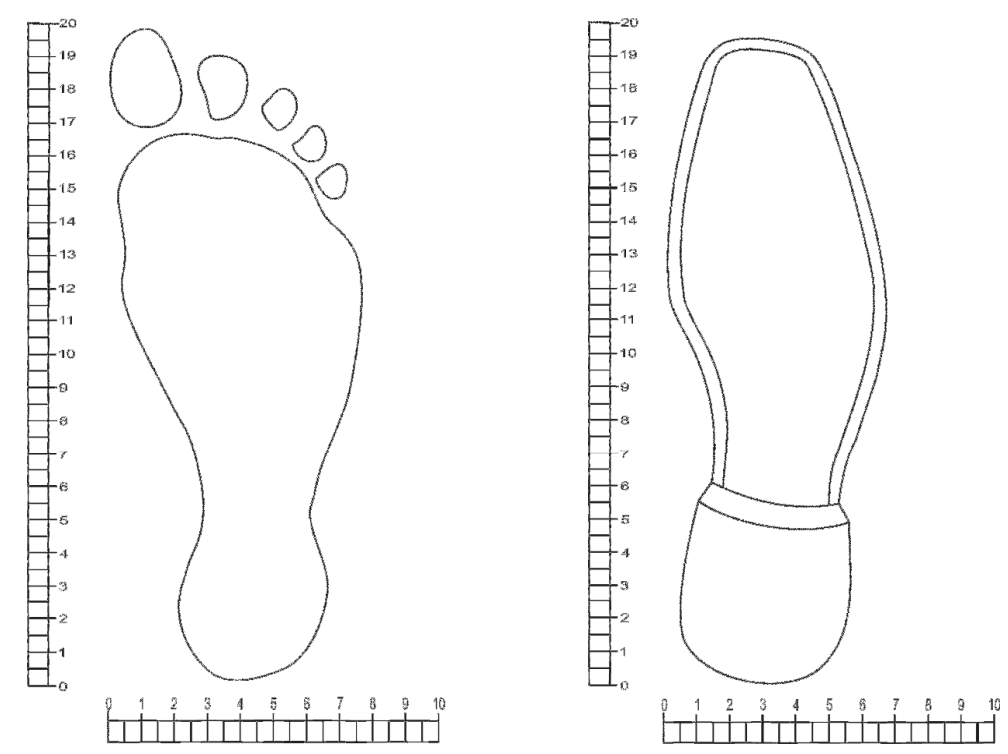

Figura 3 - Modo de colocação das escalas.

b) utilizar as mesmas técnicas para colher a pegada testemunha do suspeito;

c) efetuar o estudo comparativo das pegadas colhidas do local do fato com aquelas obtidas da pessoa suspeita;

d) nunca se devem comparar as características do molde, desenho ou fotografia diretamente com o solado ou com o pé que se supõe tenha produzido a marca ou impressão. Moldes devem ser comparados com moldes, fotografias com fotografias e assim por diante;

e) todos os moldes, desenhos e fotografias, tanto os colhidos no local como os tomados do suspeito, devem ser preservados adequadamente como meios de prova.

\subsubsection{Marcas e impressões de partes do corpo}

Embora raras, podem ser encontradas impressões ou marcas de partes do corpo em suportes como tinta fresca, cimento, areia ou lama. Sempre que possível, tais marcas devem ser preservadas pela fotografia, desenho ou modelagem. A impressão de um ombro na parede, por exemplo, pode dar uma boa idéia da altura da pessoa que a produziu. 
Em alguns casos extremos, as marcas podem exibir detalhes de identificação. Svensson \& Wendel $^{94}$ relatam o caso de um ladrão que caiu de frente em uma poça de lama, deixando a marca de seu rosto, com a impressão do nariz característico, e de ambas as mãos, uma delas segurando um pé-de-cabra e a outra uma pistola.

No caso específico de marcas de dedos ou mãos, é necessário verificar se os desenhos papilares estão presentes. Mesmo nos casos em que não existem figuras papilares, as marcas e impressões devem ser levantadas, pois podem servir como prova de orientação em determinados casos.

\subsubsection{Marcas de arrastamento}

Ainda que não sirvam para identificação, as marcas de arrastamento são importantíssimas para a perícia porque demonstram claramente a intenção do agente em encobrir o crime ou, ao menos, inovar a posição de coisas ou pessoas com o fito de induzir em erro a Justiça.

Nem sempre a pessoa que movimenta o corpo da vítima pretende ocultar um crime ou suas provas. Há casos em que se dá o contrário, como para fazer crer que um suicídio foi um homicídio, por exemplo.

Essas marcas podem ser deixadas ou em relevo, nos solos menos rígidos, ou impressas com sangue, líquidos orgânicos, tintas e outros materiais. Não é usual a utilização de moldes, mas o levantamento fotográfico ou por desenho em escala deve ser feito.

\subsubsection{Marcas deixadas por peças de vestuário}

Quando a roupa é pressionada contra uma superfície lisa e polida pode eventualmente deixar uma impressão latente, produzida do mesmo modo que uma impressão papilar ou de luva. Se a peça estiver contaminada com sangue, outro material biológico ou tinta, a impressão será visível a olho nu. Se o suporte for de consistência

\footnotetext{
${ }^{94}$ SVENSSON, Arne; WENDEL, Otto. op. cit., p. 92.
} 
pastosa (tinta fresca, cimento fresco, areia, lama, etc.) a peça de vestuário deixará uma marca em baixo relevo, como ocorre com as pegadas.

Todas essas marcas devem ser fotografadas com uma escala colocada ao lado. Em alguns casos muito raros poderá ser utilizada a modelagem ${ }^{95}$.

As marcas e impressões produzidas por peças de vestuário podem servir de elemento de identificação ou orientação pela análise da estrutura do tecido, tipo de costura, defeitos e abrasões, modelo de botão ou fecho utilizado, etiquetas de marca, jóias e outros, quando possível seu levantamento ${ }^{96}$.

\subsubsection{Fragmentos de pele e anexos}

A pele é um dos maiores órgãos do corpo humano, atingindo cerca de $16 \%$ do peso corporal. Tem por funções principais: a proteção do organismo contra microorganismos patogênicos e raios ultravioleta, minimizar a perda de água pela evaporação, atuar como órgão sensorial (tato), auxiliar os mecanismos de termorregulação e excretar algumas substâncias.

É composta de duas camadas, a epiderme, mais externa, e a derme, formada por tecido conjuntivo. Abaixo da derme encontramos a hipoderme, que tem a mesma natureza da derme, mas não faz parte da pele, apenas servindo de sustentação e união com os tecidos adjacentes.

Como anexos ou fâneros $^{97}$, a pele apresenta glândulas (sudoríparas e sebáceas), pêlos e unhas, todos de grande importância para a perícia, principalmente no que toca ao estudo das impressões papilares.

Fragmentos de pele, unhas, cabelos e pêlos são achados mais ou menos freqüentes em locais de crime, particularmente em homicídios e crimes sexuais, e sempre serviram como princípio de prova para a identificação de criminosos $^{98}$.

\footnotetext{
${ }^{95}$ A modelagem somente será possível em marcas em relevo deixadas sobre superfícies horizontais ou levemente inclinadas. A modelagem de marcas deixadas em planos verticais é muito difícil e quase sempre danifica o modelo. Se for tentada, antes deve ser feito um minucioso levantamento fotográfico.

${ }^{96}$ Ver, também, o item 2.6.4.33: "Peças de vestuário e acessórios".

${ }^{97}$ Estruturas protetoras derivadas da epiderme.

${ }^{98}$ Almeida Júnior relata o caso do assassinato de Germaine Bichon (Paris, 1909), solucionado porque nas mãos da vítima foram encontrados fios de cabelo da assassina, a mulher Bosh (ALMEIDA JR., A. Lições de medicina legal. 4. ed. São Paulo: Nacional, 1957. p. 99).
} 
Com a evolução dos exames de identificação pelo DNA, entretanto, esses vestígios mostram-se de capital importância para a determinação da autoria do crime. Uma vez recolhidos, devem ser preservados adequadamente e encaminhados rapidamente ao laboratório para análise.

Os fragmentos de pele e anexos podem ser encontrados nas armas e instrumentos do crime, em móveis e objetos, ou no próprio corpo da vítima ou do autor.

Quando estão impregnados nas armas e instrumentos do crime geralmente pertencem à vítima e assumirão importância quando essas armas e instrumentos forem encontrados na posse do pretenso autor do delito.

Os vestígios coletados de móveis e objetos podem pertencer tanto à vítima como ao autor, sendo recomendável o cotejo com ambos. O encontro de fios isolados de cabelo em almofadas, cobertas de cadeiras, roupas de cama ou cortinas pode indicar a posição em que estava a vítima ou o acusado no momento do crime ${ }^{99}$.

Os materiais recolhidos do corpo da vítima, em regra, pertencem ao autor. São comuns os achados de fragmentos de pele sob as unhas, cabelos entre os dedos e pêlos pubianos do autor na região genital do ofendido ${ }^{100}$. Embora raro, pode ser pesquisada a cavidade bucal da vítima em busca de retalhos de tecido do criminoso.

Jobim, Costa e Silva ${ }^{101}$ recomendam que os pêlos e fibras, eventualmente existentes nas mãos da vítima, sejam recolhidos com pinça e que o bordo superior das unhas seja recortado para pesquisa de possíveis resquícios de restos de sangue e pele.

Os cabelos e pêlos com raiz apresentam uma quantidade de 1 a 750 nanogramas ${ }^{102}$ de DNA por bulbo e podem também ser recolhidos para identificação por esse processo. Mesmo não apresentando bulbo ${ }^{103}$, devem ser recolhidos como prova de orientação.

\footnotetext{
99"'Por ocasião do assassínio da Senhora Gouin, em um compartimento de vagão de estrada de ferro (Lion, 1909), a descoberta de um único fio de cabelo da vítima, no encosto do assento, permitiu a Balthazard determinar a posição que ela ocupava antes do crime" (ALMEIDA JR., A. op. cit., p. 100).

${ }^{100}$ É possível, inclusive, o encontro de pêlos pubianos do autor impactados no colo uterino, para ali direcionados pela penetração peniana (TEIXEIRA, Wilmes Roberto G. Sexologia forense. Mogi das Cruzes: Universidade Braz Cubas, 1995. p. 15. Apostila do Curso de Medicina Legal da Universidade Braz Cubas).

${ }^{101}$ JOBIM, Luiz Fernando; COSTA, Luís Renato; SILVA, Moacyr. Identificação humana. Campinas, SP: Millennium, 2006. p. 93. (Tratado de Perícias Criminalísticas. Organizador: Domingos Tochetto, v. 2).

${ }^{102}$ Nanograma (ng) - unidade de medida equivalente a $10^{-9}$ (um bilionésimo) de grama.

${ }^{103}$ Os cabelos e pêlos arrancados ou que caíram normalmente apresentam bulbo, os cortados não. Os fios arrancados geralmente apresentam células de tecido conjuntivo aderidas aos bulbos, ao passo que as raízes dos fios que caíram normalmente mostram-se livres de aderências.
} 
Por fim, podem ser encontrados tecidos, cabelos e pêlos da vítima no corpo do autor, mas sua recolha e pesquisa é bastante difícil porque além de reclamar celeridade, no nosso sistema jurídico depende de consentimento.

\subsubsection{Amostras ou manchas de líquidos ou secreções orgânicas}

Manchas são todas as modificações de cor, toda sujidade, toda deposição de material estranho, visível ou não à vista desarmada, que podem ser encontradas nos pisos e paredes, mobiliário, instrumentos, corpo e vestes do autor e da vítima, constituindo elementos de grande importância médico-legal e criminalística.

Vimos que no local do fato submetido à perícia podem ser encontradas amostras e manchas de líquidos ou secreções orgânicas, deixadas pelo ser humano ou por animais (sangue, suor, saliva, esperma, fezes e outras), e amostras e manchas de origem inorgânica (terra, lama, pólvora, ferrugem, substâncias graxas, etc.).

As manchas encontradas nos locais submetidos a exames periciais são de interesse sob dois aspectos principais: a natureza da substância que as produziu e a forma como se apresentam $^{104}$.

É importante que os delegados de polícia, magistrados, promotores de justiça e advogados conheçam as questões relacionadas com a perícia das manchas, as dificuldades enfrentadas pelos técnicos e, sobretudo, as questões que podem ser colocadas aos peritos para esclarecimento.

Dentre as inúmeras manchas de origem orgânica que podem ser objeto de estudo médico-legal merecem destaque:

\begin{tabular}{|ll}
\hline - sangue & - mecônio \\
- esperma & • secreções uretrais \\
- suor & • fezes \\
- colostro & - secreções vaginais \\
- leite & - urina \\
- muco nasal & - substâncias graxas \\
- saliva & - secreção emética \\
- secreções bronquiais & - secreção purulenta \\
\hline
\end{tabular}

${ }^{104}$ DOREA, Luiz Eduardo. As manchas de sangue como indício em local de crime. 2. ed. Porto Alegre: Sagra Luzzatto, 1995. p. 11. 


\subsubsection{Manchas e deposições de sangue}

A presença de manchas ou deposições de sangue no local do fato é um forte indicativo da ocorrência de crime ${ }^{105}$, embora nem sempre isso seja verdadeiro. Há casos de acidentes ou outros irrelevantes penais, como suicídios, em que grandes quantidades de sangue podem ser encontradas.

Nos crimes, por óbvio, o estudo da localização, distribuição e forma das manchas e deposições hematóides é importantíssimo para aquilatar a natureza da ocorrência e a dinâmica do fato.

O encontro de deposições sangüíneas denuncia a mudança de posição do corpo, a ocorrência de luta, a tentativa de mascarar o local para a perícia, o veículo utilizado para a remoção do cadáver, a presença do agente no local e outras circunstâncias de interesse.

O estudo das manchas sangüíneas divide-se em dois grandes campos: as observações de local e os exames laboratoriais. No local, estuda-se a localização, a quantidade e dinâmica das deposições. No laboratório, perquire-se sobre a natureza da substância colhida, ou seja, se realmente trata-se de sangue, em caso positivo, se é humano, qual o tipo sangüíneo, de que região do corpo proveio e há quanto tempo estava no local.

Se necessário, e dependendo da quantidade, o sangue poderá servir como elemento preciso de identificação pelo DNA.

\subsubsection{O estudo das manchas de sangue no local do fato}

O sangue é um tecido líquido que, operando como sistema de transporte, fornece substâncias nutritivas e oxigênio para os demais tecidos do corpo.

$\mathrm{Na}$ forma circulante ou recém-extraído de um vaso sangüíneo, tem coloração vermelha, é opaco, viscoso, alcalino, salgado ao paladar, com uma densidade entre 1,045 e $1,075 \mathrm{~g} / \mathrm{ml}$, tem ponto de congelamento entre 0,51 e $0,61{ }^{\circ} \mathrm{C}$, com odor particular e em alguns casos específicos para a espécie animal. Microscopicamente apresenta uma porção

\footnotetext{
${ }^{105}$ As manchas de sangue podem ser encontradas em vários tipos de crime, desde o homicídio, infanticídio, aborto e lesões corporais, até os crimes sexuais e patrimoniais como o roubo e o furto.
} 
líquida (plasma) e outra sólida, composta dos chamados elementos figurados (hemácias, leucócitos e plaquetas ou trombócitos) ${ }^{106,107 .}$

Inicialmente é preciso saber onde procurar o sangue e como identificá-lo.

As manchas têm características diferentes conforme sejam recentes ou antigas, variando também de acordo com o suporte sobre o qual se encontrem.

Nas roupas brancas e em suportes claros e absorventes, aparecem com contornos muito nítidos, pela sua característica de penetrar nas fibras dos tecidos. Nas roupas escuras as manchas são muito difíceis de distinguir, principalmente se forem antigas.

Como bem adverte Dorea $^{108}$, o suporte sobre o qual se localizam as manchas de sangue é um detalhe importante a ser observado no estudo desses indícios. Algumas superfícies podem alterar a forma original da mancha, quer porque irregular, quer porque absorvente ou ainda porque está impregnada de água ou outra substância que interagindo com o sangue, altera sua consistência e coloração.

Quanto à coloração, as manchas recentes são vermelhas e úmidas. Uma vez removidos dos vasos sangüíneos e deixados ao ar livre, os elementos figurados separam-se do plasma sob a forma de coágulo. A coloração, pela transformação da hemoglobina em metahemoglobina e finalmente hematina, vai escurecendo progressivamente, passando do vermelho acastanhado para castanho-escuro.

O sangue seco pode ter uma aparência fendilhada, parecendo ser formado por pequenas escamas brilhantes de reflexo esverdeado. Se a substância estiver impregnando paredes pintadas ou empapeladas, pode ocorrer uma reação química com os pigmentos da tinta, alterando a coloração da mancha ${ }^{109}$.

O tempo de exposição ou idade da mancha, além da coloração, pode ser estimado pela solubilidade, que diminui com o passar do tempo.

A quantidade de sangue encontrado no local pode dar uma idéia da gravidade dos ferimentos experimentados pela vítima ou pelo autor.

\footnotetext{
${ }^{106}$ ZARZUELA, José Lopes. Temas fundamentais de criminalística. Porto Alegre: Sagra DC Luzzatto, 1996. p. 87.

${ }^{107}$ Colocadas essas características principais, a fisiologia do sangue não vai nos interessar no momento, e será estudada oportunamente.

${ }^{108}$ DOREA, Luiz Eduardo. op. cit., p. 47.

${ }^{109}$ ALMEIDA JR., A. op. cit., p. 80.
} 
Por vezes as manchas de sangue são evidentes, mas em alguns casos o perito deve procurá-las com atenção, principalmente se houve alguma tentativa de maquiar o local.

Tendo acesso ao suspeito, antes que ele possa desfazer-se de suas vestes, o sangue deve ser buscado no interior dos punhos, nas dobras das camisas, bolsos das calças, lenços, bonés, bordas e solas dos calçados, atrás dos cintos, em pochettes, jóias e relógios, cabelos, barba, sob as unhas e outros (figura 4).
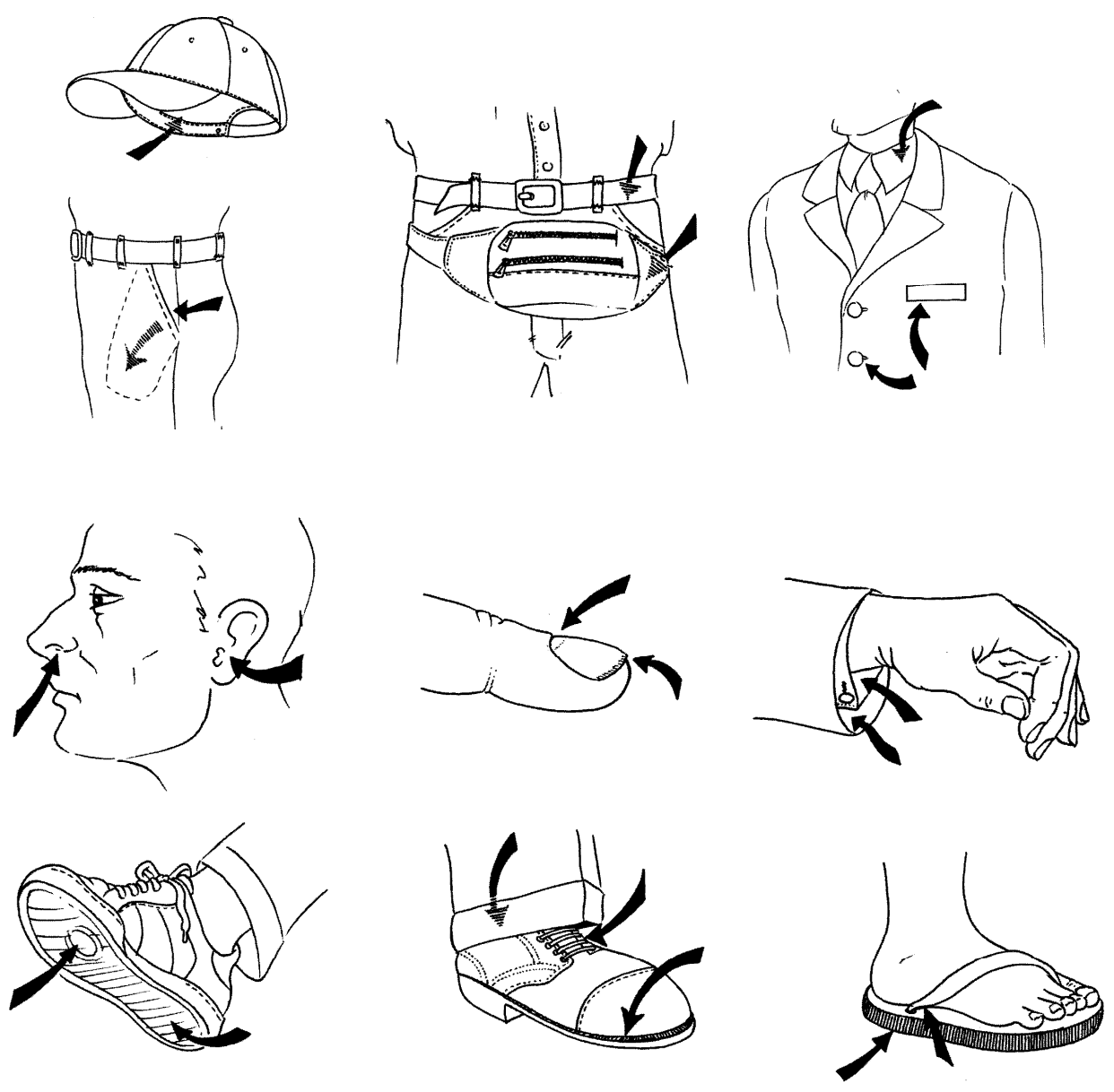

Figura 4 - Prováveis locais de encontro de manchas sangüíneas no corpo.

No local, é possível encontrar deposições hematóides nas juntas e frestas do assoalho, maçanetas, registros de torneiras, no sifão das pias, nos cantos dos móveis, tapetes, almofadas, cortinas, toalhas, cestos de lixo e outros locais de difícil acesso para remoção (figura 5). 


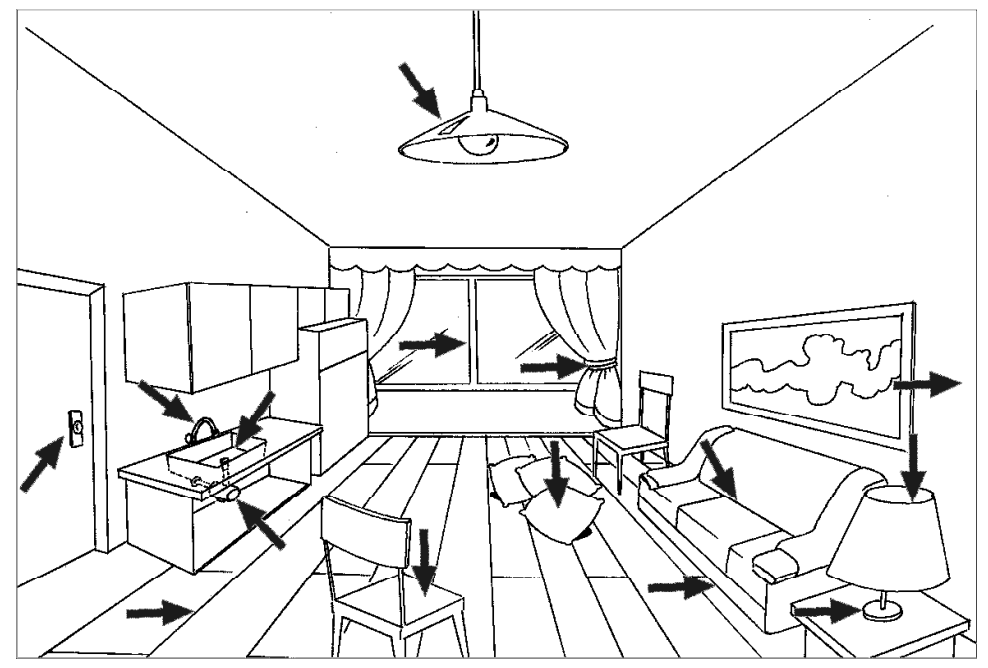

Figura 5 - Prováveis locais de encontro de manchas sangüíneas no local.

Procura-se, também, nas armas e possíveis instrumentos do crime, assim como em cordas, fios e correias que podem ter sido utilizados para imobilização do ofendido.

Nos veículos, os locais mais promissores são: o porta-malas, a calha de encaixe do estepe, o espaço sob os bancos, o assoalho debaixo dos tapetes e todas as frestas difíceis de limpar para onde o sangue possa ter escorrido ${ }^{110}$. Em se tratando de atropelamento, devem ser vistoriados, também, o pára-choque, as grades, os faróis e as lanternas, assim como toda a parte inferior do transporte (figura 6).

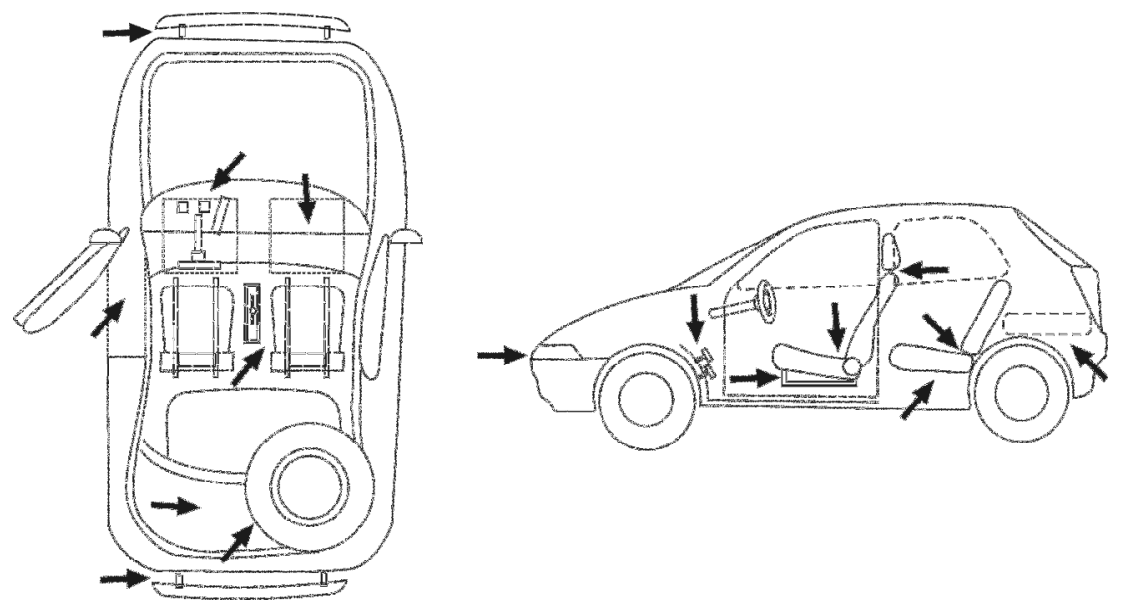

Figura 6 - Prováveis locais de encontro de manchas sangüíneas em automóveis.

\footnotetext{
${ }^{110}$ Certa feita um perito criminal do Instituto de Criminalística conseguiu encontrar resquícios de sangue no interior da lanterna traseira de um veículo, em cujo porta-malas a vítima havia sido transportada.
} 
Uma vez localizadas todas as manchas, é importante fazer uma análise de sua distribuição topográfica, umas em relação às outras, buscando estabelecer a dinâmica da perda sangüínea. Essa análise pode indicar se o corpo foi removido, a posição da vítima quando recebeu os ferimentos e se depois de ferida conseguiu ou não se mover. Sendo o sangue identificado como o do autor, poderá ser estabelecida sua rota de fuga, bem como alguns atos praticados após o crime.

Essas considerações serão de fundamental importância quando cotejadas com os testemunhos em juízo ou quando da realização de uma reconstituição.

A morfologia das deposições é muito variada. Segundo o mecanismo de formação, e cotejando as classificações propostas por $\operatorname{Simonin}^{111}$, Gómez ${ }^{112}$, e Dorea ${ }^{113}$, podemos dividir as manchas de sangue em:

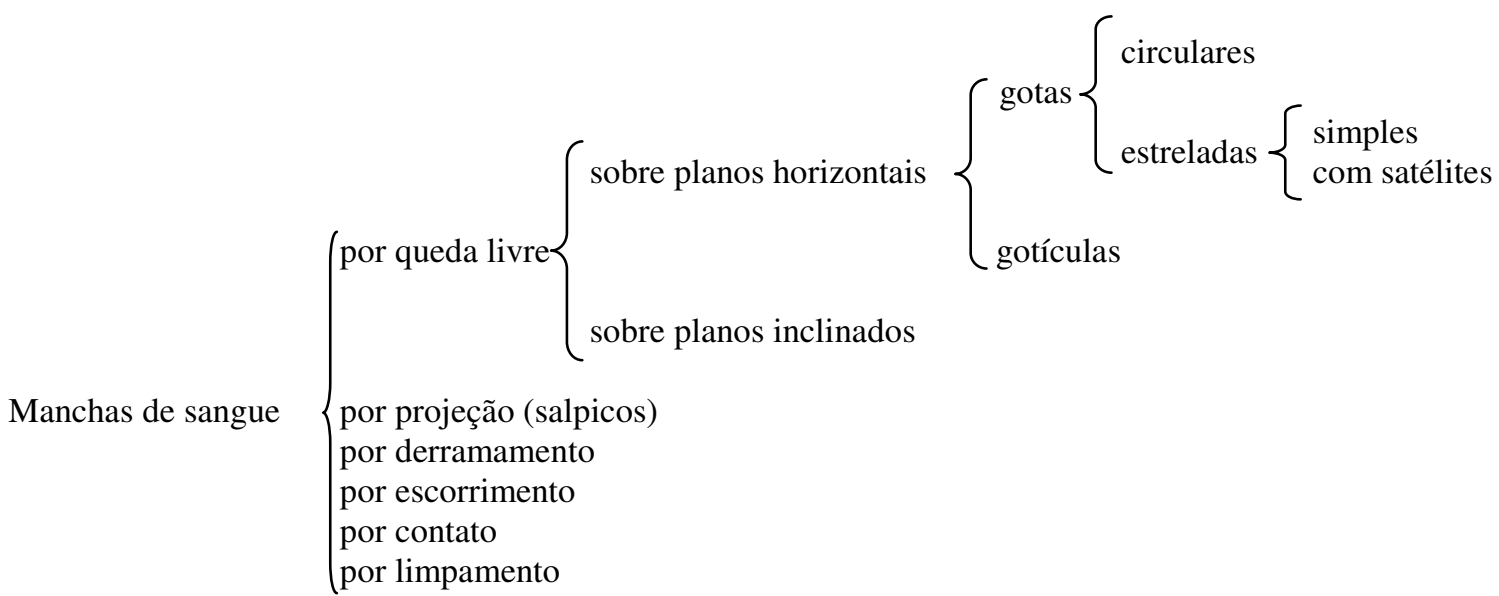

Nas manchas por queda livre sobre planos horizontais o sangue atinge o piso ou outro anteparo, impulsionado apenas pela ação da gravidade. Na dependência da altura, as manchas produzidas formarão gotas ou gotículas de conformação circular, conforme o quadro abaixo (figura 7):

\begin{tabular}{|l|l|c|}
\hline \multicolumn{1}{|c|}{ Altura } & \multicolumn{1}{|c|}{ Forma } & Ilustração \\
\hline De 5 a $10 \mathrm{~cm}$ & Circular, sem espículas. & A \\
\hline Entre 10 e $40 \mathrm{~cm}$ & Estrelada simples, sem gotas satélite. & B \\
\hline Entre 40 e $125 \mathrm{~cm}$ & Estrelada com gotas satélite. & C \\
\hline Acima de $125 \mathrm{~cm}$ & $\begin{array}{l}\text { As gotas de sangue que caem de uma altura considerável sobre } \\
\text { superfícies duras praticamente se desfazem, formando } \\
\text { gotículas esparsas. }\end{array}$ & D \\
\hline
\end{tabular}

${ }^{111}$ SIMONIN, Camille. Medicina legal judicial. Barcelona: Jims, 1962. p. 886.

${ }^{112}$ LÓPEZ GÓMEZ, Leopoldo. Técnica médico-legal criminalística. Valencia: Editorial Saber, 1953. p. 7.

${ }^{113}$ DOREA, Luiz Eduardo. op. cit., p. 41-43. 

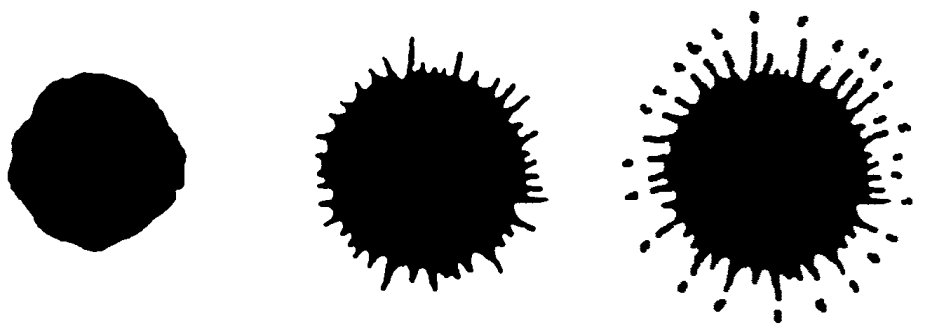

B

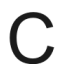

A

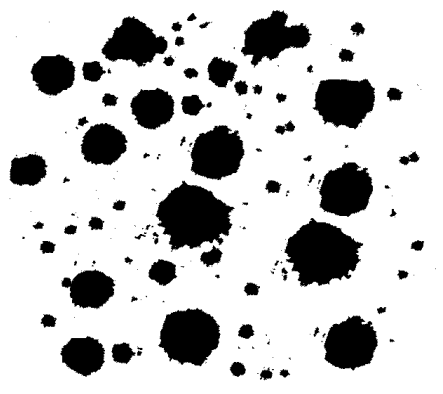

Figura 7 - Morfologia das gotas de sangue em queda livre sobre planos horizontais.

Se o anteparo for oblíquo, a configuração das manchas não será circular. Inicialmente a gota se expande e depois o sangue desce para a parte inferior alargando-se. O líquido concentra-se na parte mais baixa, formando uma massa ovóide que, ao descer, vai diminuindo de espessura. Em tal momento, o sangue permanece nas bordas da mancha, ficando claro no centro, onde é possível distinguir uma série de pequenas ondulações. Conforme a inclinação do plano, a mancha em sua trajetória descendente irá se alargando mais e mais na parte inferior até que se resolve em várias prolongações mais ou menos afiladas (figura 8$)^{114}$.

Além disso, existe sempre uma pequena gota supranumerária que desce com um atraso de 27/500 de segundo e que, se o plano for muito oblíquo, pode cair ao lado da principal deixando uma marca característica ${ }^{115}$.

É claro que, na dependência da altura de projeção, também sobre os planos inclinados a mancha poderá assumir uma configuração inicial estrelada, mas a principal característica será a do posterior deslocamento e escorrimento.

Nas manchas por projeção sobre planos horizontais, além da gravidade, atua sobre a gota outra força que lhe dá deslocamento lateral. Na dependência da intensidade dessa segunda força, a mancha será mais ou menos alongada e as espículas estarão orientadas no sentido do deslocamento. Como regra, quanto mais agudo for o ângulo em relação ao solo, mais rápido é o deslocamento da origem do sangue derramado.

O achado dessa forma de mancha pode indicar ${ }^{116}$ :

\footnotetext{
${ }^{114}$ LÓPEZ GÓMEZ, Leopoldo. op. cit., p. 12.

${ }^{115}$ Quando o plano é horizontal a gota supranumerária cai no centro da principal e não altera a sua conformação.

${ }^{116}$ Apud DOREA, Luiz Eduardo. op. cit., p. 42.
} 

a) pessoa ferida em movimento;
b) sangue que se projeta de artéria lesionada; e
c) movimento de instrumento, impregnado com considerável quantidade de sangue.

A ilustração seguinte traz alguns exemplos de variação do aspecto das manchas por projeção conforme a altura e o ângulo de inclinação:

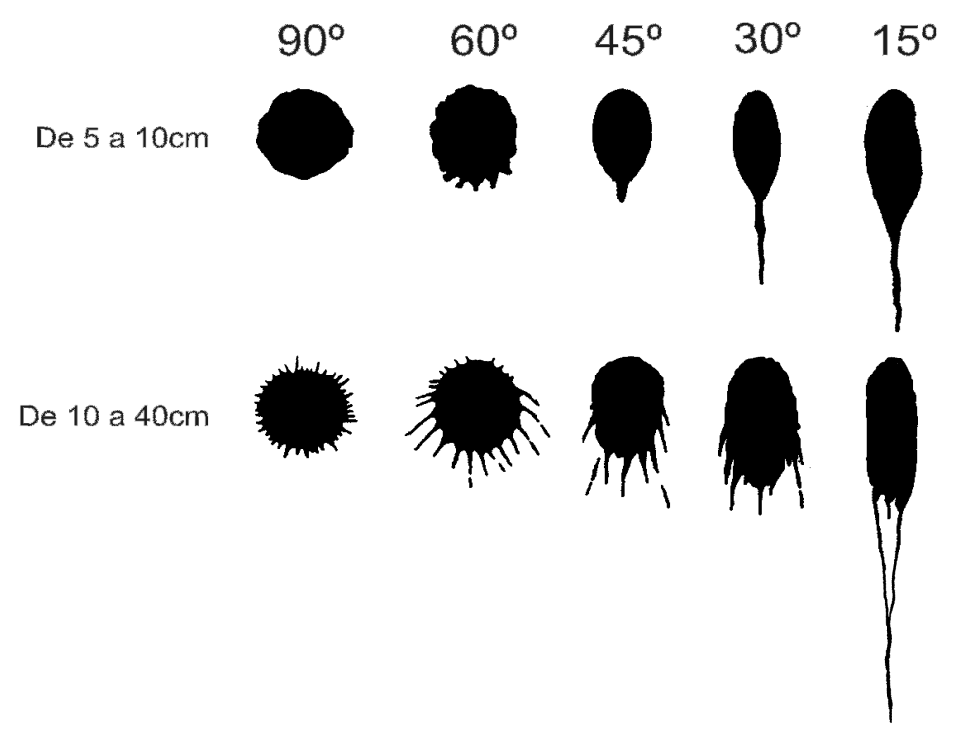

Figura 8 - Morfologia das gotas de sangue em queda livre sobre planos oblíquos.

No derramamento não há mancha propriamente dita, mas verdadeiros depósitos de sangue na forma de poças ou charcos. Nesses casos, geralmente, os ferimentos observados no corpo da vítima são bastante extensos.

As manchas por escorrimento são secundárias. O sangue inicialmente projetado ou depositado sobre móveis e paredes, desce pela ação da gravidade deixando verdadeiros rastros. Esses vestígios são importantíssimos porque podem indicar a mudança de posição do corpo da vítima ou de objetos, principalmente se o sangue já estiver seco e, portanto, imutável em sua posição.

As manchas por contato são deixadas, normalmente, por pés e mãos impregnados de sangue, quer da própria pessoa, quer de terceiros.

Manchas por impregnação são as encontradas em suportes como vestes, toalhas, cortinas, móveis estofados e outros materiais absorventes. 
Finalmente, as manchas por remoção ou limpamento vêm da tentativa de remoção. Comumente essas manchas aparecem sob a forma de esfregaços de dimensões variadas.

\subsubsection{Coleta das manchas e envio ao laboratório}

Todas as manchas encontradas no local devem ser fotografadas antes da coleta de amostras para encaminhamento ao laboratório.

Nas ainda úmidas, se possível, o objeto impregnado deve ser recolhido para envio ao laboratório, acondicionado em bolsas ou sacos plásticos.

As secas, se o suporte não puder ser remetido (paredes, móveis, etc.), precisam ser cuidadosamente raspadas e o pó acondicionado e identificado em envelopes de papel. Outra forma seria a de utilizar um $\operatorname{swab}^{117}$ umidificado com solução fisiológica ${ }^{118}$.

Havendo grande quantidade de sangue, recolher uma amostra significativa em tubo de ensaio.

Na hipótese de se pretender a identificação pelo DNA, lembrar que o sangue líquido apresenta uma quantidade de DNA disponível da ordem de 40 a 40 microgramas/ml e o seco 250 a 500 nanogramas $/ \mathrm{ml}$, requerendo uma quantidade maior ${ }^{119}$.

\subsubsection{O estudo das manchas de sangue no laboratório}

Analisada a dinâmica das manchas no local, em alguns casos é necessário encaminhar amostras da substância hematóide para o laboratório a fim de responder às seguintes indagações:

a) A substância recolhida é sangue?

b) O sangue pertence à espécie humana?

c) Qual o tipo sangüíneo a que pertence?

\footnotetext{
${ }^{117}$ Esfregaço feito com uma mecha de algodão estéril, geralmente enrolado em uma haste plástica ou de madeira.

${ }^{118}$ Solução de cloreto de sódio a $0,9 \%$.

${ }^{119}$ Apud JOBIM, Luiz Fernando; CoSTA, Luís Renato; SILVA, Moacyr. op. cit., p. 94.
} 
d) De que região do corpo procede o sangue?

e) Qual o volume da amostra?

f) Qual a idade da amostra?

g) A amostra pertence a determinada pessoa?

\section{Testes de orientação e certeza para sangue}

O sangue pode ser diagnosticado por intermédio de vários ensaios laboratoriais, alguns meramente probabilísticos (de orientação) e outros em que é possível afirmar a natureza da substância (de certeza).

As provas de orientação são extremamente sensíveis e permitem demonstrar traços de substância hematóide em diluições de até 1:200.000. A maioria das provas atualmente utilizadas baseia-se na presença de peroxidases no sangue, capazes de decompor um peróxido, liberando oxigênio nascente. Esse oxigênio oxida uma leucobase, produzindo a alteração de cor $^{120}$.

Os principais reativos para as provas de orientação, ainda utilizados, são:

a) Reativo de Adler: benzidina - coloração azulada;

b) Reativo de Amado Ferreira: benzidina - coloração esverdeada.

c) Reativo de Van Deen: tintura de guaico - coloração azulada;

d) Reativo de Thevenon \& Roland: piramidol - coloração arroxeada;

e) Reativo de Kastle-Meyer: fenolftaleína - coloração rosa;

f) Reativo de Kohn-O'Kelly: ortotoluidina - coloração verde-azulada;

g) Reativo de Furth-Michel, modificado por Madinger: leucobase malaquita coloração verde; e

h) Teste do luminol ${ }^{121}$ : luminol - coloração verde-azulada luminescente ${ }^{122}$.

${ }^{120}$ CALABUIG, J. A. Gisbert. op. cit., p. 1110.

${ }^{121} \mathrm{O}$ teste do luminol ainda não é utilizado pelo Instituto de Criminalística de São Paulo. Entendem os peritos que se trata de técnica de orientação para uso no local, a fim de indicar possíveis manchas de sangue. No laboratório, preferem os testes de Adler e Kastle-Meyer, que são realizados como rotina.

${ }^{122} \mathrm{O}$ luminol (5-amino 2,3-diidro 1,4-fitalazinodiona) é uma substância fluorescente, de fórmula química $\mathrm{C}_{8} \mathrm{H}_{7} \mathrm{~N}_{3} \mathrm{O}_{2}$, utilizada na pesquisa de cobre, ferro, peróxido e cianeto. Quando borrifado sobre uma superfície onde há partículas de sangue, o líquido reage com a hemoglobina e produz um brilho verde-azulado quando iluminado com luz ultravioleta, mesmo que o local tenha sido exaustivamente lavado. O produto já é fabricado no Brasil, pelo trabalho pioneiro da Universidade Federal do Rio de Janeiro, e apresenta uma sensibilidade de 1:1.000.000.000, cerca de mil vezes superior à do congênere norte-americano. 
Alguns autores não reconhecem valor às provas de orientação, pois se o volume da substância for suficiente, é melhor optar pela realização direta das provas de certeza. Duas situações práticas, entretanto, recomendam o uso dos testes de orientação, a inexistência de material suficiente para o ensaio de certeza e a fundada suspeita de que o referido material não é sangue.

Nesses casos os testes de orientação têm grande valor quando apontam resultados negativos, eliminando, pela sua sensibilidade, a possibilidade de a substância questionada ser sangue (humano ou não). Quando positivo o resultado, e possível, devem ser buscados outros ensaios de certeza.

\section{Testes de certeza}

As provas de certeza distribuem-se em quatro grupos: microscópicas, cristalográficas, espectroscópicas e cromatográficas.

Os ensaios microscópicos de certeza baseiam-se no encontro dos elementos constitutivos do sangue (humano ou animal). Embora os glóbulos brancos percam rapidamente suas características, os glóbulos vermelhos (hemácias), em condições normais, podem ser encontrados mais ou menos intactos nas manchas durante várias semanas.

O exame microscópico deve ser feito inicialmente na própria mancha, diretamente, com auxílio de iluminação lateral (epimicroscopia de Kalmus) e depois pela microscopia comum, sobre lâmina de vidro (diamicroscopia), restaurando-se a substância a ser analisada com soluções especiais.

Embora no exame microscópico, pelas características morfológicas das hemácias, seja, em tese, possível estabelecer o diagnóstico diferencial da espécie, isto é, se o sangue é humano ou animal, tal diferenciação, salvo situações muito especiais, é bastante temerária.

Em primeiro lugar as hemácias recolhidas de manchas estão em geral muito deformadas, não permitindo uma comparação precisa. Em segundo lugar, a diferença de diâmetro entre os glóbulos vermelhos dos mamíferos é pequena e pode levar à confusão, recomendando-se cautela no diagnóstico (ver quadro abaixo) ${ }^{123}$ :

\footnotetext{
${ }^{123}$ Apud LÓPEZ GÓMEZ, Leopoldo. op. cit., p. 70.
} 


\begin{tabular}{|l|c|}
\hline \multicolumn{1}{|c|}{ Espécie } & Diâmetro da hemácia \\
\hline Homem & 69 a $77 \mu$ \\
Cachorro & 66 a $73 \mu$ \\
Coelho & 60 a $69 \mu$ \\
Porco & 60 a $65 \mu$ \\
Boi & 56 a $60 \mu$ \\
Cavalo & 55 a $57 \mu$ \\
Carneiro & 45 a $59 \mu$ \\
Cabra & 40 a $46 \mu$ \\
\hline
\end{tabular}

A única característica morfológica segura, que permite a exclusão da espécie humana, é a presença de núcleo nos eritrócitos, caso em que se poderia afirmar a procedência de peixes, anfíbios, répteis ou aves, uma vez que as células vermelhas dos mamíferos são anucleadas (figura 9).

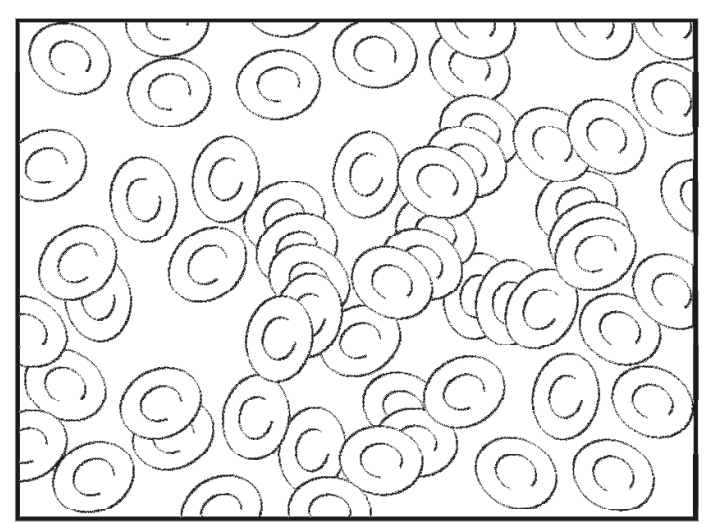

Hemácias humanas

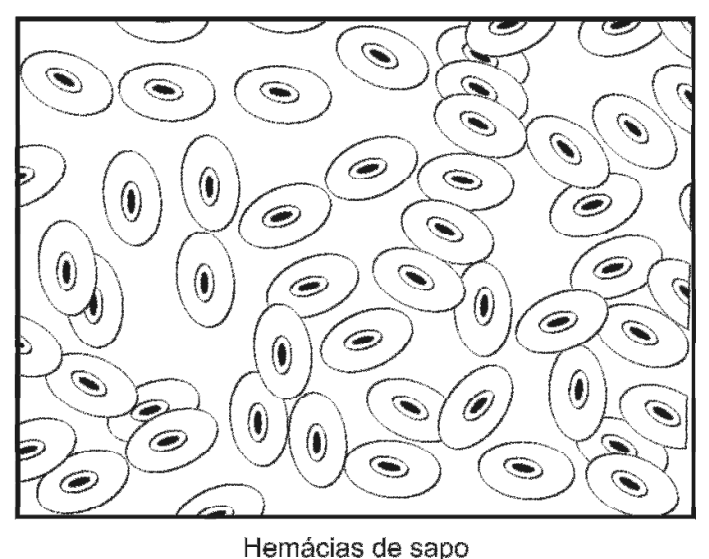

Hemácias de sapo

Figura 9 - Variação morfológica das hemácias.

A conformação dos eritrócitos também é diferente. Nos peixes, anfíbios, répteis e aves as células são elípticas enquanto que, na maioria dos mamíferos, excetuando os camelídeos, são em forma de disco achatado na porção central.

Das provas cristalográficas, as mais comuns são a pesquisa dos cristais de hemina ou cristais de Teichmann, e a pesquisa dos cristais de hemocromogênio (figura 10). 


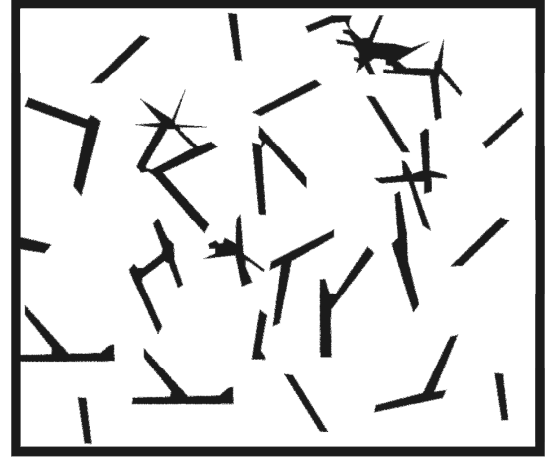

Cristais de Teichmann

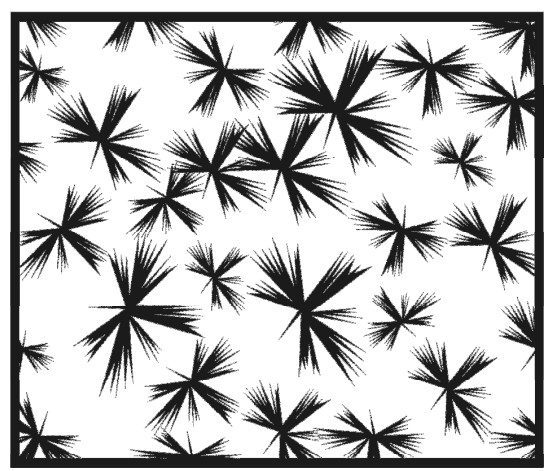

Cristais de hemocromogênio

Figura 10 - As provas cristalográficas mais comuns.

A espectroscopia tem por finalidade identificar o espectro de absorção da hemoglobina e alguns de seus derivados. A técnica consiste em fazer passar por uma solução filtrada do material suspeito, um feixe de luz branca, que depois é decomposto por um prisma. $\mathrm{O}$ espectro obtido será característico, pois a hemoglobina produzirá duas faixas negras no amarelo e no verde, aos 577 e $540,5 \mathrm{~nm}$, respectivamente.

Prossegue-se a pesquisa, alcalinizando a solução com potássio e algumas gotas de pirimidina, para análise da hematina alcalina, que deve produzir uma faixa de absorção no amarelo, aos $600 \mathrm{~nm}$.

Finalmente, adicionam-se algumas gotas de redutor (hidrogenossulfeto de amônio) à solução e procura-se o hemocromogênio, que produz faixas de absorção aos 559,5 e $530 \mathrm{~nm}$.

Somente com a determinação desses três elementos é que se poderá afirmar que a substância é sangue.

As provas cromatográficas $^{124}$ baseiam-se na propriedade que tem a hemoglobina de produzir uma mobilidade cromatográfica concreta quando em solução apropriada.

\section{Diagnóstico específico para sangue humano}

Determinada a natureza sangüínea da substância, é preciso certificar se o sangue é humano ou se provém de outra espécie animal.

\footnotetext{
${ }^{124}$ A cromatografia é um processo de separação de substâncias baseado no princípio químico da adsorção.
} 
Vimos que os eritrócitos dos peixes, anfíbios, répteis ou aves são elípticos e contêm núcleo e o achado de hemácias nucleadas, de plano, pode excluir a origem humana do sangue.

As provas de certeza para sangue humano, baseiam-se em testes de precipitação que buscam a sedimentação de proteínas existentes no sangue de determinada espécie animal, pela reação antígeno-anticorpo produzida por um soro específico ${ }^{125}$.

O princípio das provas é simples. Quando um animal é inoculado com uma proteína estranha ao seu organismo, por exemplo, a albumina humana, desenvolve anticorpos específicos contra essa proteína. O soro extraído do animal injetado torna-se capaz de aglutinar as hemácias e de precipitar in vitro amostras mínimas de células que contêm o agente sensibilizante.

Note-se que os testes não são propriamente específicos para sangue, mas apenas mostram que o material submetido ao teste possui a proteína indicada.

A mais tradicional dessas provas é a soroprecipitação de Uhlenhuth, que para alguns autores ${ }^{126}$, encontra-se obsoleta pela sua complexidade. As mais modernas são a reação de Vacher-Sulton e colaboradores ${ }^{127}$ e o teste de Ouchterlony.

\section{Diagnóstico individual}

Estabelecida a procedência humana do sangue, torna-se necessário saber se o material é proveniente ou não de certa pessoa. Em alguns casos é suficiente eliminar a possibilidade de pertencer a determinado indivíduo, em outros será necessário estabelecer uma identidade precisa.

Em geral, as provas de exclusão baseiam-se na determinação dos grupos e fatores sangüíneos (AOB, MN, Rh, P, Q, etc.) e as de identificação, quando possível, na análise do DNA.

A análise dessas técnicas foge ao escopo do presente trabalho.

\footnotetext{
${ }^{125}$ Método anafilático ou reação de Pfeiffer.

${ }^{126}$ CALABUIG, J. A. Gisbert. op. cit., p. 1112 e ZARZUELA, José Lopes. Temas fundamentais de criminalística, cit., p. 100-103. -

${ }^{127}$ É a técnica utilizada pelo Instituto de Criminalística de São Paulo como de certeza para sangue humano.
} 


\section{Diagnóstico topográfico}

O diagnóstico da região do corpo de onde procedeu o sangue pode ser feito pela pesquisa e identificação de elementos caracterizadores dos diversos tecidos ou órgãos, quer por intermédio de análise da citologia da região, quer pela aplicação de reagentes específicos.

Assim, no sangue menstrual, iremos encontrar células da mucosa uterina; no sangue proveniente de epistaxe $e^{128}$, células epiteliais com cílios vibráteis; na hemoptise ${ }^{129}$, células pulmonares; no sangue oriundo do estômago, teremos partículas alimentares e células da mucosa gástrica; no sangue da cavidade bucal, pode ser demonstrada a existência de células da mucosa bucal ou de saliva, pela aplicação do reagente de Ressner, e assim por diante.

Em alguns casos o diagnóstico topográfico será despiciendo, em outros poderá trazer elementos de convicção quando comparado aos testemunhos prestados ${ }^{130}$.

\section{Idade da amostra}

A determinação da idade de uma mancha de sangue geralmente é feita de forma bastante empírica. Em alguns casos, é praticamente impossível, em outros, permite uma aferição cautelosa.

A tarefa torna-se tão mais inexata quanto mais antiga for a mancha analisada. Uma vez seca, é praticamente inviável a determinação da idade do sangue. A umidade, o calor, a luz e o tipo de suporte são fatores que também influenciam a datação.

A determinação da idade de uma mancha de sangue depende do quanto estão adiantadas as alterações nos pigmentos sangüíneos. Se a hemoglobina transformou-se em hematina, por exemplo, a mancha pode não ser recente. Quão rapidamente essa mudança ocorreu depende de uma série de fatores que não podem ser totalmente aquilatados pelos $\operatorname{peritos}^{131}$.

\footnotetext{
${ }^{128}$ Sangramento ou hemorragia nasal - hemorrinia.

${ }^{129}$ Expectoração de sangue proveniente dos pulmões, traquéia ou brônquios. É comum na tuberculose pulmonar.

${ }^{130}$ Almeida Jr. lembra o caso de uma menina que alegava ter sido estuprada por determinado homem. Maska demonstrou que além de inexistirem lesões vaginais decorrentes da alegada violência, o sangue que manchava as vestes da pretensa vítima tinha origem uterina e não vaginal.

${ }^{131}$ SVENSSON, Arne; WENDEL, Otto. op. cit., p. 120.
} 
Em razão dessas dificuldades, alguns autores entendem que não se deve fazer prognósticos sobre a idade do sangue, declarando, no máximo, tratar-se de mancha recente ou antiga.

\subsubsection{Manchas de esperma}

As manchas de esperma têm grande importância médico-legal, principalmente em casos de crimes contra os costumes, e constituem uma prova de acusação irrefutável, principalmente depois do advento do exame de DNA que permite uma segura identificação do autor ${ }^{132}$.

O esperma ou sêmen é um líquido esbranquiçado, de odor sui generis ${ }^{133}$, composto de diversas frações secretadas pelos túbulos seminíferos e pelas glândulas acessórias ${ }^{134}$ genitais masculinas e que contêm os espermatozóides.

Em cada ejaculação o homem elimina entre 2 e $4 \mathrm{ml}$ de sêmen e 200 a 400 milhões de espermatozóides ${ }^{135}$, quantidade que diminui, tanto em volume quanto em número de espermatozóides, nas ejaculações subseqüentes dentro de um curto prazo de tempo ${ }^{136}$.

Nos locais, o sêmen pode ser encontrado ainda úmido ou, mais freqüentemente, sob a forma de manchas secas de aspecto característico ${ }^{137}$, sobre a pele, pêlos pubianos e do períneo das pessoas submetidas à prática de relações sexuais ou outros atos libidinosos, nas peças íntimas do vestuário, nas roupas de cama, toalhas, lenços, móveis e outros objetos relacionados ou que possam estar ligados ou ser utilizados para a prática sexual.

\footnotetext{
${ }^{132} \mathrm{O}$ líquido espermático em medicina legal pode ser encontrado sob a forma de manchas, impregnando tecidos; como líquido mesclado a outras secreções corpóreas, por exemplo, muco vaginal, ou sob a forma pura, quando recolhido diretamente de uma pessoa para exame de esterilidade.

${ }^{133} \mathrm{O}$ odor característico do sêmen é atribuído à presença de grande quantidade de substâncias ricas em derivados fosfatados. Esse odor pode ser percebido nas manchas recentes, mas desaparece com o tempo.

${ }^{134}$ Vesículas seminais, próstata e glândulas bulbo-uretrais.

${ }^{135}$ A concentração de espermatozóides varia de 70 a 100 milhões por mililitro de sêmen.

${ }^{136}$ Logo após a emissão, o esperma se coagula. Embora esse fenômeno seja universalmente conhecido, não se sabe ao certo qual o mecanismo. Essa característica é responsável pelo aspecto de "pano gomado" observado nas manchas de sêmen (MARANHÃO, Odon Ramos. Curso básico de medicina legal. 8 ed., 6 tir. São Paulo: Malheiros Ed., 2002. p. 102).

${ }^{137}$ Sobre tecidos absorventes o sêmen produz manchas de tonalidade acinzentada, de contornos irregulares e que dão ao suporte um aspecto apergaminhado. Sobre os objetos e tecidos não absorventes, formam, ao ressecamento, uma espécie de filme, escamas ou traços brilhantes. A fotografação deve ser feita preferencialmente colocando-se o suporte sobre fundo escuro.
} 
Excepcionalmente, a perícia pode recolher material do conduto vaginal ou outra sede corpórea, como nos casos de violência sexual.

Da mesma forma que o sangue, a pesquisa de esperma reclama provas de probabilidade ou orientação e provas de certeza.

\section{Provas de probabilidade para esperma}

A primeira delas é a aplicação de luz ultravioleta (lâmpada de Wood). A fluoresceína, presente no esperma, adquire uma coloração branco-azulada que tende para o amarelo à medida que a mancha vai envelhecendo ${ }^{138}$.

Esse teste não é específico porque a urina, muco nasal ou vaginal apresentam fluoresceína semelhante.

A observação dos cristais de Florence (figura 10) ou dos cristais de Barberio (cristais de picrato de espermina) também pode indicar a presença de esperma, embora essas provas, da mesma maneira, não sejam específicas, porque os cristais podem ser encontrados em outras secreções orgânicas ${ }^{139}$. Além disso, como bem advertem O'Hara \& Ostemburg ${ }^{140}$, por serem exames de orientação e não de certeza, os resultados, positivo ou negativo, não podem levar à conclusão de que a mancha analisada é ou não de esperma, uma vez que o tipo de suporte, a quantidade e qualidade da amostra ou a presença de substâncias interferentes podem ser falsos negativos ou positivos ${ }^{141}$.

\footnotetext{
${ }^{138}$ O Instituto de Criminalística de São Paulo utiliza essa técnica. É um bom exame para o perito de local, como orientação para coleta de amostras.

${ }^{139}$ Estes cristais podem ser observados também na saliva, secreções vaginais, muco uterino, bílis, leite, secreções purulentas, certos líquidos vegetais e líquidos que contêm colina (SIMONIN, Camille. Op. cit., p. 904).

${ }^{140}$ O'HARA, Charles E.; OSTEMBURG, James W. Criminalística: a aplicação das ciências físicas na descoberta de crimes. Rio de Janeiro: USAID, 1956. p. 463.

${ }^{141}$ Essas técnica, embora largamente difundidas pelos livros de Medicina Legal e Criminalística, são utilizadas como rotina nos laboratórios do Instituto de Criminalística, que prefere a pesquisa da fosfatase ácida como exame de orientação para esperma.
} 


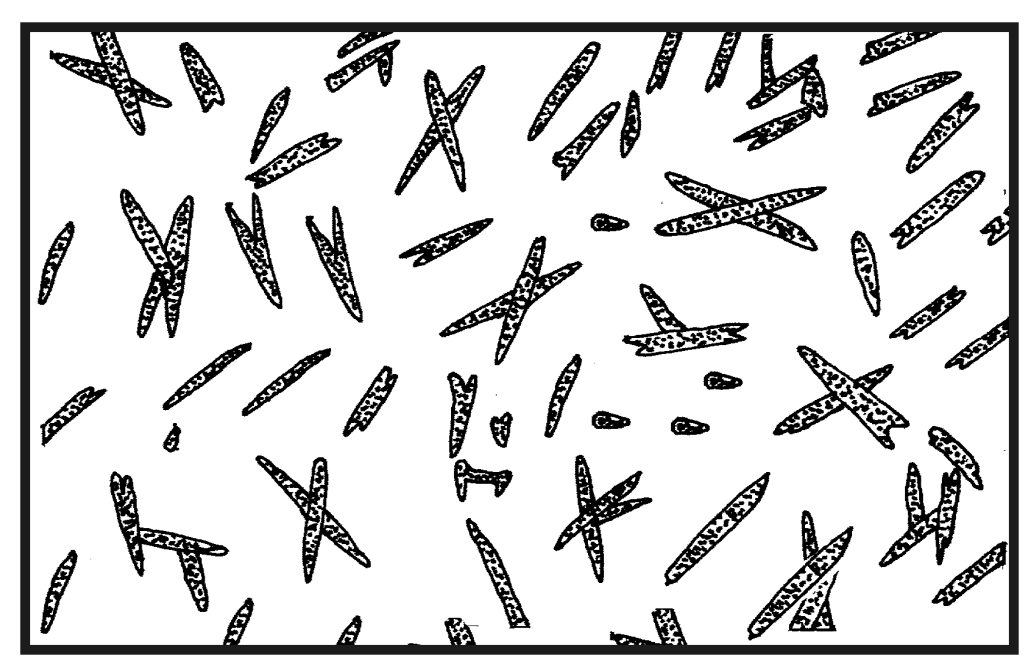

Figura 11 - Cristais de Florence.

Por derradeiro, como provas de orientação para esperma, temos a dosagem da fosfatase ácida e o teste de psa.

Embora presente em diversos líquidos orgânicos ${ }^{142}$, a fosfatase ácida aparece em grande quantidade no líquido prostático, uma das frações mais significativas do sêmen. Por essa razão é hoje empregada como técnica de preferência na maioria dos laboratórios de medicina legal como prova de orientação para esperma.

A pesquisa é bastante simples e atualmente utilizam-se kits comerciais para investigação da fosfatase ácida ${ }^{143}$.

O antígeno prostático específico $\left(\mathrm{PSA}^{144}\right)$ é uma enzima que, embora possa ser encontrada em células das glândulas parótidas, mamárias e do pâncreas, apresenta níveis sangüíneos que resultam exclusivamente da sua produção ao nível da próstata, fenômeno que transformou o PSA em marcador específico para as neoplasias malignas da próstata.

\footnotetext{
${ }^{142} \mathrm{O}$ esperma humano e dos primatas superiores contém elevadas quantidades de fosfatase ácida, entre 300 e 3.000 unidades King por mililitro, ao passo que os demais fluídos orgânicos (urina, saliva, suor, etc.) possuem concentrações infinitamente menores, da ordem de 5 unidades King por mililitro (ALMEIDA JR., A.; COSTA JR., J. B. de O. e. Lições de medicina legal. 21. ed. rev. e ampl. São Paulo: Nacional, 1996. p. 109).

${ }^{143}$ Essa é a técnica atualmente utilizada pelo Instituto de Criminalística de São Paulo, que aplica o kit da BIOCLIN para pesquisa de fosfatase ácida prostática, método colorimétrico de ponto final, baseado na coloração pela timolftaleína monofosfato (método de Roy modificado por Ewing \& Spitzed).

${ }^{144}$ Prostate specific antigen.
} 
Existem inúmeros kits comerciais para a dosagem plasmática do PSA que podem ser adaptados para exame das manchas de esperma ${ }^{145}$.

\section{Prova de certeza para esperma}

A prova de certeza para esperma baseia-se no encontro de espermatozóides. É claro que a ausência dos espermatozóides não exclui a possibilidade de a mancha ter sido produzida por líquido seminal. Existem diversas situações que vão desde a exigüidade da amostra e erros de técnica até situações orgânicas como a azoospermia ${ }^{146}$, que interferem no encontro de células.

Do ponto de vista médico-legal, Lecha Marzo orientou no sentido de que o encontro de cabeças ou caudas isoladas não permite diagnóstico conclusivo sobre a etiologia da mancha. Para afirmar que se trata de esperma, é preciso encontrar ao menos um espermatozóide inteiro ou cabeças com fragmento de cauda ${ }^{147}$.

O espermatozóide maduro na espécie humana divide-se anatomicamente em três partes: a cabeça piriforme, de aproximadamente $5 \mu \mathrm{m}$ de comprimento (que carrega o patrimônio genético), a parte intermediária, denominada colo ou corpo ${ }^{148}$, com $5 \mu \mathrm{m}$ de comprimento e a cauda, com cerca de $50 \mu \mathrm{m}$ de comprimento, que lhe dá mobilidade.

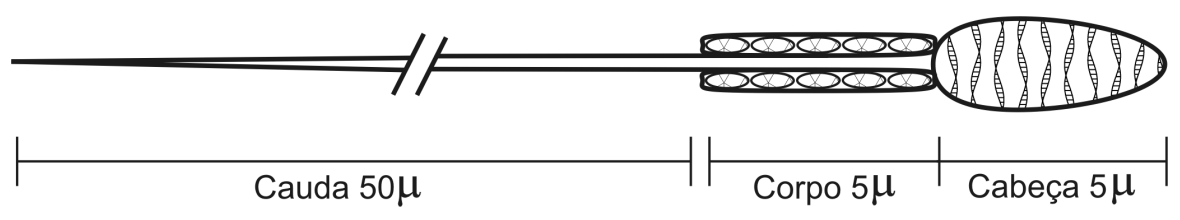

Figura 12 - Estrutura do espermatozóide.

O diagnóstico diferencial de espécie pode ser feito pela morfologia dos espermatozóides ou por reações de soroprecipitação, à semelhança dos procedimentos preconizados para o sangue humano.

\footnotetext{
${ }^{145}$ O Instituto de Criminalística de São Paulo já utilizou, por exemplo, o "PSA - One step test" da "LAB Diagnóstica", com bons resultados.

${ }^{146}$ Ausência de espermatozóides ativos no ejaculado. Não deve ser confundido com a aspermia ou aspermatismo que é a ausência de esperma.

${ }^{147}$ LÓPEZ GÓMEZ, Leopoldo. op. cit., p. 161.

${ }^{148} \mathrm{O}$ corpo contém mitocôndrias que produzem a energia motora do espermatozóide.
} 


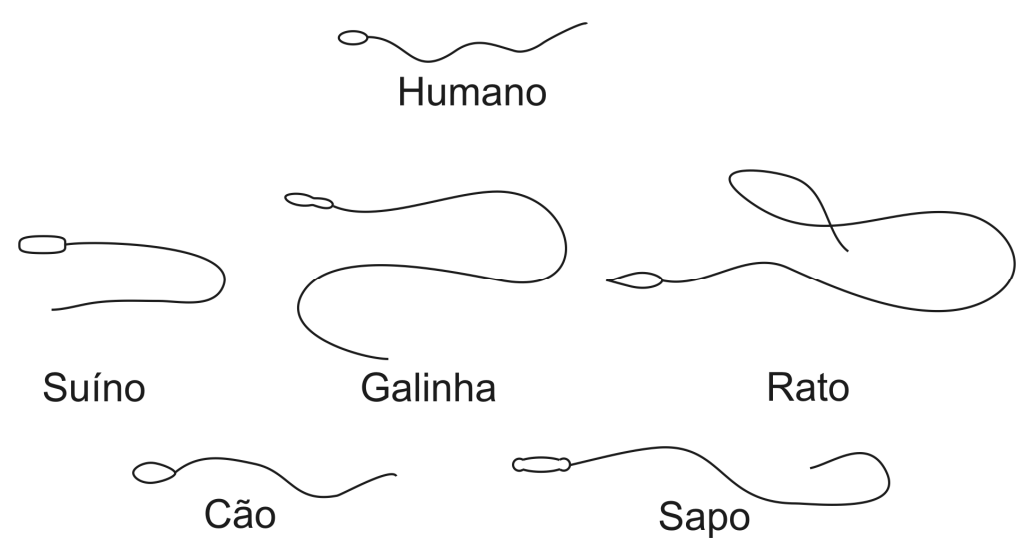

Figura 13 - Morfologia do espermatozóide em diferentes espécies animais.

A observação dos espermatozóides, como ensina Gómez, pode ser feita após prévia separação do suporte que contém a mancha ou diretamente, sem essa separação. Várias técnicas são preconizadas.

\subsubsection{Manchas de suor}

O suor é um líquido aquoso, incolor, de cheiro característico e sabor levemente salgado, secretado pelas glândulas sudoríparas. O encontro de manchas de suor nos locais de crime, principalmente em peças de vestuário, como lenços ou faixas de cabelo, deixadas pelo possível autor, podem se constituir importante prova de identificação.

O suor de qualquer parte do corpo oferece igual possibilidade de investigação e, dependendo da quantidade de material disponível, permite a identificação do grupo sangüíneo ${ }^{149}$ e, eventualmente, um estudo comparativo, já que a composição da secreção varia de pessoa para pessoa ${ }^{150}$.

O quadro abaixo indica alguns valores normais encontrados no suor humano ${ }^{151}$ :

\footnotetext{
${ }^{149}$ SVENSSON, Arne; WENDEL, Otto. op. cit., p. 140.

${ }^{150}$ DOREA, Luiz Eduardo; STUNVOLL, Victor Paulo; QUINTELA, Victor. Criminalística. 2. ed. Porto Alegre: Sagra Luzzatto, 2002. p. 85. (Tratado de Perícias Criminalísticas. Organizador: Domingos Tochetto).

${ }^{151}$ Apud GORINA, Alfonso Balcells. A clínica e o laboratório. 16. ed. (eletrônica) São Paulo: Medsi, 1996.
} 


\begin{tabular}{|l|c|}
\hline Ácido láctico & 45 a $452(225) \mathrm{mg} / 100 \mathrm{ml}$ \\
Ácido úrico & $0,7 \mathrm{a} 2,5(1-4) \mathrm{mg} / 100 \mathrm{ml}$ \\
Ácido pirúvico & $4,4 \mathrm{mg} / 100 \mathrm{ml}$ \\
Arginina & $3,5 \mathrm{mg} / 100 \mathrm{ml}$ \\
Cloro & $4 \mathrm{a} 60 \mathrm{mEq} / 1$ \\
Histidina & $8,0 \mathrm{mg} / 100 \mathrm{ml}$ \\
Nitrogênio total & 27 a $64(31) \mathrm{mg} / 100 \mathrm{ml}$ \\
Potássio & 3 a $10(11) \mathrm{mEq} / 1$ \\
Peso específico (densidade) & $1,001 \mathrm{a} 1,006$ \\
Sódio & $10 \mathrm{a} 80 \mathrm{mEq} / 1$ \\
Treonina & $5,4 \mathrm{mg} / 100 \mathrm{ml}$ \\
Tirosina & $3,2 \mathrm{mg} / 100 \mathrm{ml}$ \\
Uréia & 12 a $57(26) \mathrm{mg} / 100 \mathrm{ml}$ \\
pH & $3,8-5,6$ \\
\hline
\end{tabular}

\subsubsection{Manchas de saliva}

A saliva é um recremento ${ }^{152}$ produzido pelas glândulas salivares na proporção de 1 a 1,5 litros a cada 24 horas. Tem uma concentração de potássio cerca de quatro vezes superior e de sódio cinco vezes inferior às do plasma. Possui uma enzima específica, a amilase (ou ptialina), que permite a identificação da secreção.

O quadro abaixo indica alguns valores normais encontrados na saliva humana ${ }^{153}$ :

\begin{tabular}{|l|c|}
\hline Ácido úrico & $1,5 \mathrm{mg} / 100 \mathrm{ml}$. \\
Amilases & 80 a $625 \mathrm{U} / \mathrm{Wohlgemuth}$. \\
Cálcio & 4 a $10 \mathrm{mg} / 100 \mathrm{ml}$. \\
Cloro & 15 a $20 \mathrm{mEq} / \mathrm{l}=40-70 \mathrm{mg} / 100 \mathrm{ml}$. \\
Colesterol & 5 a $20 \mathrm{mg} / 100 \mathrm{ml}$. \\
Fósforo & $20 \mathrm{mg} / 100 \mathrm{ml}$ (inorgânico $14+$ orgânico 6). \\
Glicose & 12 a $28 \mathrm{mg} / 100 \mathrm{ml}$. \\
Mucina & 100 a $600 \mathrm{mg} / 100 \mathrm{ml}$. \\
Potássio & $20 \mathrm{mEq} / 1=81 \mathrm{mg} / 100 \mathrm{ml}$. \\
Proteínas & 20 a $200 \mathrm{mg} / 100 \mathrm{ml}$. \\
Reserva alcalina & 15 a 20 volumes de CO2/100ml. \\
Sódio & $14 \mathrm{mEq} / 1=33 \mathrm{mg} / 100 \mathrm{ml}$. \\
Uréia & 22 a $30 \mathrm{mg} / 100 \mathrm{ml}$. \\
pH & $6,3$. \\
\hline
\end{tabular}

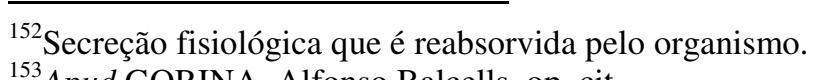

${ }^{153}$ Apud GORINA, Alfonso Balcells. op. cit. 
As manchas de saliva têm coloração variada que vão de amareladas a esbranquiçadas ou acinzentadas, de contornos mal definidos e não oferecem fluorescência à luz ultravioleta (lâmpada e Wood).

As provas químicas de orientação para manchas de saliva são:

a) pesquisa de sulfo-cianeto de potássio; e

b) reação de Boettger.

A prova de certeza é o exame microscópico, pelo encontro de células epiteliais pavimentosas típicas do epitélio bucal e faringe ou células prismáticas com cílios vibráteis, provenientes das vias respiratórias.

As manchas de saliva apresentam uma importância médico-legal muito grande. Podem estar relacionadas com uma extensa variedade de delitos e ser encontradas sob a forma de restos deixados por beijos ou mordidas, nos crimes contra a liberdade sexual, peças de vestuário utilizadas para amordaçar a vítima, lenços esquecidos pelo autor e outros materiais $^{154}$.

Em alguns casos, a partir da saliva de indivíduos secretores ${ }^{155}$, é possível determinar o grupo sangüíneo a que pertence (sistemas $\mathrm{ABO}$ e $\mathrm{S}^{156}$ ) e, em outros, pela presença de células de descamação da mucosa bucal, a identificação pelo DNA ${ }^{157}$.

A determinação do grupo sangüíneo é possível a partir de palitos de dentes, tocos de cigarros, selos postais, envelopes, garrafas, xícaras, copos e qualquer outro utensílio que tenha entrado em contato com os lábios. A sensibilidade do teste é tão grande que, nos secretores, é possível determinar o grupo sangüíneo com 1/16 de um selo postal ${ }^{158}$.

\footnotetext{
${ }^{154}$ Almeida Jr. lembra um interessante caso ocorrido em 1909, em Paris, onde "após crime de grande mistério, a Senhora Steinheil afirmou que lhe havia sido introduzido um chumaço de algodão na boca, mas o fato de não se achar saliva no algodão veio indicar que a alegação de violência era falsa" (ALMEIDA JR., A. op. cit., p. 110).

${ }^{155}$ Leone Lattes demonstrou, em 1931, que a saliva humana contém os mesmos aglutinogênios que se encontram no sangue do indivíduo. Entretanto, certas pessoas são secretoras, ou seja, em sua secreção salivar há grande quantidade desses aglutinogênios, e em outras não (ALMEIDA JR., A.; COSTA JR., J. B. de O. e. op. cit., p. 110).

${ }^{156} \mathrm{Em}$ 1932, Schiff \& Sasaki estudaram 50 famílias quanto à presença ou ausência na saliva de substâncias grupo-específicas hidro-solúveis do sistema $\mathrm{ABO}$ descobrindo a propriedade $\mathrm{S}$ - secretante (BEIGUELMAN, Bernardo. Genética de populações humanas. p. 80. Disponível em: $<$ http://lineu.icb.usp.br/ bbeiguel/Genetica\%20Populacoes/Cap.0.pdf>. Acesso em: 10 dez. 2006).

${ }^{157}$ A saliva possui de 1 a 10 microgramas/ml de DNA disponível (JOBIM, Luiz Fernando; CosTA, Luís Renato; SILVA, Moacyr. op. cit., p. 94).

${ }^{158}$ SVENSSON, Arne; WENDEL, Otto. op. cit., p. 139.
} 


\subsubsection{Manchas de mecônio}

Dá-se o nome de mecônio ${ }^{159}$ à substância pastosa, de cor esverdeada, algumas vezes estriada de amarelo, aderente e inodora, formada pelo conjunto de líquidos orgânicos procedentes de diversas partes do aparelho digestivo e que se acumulam, durante a gestação, no tubo intestinal do feto, constituindo as primeiras evacuações dos recémnascidos.

O mecônio começa a ser eliminado de 6 a 12 horas após o nascimento e prolongase por 2 a 3 dias, mas é possível ser expelido durante o parto, particularmente se ocorre sofrimento fetal.

A pesquisa de mecônio é importante para os casos de aborto, partos clandestinos e infanticídios. As manchas têm um aspecto untuoso de coloração amarelo-esverdeada. Com freqüência, em razão das circunstâncias que envolvem o seu encontro, as manchas de mecônio podem vir acompanhadas de sangue, líquido amniótico, unto sebáceo e restos placentários.

O mecônio, segundo Gómez ${ }^{160}$, é formado por elementos provenientes de três origens:

a) elementos de origem gastrointestinal - constituídos por muco, alguns grânulos inespecíficos e células de descamação do tubo digestivo;

b) elementos de origem hepática - muco, similar ao anterior; células cilíndricas de descamação das vias biliares; corpúsculos característicos denominados corpúsculos mecônicos, castanhos, de conformação esférica ou ovóide, com $5 \mu$ a $40 \mu$ de diâmetro; cristais de colesterina e outros cristais $^{161}$; e

c) elementos de origem amniótica - células epidérmicas (corpúsculos mecônicos brancos) e pêlos ou lanugem fetal ${ }^{162}$ que caem no líquido amniótico e, a partir do nono mês de gestação, são deglutidos pelo feto.

\footnotetext{
${ }^{159}$ Dá-se o nome de mecônio também ao suco esverdeado obtido da papoula para fabricação do ópio.

${ }^{160}$ LÓPEZ GÓMEZ, Leopoldo. op. cit., p. 177-178.

${ }^{161}$ Cristais de bilirrubina, taurina, ácido taurocólico e colina. Como diagnóstico diferencial, é importante frisar que o mecônio não contém, jamais, cristais de fosfato amônico-magnésico, presentes apenas nas fezes de pessoa adulta.

${ }^{162} \mathrm{O}$ cabelo do feto aparece por volta do terceiro mês e aos seis meses todo o corpo está coberto por um pêlo suave, não pigmentado e não medulado chamado lanugem. É produzido pelos folículos fetais e se desprende geralmente antes do nascimento, no útero, a partir do sétimo ou oitavo mês de gestação ou logo após o nascimento.
} 
Há um consenso entre os autores no sentido de que a composição química do mecônio inclui: mucosina, colesterina, pigmentos biliares, bilirrubina, biliverdina, ácidos graxos, esteárico e margárico, fórmico, ácidos biliares, taurocólico, glucocólico e colálico. As opiniões divergem quanto à presença de albumina, peptona, leucina, tirosina, ácidos e sais láticos ${ }^{163}$.

Para o diagnóstico da mancha de mecônio, também há provas de orientação ou probabilidade e de certeza.

Como provas de orientação pode-se citar, entre outras:

a) exposição à luz ultravioleta ${ }^{164}$;

b) reação de Gmelin;

c) reação de Hammersten;

d) reação de Sabatini;

e) reação de Marechal-Rosin; e

f) reação de Dastre - pesquisa de colesterina.

Como prova específica, procuram-se ao microscópio (figura 14) os elementos mencionados, principalmente os corpúsculos mecônicos (A), traços de muco (B), gotículas de gordura (C), pêlos da lanugem fetal (D), cristais de colesterina (E) células de procedência variada $(\mathrm{F})$ e granulações diversas $(\mathrm{G})$.

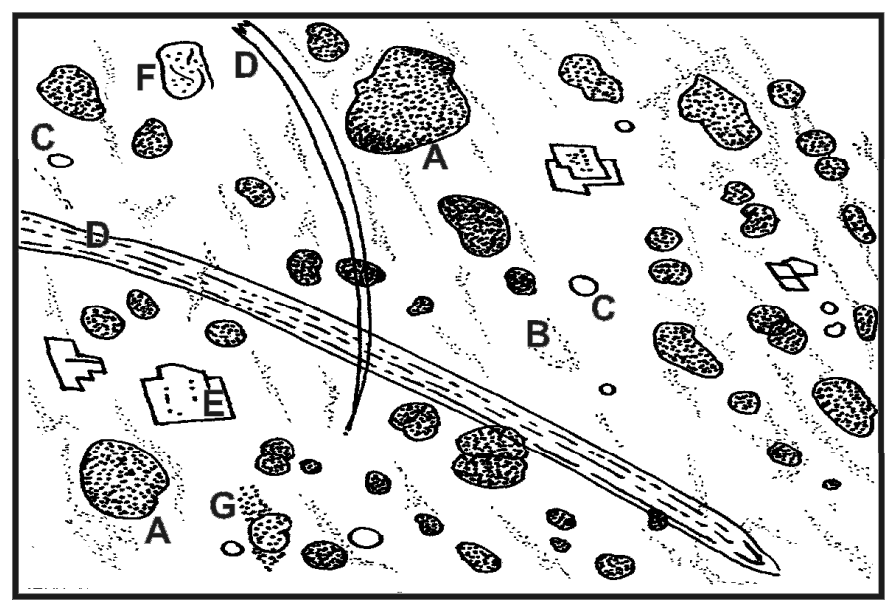

Figura 14 - Elementos microscópicos encontradiços no mecônio.

\footnotetext{
${ }^{163}$ Apud LÓPEZ GÓMEZ, Leopoldo. op. cit., p. 178.

${ }^{164}$ Dependendo dos contaminantes, as manchas de mecônio produzem fluorescências diversas quando expostas à luz ultravioleta (lâmpada de Wood). Essa prova, entretanto, carece de especificidade, pois outros líquidos orgânicos também produzem fluorescência nas mesmas condições.
} 
Segundo Gómez ${ }^{165}$, pelo exame microscópico é possível, inclusive, precisar aproximadamente a idade do feto:

\begin{tabular}{|l|l|}
\hline Em torno de 4 meses de vida intra-uterina & $\begin{array}{l}\text { Mecônio branco-acinzentado, sem pêlos, sem células de } \\
\text { descamação e sem cristais de colesterina. }\end{array}$ \\
\hline De 5 a 8 meses de vida intra-uterina & $\begin{array}{l}\text { Mecônio verde-amarelado, sem pêlos, sem células de } \\
\text { descamação e com cristais de colesterina. }\end{array}$ \\
\hline Feto a termo & $\begin{array}{l}\text { Mecônio verde-escuro, presença de lanugem fetal e } \\
\text { células epidérmicas de descamação, presença de cristais } \\
\text { de colesterina e ausência de gordura. }\end{array}$ \\
\hline Recém-nascido que tenha sido amamentado & Presença abundante de gordura \\
\hline
\end{tabular}

Excepcionalmente, poder-se-á perquirir se a mancha de mecônio é de origem humana ou animal. O diagnóstico diferencial da espécie pode ser feito pela observação dos pêlos deglutidos, que são diferentes para cada espécie animal, e também pela presença de glicose, ausente no mecônio humano e presente no dos solípedes ${ }^{166}$ e ruminantes ${ }^{167}$.

Não há técnica precisa para determinação da idade da mancha.

\subsubsection{Manchas e deposições de matéria fecal}

Um ser humano adulto normal elimina, em média e com a alimentação comum, entre 150 e $250 \mathrm{~g}$ de fezes por dia. Com regime vegetariano, chega-se a $370 \mathrm{~g}$, ou mais, enquanto com regime de carne apenas de $60 \mathrm{~g}$ diários. A composição e a consistência dependem basicamente dos resíduos alimentares provenientes da dieta e da presença de eventual quadro patológico gastrointestinal.

Deposições de tamanho e consistência variável de fezes humanas são achados mais ou menos freqüentes em locais de crime. Esse fato pode indicar o estado de excitação nervosa do criminoso, a demonstração de desprezo para com a vítima, um gesto de impunidade, superstição ${ }^{168}$ ou simples necessidade.

${ }^{165}$ LÓPEZ GÓMEZ, Leopoldo. op. cit., p. 182.

${ }^{166}$ Mamíferos ungulados com um único casco em cada pata, como o cavalo.

${ }^{167}$ LÓPEZ GÓMEZ, Leopoldo. op. cit., p. 183.

${ }^{168}$ Notadamente nos crimes patrimoniais. O criminoso defeca no local pela crença de que isso tornará o crime impune. 
O reconhecimento da natureza fecal da mancha ou da deposição não oferece dificuldade e geralmente é feito pelas suas características macroscópicas de cor e odor ${ }^{169}$. Pode-se, para maior precisão, realizar o exame microscópico que irá revelar a presença de resíduos alimentares e cristais diversos ${ }^{170}$.

Com exceção da possibilidade de identificação do grupo sangüíneo a que pertence o autor, o encontro de fezes no local dificilmente pode ser utilizado como meio de identificação.

Os resíduos de alimentos não totalmente digeridos, como fibras musculares estriadas (carne não digerida), corpos de Nothnagel (fibras musculares completamente digeridas, com desaparecimento das estrias), sementes, granulações de amido, gotículas de gordura, células, fibras e pêlos vegetais, dificilmente irão apontar a autoria do fato em questão, podendo fornecer, no máximo, idéia dos hábitos alimentares do autor (ver figura $15)^{171}$.

O encontro de fungos e parasitas intestinais, embora possa ser um elemento de exclusão e um forte indício de autoria, dificilmente poderá ser tido como determinante para a identificação, pois esses parasitas, notadamente os mais comuns ${ }^{172}$, podem ser encontrados em boa parcela da população.

\footnotetext{
${ }^{169}$ Para comprovação da natureza fecal da mancha, o Instituto de Criminalística de São Paulo procura determinar a presença de urobilinogênio. A técnica consiste em tratar a mancha com cloreto de zinco e cloreto de mercúrio e posterior exposição à luz ultravioleta (lâmpada de Wood).

${ }^{170}$ Os cristais encontrados nas fezes são resíduos das secreções das glândulas digestivas. Dentre eles, são freqüentes; cristais de hematoidina, e bilirrubina, romboédricos ou prismáticos e de coloração arroxeada; cristais de colesterina, retangulares e transparentes; cristais de Charcot-Leyden, pequenos, octaédricos e transparentes; cristais de oxalato de cal, octaédricos e cristais de fosfato-amônico-magnésico, grandes, prismáticos e incolores.

${ }^{171}$ Apud SIMONIN, Camille. op. cit., p. 908.

${ }^{172}$ Como oxiúros ou áscaris.
} 


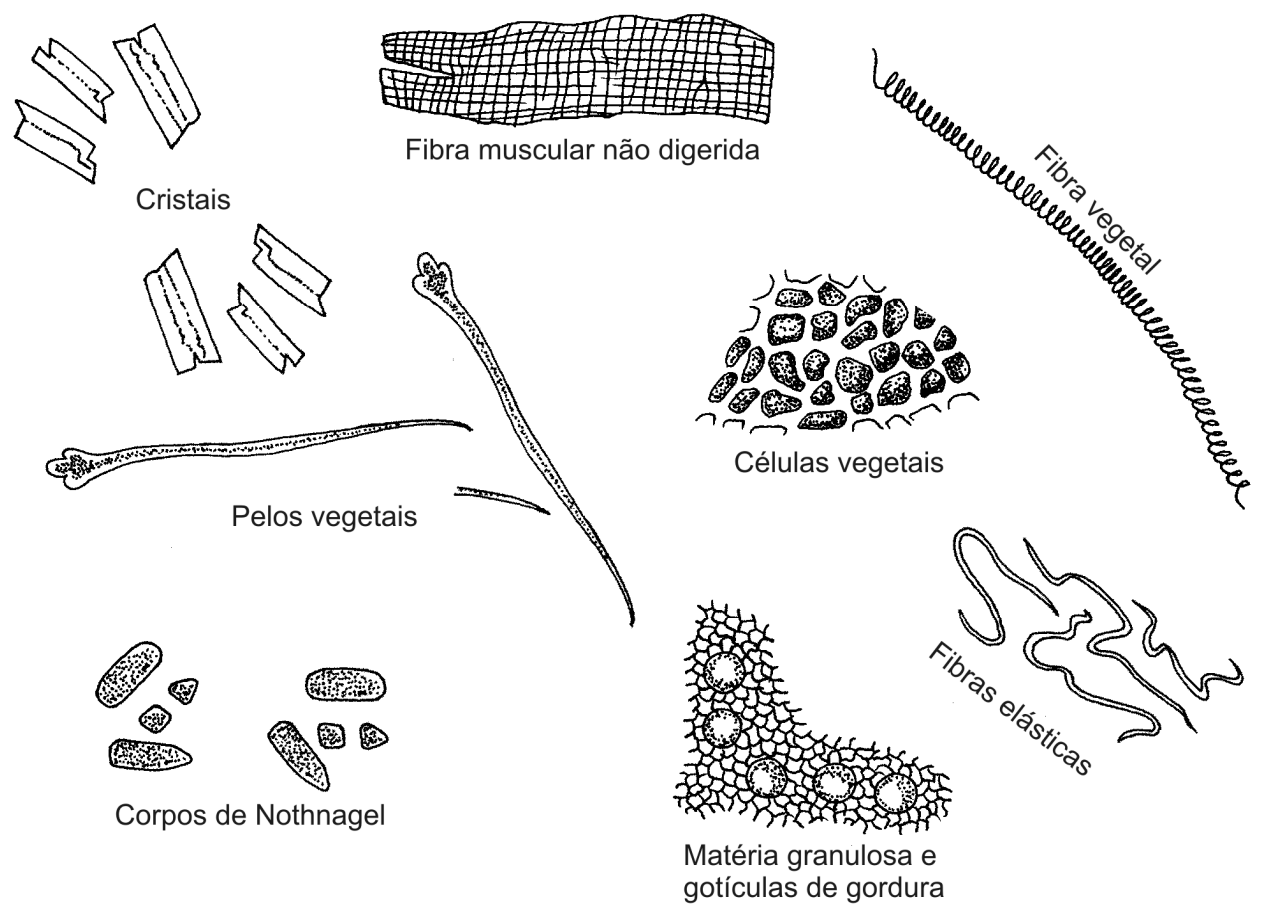

Figura 15 - Elementos microscópicos encontradiços nas fezes.

Svensson \& Wendel $^{173}$ apontam como de maior valor o encontro de folhas de papel $^{174}$ utilizadas pelo criminoso, pela possibilidade, remota, de encontro de fragmentos de impressões digitais.

As manchas de fezes passam a ter maior importância quando mescladas com outras, como sangue, líquido amniótico ou sêmen ${ }^{175}$.

O diagnóstico de espécie, em alguns casos, é difícil. Em geral, devem ser buscadas características físicas, como diâmetro das fezes, consistência, odor e composição da dieta ${ }^{176,177}$. As reações de soroprecipitação mostraram-se ineficazes para as fezes, em razão da grande quantidade de albuminas de origem variada presentes na alimentação.

${ }^{173}$ SVENSSON, Arne; WENDEL, Otto. op. cit., p. 138.

${ }^{174} \mathrm{O}$ papel higiênico comum não permite a pesquisa de impressões, quer pela sua porosidade, quer pela irregularidade de sua superfície. Em alguns raros casos o criminoso pode fazer uso de folhas de papel não absorvente comum e, nessas hipóteses, podem ser encontradas impressões digitais.

${ }^{175} \mathrm{~A}$ presença de manchas fecais com presença de espermatozóides pode indicar a prática de sexo anal com a vítima. Caso possa ser examinado, o legista poderá encontrar restos de matéria fecal no sulco balanoprepucial do suspeito.

${ }^{176}$ Gómez (op. cit., p. 194) recomenda a análise da dieta, pois, segundo ele, nenhum animal tem alimentação tão rica como a do ser humano. Em que pese a posição do renomado mestre, embora isso possa ser tomado como regra para algumas espécies, como bovinos ou eqüinos, o hábito de manter animais de estimação pode fazer com que eles tenham alimentação muito similar senão a mesma do ser humano. Alguns criadores de suínos, da mesma forma, alimentam seus rebanhos com restos de restaurantes, fazendo com que a dieta dos porcos seja igual à humana. 


\subsubsection{Manchas de urina}

A urina é um líquido orgânico, produzido pelos rins e excretado pelas vias urinárias, através da uretra. Um adulto normal excreta em torno de 1 a 1,51 de urina em um período de 24 horas. A coloração varia do transparente, quase água, até o castanho-escuro, como mogno, na dependência da qualidade e da quantidade dos líquidos ingeridos ou de algum quadro patológico existente.

É formada, geralmente, por $95 \%$ de água e $5 \%$ de diversos compostos minerais e orgânicos, cuja natureza e quantidade variam de acordo com a dieta ou produtos químicos administrados.

Como a urina é o meio de excreção de uma grande quantidade de substâncias, notadamente restos do metabolismo, medicamentos e substâncias tóxicas, sua análise assume grande importância médico-legal, particularmente para a toxicologia forense.

As manchas de urina geralmente vêm associadas a outras substâncias como esperma, matéria fecal e mecônio. Quando em tecidos, são reveladas facilmente em razão de sua fluorescência, de amarela à alaranjada, quando expostas à luz ultravioleta (lâmpada de Wood).

A natureza da mancha pode ser confirmada por intermédio de seus compostos majoritários: a uréia, por intermédio da urease e da creatinina, com o reativo de Jaffé. Simonin $^{178}$ indica, ainda, a pesquisa de uréia pelo xantidrol e a de ácido úrico, com o reativo de Folin \& Denis.

Em indivíduos secretores é possível, também, a determinação do grupo sangüíneo pelo sistema $\mathrm{ABO}$ nas manchas de urina, embora a concentração seja muito baixa.

Dependendo da quantidade, também é possível a identificação pelo DNA. A urina possui cerca 1 a 20 nanogramas de DNA disponível por militro ${ }^{179}$.

O quadro abaixo indica alguns valores normais encontrados na urina humana ${ }^{180}$ :

\footnotetext{
${ }^{177}$ Certa feita o suspeito da prática de um homicídio negava ter estado no local do crime. O encontro de aderências de estrume bovino na sola de seu calçado e a comparação com amostras colhidas no local comprovaram que sua versão era inverídica.

${ }^{178}$ SIMONIN, Camille. op. cit., p. 908.

${ }^{179}$ JOBIM, Luiz Fernando; COSTA, Luís Renato; SILVA, Moacyr. op. cit., p. 94.

${ }^{180}$ Apud GORINA, Alfonso Balcells. op. cit.
} 


\begin{tabular}{|l|c|}
\hline Acetona & ausente \\
Ácido úrico & $0,5 \mathrm{a} 1 \mathrm{~g} \mathrm{em} 24 \mathrm{horas}$ \\
Amoníaco & $0,5 \mathrm{~g} \mathrm{em} 24 \mathrm{~h}$ \\
Bilirrubina & ausente normalmente \\
Cálcio & menos de $300 \mathrm{mg} \mathrm{em} 24 \mathrm{~h}$ \\
Cobre & menos de $100 \mu \mathrm{g} \mathrm{em} 24 \mathrm{~h}$ \\
Creatina & ausente ou menos de $0,75 \mathrm{mmol} \mathrm{em} 24 \mathrm{~h}$ \\
Corpos cetônicos & ausentes ou menos de $0,05 \mathrm{~g} \mathrm{em} 24 \mathrm{~h}$ \\
Fósforo & $0,6 \mathrm{a} 1,2 \mathrm{~g} \mathrm{em} 24 \mathrm{~h}$ \\
Glicose & ausente normalmente \\
Nitrogênio total & 5 a $20 \mathrm{~g} \mathrm{em} 24 \mathrm{~h}$ \\
Porfirinas & $50 \mathrm{a} 300 \mu \mathrm{g} \mathrm{em} 24 \mathrm{~h}$ \\
Potássio & $2,5 \mathrm{a} 3,5 \mathrm{~g} \mathrm{em} 24 \mathrm{~h}$ \\
Proteínas & menos de $150 \mathrm{mg} \mathrm{em} 24 \mathrm{~h}$ \\
Serotonina & $31 \mathrm{a} 296 \mu \mathrm{g} \mathrm{em} 24 \mathrm{~h}$ \\
Sódio & $4 \mathrm{a} 6 \mathrm{~g} \mathrm{em} 24 \mathrm{~h}$ \\
Uréia & $20 \mathrm{a} 25 \mathrm{~g} \mathrm{em} 24 \mathrm{~h}$ \\
Urobilinogênio & menos de $4 \mathrm{mg} \mathrm{em} 24 \mathrm{~h}$ \\
\hline
\end{tabular}

\subsubsection{Manchas de vômito}

O encontro de deposições ou manchas de conteúdo gástrico no local pode indicar a composição da última refeição feita pela pessoa que o expeliu e, em alguns casos, levar à outras importantes conclusões.

A quantidade e a constituição dessas manchas ou deposições variam muito na dependência da dieta e do tempo decorrido entre a alimentação e o regurgitamento. A identificação é simples e feita pelo aspecto macroscópico.

O vômito pode ter sido deixado no local, tanto pela vítima, quanto pelo autor. A comparação do material encontrado no local com o conteúdo gástrico da vítima, recolhido durante a necropsia, certamente irá indicar essa procedência. Caso se determine que a êmese foi do autor, será possível orientar uma investigação pelos hábitos alimentares dos suspeitos.

Nos casos de envenenamento (acidental, suicídio ou homicídio ${ }^{181}$ ), o exame das manchas de vômito, assim como o do conteúdo gástrico da vítima, pode auxiliar a identificação da natureza da substância que produziu o óbito ${ }^{182}$.

\footnotetext{
${ }^{181}$ São raros os homicídios com o uso de venenos que precisam ser ingeridos em doses únicas altas ou em frações menores, de forma continuada, durante vários dias. Normalmente esses crimes são cometidos por familiares ou pessoas muito próximas que utilizam substâncias que não irão causar suspeita por sua cor, odor ou sabor (FISHER, Barry A. J. op. cit., p. 475).

${ }^{182} \mathrm{O}$ encontro de materiais de diferentes cores no vômito pode dar indicação do tipo de veneno empregado. Substâncias castanho-escuras, lembrando pó de café, apontam no sentido de envenenamento por alcalóides
} 
A determinação do grupo sangüíneo (sistema $\mathrm{ABO}$ ) a partir do conteúdo gástrico é possível, mesmo depois de muito tempo decorrido ${ }^{183}$.

\subsubsection{Manchas de leite}

O leite é um líquido formado por $88,5 \%$ de água e $11,5 \%$ de gorduras em suspensão (oleína, palmitina, butirina, cofraína, caprina, caprilina, etc.) e solutos variados, entre os quais carboidratos (lactose e cerca de 30 outros açúcares, como galactose, frutose e diversos oligossacarídeos), sais (cloretos, fosfatos, citratos, etc.), aminoácidos essenciais e imunoglobulinas ${ }^{184}$.

As proteínas e os aminoácidos do leite humano são estruturais e qualitativamente diferentes das do leite dos outros animais. Do seu conteúdo protéico, por exemplo, 80\% corresponde à lactoalbumina, enquanto que no leite de vaca essa proporção é representada pela caseína. Ainda em comparação com o leite de vaca, o leite humano contém maior concentração dos aminoácidos essenciais cistina e taurina.

O encontro de manchas produzidas por secreção mamária humana (leite e colostro) normalmente está associado a problemas médico-legais ligados ao parto e ao aborto.

As manchas têm coloração amarelo-acinzentada, mais escura nas bordas. Quando secas, dão ao tecido um aspecto engomado, similar às de esperma.

Os exames químicos de orientação podem ser realizados fazendo-se um macerado da amostra e utilizando-se reativos diversos ${ }^{185}$ :

a) guaiacol - amarelo-alaranjado;

b) hidroquinona - rosa; e

fortes como hidróxido de sódio ou potássio; amareladas sugerem ácido nítrico ou crômico; azulesverdeadas insinuam sulfato de cobre; negras fazem presumir ácido sulfúrico e castanho-esverdeadas o ácido hidroclorídrico. Vômitos de odor penetrante indicam envenenamento por amoníaco ou ácido acético (FISHER, Barry A. J. op. cit., p. 475).

${ }^{183}$ Svensson \& Wendel, reportando-se aos trabalhos de Andersen, afirmam que a identificação dos grupos sangüíneos pode ser feita em resíduos encontrados seis meses após o vômito (SVENSSON, Arne; WENDEL, Otto. op. cit., p. 138).

${ }^{184}$ GUYTON, Arthur C.; HALL, John E. Tratado de fisiologia médica. 10. ed. Rio de Janeiro: Guanabara Koogan, 2002. p. 894.

${ }^{185}$ DOREA, Luiz Eduardo; STUNVOLL, Victor Paulo; QUINTELA, Victor. op. cit., p. 82. 
c) pirocatequina - amarelo-escuro.

Gómez ${ }^{186}$ aponta a análise microscópica como preferencial para o diagnóstico de certeza. O leite apresenta glóbulos de gordura, arredondados, refringentes e com diâmetro entre 1 e $10 \mu^{187}$. O fundo da preparação é ocupado por numerosos grânulos de proteína e de fostato de cálcio. Às vezes podem ser observadas células epiteliais prismáticas dos canais excretores da glândula mamária (dutos galactóforos).

O exame específico para a espécie humana pode, teoricamente, ser feito por reações de soroprecipitação semelhantes às preconizadas para o sangue humano, embora prejudicadas pelo aspecto opaco do leite.

A determinação do grupo sangüíneo (sistema $\mathrm{ABO}$ ) a partir do leite é também possível.

\subsubsection{Manchas de colostro}

O colostro ${ }^{188}$ é um líquido amarelado, secretado pelas glândulas mamárias, alguns dias antes e depois do parto, rico em anticorpos e leucócitos e essencial para a saúde do neonato.

As manchas de colostro são similares às de leite, mas de coloração mais amarelada.

O exame de certeza é o microscópico. O colostro apresenta glóbulos de gordura em maior número e de maior diâmetro que o leite comum. Algumas gotas de gordura apresentam-se agrupadas por uma substância albuminóide viscosa - são os corpos granulosos de Donne ou corpúsculos do colostro de Henle. Esses corpúsculos, muito abundantes no colostro, desaparecem quase que completamente no leite normal, cerca de oito dias após o parto ${ }^{189}$.

A determinação do grupo sangüíneo (sistema $\mathrm{ABO}$ ), assim como no leite, é também possível.

\footnotetext{
${ }^{186}$ LÓPEZ GÓMEZ, Leopoldo. op. cit., p. 189.

${ }^{187}$ Maiores e em maior número que os observados no colostro.

${ }^{188}$ Denomina-se neógala ao primeiro leite secretado pelas glândulas mamárias após o colostro.

${ }^{189}$ LÓPEZ GÓMEZ, Leopoldo. op. cit., p. 189.
} 


\subsubsection{Manchas de muco nasal}

As manchas de muco nasal são brancas, amarelas ou acinzentadas, similares às de esperma e podem vir acompanhadas de pós de natureza diversa aspirados pelo nariz. Quando expostas à luz ultravioleta (lâmpada de Wood), produzem coloração azul-claro. O exame microscópico revela muco, células prismáticas da mucosa nasal, células epiteliais, vibrissas $^{190}$, microorganismos e partículas de carbono.

Em indivíduos secretantes, à semelhança do que ocorre com a saliva, é possível a determinação de grupos sangüíneos.

O muco nasal, dependendo da quantidade, permite a identificação pelo DNA.

\subsubsection{Manchas de secreções bronquiais}

Também denominadas de escarro, catarro ou esputo, as secreções bronquiais normalmente vêm mescladas com muco nasal ou saliva, dependendo da maneira como ganham o exterior do organismo (pela boca ou pelo nariz), podendo ainda ser acompanhadas de sangue, pus ou outras secreções orgânicas.

O escarro pode apresentar coloração e odor variados. Nos organismos sadios a secreção é geralmente inodora e incolor (esbranquiçada), podendo as manchas, em alguns casos, ser confundidas com as de esperma.

O odor fétido e penetrante pode indicar alguma infecção pulmonar, mas dificilmente poderá servir como meio de diagnóstico porque a diferença de cheiro entre uma e outra afecção é muito sutil.

A quantidade e a coloração são mais características, podendo, em alguns casos, apontar enfermidades do aparelho respiratório e constituir mais um elemento de auxílio na identificação do autor do fato.

Ao exame macroscópico o catarro pode apresentar uma constituição homogênea de consistência serosa, mucosa, purulenta ou hemática. Geralmente, entretanto, mostra-se na forma mista, ou seja: sero-hemático, mucopurulento, etc.

\footnotetext{
${ }^{190}$ Pêlos do nariz.
} 
Ao exame microscópico, o esputo revela células da mucosa brônquica, células prismáticas ciliadas, células pavimentosas ou escamosas da boca e laringe, células alveolares, leucócitos, eritrócitos, microorganismos, cristais de Charcot-Leyden e outros.

Através do escarro é possível a determinação do grupo sangüíneo (sistema $\mathrm{ABO}$ ) e, na dependência da quantidade e citologia encontrada, a identificação pelo DNA.

\subsubsection{Manchas de secreções uretrais}

As secreções uretrais apresentam-se sob a forma de manchas acinzentadas ou amareladas de pequeno volume. Podem ser encontradas em locais relacionados com crimes sexuais.

O diagnóstico é feito pelo exame microscópico e geralmente pela identificação de gonococos. Podem também ser eventualmente encontrados cristais de Florence (cristais de iodeto de colina), mas em número menor que os observados no esperma.

Dependendo da quantidade e da preservação da amostra é possível a identificação pelo DNA.

\subsubsection{Manchas de secreções vaginais}

São manchas amareladas e extensas, de contornos sinuosos e composição variável, podendo vir inclusive contaminadas por sangue, proveniente ou não do catamênio $^{191}$, e de esperma.

Da mesma forma que em relação às secreções uretrais, têm grande importância nos crimes de cunho sexual e o seu diagnóstico deve ser feito pela análise microscópica.

Dependendo da quantidade e da preservação da amostra, também é possível a identificação pelo DNA.

${ }^{191}$ Menstruação. 


\subsubsection{Manchas de substâncias graxas}

São encontradas sob a forma de manchas grandes, brancas e de aspecto graxo, com estrias correspondentes às pregas do corpo. Têm pouco interesse médico-legal, com exceção das manchas de unto sebáceo.

O diagnóstico deve ser feito pela análise microscópica.

\subsubsection{Manchas de unto sebáceo}

As manchas de unto sebáceo relacionam-se, quase sempre, com casos de aborto, partos clandestinos ou infanticídios e comumente vêm acompanhadas se sangue, líquido amniótico, mecônio e matéria fecal.

O unto sebáceo é uma substância esbranquiçada e untuosa que recobre o corpo do feto, sendo especialmente abundante nas pregas inguinais e axilas. É composto por células de descamação da epiderme, aglutinadas por uma substância oleosa formada por gorduras neutras como a lanolina, ácidos graxos (oléico e palmítico) e sabões diversos ${ }^{192}$.

As manchas são de grandes dimensões, lembrando o contorno do feto. Têm aspecto esbranquiçado e intensidade variada, na dependência da parte do corpo que esteve em contato com o suporte.

O exame microscópico (figura 16) é o único que permite uma identificação precisa. São observadas células epidérmicas sem núcleo, oriundas da camada córnea descamada (A), alguns pêlos da lanugem fetal (B), raros cristais de ácidos graxos, que dissolvem em éter e colorem em negro pelo ácido ósmico $(\mathrm{C})$ e traços de material sebáceo (D).

${ }^{192}$ Apud LÓPEZ GÓMEZ, Leopoldo. op. cit., p. 185. 


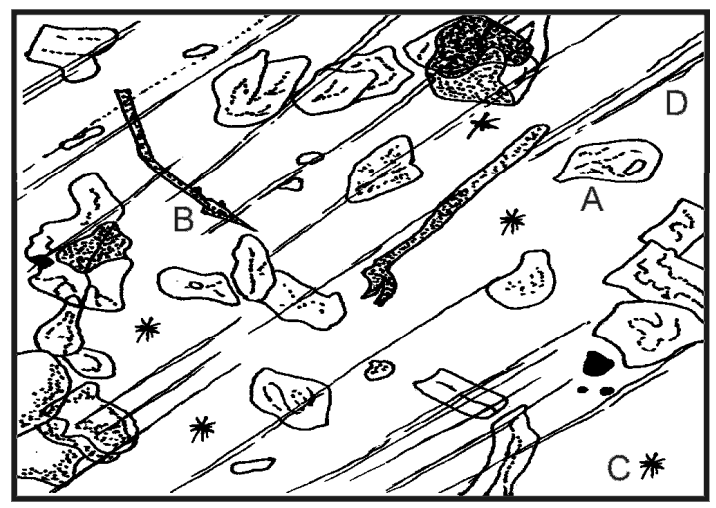

Figura 16 - Elementos microscópicos encontradiços no unto sebáceo.

Dependendo da quantidade, o encontro de sangue contaminante, se não pertencente ao feto, pode permitir a identificação da mãe pelo DNA.

\subsubsection{Manchas de secreção purulenta}

O pus é um líquido espesso, opaco, de coloração amarelada e consistência serosa, que se forma no local de um ferimento infeccionado ou de um processo infeccioso. É composto, basicamente, por glóbulos brancos, alterados ou não, células de tecidos vizinhos ao ponto de supuração e por microorganismos vivos ou mortos.

Nos locais de crime dificilmente são encontradas isoladas, mas comumente mescladas com sangue ou outros líquidos orgânicos.

O diagnóstico é microscópico, pela citologia do achado, e relativamente simples.

Dependendo da quantidade da secreção, é possível a identificação pelo DNA.

\subsubsection{Manchas de líquido amniótico}

O líquido amniótico é a substância contida na cavidade amniótica e tem por função precípua a proteção do feto contra choques e dessecação. $\mathrm{O}$ encontro de manchas desse líquido está sempre relacionado com casos de aborto, partos clandestinos e infanticídio. 
O líquido amniótico é muito fluido, de coloração amarelo-esverdeada, algumas vezes claro e límpido, outras vezes turvo, sobretudo no final da gestação. De odor desagradável e característico, é constituído por $96 \%$ de água e $4 \%$ de sais, mucina, gorduras, uréia, células diversas e pêlos da lanugem fetal ${ }^{193}$.

As manchas apresentam dimensão relativamente grande e sua coloração oscila entre a amarela e a esverdeada.

O exame microscópico ${ }^{194}$ (figura 17) revela pouquíssimos elementos figurados. Células superficiais do epitélio vaginal (A), conjuntos de células vaginais de núcleo grande (B), colesterol (C), hemácias (D), células epidérmicas da camada córnea (E), pêlos da lanugem fetal $(\mathrm{F})$ e fibras têxteis provenientes do macerado do suporte da mancha.

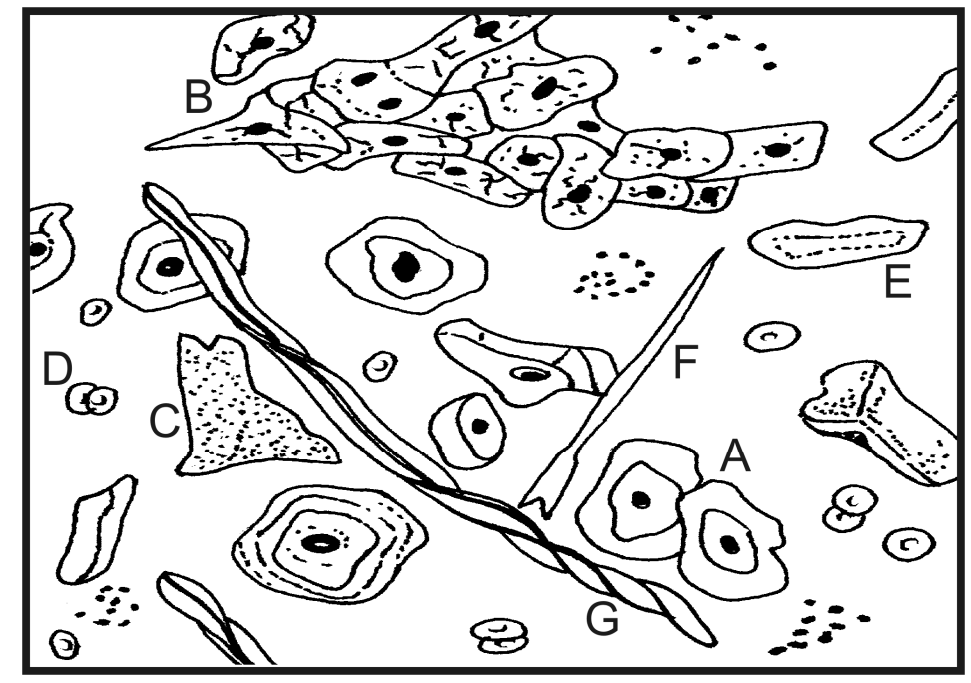

Figura 17 - Elementos microscópicos encontradiços no líquido amniótico.

Sendo possível a coleta de quantidade razoável do líquido amniótico fresco ${ }^{195}$, alguns exames laboratoriais podem ser tentados, como, por exemplo, o exame citogênico $^{196}$, a análise bioquímica ${ }^{197}$, a determinação do sexo ${ }^{198}$ e do grupo sangüíneo ${ }^{199}$

\footnotetext{
${ }^{193}$ LÓPEZ GÓMEZ, Leopoldo. op. cit., p. 187.

${ }^{194}$ Apud SIMONIN, Camille. op. cit., p. 271.

${ }^{195}$ Oriundo de uma gestação que atingiu ao menos a $15^{\mathrm{a}}$ semana.

${ }^{196} \mathrm{Com}$ cerca de $1 \mathrm{ml}$ de líquido amniótico é possível estabelecer, em 10 a 15 dias, o cariótipo do feto e eventuais aberrações cromossômicas.

${ }^{197}$ Dosagem da alfafetoproteína, da acetilcolinesterase, de fosfolipídios, de estriol e outras substâncias que podem indicar alterações do feto.

${ }^{198}$ Pela determinação do cariótipo ou pelo exame do corpúsculo de Barr ou cromatina sexual (presentes apenas nas fêmeas dos mamíferos).

${ }^{199}$ Pelo estudo citológico do líquido amniótico (Apud GORINA, Alfonso Balcells. op. cit.).
} 
do feto, realizados como rotina a partir da punção amniótica. Além desses, o líquido amniótico permite a identificação pelo $\mathrm{DNA}^{200}$.

\subsubsection{Produtos da gestação}

Nos locais relacionados com aborto, partos clandestinos ou infanticídios, além de manchas de sangue, mecônio, fezes, leite, colostro, unto sebáceo e líquido amniótico, podem ser encontrados os chamados anexos fetais (placenta e cordão umbilical), o próprio embrião $o^{201}$ ou o feto ${ }^{202}$ ou ainda suas partes.

A placenta é o órgão vascular que nos mamíferos eutérios ${ }^{203}$, une o feto à parede do útero materno através do cordão umbilical, permitindo a passagem de materiais nutritivos e oxigênio para o sangue fetal e a eliminação de dióxido de carbono e resíduos nitrogenados. Na espécie humana é plano, arredondado e de consistência esponjosa. Além das funções de proteção e nutrição do feto, é uma glândula de secreção interna, produzindo diversos hormônios ${ }^{204}$.

O peso e o diâmetro da placenta variam de acordo com a fase da gestação, de acordo com o quadro abaixo ${ }^{205}$ :

\begin{tabular}{|c|c|c|}
\hline Semanas & Peso em gramas & Diâmetro em centímetros \\
\hline 12 & 30 a 50 & 6,0 \\
16 & 80 a 100 & 7,5 a 8,5 \\
20 & 180 a 200 & 11,5 a 12,0 \\
24 & 250 a 275 & 12,5 a 13,0 \\
28 & 300 a 320 & 13,5 a 14,0 \\
32 & 370 a 400 & 15,5 a 17,0 \\
36 & 480 a 500 & 17,0 a 18,0 \\
40 & 50 a 600 & 18,0 a 20,0 \\
\hline
\end{tabular}

\footnotetext{
${ }^{200}$ O líquido amniótico possui 65nanogramas/ml de DNA disponível (JOBIM, Luiz Fernando; CosTA, Luís Renato; SiLva, Moacyr. op. cit., p. 94).

${ }^{201}$ Ser humano durante as oito primeiras semanas de seu desenvolvimento extra-uterino (proveta) ou intrauterino (gestação normal).

${ }^{202}$ Ser humano em desenvolvimento após as oito primeiras semanas.

${ }^{203}$ Eutérios são os mamíferos placentários, que se contrapõem aos metatérios ou marsupiais, que nascem em um estágio muito primitivo de desenvolvimento e precisam completar seu crescimento em uma bolsa externa do corpo da mãe (cangurus e coalas).

${ }^{204}$ Gonadotrofina coriônica, estradiol e progesterona.

${ }^{205}$ Apud ZACHARIAS, Manif; ZACHARIAS, Elias. Dicionário de medicina Legal. 2 ed., rev. e ampl. Curitiba: Ed. Universitária Champagnat, 1991. p. 379.
} 
Todos esses achados permitem a identificação pelo DNA, razão pela qual precisam ser recolhidos e preservados para futura análise.

\subsubsection{Peças de vestuário e acessórios}

As peças de vestuário e seus acessórios ou anexos ${ }^{206}$, encontrados nos locais submetidos ao exame pericial ${ }^{207}$ ou com ele relacionados, são de grande importância médico-legal e criminalística, devendo ser minuciosamente analisados e preservados.

De uma maneira geral, o exame das vestes interessa:

a) pelo tipo de vestuário;

b) pelo local e modo em que foram encontradas as peças;

c) pela pessoa que estava vestindo as roupas ou acessórios;

d) pelo estado de integridade, alinho ou desalinho em que se apresentam;

e) pela presença de manchas ou aderências de interesse médico-legal ou criminalístico; e

f) pelos objetos que pode conter e que apresentam relação com o fato.

\section{Análise das vestes pelo tipo}

No caso de vítimas não identificadas, o tipo de roupa utilizado, seu estado de conservação, a presença ou não de peças de griffe e de acessórios de boa qualidade, como cintos de couro, jóias, calçados e bolsas de preço elevado, são sinais de que a pessoa pertencia a uma classe social elevada.

O uso de paletó e gravata aponta para uma profissão de maior representação e formalidade, como advogados, representantes comerciais e algumas espécies de vendedores. As roupas brancas podem levar à conclusão de que se trata de pessoal ligado à área de saúde (médicos, dentistas, enfermeiros, etc.). Aventais, uniformes e roupas de brim permitem inferir outras profissões.

\footnotetext{
${ }^{206}$ Calçados diversos (sapatos, botas, sandálias, chinelos, etc.), cintos, suspensórios, lenços, gravatas, jóias (anéis, colares, pulseiras, pingentes, etc.), bolsas, carteiras, pochettes e outros.

${ }^{207}$ Ver também o item 2.6.4.8: "Marcas deixadas por peças de vestuário".
} 
Também os anexos podem fornecer importantes dados ao perito. As alianças sugerem o estado civil, os anéis de formatura a profissão, certos tipos de adereços, como pulseiras com nomes ou signos, pistas para a determinação da identidade.

A aparente ausência de uma peça do conjunto, como a marca, em um dos dedos, de um anel inexistente, é circunstância que deve ser informada para a autoridade policial a fim de que a busca desse elemento possa ser incluída nas investigações.

\section{Análise das vestes quanto ao local em que foram encontradas e a pessoa que as} usava

Quanto ao local em que foram encontrados e a pessoa que as usava, as peças de vestuário e acessórios podem ser encontrados nas seguintes situações:

Peças de vestuário e acessórios $\left\{\begin{array}{l}\text { pertencentes à vítima } \\ \begin{array}{l}\text { encontrados vestindo o corpo da vítima } \\ \text { encontrados no local do fato } \\ \text { encontrados vestindo terceira pessoa } \\ \text { encontrados em local relacionado }\end{array} \\ \text { pertencentes à terceira pessoa }\left\{\begin{array}{l}\text { encontrados vestindo o corpo da vítima } \\ \text { encontrados no local do fato } \\ \text { encontrados em local relacionado }\end{array}\right.\end{array}\right.$

Nos crimes envolvendo o evento morte, não raro podem ser encontradas peças de vestuário da vítima na casa do autor ou mesmo sendo por ele utilizadas. Tais encontros são provas irrefutáveis de autoria, principalmente se a pessoa nega relação com a vítima ou mesmo ter estado no local do delito.

Também é possível que o autor deixe no local, por esquecimento ou acidentalmente, peças de seu vestuário, como blusas e lenços, ou mesmo parte de suas roupas, como botões, adereços, contas de um colar, pedaços rasgados de tecido e outros.

Mais raramente o perito poderá verificar vestes de terceiros envolvendo a vítima. Isso é relativamente freqüente nos casos de aborto ou infanticídio, quando o autor utiliza peças de seu próprio vestuário para ocultar, e depois transportar o feto ou o recém-nascido para livrar-se do corpo.

Todas as peças devem ser fotografadas onde se encontrem, etiquetadas, recolhidas de forma conveniente e preservadas para futuros reconhecimentos, análises e comparações. 
Fisher $^{208}$ recomenda que, em sendo possível, o suspeito deve despir-se sobre uma folha limpa de papel de embrulho para evitar que pequenas partículas de interesse possam ser perdidas. O mesmo autor aconselha embalar as peças de roupa em sacos de papel e não de plástico, pela possibilidade de descoloração do tecido por ação de fungos.

No geral, aconselha-se que o exame das peças de vestuário seja feito sobre uma ampla folha de papel branco, absolutamente livre de resíduos, e com auxílio de uma lente de aumento ${ }^{209}$.

É especialmente importante que a recolha das vestes do suspeito seja feita longe de qualquer possível fonte de contaminação ligada ao local do crime, com o cuidado de não sacudir as peças ao colocá-las nas embalagens apropriadas, de modo a evitar a inutilização ou a perda de eventuais provas.

Os principais vestígios encontrados nas vestes são sempre recolhidos da vítima ou do suspeito logo após a prática do crime. A demora na coleta pode fazer com que pequenos itens como fios de cabelo ou fibras estranhas ao tecido original sejam perdidos em prejuízo da investigação.

Análise das vestes pelo estado de integridade, alinho ou desalinho em que se apresentam

Uma das primeiras preocupações do perito que examina local em que ocorreu evento morte, e antes de tocar no corpo da vítima, é a análise minuciosa de sua vestimenta. Dependendo da natureza jurídica do evento (acidente, homicídio ou suicídio), deve-se esperar que as vestes assumam uma configuração lógica, que, uma vez quebrada, pode fornecer importantes indícios para o deslinde da ocorrência.

Nos crimes patrimoniais a vítima comumente é despojada de seus objetos e pertences pessoais, mas o perito deve tomar cuidado para não basear suas conclusões apenas nesse elemento, porque é perfeitamente possível que esteja diante de uma simulação que busca ocultar a verdadeira natureza da ocorrência, ou seja, homicídio.

É possível que a autoridade policial ou seus agentes tenham prejudicado o local, retirando dali elementos importantes para a perícia. Isso pode ocorrer ou por evidente

\footnotetext{
${ }^{208}$ FISHER, Barry A. J. op. cit., p. 165.

${ }^{209}$ SVENSSON, Arne; WENDEL, Otto. op. cit., p. 150.
} 
despreparo ou em razão de socorro prestado à vítima. Em ambas as situações o perito deve ser informado das inovações para não ser induzido em erro ${ }^{210}$.

Nos suicídios ${ }^{211}$ as vestes costumam estar normalmente dispostas, sem sinais de violência, enquanto nos homicídios, se houve resistência por parte da vítima, são freqüentes os desalinhos, os rasgos e a perda de botões.

Sevensson \& Wendel $^{212}$ lembram que nos casos de violência com instrumentos contundentes, em certas condições é possível encontrar nas vestes impressões da arma utilizada. Um capacete, por exemplo, pode evidenciar claramente a forma de um golpe desferido por martelo ou outra ferramenta.

A danificação das fibras do tecido em correspondência com os ferimentos observados no corpo pode revelar que uma contusão foi originada por um chute ou atropelamento. Além disso, as impressões nas vestes podem vir acompanhadas de sujidades, poeira ou outros materiais que estavam aderidos ao instrumento e fornecer importantes pistas para a investigação.

As soluções de continuidade observadas nas roupas podem, ainda, servir como base para a reconstituição do evento, particularmente nos casos de agressão por instrumentos perfurantes ou perfurocortantes ${ }^{213}$. Como é sabido, a vítima, ao ser agredida por objetos dessa natureza, costuma defender-se, levantando os braços e colocando as mãos como anteparo aos golpes, fazendo com que as perfurações constatadas nas roupas fiquem um pouco deslocadas em relação aos ferimentos correspondentes e, mais tarde, sirvam como elemento de determinação da dinâmica do evento.

Quando a lesão tiver sido produzida por instrumento perfurocortante, a medida da lesão observada na roupa é mais precisa para a identificação do instrumento que a da pele, devido à elasticidade desta ${ }^{214}$.

\footnotetext{
${ }^{210}$ Um caso sempre lembrado no Instituto de Criminalística de São Paulo conta a história de um perito que, certa feita, deparou-se com um local em que havia o corpo de uma pessoa morta com um ferimento perfurocontuso na cabeça e os bolsos de suas vestes revirados para fora, quadro que fez com que o experto concluísse, inicialmente, pela ocorrência de latrocínio. Posteriormente, em contato com a autoridade policial, soube tratar-se de um suicídio, onde a arma, o bilhete e todos os pertences pessoais haviam sido recolhidos pelos policiais antes da chegada da perícia.

${ }^{211}$ Com exceção, por óbvio, dos suicídios cometidos mediante emprego de explosivos, por precipitação ou por atropelamento.

${ }^{212}$ SVENSSON, Arne; WENDEL, Otto. op. cit., p. 335.

${ }^{213}$ Punhais, facas e similares.

${ }^{214}$ KEHDY, Carlos. op. cit., p. 201.
} 


\section{Análise das vestes pela presença de manchas ou aderências de interesse}

As roupas são excelentes fontes de vestígios. Substâncias microscópicas e macroscópicas podem aderir ao vestuário por atritamento, embebição, ação de eletricidade estática ou mesmo ficar presa nas dobras do tecido por pura ação mecânica ou pela gravidade.

Com relação às manchas orgânicas, reportamo-nos aos itens precedentes, lembrando que todas elas podem ter como suporte peças diversas de vestuário. Antes de proceder às análises químicas e bioquímicas dessas substâncias, elas devem ser fotografadas e analisadas no local e da forma em que se encontram.

A orientação das manchas de sangue, pela ação da gravidade, é de excepcional importância no que toca à determinação da posição do corpo e da dinâmica do evento, razão pela qual sua aparência, quando da chegada da equipe técnica, precisa ser analisada e preservada por meio de fotografia e desenho.

Da mesma forma manchas inorgânicas ${ }^{215}$ como ceras, tintas, ferrugem, solventes graxas e outras precisam ser devidamente identificadas, documentadas, recolhidas e preservadas para ulteriores exames.

Entre os resíduos que podem ser encontrados nas vestes, chamam atenção os provenientes do disparo de armas de fogo, as poeiras e cinzas e outros materiais.

\section{Resíduos provenientes do disparo de arma de fogo}

Achado freqüente nas vestes são as aderências, por vezes imperceptíveis, de resíduos provenientes do disparo de armas de fogo. A preservação e estudo das vestes nos casos de agressão por agentes dessa natureza é crucial, particularmente no que toca à determinação da natureza do instrumento causador da lesão e da distância do disparo ${ }^{216}$.

É possível que, em razão de socorro prestado à vítima, as roupas sejam retiradas sem cuidado e até mesmo cortadas nos locais em que houve perfuração por projétil.

\footnotetext{
${ }^{215}$ A expressão "manchas inorgânicas" não está sendo utilizada apenas no sentido técnico de substâncias minerais, mas englobando tudo aquilo que não seja decorrente de líquidos ou secreções fisiológicas de origem humana ou de animais.

${ }^{216}$ Não raro, os resíduos comprovadores da pequena distância do disparo depositam-se apenas sobre as vestes, principalmente se forem peças fechadas e de tecidos grossos ou de muitas camadas, como jaquetas ou paletós. Nesses casos, se as peças forem retiradas antes da chegada do corpo ao Instituto Médico-Legal, o legista pode ser induzido a erro, atestando a existência de um ferimento produzido por disparo realizado à longa distância.
} 
Mesmo assim, essas peças devem ser recolhidas e preservadas, informando-se o perito do ocorrido, para que a circunstância do socorro possa ser considerada quando dos exames laboratoriais.

\section{Poeiras e cinzas}

Poeira é a terra seca ou qualquer substância reduzida a partículas muito finas, capazes de pairar no ar, ainda que por curto espaço de tempo, depositando-se sobre os móveis, vestes e objetos do local.

Segundo Carlos Kehdy ${ }^{217}$, as poeiras dividem-se em:

a) poeiras profissionais; $\mathrm{e}$

b) outras poeiras.

As poeiras profissionais são aquelas encontradas no ambiente de trabalho de determinados profissionais, como marceneiros, carpinteiros, serralheiros, gesseiros, pedreiros e outros.

O renomado mestre ensina que o encontro dessas poeiras nas roupas do suspeito ou no local do fato, deixadas pelo autor do fato, nem sempre permite a conclusão de que ele exerce a profissão correspondente, mas sim que teve qualquer ligação imediata com ambiente dessa natureza.

Outras poeiras como pó caseiro antigo, caliça, terra fina e outras, poderão fornecer indicações a respeito da forma como o suspeito entrou no local, do ambiente em que trabalha ou dos lugares que freqüenta habitualmente.

Cinzas são os resíduos decorrentes da combustão de certas substâncias (madeira, papel, folhas, etc.). Embora tenham importância criminalística, no caso específico das vestes, quando eventualmente encontradas nas roupas do suspeito, terão importância se puderem ser comparadas com material encontrado no local ou vice-versa.

O exame laboratorial das cinzas pode variar dependendo da substância queimada. Algumas vezes elas podem ser analisadas quimicamente, outras microscópica ou

\footnotetext{
${ }^{217}$ KEHDY, Carlos. op. cit., p. 199.
} 
espectroscopicamente. No entanto, ainda que possa haver comparação, a origem do material combusto dificilmente poderá ser determinada ${ }^{218}$.

\section{Outros materiais}

Seria praticamente impossível enumerar todos os materiais e resíduos que podem impregnar as vestes da vítima ou de pessoa suspeita. Lascas de madeira, fibras têxteis, aderências vegetais (folhas, sementes, pólen, etc.), areia, terra, fragmentos de vidro, aparas de papel, restos de alimentos, marcas de cosméticos, pêlos e cabelos são apenas alguns exemplos possíveis.

Todos os vestígios, por mais insignificantes que possam parecer, devem ser anotados, fotografados da forma como encontrados, identificados e preservados para questionamentos ou exames futuros.

\section{Fragmentos de tecidos}

Fragmentos de tecido encontrados no local do fato ou em local relacionado ${ }^{219}$, e que possam ser identificados como provenientes de alguma peça de vestuário, devem ser identificados, fotografados e preservados. Esses fragmentos assumem relevância quando permitirem a comparação com as roupas de eventual suspeito ou as vestes da vítima, constituindo prova concludente, especialmente nos casos em que o possível autor nega ter estado no palco dos acontecimentos ou ter mantido qualquer contato com a vítima.

Esses fragmentos de tecido são comumente encontrados em atropelamentos, presos às ferragens do veículo atropelante, e servem como demonstração cabal de autoria, ainda que o veículo não tenha experimentado danos significativos ou não apresente outras evidências, como sangue ou retalhos de pele.

Às vezes é possível encontrar pequenos fragmentos de tecido aderidos aos projéteis de arma de fogo (figura 18) e, nesses casos, é necessário fazer um estudo comparativo para saber se as fibras são oriundas das roupas trajadas pela vítima ou de terceira pessoa.

\footnotetext{
${ }^{218}$ FISHER, Barry A. J. op. cit., p. 190.

${ }^{219}$ Podem ser encontrados, por exemplo, fragmentos de vestes da vítima na casa ou mesmo aderidos às roupas do suspeito.
} 


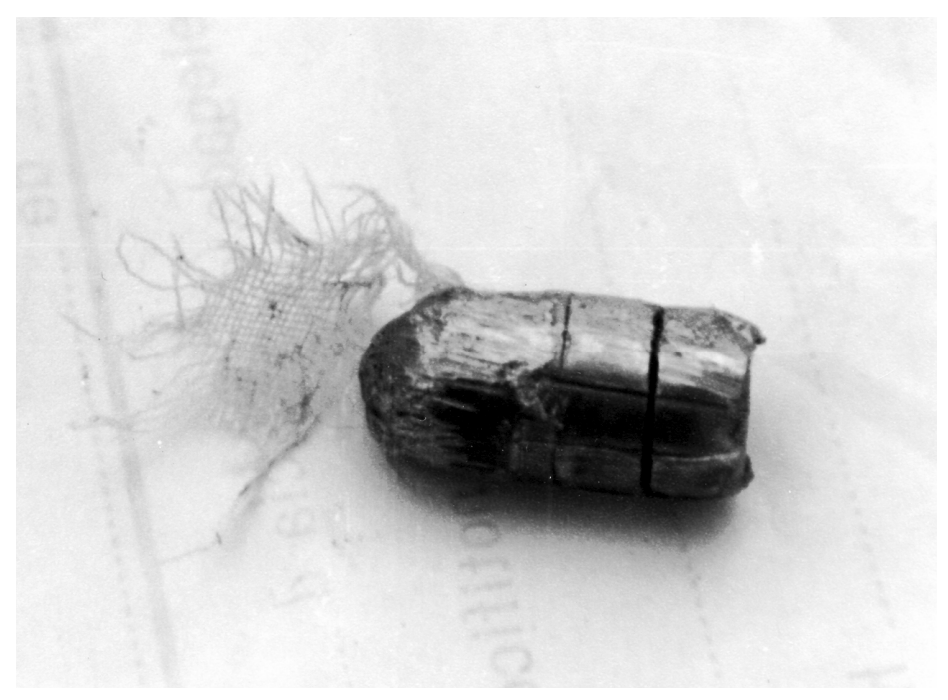

Figura 18 - Fragmento de tecido aderido ao projétil.

Botões, seus fragmentos e as linhas utilizadas para a sua fixação são também elementos passíveis de comparação e identificação.

\section{Calçados diversos}

Sapatos e outros tipos de calçados são valiosos itens de interesse. Podem reter poeira, terra, caliça, vidro ${ }^{220}$, vegetação, sangue, e outros materiais. Quando apreendidos, assim como as demais peças de vestuário, devem ser embalados individualmente de modo a evitar contaminações.

Um cuidado particular precisa ser tomado quando da embalagem de sapatos com aderências de torrões de terra seca. A análise do solo pode ser de grande valor para a determinação do caminho percorrido pelo agente, e o exame pode ficar prejudicado se o torrão se desfizer durante o transporte.

Análise das vestes pelos objetos que podem conter e que apresentam relação com o fato

Particularmente nos casos em que a vítima não foi ainda identificada, o exame dos objetos pessoais e pertences é de capital importância para a perícia e para as investigações.

\footnotetext{
${ }^{220}$ Fisher relata o caso do autor de um furto preso porque encontraram na fissura da sola de seu sapato um fragmento de vidro aderido (FISHER, Barry A. J. op. cit., p. 168).
} 
Entretanto, o técnico deve ter a cautela de manusear as roupas à procura desses elementos somente depois de ter feito todo um minucioso exame em busca dos demais vestígios mencionados. A revista por documentos pessoais deve ser sempre a última providência do perito.

Da mesma forma, cabe à autoridade policial, por expressa disposição legal (arts. $6^{\circ}$, I, e 169, caput, do CPP) a preservação do local. Lamentavelmente, na prática, o que se vê é exatamente o oposto. Aqueles que deveriam velar pela integridade das provas são os primeiros a prejudicá-las.

Além de documentos, as vestes podem ocultar outros elementos, como o bilhete do suicida, agendas, em papel ou eletrônicas, notepads, armas, munições, pertences de terceiros, numerário nacional e estrangeiro e outros.

Tudo deve ser fotografado, relacionado, etiquetado e preservado. No caso específico de jóias e valores, é conveniente que a arrecadação seja feita na presença de pessoa da família. Como norma, tudo que for arrecadado pelo perito deve ser encaminhado para a autoridade policial mediante auto de exibição e apreensão (art. $6^{\circ}$, II, do CPP $)^{221}$.

É evidente que as hipóteses mencionadas têm objetivo apenas de ilustração. Cada caso apresenta suas peculiaridades que devem ser cuidadosamente analisadas e ponderadas pelo perito antes de lançar suas conclusões.

\subsubsection{4. Órteses e próteses}

Próteses são peças ou aparelhos utilizados para substituir partes do corpo amputadas ou malformadas. Órteses são dispositivos provisórios de uso externo que têm como objetivo proporcionar melhora funcional (correção ou complementação) de membros ou órgãos do corpo ${ }^{222}$.

Além das próteses e órteses, temos ainda os materiais auxiliares, que complementam e auxiliam na recuperação ou desempenho de função anatômica e funcional, como, por exemplo, muletas, cadeiras de rodas, andadeiras, etc.

\footnotetext{
${ }^{221}$ Excepcionalmente, e não guardando qualquer relação com o fato em estudo, os bens podem ser entregues para familiares mediante recibo e testemunhas.

${ }^{222} \mathrm{O}$ aparelho dentário ortodôntico, por exemplo, é uma órtese, pois tem por objetivo corrigir a deformidade da arcada dentária, enquanto a dentadura ou o implante dentário são próteses, porque substituem os dentes.
} 
Todos esses materiais, quando eventualmente encontrados no local, precisam ser fotografados, identificados e preservados, quer pertençam à vítima, quer à terceira pessoa.

Quando pertencentes à vítima, a presença desses aparelhos pode indicar uma deficiência física caracterizadora de circunstância agravante em determinados crimes.

\subsubsection{Escritos e desenhos}

Também é possível encontrar nos locais escritos e desenhos deixados pela vítima ou por terceiros.

Cartas recebidas ou enviadas e que possam indicar os relacionamentos da vítima com outras pessoas, endereços, telefones, mapas de localização que apontem lugares em que ela esteve ou precisava comparecer, são apenas alguns exemplos daquilo que deve despertar o interesse do perito de local.

Nos suicídios são comuns as cartas e disposições de última vontade. Embora existam pouquíssimos trabalhos dedicados ao estudo dessas mensagens de despedida, a experiência mostra que são textos objetivos, não muito longos, e que apresentam uma progressão lógica de começo, meio e fim, em que o protagonista explicita suas razões e transmite algumas determinações que considera fundamentais, quer a respeito da disposição de seus bens, quer em relação às providências de seu funeral.

Como assinala Maria Luiza Dias ${ }^{223}$ :

"Uma vez que o indivíduo nunca está descompromissado com o meio social e com os vínculos que nele estabelece (embora ele próprio acredite que sim), $\mathrm{o}$ ato suicida está sempre voltado para o mundo em que tal pessoa se insere. A partir desse princípio, a interpretação do 'material de adeus' tenta reconstruir essa interrelação entre indivíduo e meio social, tomando o discurso suicida como a última fala deixada por esse sujeito às pessoas ou à sociedade."

Além do conteúdo emocional, que frequientemente revela os motivos do ato extremo e que precisa ser cotejado com o histórico familiar da vítima, deve ser feita a análise do suporte, do instrumento e da gênese da escrita para que se possa verificar se

\footnotetext{
${ }^{223}$ DIAS, Maria Luiza. O suicida e suas mensagens de adeus. In: CASSORLA, Roosevelt Moisés Smeke
} (Org.). Suicídio: estudos brasileiros. Campinas: Papirus, 1991. p. 99. 
realmente foi lavrada de livre e espontânea vontade pelo suicida ou se de alguma forma estava ele sofrendo algum tipo de coação.

Documentos recém-assinados, e que impliquem no estabelecimento ou na rescisão de relações jurídicas, reclamam exame grafotécnico da firma. Escritos de próprio punho com outras especificações ou recomendações também precisam ser analisados por especialista e, em alguns casos, por psicólogos, para que se possam aquilatar as condições em que foi lavrado ou o estado emocional do seu subscritor.

Os suportes (papel, papelão, pedaços de tecido, paredes, piso, etc.), o instrumento de escrita (canetas, lápis, pincéis, partes do corpo como os dedos dos pés ou das mãos), a tinta empregada (tinta de caneta, grafite, sangue, outros materiais orgânicos) são elementos que pedem análise e consideração minuciosas.

\subsubsection{Outras marcas, impressões e sinais}

Seria praticamente impossível elencar de forma exaustiva as marcas, impressões e sinais encontráveis no local do fato. A regra recomenda que tudo o que aparentar ser fora do comum ou que possa eventualmente estar relacionado com o fato em análise (criminoso ou não) deve ser relacionado e preservado.

Evidências aparentemente sem valor, quando posteriormente cotejadas com os testemunhos e demais provas colhidas no processo, revelam-se de grande importância para o esclarecimento do fato. Embora a maioria dos vestígios coletados não conduza a nada, não raro, um deles, ao qual se atribuiu inicialmente relevância menor, pode revelar-se decisivo para a solução do caso.

O perito de local deve ser atento, minucioso e ter sempre em mente a lição de Nerio Rojas $^{224}$ no sentido de que, à semelhança da necropsia malfeita, um levantamento precário de local não poderá ser jamais refeito.

\footnotetext{
${ }^{224}$ ROJAS, Nerio. Medicina legal. 5. ed. Buenos Aires: El Ateneo, 1953. p. 20.
} 


\subsubsection{Vestígios e indícios relacionados com instrumentos, objetos e animais}

\subsubsection{Armas e instrumentos de crimes}

Em um conceito bastante amplo, armas são quaisquer instrumentos, mecanismos, aparelhos ou substâncias aptos a lesar a integridade física de uma pessoa.

As armas dividem-se em próprias, se especialmente fabricadas com a finalidade de ataque ou defesa, e impróprias ${ }^{225}$, quando, embora não tendo sido produzidas para esse propósito, forem empregadas para tal.

As armas próprias subdividem-se em manuais e de arremesso. As primeiras são as utilizadas como um prolongamento do braço, apropriadas para a luta corpo a corpo, como as armas brancas ${ }^{226}$, a massa de guerra ou o soco inglês. As de arremesso são as que produzem o efeito vulnerante à distância de quem a utiliza, como flechas, zarabatanas, fundas e armas de fogo. Estas últimas classificam-se ainda em de arremesso simples, quando o lançamento é feito diretamente pela mão do atirador, e de arremesso complexas, que se compõem de um aparelho arremessador e os objetos utilizados como projéteis ${ }^{227}$.

$$
\text { Armas }\left\{\begin{array}{l}
\text { próprias }\left\{\begin{array} { l } 
{ \text { manuais } } \\
{ \text { de arremesso } }
\end{array} \left\{\begin{array}{l}
\text { simples } \\
\text { complexas }
\end{array}\right.\right.
\end{array}\right.
$$

O exame das armas e instrumentos de crime é tarefa de fundamental importância para a perícia, particularmente nos casos que envolvem o evento morte, e a ele deve ser dedicada a máxima atenção.

O estudo das armas de fogo e do efeito dos seus disparos pertence à balística forense e o das demais armas e instrumentos de crime à traumatologia forense $\mathrm{e}^{228}$. Para $\mathrm{o}$

\footnotetext{
${ }^{225}$ Genericamente denominadas instrumentos de crime, são representadas por fragmentos de madeira, tijolos, pedras, barras de ferro, pedaços de cano e ferramentas diversas.

${ }^{226}$ A expressão "armas brancas" refere-se às armas manuais providas de gume ou ponta, como facas, punhais, canivetes, navalhas, espadas, lanças, baionetas e outras.

${ }^{227}$ RABELO, Eraldo. Balística forense. 3. ed. Porto Alegre: Sagra Luzzatto, 1996. p. 27.

${ }^{228} \mathrm{O}$ estudo dos instrumentos de crime e seus efeitos é feito de acordo com a sua forma de ação, perfurantes, cortantes, contundentes ou de ação composta.
} 
presente trabalho, terá interesse apenas a forma de levantamento das armas e dos vestígios de sua ação.

Tudo aquilo que for positivamente identificado como arma ou possível instrumento utilizado para agressão ou defesa deve ser fotografado no local e posição em que se encontra e preservado para futuros exames.

Ao recolher tais artefatos, o perito precisa ter muito cuidado para não danificar possíveis manchas de interesse e impressões papilares existentes.

Os revólveres e pistolas semi-automáticas podem ser recolhidos com auxílio de um barbante passado pelo "guarda-mato", afastando-os de qualquer contato que possa prejudicar manchas ou impressões existentes (figura 19). Eventualmente poderá ser introduzido no guarda-mato um dedo guarnecido por luva de látex, uma vez que dificilmente serão encontradas impressões nesse espaço. Também, é possível sustentar a arma pelas placas da empunhadura se forem de material áspero e não receptível para impressões papilares. A melhor maneira de tomar a arma, entretanto, vai depender da existência ou não de manchas sobre ela, o que precisa ser verificado antes de qualquer providência. De qualquer modo, nunca se deve recolher a arma introduzindo-se um lápis ou similar no cano porque isso pode prejudicar o exame interno ${ }^{229}$.

Algumas armas possuem uma argola localizada na base da coronha, destinada à colocação de correia de sustentação, que também pode servir para o seu levantamento.

Após o exame da arma no local em que se encontrava, coleta de amostras das manchas e revelação das impressões latentes, ela pode ser encaminhada, em um saco plástico lacrado, para o laboratório de balística para ser submetida a outras análises ${ }^{230}$.

\footnotetext{
${ }^{229}$ PORTO, Gilberto. Manual de criminalística. São Paulo: Escola de Polícia de São Paulo, 1960. p. 254. (Coletânea Acácio Nogueira.)

${ }^{230}$ Como eficácia da arma, aferição de peso do gatilho, recenticidade de disparo, levantamento da numeração, análise de projéteis pelo microscópio comparador balístico e outros.
} 


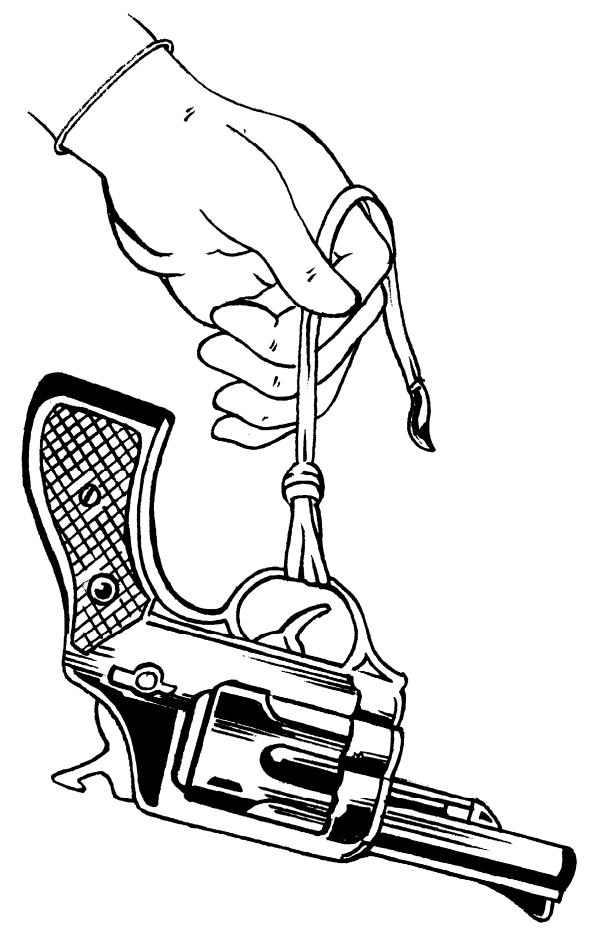

Figura 19 - Modo correto de transportar um revólver.

Os projéteis podem ser recolhidos com os dedos protegidos por luva de látex e colocados em uma caixa de fósforos ou similar, guarnecida com algodão, para evitar danos ao microestriamento, e identificadas. Se estiverem aderidos a cavidades em paredes ou móveis, o perito, após analisar a angulação do disparo, pode recolhê-los, cavando em torno da perfuração e nunca extraindo diretamente o projétil com alicates, chaves de fenda ou outras ferramentas (figura 20). 

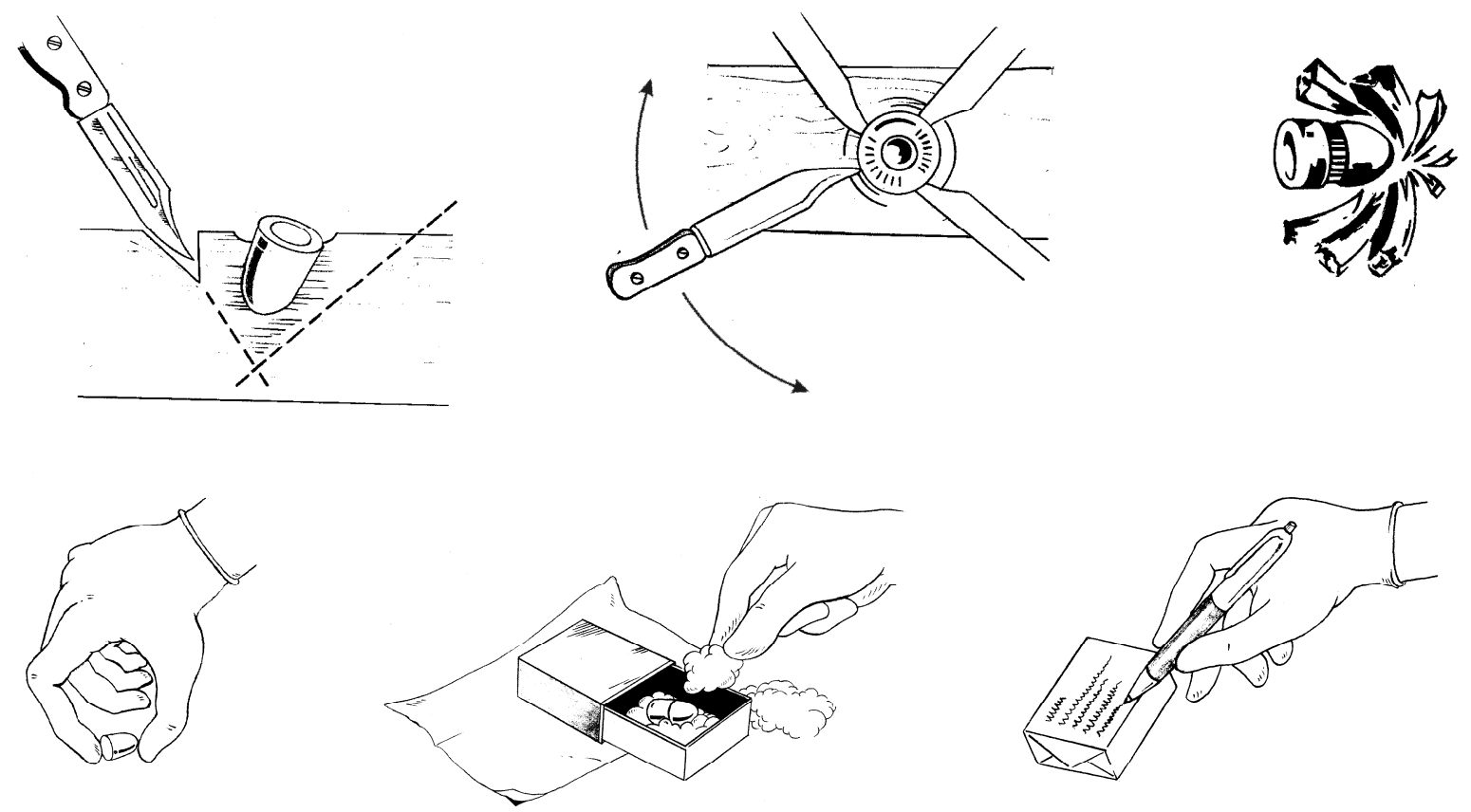

Figura 20 - Modo correto de coletar e acondicionar um projétil.

As armas brancas e demais instrumentos de crime devem receber os mesmos cuidados. Inicialmente são fotografados nos locais e situações em que se encontram e em seguida verifica-se a possível existência de manchas e impressões papilares.

Se não possuírem aderências ou impressões, podem ser recolhidas sem maiores cuidados com as mãos protegidas por luvas de látex.

Apresentando manchas ou impressões, precisam ser recolhidas com extremo cuidado, geralmente pelas partes em que não são observados esses vestígios ou com auxílio de um laço de barbante.

Especificamente em relação às facas, Amado Ferreira recomenda sejam levantadas pela ponta do cabo, colocando-se uma rolha na ponta. 


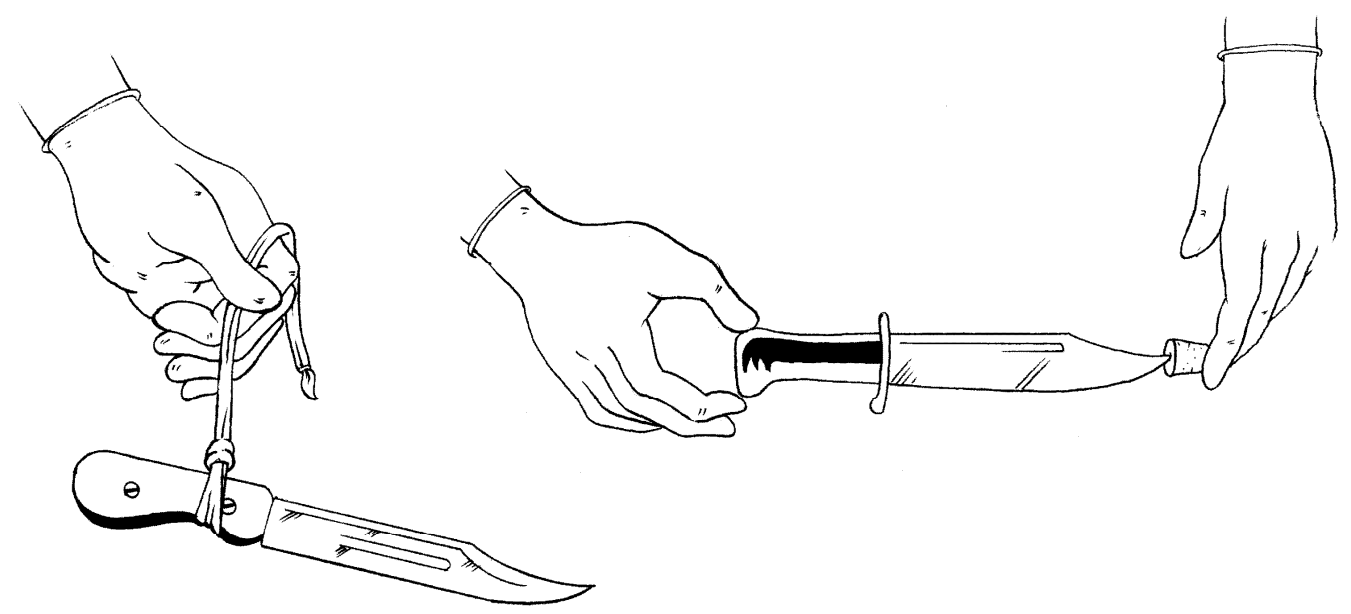

Figura 21 - Modos corretos de manusear armas brancas.

\subsubsection{Cordas, cordéis e similares}

Pedaços de cordas, cordéis, barbantes, fios, correias, fitas ou similares são achados freqüentes e podem ter sido utilizados pelo autor do fato para imobilizar as vítimas, para ter acesso ao local (escalada), para unir ferramentas ou outros materiais por ele levados à cena do crime ou para a retirada de valores (nos delitos patrimoniais).

Além dos produtos pré-fabricados e disponíveis no comércio, existe um tipo particular de corda, manufaturada por presidiários, feita com tiras de lençol ou cobertor, denominada "Teresa", utilizada com inúmeras finalidades ${ }^{231}$. Seu encontro em locais que não sejam estabelecimentos penais, certamente irá indicar que ao menos algum dos autores já esteve institucionalizado.

\footnotetext{
${ }^{231}$ Renato Santos Passos, em "Era uma vez - O coletivo", traz uma pitoresca descrição desse tipo de corda: "A Tereza é um meio de comunicação via cordas. Quem nunca esteve preso duvido que consiga imaginar quanta coisa se transporta por cordas. Talvez possa dizer que a Tereza era a nossa Internet, ou mais. Pequeno exemplo: você quer mandar uma caneca de café quentinho pro amigo de uma cela que fica um pouco afastada da sua. Você pega sua cordinha (pode ser um barbante grosso. Todo preso que se preze tem a sua.), amarra um pãozinho adormecido (duro) numa ponta e o atira pro seu amigo, que a essas alturas está com os dois braços esticados pra fora do guichê da porta da cela. Ele recebe a corda, e fica a segurá-la, firme. Na caneca, você já colocou o café (até uma altura que permita a inclinação da caneca durante o percurso - há ciência e arte nisso). Você, então, enfia a corda por dentro da alça da caneca. Daí pra frente, meu caro, é malabarismo. Mas não se preocupe. No presídio você tem todo o tempo do mundo pra treinar isso exaustivamente" (in PASSOS, Renato Santos. Era uma vez - XIV O coletivo. Santos Passos. Disponível em: <http://www.santospassos.blogspot.com/2004/10/era-uma-vez-xivo-coletivo.html>. Acesso em: 10 jan. 2006).
} 
Além das manchas que podem embeber esses materiais ${ }^{232}$, haverá possibilidade de comparação sempre que uma parte da corda ou similar for encontrada no local do fato e outra parte na posse do suspeito ou em local sob sua responsabilidade.

Se o material for do tipo facilmente encontrado no comércio, feito de fibras vegetais ordinárias como o cânhamo, sisal, fibras sintéticas ou similares, haverá grande dificuldade de comparação e a investigação poderá basear-se nos seguintes elementos ${ }^{233}$ :

a) características físicas, como espessura (total e dos fios constituintes), particularidades das fibras, sua estrutura, número de fios constituintes, orientação, etc.;

b) coloração das fibras e presença de algum material brilhante ou fluorescente;

c) peso total de uma unidade considerada e das partes isoladas;

d) aderências de materiais contaminantes oriundos ou do processo de fabricação ou do local do fato;

e) resistência à tração; e

f) análises química e histoquímica do material.

Essas análises poderão conduzir à conclusão de que os pedaços do material considerado são da mesma espécie. A identificação precisa, entretanto, somente poderá ser feita em casos muito específicos.

Pedaços de algumas espécies de fitas adesivas, da mesma forma, podem ser comparados e a identificação, nesses casos, será mais precisa se as partes foram rasgadas com a mão e as linhas de corte puderem ser cotejadas.

Relacionados com cordas ou similares e também de grande importância para a perícia são os nós. Existem nós para diversas finalidades: de acabamento, de união, para prender objetos, laçadas corrediças e outros. Alguns nós específicos podem indicar profissões determinadas e servir como meio de prova na busca da identificação do autor de um fato.

\footnotetext{
${ }^{232}$ Ver item 2.6.4.12: "O estudo das manchas de sangue no local do fato".

${ }^{233}$ SVENSSON, Arne; WENDEL, Otto. op. cit., p. 164.
} 


\subsubsection{Plantas e animais}

Plantas e animais, dependendo das circunstâncias, podem também se constituir em vestígios ou indícios de importância.

As plantas e suas partes podem interessar sob vários aspectos, por exemplo:

a) plantas atingidas por projéteis de arma de fogo e que podem servir como ponto de apoio para determinação da angulação do disparo ${ }^{234}$;

b) plantas que tenham sido danificadas durante episódio de violência ocorrido no local $^{235}$;

c) folhas e sementes de espécie vegetal que possa conter princípio ativo entorpecente, como, por exemplo, a Cannabis sativa L e as Erythroxylum coca;

d) folhas e sementes de espécie vegetal que possa conter princípio ativo tóxico, no sentido de veneno, como a cicuta ou funcho selvagem (Conium maculatum) ${ }^{236}$;

e) alimentos de origem vegetal que possam estar relacionados com intoxicações alimentares;

f) restos vegetais deixados no local pelo autor do fato e que possam auxiliar na sua localização; e

g) restos vegetais provenientes do local do fato e que possam estar impregnando as vestes e acessórios de possível autor do fato ou que forem encontrados em local sob sua responsabilidade.

Os animais podem apresentar interesse quando forem:

a) agentes de violência praticada contra a pessoa, acidental, dolosa ou culposa, como, por exemplo, pessoas agredidas por cães;

b) objeto de algum tipo de violência relacionada ao caso em análise, como, por exemplo, alvo de disparos de arma de fogo ${ }^{237}$;

\footnotetext{
${ }^{234}$ Em um caso conhecido no Instituto de Criminalística de São Paulo, uma "bala perdida" que atingiu e matou uma criança em um berço, teve o local do disparo determinado porque, antes de atingir a vítima, o projétil transfixou as folhas de uma palmeira, permitindo ao perito auferir a trajetória provável.

${ }^{235}$ Nesses casos geralmente é suficiente o levantamento fotográfico para a constatação da violência.

${ }^{236}$ Particularmente nos casos em que se suspeite de morte por envenenamento.

${ }^{237}$ Em rumoroso caso ocorrido na cidade de São Paulo, após matar a filha a tiros, o pai planejou suicidar-se, fechando-se na garagem da residência com o motor do carro ligado. Antes, porém, para testar a eficácia da câmara de gás improvisada, matou a cadela de sua propriedade da mesma maneira.
} 
c) objeto de algum tipo de violência que, pela sua natureza, possa constituir ilícito penal; e

d) deixados no local ou dele subtraídos pelo autor do fato.

Nos casos em que for necessário o exame do animal, a perícia deverá contar com o auxílio de um médico-veterinário, preferencialmente de instituição pública como o Centro de Controle de Zoonoses.

\subsubsection{Marcas e sinais relacionados com veículos}

Em relação a fatos, criminosos ou não, que atingem bens jurídicos relacionados com a vida ou a saúde da pessoa humana, os veículos irão interessar à perícia nas seguintes hipóteses:

a) acidentes de trânsito; e

b) quando forem utilizados para a prática de outros fatos juridicamente relevantes ou apresentarem vestígios com eles relacionados.

\section{Acidentes de trânsito}

Nos acidentes de trânsito ${ }^{238}$, a função precípua do perito é a de definir da maneira mais clara possível como o acidente ocorreu e a sua causa, o que é feito por intermédio do estudo dos veículos envolvidos e da via pública onde ocorreu o evento. Tudo deve ser identificado, fotografado e anotado.

Com relação à via, o perito precisa atentar para a topografia (reta, curva, plana, aclive, declive, etc.), espécie de superfície de rolamento (asfalto, paralelepípedo, areia, barro, cascalho, etc.), grau de conservação, visibilidade, a presença e o tipo de iluminação pública, sinalização de trânsito, etc.

\footnotetext{
${ }^{238}$ A perícia dos acidentes de trânsito (ou acidentes de tráfego, como preferem alguns autores) é uma das mais complexas e foge ao escopo do presente trabalho, razão pela qual será mencionado apenas perfunctoriamente. Para uma análise profunda sobre o tema recomendamos as obras: NEGRINI NETO, Osvaldo. Dinâmica dos acidentes de trânsito: análises e reconstruções. Campinas, SP: Millennium, 2003. (Tratado de Perícias Criminalísticas. Organizador: Domingos Tochetto) e ARAGÃO, Ranvier Feitosa. Acidentes de trânsito: aspectos técnicos e jurídicos. 3 ed. Campinas, SP: Millennium, 2003. (Tratado de Perícias Criminalísticas. Organizador: Domingos Tochetto).
} 
Os veículos devem ser analisados e fotografados preferencialmente na posição em que foram encontrados após o acidente (posição de repouso). O estado de conservação dos veículos e os sistemas de segurança para o tráfego (direção, freios, luzes de sinalização) precisam ser cuidadosamente apreciados pelo perito para verificar se alguma falha mecânica pode ter contribuído para o acidente. Em seguida, o experto passará ao estudo dos danos e de sua orientação em busca de subsídios para a determinação da dinâmica do acidente.

Não menos importantes são os vestígios deixados pelo acidente sobre o pavimento. $\mathrm{O}$ sítio de colisão ${ }^{239}$, as marcas de frenagem $^{240}$, derrapagem $^{241}$, $^{24 \text { scagem }^{242}}$, arrastamento $^{243}$ e outros sinais característicos reclamam minuciosa análise e consideração pelo perito.

O exame das vítimas e das lesões por elas experimentadas, geralmente contusas ou cortocontusas de grandes proporções, também poderá fornecer elementos para a determinação da dinâmica e das causas do acidente.

Ainda com relação ao exame das vítimas, há um tópico de grande interesse médico-legal, relativo ao exame para verificação de dosagem alcoólica no motorista, objeto de estudo da toxicologia forense e cuja análise foge ao propósito deste trabalho.

\section{Outras hipóteses}

Existe um sem-número de ocorrências que pode envolver o uso de veículos, como suicídio, homicídio, crimes contra os costumes, tráfico de entorpecentes e outros.

Eles podem ser utilizados como meio de execução de um crime ${ }^{244}$; corresponder ao local em que o evento ocorreu ${ }^{245}$; apresentar vestígios relacionados com o fato objeto da

\footnotetext{
${ }^{239}$ Sitio de colisão ou sítio de impacto é a área onde os veículos colidiram ou o local em que o veículo chocou-se contra obstáculo fixo (poste, árvore, outro veículo estacionado, etc.).

${ }^{240}$ Que variam na dependência do tipo de freio considerado, comum ou ABS, e são de extrema importância na determinação da velocidade em que trafegavam os veículos.

${ }^{241}$ São as marcas de atritamento lateral dos pneus sobre o pavimento quando a força centrífuga supera a força de atrito.

${ }^{242}$ São as marcas deixadas no pavimento pelo atritamento das partes metálicas do veículo.

${ }^{243}$ São as marcas pneumáticas produzidas sobre o pavimento quando um veículo desloca o outro lateralmente.

${ }^{244} \mathrm{Um}$ atropelamento doloso ou o transporte de substâncias entorpecentes, por exemplo.

${ }^{245}$ Suicídios, homicídios e crimes contra os costumes são, com freqüência, cometidos no interior de veículos, parados ou em movimento.
} 
perícia $^{246}$ ou ser utilizados apenas e tão-somente como meio de transporte pelos participantes do evento $^{247}$.

Além dos veículos em si, podem ser encontrados nos locais marcas similares àquelas observadas nos acidentes de trânsito ${ }^{248}$, fragmentos de vidro ou de tinta, aderências, manchas e deposições de outras substâncias, como gasolina, graxa, óleos lubrificantes, e um tipo muito particular de vestígio, as marcas de pneumáticos, que abordaremos no tópico seguinte.

Em tendo relação comprovada ou potencial com o fato em apreço, todos esses vestígios devem ser analisados, considerados e preservados pelo perito. As mesmas recomendações tecidas em relação ao levantamento dos locais em geral aplicam-se aos veículos e suas partes, respeitadas as suas peculiaridades ${ }^{249}$.

No caso de fatos envolvendo veículos em movimento, o perito precisa ter o cuidado de, antes de iniciar o exame propriamente dito, colher o maior número de informações possíveis, uma vez que o local mediato e os locais relacionados podem abranger uma área considerável e eventual descuido fazer com que provas importantíssimas sejam perdidas ${ }^{250}$.

\section{Marcas de pneumáticos}

Pneumáticos, ou simplesmente pneus, são aros ou coberturas de borracha, infladas por meio de ar comprimido, que revestem a roda de diversos veículos. É uma das partes mais importantes dos meios de transporte motorizados porque, além de suportar o peso do veículo e de sua carga, faz o contato com o solo, transforma a força do motor em tração e é responsável pela eficiência da frenagem e da estabilidade nas curvas.

\footnotetext{
${ }^{246} \mathrm{Em}$ algumas situações os veículos não guardam nenhuma relação inicial com a ocorrência, mas acabam recebendo vestígios em razão da sua situação no momento do fato. É o caso, por exemplo, de automóveis que recebem disparos provenientes de um tiroteio travado na via pública ou os respingos de sangue de uma vítima esfaqueada nas imediações. Nestes casos, passam a integrar o âmbito de interesse da perícia e devem ser considerados pelo experto.

${ }^{247}$ Embora tenha sido utilizado para a chegada ou saída do local, não apresenta nenhum vestígio de interesse pericial, devendo ser considerado apenas na hipótese de tal circunstância ter alguma relevância para o caso.

${ }^{248}$ Frenagem, derrapagem, sulcagem, arrastamento, etc.

${ }^{249}$ Ver item 2.6.4.12: "O estudo das manchas de sangue no local do fato".

${ }^{250} \mathrm{Um}$ bom exemplo desse tipo de local foi o comentado homicídio do prefeito municipal de Campinas - SP, morto a tiros quando retornava para a sua residência de automóvel. O âmbito da perícia abrangeu praticamente todo o trajeto efetuado pela vítima, do momento em que saiu do shopping em que havia ido fazer compras, até o local em que o veículo se imobilizou contra o pilar de um outdoor.
} 
A estrutura dos pneus é bastante complexa e composta das seguintes partes: carcaça $^{251}$, talões ${ }^{252}$, parede lateral ${ }^{253}$, cintas ou lonas ${ }^{254}$, ombro $^{255}$ e banda de

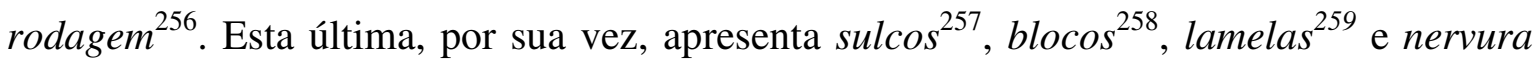
central $^{260}$ (figura 22).

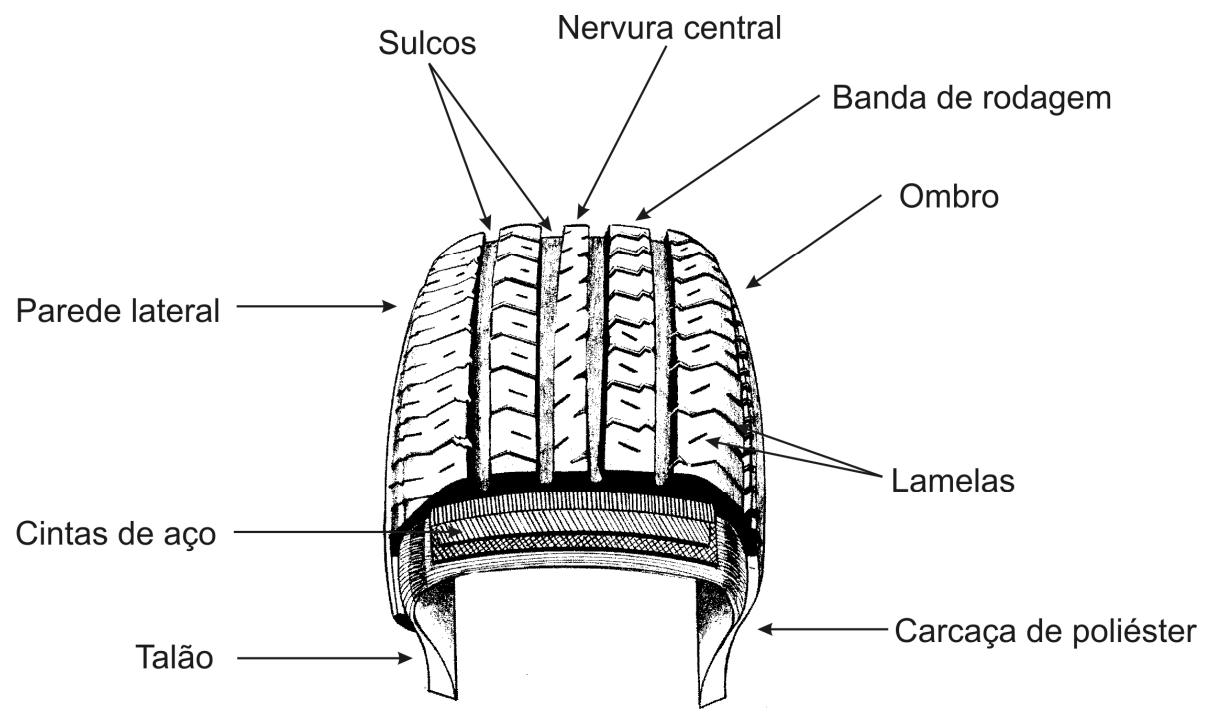

Figura 22 - Estrutura básica dos pneumáticos.

As marcas produzidas pelos pneumáticos apresentam as seguintes finalidades ${ }^{261}$ :

a) identificar a espécie de veículo utilizado;

b) determinar a direção tomada pelo mesmo; e

${ }^{251} \mathrm{~A}$ carcaça é a parte do pneu, geralmente composta por lonas de poliéster, que deve resistir à pressão, ao peso e aos choques.

${ }^{252}$ Formados por fios de aço de grande resistência, os talões têm por finalidade manter o pneu fixado ao aro da roda.

${ }^{253}$ As paredes laterais dos pneus são revestidas por um tipo especial de borracha com alto grau de flexibilidade e resistência à fadiga.

${ }^{254}$ As cintas ou lonas estabilizadoras têm por função garantir a área de contato necessária entre o pneu e o solo de modo a proporcionar dirigibilidade. Geralmente são tecidas em rayon ou arame de aço fino e dimensionadas para suportar cargas em movimento.

${ }^{255}$ Local do pneu onde ocorre a junção da banda de rodagem com a lateral.

${ }^{256} \mathrm{~A}$ banda de rodagem é a parte do pneu que toca diretamente o solo. É constituída por um tipo especial de borracha formada de elastômeros e seus desenhos variam de pneu para pneu. Possuem partes cheias denominadas blocos ou "biscoitos" e partes vazadas que correspondem aos sulcos.

${ }^{257}$ Os sulcos são cavidades longitudinais na banda de rodagem que têm por finalidades evitar deslizamentos laterais, escoar água ou detritos, refrigerar o pneu e gerar tração.

${ }^{258}$ Vulgarmente conhecidos como "biscoitos" os blocos correspondem à parte da banda de rodagem que efetivamente se atrita com o solo. Têm também a finalidade de conferir flexibilidade ao pneu.

${ }^{259}$ Lamelas são pequenos cortes distribuídos de forma homogênea por toda a banda de rodagem. Têm por finalidades oferecer maior mobilidade aos blocos e ampliar seus movimentos quando sob forte solicitação.

${ }^{260}$ É a parte média da banda de rodagem.

${ }^{261}$ Excluída a hipótese de acidente de trânsito, em que a análise desses vestígios auxilia o perito a reconstituir a dinâmica do evento. 
c) identificar, especificamente, o veículo que esteve no local.

É claro que as características morfológicas das marcas de pneumáticos dependem muito da natureza e do estado do pavimento sobre o qual o veículo se desloca. No asfalto e nos pisos de concreto são praticamente invisíveis e, além da espécie de veículo, sua direção e sentido de deslocamento pouco podem trazer à perícia. Já nos pisos de terra e lama, a impressão deixada pela banda de rodagem, em alguns casos, serve como elemento de identificação.

É sempre bom lembrar, também, que, quando o veículo se desloca em trajetória retilínea para frente, as impressões das rodas traseiras se sobrepõem às marcas das rodas dianteiras, ocorrendo o oposto quando o deslocamento se dá em marcha a ré.

A espessura e o tipo dos pneus ${ }^{262}$, o número de rodas e o afastamento entre os eixos podem conduzir à determinação da espécie de veículo utilizado, que pode ser motocicleta, automóvel, caminhonete, caminhão, utilitário agrícola ou outro.

A determinação da direção tomada pelo veículo nem sempre é possível. Apenas em certas hipóteses isso será verificado:

a) quando o veículo passou sobre água ou outro líquido, as marcas deixadas vão secando de trás para frente. Se tais vestígios forem encontrados, o que é raro, porque desaparecem rapidamente, será possível determinar a direção do deslocamento;

b) se do veículo se desprendem gotas de algum líquido de secagem lenta, como óleo do motor, ou pó de alguma espécie;

c) quando o leito é de areia ou terra, à medida que a roda do veículo se desloca, os torrões levantados do solo se orientam no sentido do deslocamento.

A tentativa de identificação individual do veículo só será possível em casos muito particulares em que a impressão dos pneus foi deixada sobre um terreno que permita a formação em baixo relevo dos desenhos da banda de rodagem.

Nesses casos procede-se à fotografação e modelagem das impressões deixadas, com as mesmas técnicas preconizadas para o levantamento de pegadas.

\footnotetext{
${ }^{262} \mathrm{O}$ confronto inicial das marcas e modelos dos pneumáticos deve ser feito por intermédio dos padrões fornecidos pelos principais fabricantes, inclusive para pneus recauchutados. Existem alguns métodos de classificação de pneus, como o de Heindl, mas que, na prática, mostraram-se pouco úteis ante a grande variedade de tipos e modelos. A melhor solução é ainda a de procurar as fábricas na tentativa de identificar os desenhos específicos das bandas de rodagem.
} 
Além do desenho característico dos vários tipos de pneus, para uma identificação precisa de um veículo em particular é preciso procurar por marcas que possam significar desgastes ou defeitos e que permitam uma comparação com o original.

Em alguns atropelamentos, marcas de pneumáticos podem ser encontradas sobre o corpo da vítima, mas, além do tipo de veículo, dificilmente permitirão uma identificação mais precisa.

\subsubsection{Marcas de instrumentos}

Marcas de ferramentas e objetos utilizados como ferramentas são achados freqüentes nos locais submetidos a exames periciais, particularmente aqueles relacionados com delitos patrimoniais. Essas marcas, produzidas por instrumentos variados, como talhadeiras, machados, canivetes, alicates, tesouras, chaves de fenda, pés-de-cabra e similares, podem ser encontradas sobre diversos suportes, como madeira, metal ou paredes $^{263}$ e podem ser produzidas por atritamento (talhadeiras, limas, serras, etc.) ou compressão (martelos, alicates, pés-de-cabra, etc. $)^{264}$.

Além disso, quanto à presença ou não de detalhes identificadores, podem ser:

a) marcas em que apenas o tamanho e a forma da ferramenta são deixados sobre o suporte, permitindo, no máximo, a identificação do tipo de instrumento utilizado; e

b) marcas em que as irregularidades e defeitos da ferramenta são impressas no suporte. Essas marcas, embora dificilmente possam levar a uma identificação individual e incontestável do instrumento, podem ser utilizadas para incluir ou excluir uma ferramenta suspeita como possível causadora da danificação considerada.

Todas as marcas que revelem estriamentos, endentações ou sinais particulares são, assim, extremamente valiosas para a perícia e, sempre que possível, devem ser recolhidas no original, ou seja, a parte do material contendo o vestígio deve ser encaminhada ao laboratório para comparação ou análise.

\footnotetext{
${ }^{263} \mathrm{Nem}$ todos os suportes são hábeis a permitir uma impressão de utilidade. Os cabos e objetos de borracha, por exemplo, pela sua elasticidade, dificilmente produzirão vestígios de utilidade.

${ }^{264}$ Embora as ferramentas sejam produzidas para uma determinada finalidade, dependendo da forma em que foram utilizadas podem produzir um ou outro tipo de marca. Assim, o perito deve estar atento não apenas para o tipo de instrumento utilizado como também para o modo como foi empregado.
} 
Se a retirada for impossível, a melhor solução será a de manter o vestígio preservado no local até que uma ferramenta suspeita seja localizada para comparação. Apenas em último caso se preservará a evidência apenas por fotografia ou modelagem ${ }^{265}$.

Ao fazer o levantamento do local, o perito deve procurar por marcas de aspecto recente, pois existe sempre a possibilidade do encontro de vestígios não relacionados. Os vestígios comprovadamente recentes e relacionados com o fato em análise precisam ser levantados e o investigador atento não pode esquecer a possibilidade de terem sido produzidos por ferramentas utilizadas em outros delitos. Uma comparação entre casos catalogados pode levar à solução de inúmeros inquéritos policiais ${ }^{266}$.

No exame da marca deixada pelo instrumento, o perito precisa imaginar-se na posição do autor. Como ele teria segurado e aplicado a ferramenta para produzir o vestígio encontrado. Isso é importante porque um arrombamento pode ser simulado para camuflar um furto praticado por empregados ou fraude contra seguros. Assim, é necessário verificar se os vestígios foram deixados por alguém que realmente procurava produzir o dano encontrado ou apenas deixar uma marca com a finalidade de iludir a perícia.

O conhecimento da dinâmica dos arrombamentos é fundamental. Há casos em que a força é aplicada em um ponto, mas os vestígios são produzidos em outro e o perito precisa estar atento para essa circunstância ${ }^{267}$.

A marca deve ser examinada com atenção, primeiro para estabelecer a identificação genérica da ferramenta e depois, se presentes os elementos necessários, para sua individualização. A comparação pode ser feita de forma direta com a ferramenta suspeita, ou aplicando o instrumento sobre suportes semelhantes para cotejar os danos produzidos.

\footnotetext{
${ }^{265}$ As técnicas de modelagem, na hipótese, têm muito pouca utilidade, porque não preservam o estriamento fino necessário à comparação. No máximo poderão indicar a natureza e o tamanho da ferramenta que produziu o dano.

${ }^{266}$ Lamentavelmente, esse trabalho de comparação de vestígios encontrados em locais diversos é praticamente inexistente no Brasil e realizado apenas em casos de extrema repercussão em que desde o início se suspeita de crimes praticados em série.

${ }^{267}$ Em rumoroso caso ocorrido no estado de São Paulo, uma pessoa estava sendo acusada de assassinar toda a família. A afirmação se baseava no fato de que uma porta arrombada apresentava vestígios junto à fechadura do lado interno, o que fez a Promotoria de Justiça pensar em uma simulação. A perícia demonstrou, de forma inequívoca, que a força havia sido aplicada do lado externo da folha da porta e que os vestígios foram produzidos na face interna pela rotação da fechadura em seu encaixe.
} 
No caso das marcas produzidas por atrito, o perito precisa estar atento para o fato de que o espaçamento entre as estrias varia de acordo com o ângulo em que a ferramenta foi aplicada ${ }^{268}$ (figura 23).

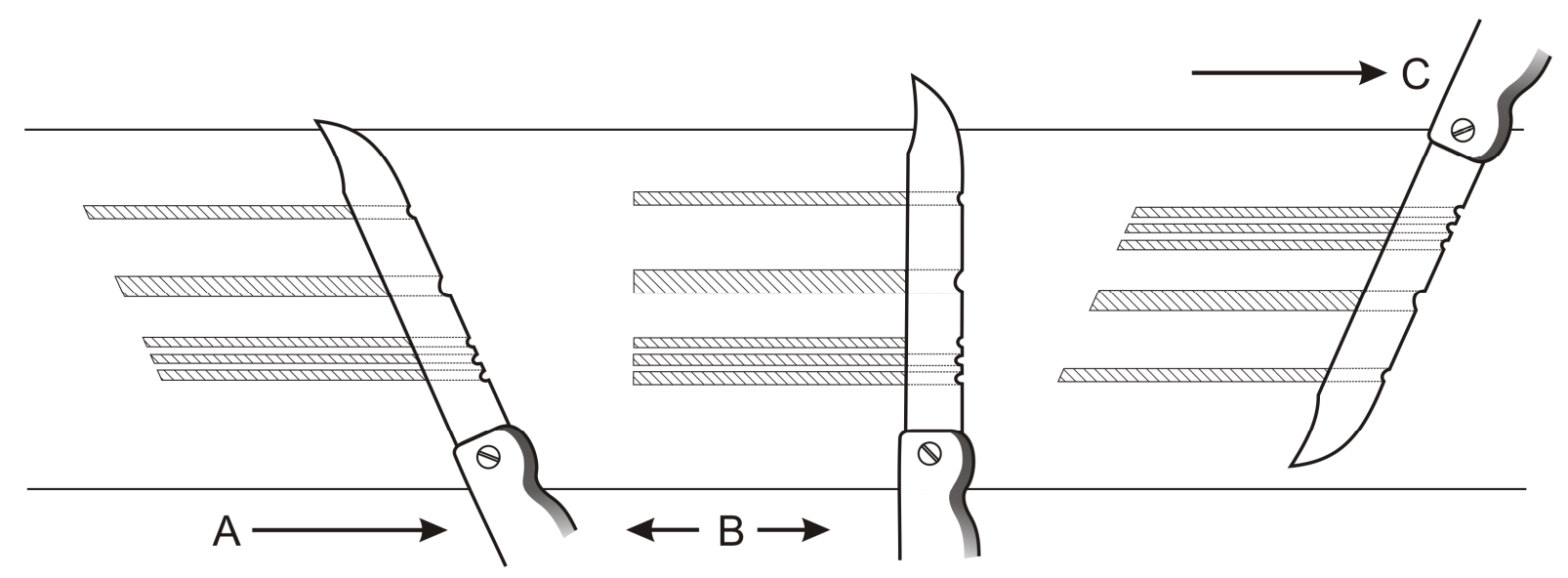

Figura 23 - Variação das marcas de acordo com a forma de incidência da ferramenta.

O exame da ferramenta suspeita também deve ser cuidadoso, atentando o perito para o fato de que ela pode ainda carregar vestígios oriundos do suporte, como aderências de madeira, óleo ou tinta, extremamente úteis na confirmação de sua utilização.

\section{Fragmentos de ferramentas}

Os locais em que forem encontrados sinais de arrombamento necessitam ser minuciosamente vistoriados pelo perito em busca de possíveis fragmentos das ferramentas encontradas. Não raro, em razão do esforço empregado, os instrumentos podem deixar fragmentos de tamanhos variados que permitem a comparação com o instrumento original, encontrado em posse da pessoa suspeita.

\subsubsection{6. Álcool, medicamentos e entorpecentes}

Substâncias e medicamentos encontrados no local e que possam estar relacionados com o fato em análise precisam ser recolhidos e identificados pelo perito, notadamente se

\footnotetext{
${ }^{268}$ Se a ferramenta correr perpendicularmente sobre o suporte (B), a distância entre os estriamentos será maior que aquela observada quando é aplicada angularmente (A). Também haverá diferença na direção do corte se o instrumento for seguro pela mão direita (A e B) ou (C) pela mão esquerda (apud Svenson \& Wendel, 1971, p. 107).
} 
houver suspeita ou confirmação de sua natureza entorpecente ou se as investigações apontam no sentido de envenenamento (acidental, suicida ou criminoso).

Da mesma forma, garrafas, copos e xícaras contendo bebidas alcoólicas ou outras não identificadas, precisam ser consideradas cuidadosamente antes de serem descartadas pelo experto.

Uma vez fotografados no local em que foram encontrados, recolhidos e identificados, esses materiais necessitam ser encaminhados ao laboratório para exames complementares. Em se tratando de evento morte, é imprescindível que o médico-legista seja informado do achado para que possa orientar a necropsia e recolher do corpo as amostras necessárias.

\subsubsection{Manchas inorgânicas}

Manchas inorgânicas, para efeito desse trabalho, são todas aquelas não provenientes de líquidos ou secreções fisiológicas de origem humana ou de animal, já estudadas.

Dentre elas, assumem importância as manchas ou deposições de cera, parafina ou estearina $^{269}$, ferrugem ${ }^{270}$, terra e lama $^{271}$, tintas diversas ${ }^{272}$, pólvora ${ }^{273}$, substâncias $\operatorname{graxas}^{274}$ e outras. Todas essas substâncias terão importância quando de alguma forma puderem vincular uma pessoa ao fato, principalmente quando tal indivíduo nega categoricamente ter estado no local.

\footnotetext{
${ }^{269}$ As manchas de cera, parafina ou estearina são esbranquiçadas e podem eventualmente ser confundidas com substâncias orgânicas como pus ou esperma.

${ }^{270}$ Geralmente encontradas em peças metálicas, as manchas de ferrugem indicam o tempo aproximado em que a peça esteve em contato com agentes oxidantes. Excepcionalmente, as manchas de ferrugem podem ser observadas em tecidos e, nessas hipóteses, indicar o uso de um instrumento impregnado ou vincular uma pessoa suspeita ao local do fato e vice-versa.

${ }^{271}$ Têm importância na medida em que podem indicar os lugares por que passou a pessoa suspeita. Podem ser deixadas no local pelo autor ou, hipótese mais freqüente, carregadas por ele do cenário em suas vestes ou, principalmente, em seus calçados.

${ }^{272}$ As manchas de tinta são comumente encontradas nas vestes ou nas mãos da pessoa suspeita, por ter ela se apoiado ou encostado em superfície revestida com tinta não completamente seca ou passível de abrasão. É possível também a contaminação com tinta em sua forma líquida, ou seja, ainda não aplicada sobre qualquer superfície. Em qualquer caso, o exame consiste na comparação inicial pela textura e pela cor e, se necessário, na análise química comparativa entre a tinta recolhida das vestes ou das mãos do suspeito e aquela retirada do local questionado.

${ }^{273}$ As manchas de pólvora têm um significado muito especial para a Balística Forense.

${ }^{274}$ Assim como a tinta, a graxa também pode aderir às vestes ou corpo do autor do fato e servir como elemento de vinculação ao local. O exame, da mesma forma, é feito por análise química e comparação.
} 


\subsubsection{Produtos químicos diversos}

Inúmeros produtos químicos podem ser encontrados no local e manter relação com a ocorrência, notadamente nos casos suspeitos de envenenamento (acidental, suicida ou criminoso). Os produtos mais comuns são os combustíveis (álcool e gasolina), tintas, água sanitária, soda cáustica, inseticidas, pesticidas, produtos de limpeza (sabões e detergentes) e solventes diversos.

Havendo possibilidade de tais produtos estarem relacionados com a ocorrência, devem ser fotografados, identificados e encaminhados ao laboratório para análise. O médico-legista precisa ser informado para que possa orientar a necropsia e proceder à coleta das amostras orgânicas necessárias.

\subsubsection{Poeira e cinzas}

Quando analisamos os vestígios que podiam ser encontrados nas vestes ${ }^{275}$, dissemos que poeira é a terra seca ou qualquer substância reduzida a partículas muito finas, capazes de pairar no ar, ainda que por curto espaço de tempo, e que podiam ser divididas em:

c) poeiras profissionais; e

d) outras poeiras.

As poeiras profissionais são aquelas encontradas no ambiente de trabalho de determinadas profissões, como marcenarias, carpintarias, serralherias, aplicadores de gesso, construções e outros. As demais espécies de pós, incluindo a poeira doméstica ${ }^{276}$, não se relacionam com nenhum ofício em particular e podem ser encontrados nos mais variados lugares e situações.

Com relação à origem, as poeiras podem ser classificadas, ainda, em:

a) vegetais - poeiras oriundas de madeira, algodão, linho, cânhamo, etc.;

\footnotetext{
${ }^{275}$ Ver item 2.6.4.33: "peças de vestuário e acessórios".

${ }^{276}$ A poeira doméstica, responsável por inúmeras afecções respiratórias, é, na verdade, uma mistura de substâncias variadas, podendo ser encontrados, entre outros componentes, microfibras, pólen, descamações de pele, esporos e fungos, partes de insetos e aracnídeos, partículas de caliça, excrementos de ácaros, além dos próprios ácaros (Dermatophagoides pteronyssinus).
} 
b) minerais - cimento, óxido de cálcio (cal), sulfato de cálcio (giz e gesso), etc.;

c) animais - poeiras decorrentes de descamações da pele, pêlos, lã e outros.

Além das vestes, as poeiras podem se depositar sobre o piso, cortinas, tapetes, móveis e objetos. Os pós podem ser de grande auxílio à perícia, não apenas quando encontrados na indumentária do suspeito, mas porque denunciam algumas atividades ocorridas no local.

Nas escaladas, por exemplo, o pó que se desprende da parede (caliça) fica depositado no piso, indicando o lugar de acesso utilizado pelo autor. Nos locais muito empoeirados e que não são limpos há muito tempo, a poeira opera no sentido oposto, indicando claramente os lugares que foram tocados ou alterados. Em alguns casos, a poeira aderida às mãos do agente pode produzir algumas impressões papilares visíveis, em papéis ou objetos receptivos.

Quando demonstrarem interesse como evidência ou objetivando uma possível comparação futura, as poeiras devem ser recolhidas com cautela, acondicionadas em envelopes plásticos lacrados e encaminhadas ao laboratório. A recolha pode ser feita com espátulas ou com auxílio de um aspirador especial absolutamente livre de contaminação.

$\mathrm{Na}$ maioria das vezes o exame comparativo é feito com auxílio de um microscópio. Em se tratando de pós de origem mineral a análise química também é possível.

\section{Cinzas}

As cinzas são os resíduos provenientes da combustão de determinadas substâncias. Como já salientamos anteriormente, apenas em casos muito excepcionais as cinzas poderão fornecer algum subsídio real para a perícia.

As mais comuns, encontradas nos locais submetidos a exames periciais, são as provenientes de cigarros e charutos. Essas cinzas irão adquirir maior importância nos casos em que a vítima e seus familiares não fumavam; daí a recomendação feita para que o policial que preserva o local não fume.

O recolhimento e o acondicionamento das cinzas podem ser feitos da maneira recomendada para as poeiras. 
A composição química das cinzas varia grandemente na dependência do material comburido. O exame pode ser microscópico, espectroscópico ou químico ${ }^{277}$ e objetiva a identificação dos principais componentes. A fonte de origem da cinza, entretanto, dificilmente poderá ser determinada.

Tanto para as cinzas como para as poeiras, atualmente é possível a microanálise de raios $\mathrm{X}$ por $\mathrm{EDS}^{278}$, embora a complexidade e o custo do exame não o tornem uma escolha de rotina.

\section{Documentos queimados}

Documentos total ou parcialmente queimados podem ser de grande valor para a investigação, pois, como é sabido, o fogo é costumeiramente empregado como meio para a prática de fraudes contra seguros ou de destruição de provas.

Se estiverem mais ou menos intactos, os papéis e documentos queimados podem ser decifrados pelo perito, razão pela qual se recomenda extremo cuidado na sua remoção e preservação. A melhor técnica é a de recolher e transportar esses materiais no local em que se encontram (interior de um arquivo, cesto de lixo ou gaveta).

Se o material queimado corresponder a livros, papéis dobrados ou maços de dinheiro, não devem ser separados ou abertos no local, mas transportados para o laboratório onde, com técnicas e locais apropriados, seus conteúdos poderão, eventualmente, ser levantados.

O tratamento químico das cinzas, a fotografia e o exame sob luz ultravioleta são algumas das técnicas que podem tornar legível a escrita de papéis queimados. Entretanto, para que isso seja possível, os documentos devem chegar intactos ao laboratório.

Lamentavelmente, no caso de incêndios, a intervenção humana para a contenção do fogo geralmente faz perder a maior parte desses vestígios.

\footnotetext{
${ }^{277} \mathrm{O}$ exame químico não é recomendado por ser muito trabalhoso e demorado, além de não apresentar resultados satisfatórios (KEHDY, Carlos. op. cit., p. 204).

${ }^{278}$ Energy Dispersive Spectrometer.
} 


\subsubsection{Papéis, cartas, livros, documentos, gravações, filmes, fotografias e outros}

Papéis, cartas, livros, documentos, fitas gravadas, fotografias, filmes e outros materiais que possam guardar relação com o fato objeto da perícia devem ser cuidadosamente analisados e considerados.

Além dos papéis deixados pela própria vítima e já considerados ${ }^{279}$, outras cartas e documentos encontrados no local podem dar à investigação a noção de compromissos financeiros assumidos, de extorsão ou ameaças experimentadas pelo ofendido ou, ainda, de relações sentimentais entre ele e terceiras pessoas, fatos que com certeza serão de capital importância para esclarecer da natureza jurídica do evento e para determinar a identidade do autor de um fato tido como criminoso.

Fitas gravadas, conteúdo de secretárias eletrônicas, mensagens deixadas na caixa postal de celulares, fotografias e filmes precisam ser levantados e analisados pelo perito, principalmente nos casos de homicídio ou crimes de natureza sexual.

\subsubsection{Programas e arquivos de computador}

O exame do conteúdo dos discos rígidos dos computadores, disquetes, CDs e similares, eventualmente encontrados no local ou em posse de pessoas suspeitas, constituem, atualmente, importante auxiliar na investigação criminal não apenas em relação aos chamados crimes de informática ${ }^{280}$, mas também nas investigações relacionadas com homicídios, crimes sexuais e patrimoniais.

O estudo da caixa postal da vítima e das páginas da Internet visitadas pode revelar relações com terceiras pessoas, até então desconhecidas pelos familiares, mas de fundamental importância para o esclarecimento do fato.

\footnotetext{
${ }^{279}$ Ver item 2.6.4.35: "escritos e desenhos".

${ }^{280}$ Embora o estudo dos crimes de informática não seja objeto do presente trabalho, para maiores informações recomendamos a leitura da obra ANTONIO, Marcelo; COSTA, Sampaio Lemos. Computação forense. 2. ed. Campinas, SP: Millennium, 2003. (Tratado de Perícias Criminalísticas. Organizador: Domingos Tochetto).
} 
Os documentos, fotografias e filmes digitalizados permitirão ao perito traçar um perfil das atividades e interesses da vítima ou do possível autor, facilitando em muito a investigação.

Apenas para se ter uma idéia da importância desses registros, ainda não plenamente considerados pela perícia, recentemente "o registro das atividades de um acusado na Internet serviu para condenar um assassino. Provou-se que Robert Petrick, suspeito de matar a mulher, Janine, em 2003, havia procurado no Google as palavras 'pescoço', 'quebrar', 'partir' e 'segurar' quatro dias antes do crime. Também pesquisou a profundidade do lago onde jogou o corpo"281.

Para o exame de arquivos eletrônicos recomenda-se a duplicação da mídia de prova para preservação. $\mathrm{O}$ exame direto dos arquivos só deve ser feito excepcionalmente.

\subsubsection{Outros vestígios e indícios materiais}

Como já dissemos, seria praticamente impossível elencar de forma exaustiva as marcas, impressões e sinais encontráveis no local do fato. A regra aconselha que tudo o que aparentar ser fora do comum ou que possa eventualmente estar relacionado com o fato em análise (criminoso ou não) deve ser relacionado e preservado ${ }^{282}$.

O perito deve ter em mente que evidências aparentemente sem valor, quando posteriormente cotejadas com os testemunhos e demais provas colhidas no processo revelam-se de grande importância para o esclarecimento do fato. Embora a maioria dos vestígios coletados não conduza a nada, não raro, um deles, ao qual se atribuiu inicialmente relevância menor, pode revelar-se decisivo para a solução do caso.

\footnotetext{
${ }^{281}$ TRAÍDO pelo teclado. Revista Época, São Paulo, no 401, p. 11, jan. de 2006. <http://revistaepoca.globo.com/Revista/Epoca/0,EDG72941-6014,00-PRIMEIRO+PLANO.html>.

${ }^{282}$ A título de exemplo mencionamos um caso solucionado pelo Departamento de Homicídios e Proteção à Pessoa (DHPP) em que o corpo da vítima foi envolvido por um pedaço de lona plástica roxa. A outra parte da lona foi encontrada forrando a cama do suspeito. Cotejados os retalhos ficou comprovada a autoria do homicídio. Outro crime foi resolvido porque o perito recolheu, do piso da sala em que estava o corpo da vítima, um palito de fósforo com haste de cartolina. Esse palito, posteriormente cotejado com a cartela encontrada no bolso do suspeito, comprovou que ele esteve no local, o que negava categoricamente.
} 


\subsubsection{Vestígios e indícios mistos - sinais de luta}

Uma das mais delicadas conclusões a que pode chegar o perito em locais relacionados ao evento morte é a da presença ou ausência dos chamados sinais de luta, isto porque, em última análise, essa constatação orienta o diagnóstico jurídico no sentido de um fato definido como crime.

Como regra geral, nos acidentes e nos suicídios, os sinais de luta devem estar ausentes, podendo ser encontrados em alguns homicídios, crimes sexuais e delitos patrimoniais com resultado fatal.

Nos locais internos, os sinais de luta traduzem-se por desordem generalizada, acompanhada por móveis deslocados, tombados e quebrados, objetos diversos espalhados pelo chão, presença de manchas de sangue, vidros estilhaçados, vasos caídos, plantas danificadas e pisoteadas, fios partidos e, eventualmente, o encontro dos instrumentos utilizados para a agressão, como pedaços de madeira, pedras, barras de ferro, etc.

Nos locais externos a constatação é mais difícil. Se o piso for de terra, estará revolvido, pisado e em desordem. As árvores e arbustos, porventura existentes nas imediações, apresentarão galhos partidos e folhas arrancadas. Poderão ser observadas manchas de sangue e os instrumentos utilizados para a agressão.

Sendo o piso de asfalto ou concreto, como em uma via pública, por exemplo, os sinais de luta irão se restringir a possíveis manchas de sangue, cuja dinâmica deve ser considerada.

As vestes da vítima e do provável autor também mostrarão vestígios reveladores. Além de manchas de sangue, as roupas estarão em completo desalinho, com partes sujas e rasgadas, ausência de botões, etc.

Finalmente, além dos vestígios encontrados no local e nas vestes, o corpo da vítima poderá apresentar ferimentos recebidos durante a luta e que não se confundem com os que lhe causaram o óbito.

Quando tais vestígios e indícios materiais estiverem presentes e evidentes, o perito poderá concluir pela existência de luta e, conseqüentemente, por uma morte de etiologia provavelmente criminosa. 
Existem algumas situações, entretanto, em que a aparência do local, de per si, não irá permitir ao perito afirmar ou infirmar a existência de luta ou a etiologia do fato, sendo necessário buscar outros elementos de convicção. São elas:

a) violência exercida para impedir suicídio;

b) violência praticada pelo suicida em razão de seu estado mental;

c) simulação praticada pelo suicida ou por terceiros para encobrir o ato extremo; $\mathrm{e}$

d) simulação praticada por terceiros para encobrir um crime.

\section{Violência exercida para impedir suicídio}

O suicídio em si, o ato de tomar a própria vida, não é típico para o Direito Penal pátrio, mas apenas a participação no ato extremo de terceiro, o que pode ocorrer nas modalidades, auxílio, induzimento ou instigação (art. 122 do CP).

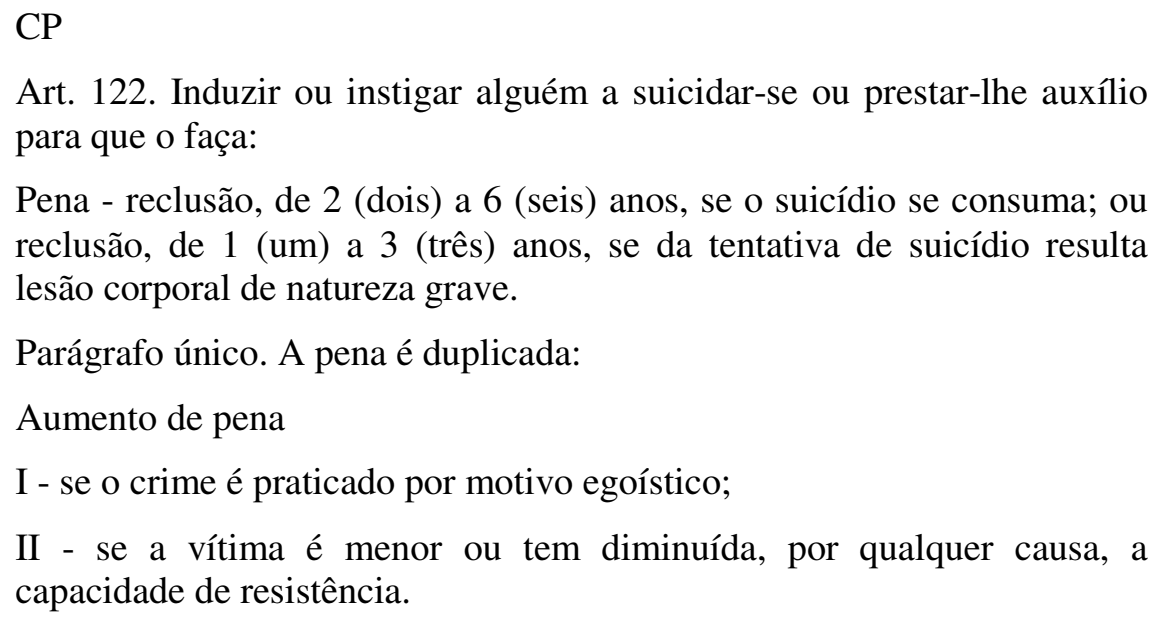

Art. 122. Induzir ou instigar alguém a suicidar-se ou prestar-lhe auxílio para que o faça:

Pena - reclusão, de 2 (dois) a 6 (seis) anos, se o suicídio se consuma; ou reclusão, de 1 (um) a 3 (três) anos, se da tentativa de suicídio resulta lesão corporal de natureza grave.

Parágrafo único. A pena é duplicada:

Aumento de pena

I - se o crime é praticado por motivo egoístico;

II - se a vítima é menor ou tem diminuída, por qualquer causa, a capacidade de resistência.

A contrário senso, a intervenção, ainda que violenta, para impedir que a vítima tire a própria vida, é causa de exclusão da ilicitude que afasta o constrangimento ilegal (art. $\left.146, \S 3^{\circ}, \mathrm{II}\right)$.

\section{$\mathrm{CP}$}

Art. 146. ...

$\S 3^{\circ}$ Não se compreendem na disposição deste artigo:

II - a coação exercida para impedir suicídio. 
É possível, assim, em caso de suicídio comprovado, que alguma pessoa possa ter entrado em luta corporal com a vítima na tentativa, infrutífera, de impedir a consumação da autoquíria. Existirão vestígios de luta, mas tais vestígios não poderão levar à conclusão da ocorrência de crime.

Para que possa fazer esse diagnóstico diferencial, o perito precisará verificar como ocorreu o suicídio, os antecedentes psicológicos da vítima e da pessoa interveniente e, principalmente, se as declarações dessa última encontram respaldo nos vestígios encontrados.

\section{Violência praticada pelo suicida em razão de seu estado mental}

Não raro, o suicida pratica atos de violência no local antes de consumar o ato extremo. Isso pode ocorrer em razão de perturbação mental ou para testar o método que será utilizado na consecução de seu objetivo.

No primeiro caso a violência é bem mais evidente. Móveis quebrados, objetos atirados ao chão, papéis espalhados e outros vestígios irão denunciar a insanidade. É possível, inclusive, que em seu acesso de fúria a vítima possa ferir-se em alguma das coisas atingidas.

O perito precisará utilizar todo o seu tirocínio e experiência para verificar se os ferimentos e danos observados no ambiente poderiam ter sido praticados apenas pelo suicida. A análise dos antecedentes psicológicos da vítima, nesses casos, é de fundamental importância.

Na segunda hipótese, a violência, quando existe, é dirigida para uma finalidade específica, a experimentação do meio a ser utilizado no ato extremo. Nesses casos é relativamente simples, para um perito experimentado, identificar os danos característicos.

Se o método de eleição for o seccionamento de vasos do pulso, poderão existir manchas de sangue espalhadas pelo local de forma irregular. Se utilizar arma de fogo, poderão ser encontrados disparos de teste realizados contra móveis e paredes. Se houver precipitação, é provável que alguns móveis estejam deslocados para a proximidade de janelas ou sacadas e, nesses procedimentos, derrubados ou danificados alguns objetos. Se for escolhido o enforcamento, algumas cordas e ferramentas podem estar espalhadas pelo piso e assim por diante. 


\section{Simulação praticada pelo suicida ou por terceiros para encobrir o ato extremo}

A hipótese é de suicídio, mas ou a própria vítima ou terceiras pessoas alteraram o local para fazer crer que houve um crime.

Embora raro, isso pode ocorrer quando o suicida pretende mascarar seu ato por receio de reprovação social ou familiar, questões de ordem religiosa ${ }^{283}$, visando confundir a perícia em razão de um desequilíbrio mental ou para incriminar deliberadamente terceiros.

O método utilizado não pode ser evidente. Geralmente a vítima opta pela precipitação, atira-se sobre uma faca (figura 24) ou outro objeto pontiagudo, utiliza arma de fogo de maneira totalmente atípica (figura 24), ou produz no local uma simulação de luta ou de subtração patrimonial.
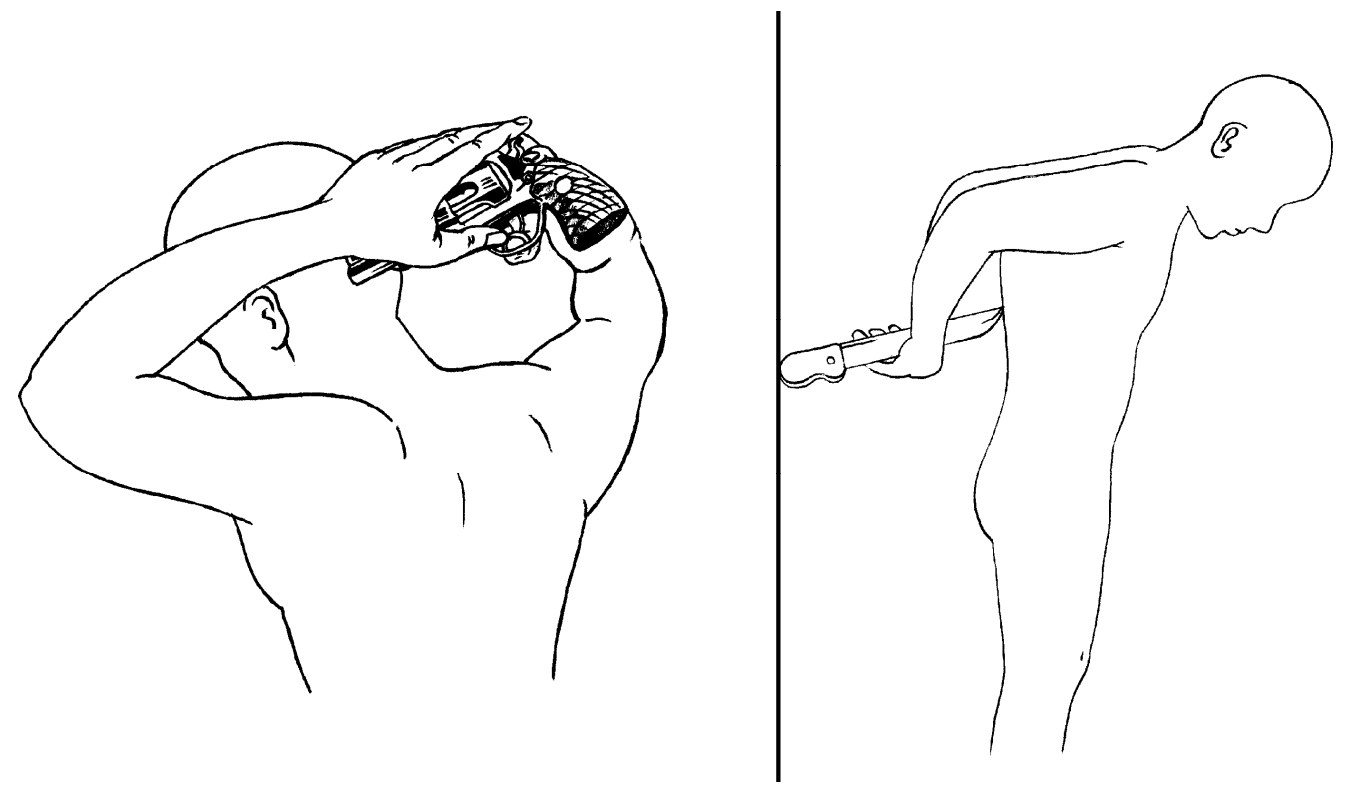

Figura 24 - Suicídios atípicos.

A simulação pode ser ainda praticada por familiares, na tentativa de ocultar o ocorrido visando receber o seguro de vida ou por outros motivos. O suicídio foi típico e há uma tentativa de alterar o local para dar-lhe a aparência de cenário de crime. Normalmente

\footnotetext{
${ }^{283}$ O Judaísmo, por exemplo, considera o suicídio tão grave quanto o assassinato. Para a doutrina Judaica, nenhum ser humano é dono do seu próprio corpo, pois ele não se fez sozinho, e quando alguém fere o corpo ou a alma comete-se uma ofensa contra a obra e a propriedade divinas. Por este motivo, alguns dos ritos tradicionalmente incluídos na cerimônia de sepultamento são negados ao suicida e ele é enterrado em uma parte do cemitério afastada dos demais túmulos, salvo se o fato ocorreu por comprovada perturbação mental (fonte: SOBEL, Henry I. Porquês do Judaísmo. Congregação Israelita Paulista. Disponível em: $<$ www.cipsp.org.br>. Acesso em: 10 jan. 2006).
} 
retiram a arma com que foi praticado o ato, suprimem o bilhete de despedida, introduzem sinais de violência no local ou mudam a posição do corpo.

Um perito atento e experimentado poderá com relativa facilidade identificar a simulação, que geralmente é levada a efeito por pessoas sem os conhecimentos técnicos necessários. A posição dos vestígios, a natureza e a orientação dos ferimentos, a correspondência destes com as vestes, a presença de resíduos provenientes do disparo nas mãos da vítima, o direcionamento das manchas de sangue e a disposição dos livores cadavéricos são apenas alguns dos elementos de que pode valer-se o experto para as suas conclusões.

\section{Simulação praticada por terceiros para encobrir o crime}

Esta é hipótese mais comum.

Embora no Brasil a violência e a criminalidade tenham ultrapassado em muito qualquer limite razoável, para uma sociedade que se pretende civilizada, e a maior parte dos delitos seja perpetrada com um grau de descaso pelos poderes públicos e uma brutalidade que não deixa qualquer dúvida sobre a etiologia do evento, ainda há casos em que o criminoso pode procurar mascarar o crime cometido para fazê-lo passar por morte natural, acidental ou suicídio.

Não se deve confundir a simulação com a destruição, subtração ou ocultação de cadáver (art. 211 do CP). Na ocultação, o autor do crime tenta livrar-se ou livrar terceiro da responsabilidade do ato praticado pela supressão do corpo da vítima, ou seja, não deseja que o cadáver seja descoberto. Os métodos são variados e vão desde a simples inumação, passando pelo espostejamento até a destruição pelo fogo ou mesmo a ingestão continuada dos restos mortais ${ }^{284}$.

\footnotetext{
${ }^{284}$ É o caso, por exemplo, de Armin Meiwes, conhecido como "der metzgermeister" (o açougueiro mestre) ou o "canibal de Rotemburgo", que combinou com Bernd Jürgen Armando Brandes, pela Internet, que iria assassiná-lo e comê-lo. Em março de 2001 Meiwes amputou o pênis de Brandes e os dois comeram o órgão genital juntos. Após Brandes perder a consciência pela hemorragia, Meiwes o esfaqueou no pescoço, pendurou o corpo em um gancho de açougueiro e começou a fatiá-lo, gravando o incidente em vídeo. $\mathrm{O}$ corpo foi mantido no freezer, de onde Meiwes retirou carne por meses e comeu em suas refeições diárias, chegando a ingerir cerca de $20 \mathrm{Kg}$ do cadáver. Quando a carne acabou, colocou um novo anúncio na internet e acabou sendo preso. Armin Meiwes foi condenado em 2004 a oito anos e meio de prisão. Posteriormente o caso foi apreciado novamente, porque a Suprema Corte alemã considerou que a Justiça foi muito branda e Meiwes foi condenado à prisão perpétua em 08 de maio de 2006 (CANIBAL alemão é condenado à prisão perpétua em última instância. Terra. Disponível em: $<$ http://noticias.terra.com.br/mundo/interna/0,,OI3280590-EI294,00-

Canibal+alemao+e+condenado+a+prisao+perpetua+em+ultima+instancia.html $>$. Acesso em: 10 maio 2006).
} 


\section{$\mathrm{CP}$}

Art. 211 - Destruir, subtrair ou ocultar cadáver ou parte dele:

Pena - reclusão, de 1 (um) a 3 (três) anos, e multa.

Na simulação, a idéia é a de que o corpo seja encontrado, mas de forma a induzir em erro a perícia, e, posteriormente, a justiça, para que entendam como irrelevante penal um fato que na verdade é criminoso.

Os meios utilizados para a simulação podem ser enquadrados em três grandes grupos:

a) os que colocam o corpo da vítima em situação na qual os ferimentos produzidos pelo autor são mascarados por outros de grandes proporções, ocorridos post mortem;

b) os que inovam a posição do corpo para dar a idéia de morte natural, acidental ou suicídio;

c) os que buscam a alteração do local na tentativa de suprimir ou disfarçar os vestígios indicativos da violência criminosa.

No primeiro caso, o autor, após matar a vítima por meios variados, atira o corpo pela janela de maneira a simular um suicídio por precipitação; coloca o cadáver sobre os trilhos de uma ferrovia ou no leito carroçável de uma via pública de grande movimento para que seja atropelado; provoca uma explosão ou um incêndio no local, etc.

No segundo caso, o agente lança o corpo em um rio para simular afogamento; dependura a vítima pelo pescoço, após estrangulá-la, para imitar um enforcamento; coloca a arma nas mãos do morto e outros.

Finalmente, pode o agente limpar as manchas de sangue do local, arrumar os móveis, retirar objetos quebrados, alinhar ou trocar as vestes do cadáver ${ }^{285}$, falsificar um bilhete de despedida, apagar impressões papilares, suprimir as armas e instrumentos do crime, etc.

\footnotetext{
${ }^{285}$ É o exemplo do rumoroso caso do homicídio do prefeito de Santo André (SP), Celso Daniel. Segundo a perícia, o corpo apresentava lesões na lateral do tórax, na parte interna do braço direito e na coxa direita, causados por estilhaços de projéteis de arma de fogo, mas as vestes com as quais o prefeito foi encontrado não apresentavam sinais compatíveis com os ferimentos encontrados. Isso indica que: ou o prefeito estava nu quando foi atingido pelos fragmentos de projéteis ou a sua roupa foi trocada após os disparos fatais (AS PROVAS da tortura. Revista Isto É, São Paulo, $\mathrm{n}^{\circ}$ 1.832, 25/01/06 - coluna: A semana. Terra. Disponível em: <www.terra.com.br/istoe/1892/1892_semana_02.htm>. Acesso em: 28 jan. 2006).
} 
Freqüentemente, tais métodos são mesclados na tentativa de tornar verossímil a simulação pretendida.

Dificilmente a simulação terá êxito se o perito for cuidadoso e sistemático em seus exames.

Ainda que o corpo apresente ferimentos de grandes proporções, a necropsia criteriosa poderá revelar sinais de lesões incompatíveis com o quadro geral. O exame do cadáver pelos Raios X e o diagnóstico diferencial entre as lesões produzidas em vida e depois da morte também serão elementos de grande valia para a determinação da real causa do óbito e da etiologia jurídica do evento.

O arranjo do local para dar a noção de irrelevante penal também não pode passar despercebido ao perito atento aos detalhes. Dificilmente uma pessoa leiga conseguirá construir um cenário artificial de suicídio ou acidente sem esquecer algum detalhe fundamental. A pressa em mascarar os vestígios e a tensão emocional pelo ato praticado certamente farão com que o autor esqueça à vista uma prova do crime praticado ${ }^{286}$.

Neste tópico, também assumem grande importância a análise criteriosa da disposição dos vestígios, a natureza e a orientação dos ferimentos, a correspondência destes com as vestes, o direcionamento das manchas de sangue e a disposição dos livores cadavéricos, fatores que fogem do controle do agente e que certamente permitirão a descoberta da simulação.

\subsection{Exame e levantamento técnico-pericial}

\subsubsection{Conceito e finalidades do exame e do levantamento técnico-pericial}

Inicialmente é preciso diferenciar o exame levado a efeito pelo perito, que é o momento de análise e apreensão intelectual de tudo que apresentar relação com o fato, do levantamento técnico pericial ou levantamento de local, que corresponde à técnica utilizada para preservar e perpetuar os indícios e vestígios materiais identificados.

\footnotetext{
${ }^{286}$ Certa feita, no Instituto de Criminalística de São Paulo, uma simulação de enforcamento foi descoberta porque os autores do homicídio, após estrangularem a vítima, colocaram o corpo com o rosto apoiado no chão antes de passar a corda pelo pescoço para dependurar o cadáver. Nesse ato, algumas partículas de terra ficaram presas na língua protrusa da vítima, despertando a suspeita nos peritos que examinaram o local.
} 
Antigamente denominado de inspeção ocular do local, o levantamento técnicopericial constitui, nas palavras de Eraldo Rabelo:

"O conjunto dos exames que se realizam diretamente no local da constatação do fato, visando à caracterização deste e à verificação, à interpretação, à perpetuação e à legalização, bem como à coleta, no mesmo, dos vestígios existentes da ocorrência, no que tiverem de útil para a elucidação e a prova dela e de sua autoria material." 287

Para Carlos Kehdy ${ }^{288}$ é a "reprodução do local por meio da descrição, do desenho ou da fotografia".

Unindo essas duas definições, poderíamos conceituar o levantamento técnicopericial como o conjunto de exames realizados no local, mediato e imediato, no corpo da vítima e nos instrumentos relacionados, por meio de descrição, fotografia, desenho, modelagem, técnicas de laboratório ou reprodução simulada dos fatos, com vistas a perpetuar e legalizar os indícios e vestígios materiais encontrados.

Seis são as finalidades do levantamento técnico-pericial:

a) a constatação material do fato, ou seja, verificar se existiu ou não uma infração penal. Saber se a hipótese considerada corresponde a um crime, a um acidente ou a um irrelevante penal (como o suicídio), sempre podendo, é claro, ter repercussão na esfera civil;

b) em se tratando de infração penal, caracterizá-la com relação à presença de circunstâncias agravantes ou atenuantes de cunho objetivo, ou seja, que produzam vestígios ou indícios materiais, como o meio empregado, ou documentos que apontem para o motivo do crime ${ }^{289}$;

c) pesquisar e colher elementos capazes de permitir a identificação do(s) autor(es) do fato;

d) pesquisar e colher elementos capazes de permitir a identificação da(s) vítima(s), quando desconhecida(s);

\footnotetext{
${ }^{287}$ RABELO, Eraldo. Curso de criminalística, cit., p. 49.

${ }^{288}$ KEHDY, Carlos. op. cit., p. 36.

${ }^{289}$ Embora o motivo do crime possa configurar uma circunstância de caráter subjetivo (motivo fútil ou torpe, por exemplo), o documento que comprova tal desiderato é um indício material.
} 
e) perpetuar os vestígios e indícios materiais encontrados a fim de permitir a sua utilização, a qualquer tempo, como elementos de prova, quer no processo penal, quer no processo civil;

e) legalizar e autenticar os elementos encontrados, conferindo a eles valor jurídico probante $^{290}$.

\subsubsection{Tipos de levantamento técnico-pericial}

Existem diversas maneiras de proceder ao levantamento de local, efetuadas em conjunto ou separadamente, conforme a requisição da autoridade requisitante. Todas elas, entretanto, podem ser classificadas, de acordo com o momento de sua realização, como iniciais ou complementares:

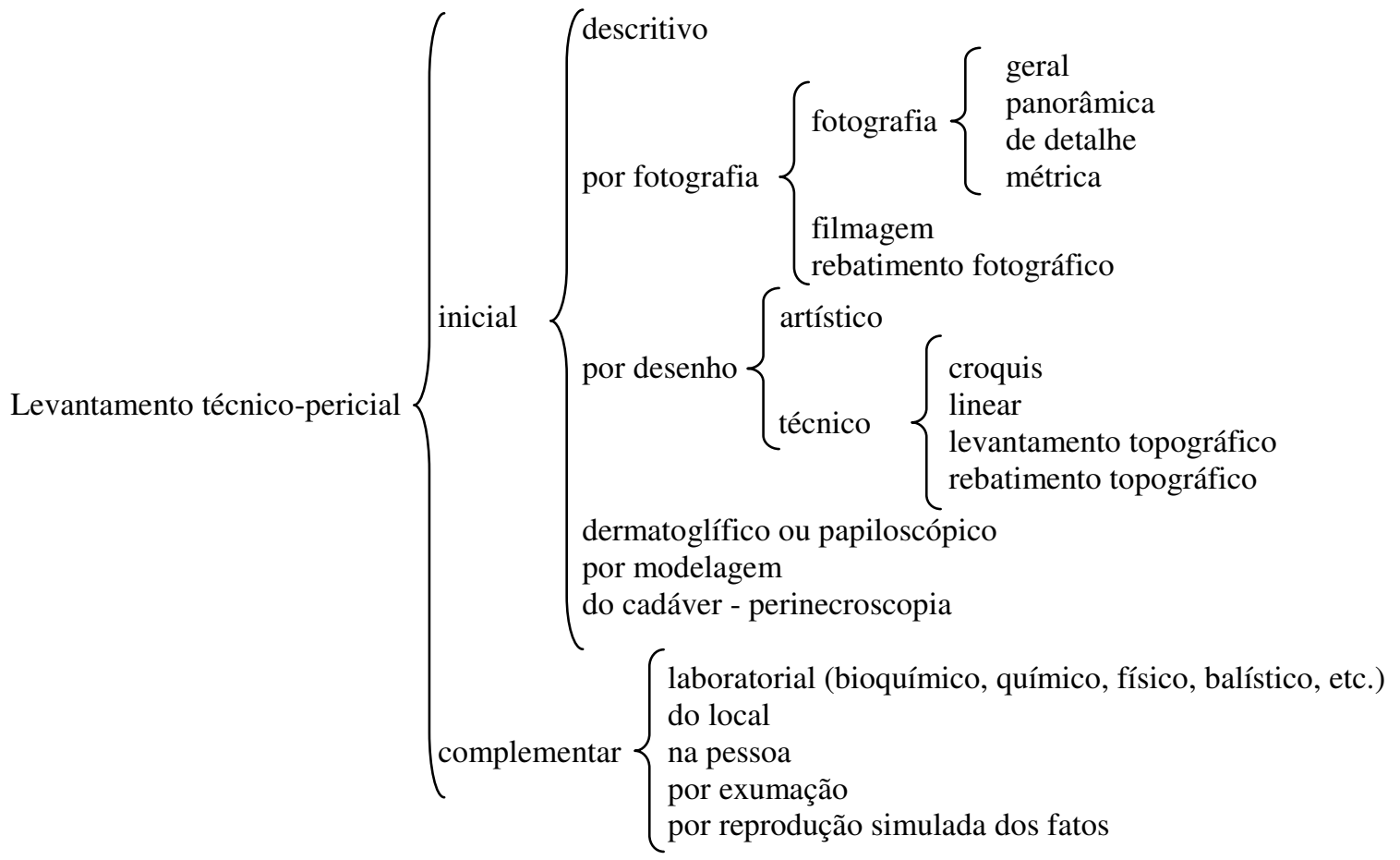

\footnotetext{
${ }^{290} \mathrm{O}$ próprio Eraldo Rabelo, a respeito da legalização dos indícios, em artigo publicado na Revista de Criminalística do Rio Grande do Sul lembra que "a prova datiloscópica, por exemplo, é cientificamente incontestável: não existem, absolutamente, argumentos capazes de invalidar uma identificação resultante de confronto datiloscópico. Mas, se não forem tomadas todas as precauções devidas, no sentido de autenticar, pelos meios hábeis em direito, o decalque de um datilograma colhido, por ocasião do levantamento, num local de crime, assegurando, deste modo, a legalização do indício, a prova de identidade, decorrente de posterior confronto, embora indiscutível, em relação ao indivíduo identificado, poderá ser inoperante relativamente ao fato, visto não eliminar a possibilidade de serem levantadas dúvidas quanto a tempo, lugar e circunstâncias em que se processou a colheita da impressão apresentada como proveniente do local da ocorrência" (RABELO, Eraldo. Contribuição ao estudo dos locais de crime. Revista de Criminalística do Rio Grande do Sul, ano 6, n 7, p. 59, 1968).
} 


\subsubsection{Levantamento descritivo}

A mais tradicional forma de levantamento de local, resumida no símbolo do Instituto de Criminalística pela frase latina "visum et repertum" é a descrição. Ultimados os seus trabalhos, seja qual for a finalidade da perícia ${ }^{291}$, o experto deve descrever o mais minuciosamente possível o local, os exames realizados e todos os achados de interesse.

Em algumas ocorrências, a descrição é o único registro da diligência. É forma processual indispensável, prescindindo qualquer outro meio.

A descrição, que pode ser subdividida entre as partes que normalmente compõem o auto ou laudo pericial ${ }^{292}$, engloba os seguintes assuntos:

a) antecedentes da perícia - um histórico sucinto da ocorrência, data e horário do fato, data e horário dos exames realizados, identificação da autoridade requisitante, finalidade da perícia, etc;

b) preservação do local - se o local estava ou não preservado e em que consistiu a violação. Que pessoas ou coisas foram introduzidas ou retiradas do cenário antes da chegada da equipe técnica;

c) outras informações e intercorrências - que possam afetar o resultado dos exames, como condições climáticas, presença de animais e outras;

c) a descrição do local propriamente dito (imediato e mediato) - o mais detalhadamente possível, com todos os vestígios de interesse, sua localização e importância;

d) a perinecroscopia - em se tratando de local em que ocorreu o evento morte e estando o corpo presente, é preciso fazer um relato da posição do corpo e de suas vestes, a análise dos livores cadavéricos, as manchas de sangue, ferimentos observados, marcas, cicatrizes, tatuagens e sinais particulares;

e) as armas e instrumentos do crime - suas posições em relação ao local e ao corpo da vítima;

f) os exames complementares realizados - no próprio local ou requisitados pelo perito ou pela autoridade para efetivação posterior (complementares);

\footnotetext{
${ }^{291}$ Ver item 1.5: "Classificação das perícias".

${ }^{292}$ Ver item 1.17.2: "Partes constitutivas do auto e do laudo pericial criminalístico".
} 
g) todos os objetos apreendidos elou entregues a terceiros - bem como a justificativa da destinação;

h) a técnica utilizada e as conclusões a que chegou o perito;

i) outras considerações necessárias.

A boa técnica de redação, entretanto, indica que o perito deve evitar fazer referência àquilo que não foi constatado. Não se recomenda, por exemplo, afirmar a inexistência de manchas de sangue, ou a ausência de vestígios produzidos pela ação de projéteis de arma de fogo, salvo se houver quesito expressamente formulado nesse sentido. Mesmo nessa última hipótese, a resposta do experto será a de que não foram observados tais vestígios. Jamais que eles não existem.

Esse cuidado é necessário porque é possível que tais elementos estejam presentes, mas não foram verificados pelo perito por desatenção, ou foram removidos pelo autor ou por terceiros. As constatações precisam ser positivas e objetivas. Tudo o que foi encontrado e observado merece descrição minuciosa. Nada mais.

\subsubsection{Levantamento por fotografia (fotografia judiciária)}

Velho ditado popular diz que uma imagem vale por mil palavras. Em termos de levantamento técnico-pericial a afirmação é apenas parcialmente verdadeira. A essência do laudo é a descrição e nada pode substituí-la. Todos os outros métodos são anexos. Servem para ilustrar e completar o trabalho pericial ${ }^{293}$, mas não para substituí-lo.

A fotografia judiciária, no dizer de Carlos Kehdy ${ }^{294}$, é “a reconstituição permanente do caso, permitindo futuras consultas". Inúmeras dúvidas, surgidas no decorrer do processo, somente puderam ser sanadas porque o perito teve o cuidado de documentar suas afirmações com fotografias do local $^{295}$.

Entre as suas finalidades destacam-se:

\footnotetext{
${ }^{293} \mathrm{~A}$ grande importância da fotografia reside na sua objetividade, principalmente em questões demasiadamente complexas para serem expressas por meio da palavra escrita.

${ }^{294}$ KEHDY, Carlos. op. cit., p. 48.

${ }^{295}$ No rumoroso "caso da Rua Cuba", por exemplo, uma das afirmações surgidas, depois do fato, foi a de que o ladrilho da borda da sacada do quarto em que foram encontrados os corpos das vítimas havia sido quebrado. Essa afirmação foi logo colocada por terra, pois o perito teve o cuidado de fotografar a aludida sacada, no dia imediatamente posterior ao evento, ainda íntegra.
} 
a) a fixação do estado do local do fato e dos vestígios e indícios materiais encontrados; e

b) a ilustração de ângulos técnicos de interesse, de maneira a complementar a descrição, orientar a conclusão e firmar a convicção da autoridade policial, do promotor de justiça e do magistrado sobre o caso.

O Código de Processo Penal trata da fotografia judiciária nos arts. 164, 165, 169 e 170, determinando a sua obrigatoriedade apenas se houver corpo no local (art. 164). O Código de Processo Civil trata da matéria no art. 429:

CPP

Art. 164. Os cadáveres serão sempre fotografados na posição em que forem encontrados, bem como, na medida possível, todas as lesões externas e vestígios deixados no local do crime.

Art. 165. Para representar as lesões encontradas no cadáver, os peritos, quando possível, juntarão ao laudo do exame provas fotográficas, esquemas ou desenhos, devidamente rubricados.

Art. 169. Para o efeito de exame do local onde houver sido praticada a infração, a autoridade providenciará imediatamente para que não se altere o estado das coisas até a chegada dos peritos, que poderão instruir seus laudos com fotografias, desenhos ou esquemas elucidativos.

Parágrafo único. Os peritos registrarão, no laudo, as alterações do estado das coisas e discutirão, no relatório, as consequiências dessas alterações na dinâmica dos fatos.

Art. 170. Nas perícias de laboratório, os peritos guardarão material suficiente para a eventualidade de nova perícia. Sempre que conveniente, os laudos serão ilustrados com provas fotográficas, ou microfotográficas, desenhos ou esquemas.

CPC

Art. 429. Para o desempenho de sua função, podem o perito e os assistentes técnicos utilizar-se de todos os meios necessários, ouvindo testemunhas, obtendo informações, solicitando documentos que estejam em poder da parte ou em repartições públicas, bem como instruir o laudo com plantas, desenhos, fotografias e outras quaisquer peças. (grifos nossos)

Quanto à abrangência, as fotografias dividem-se em:

a) geral - reproduz o local em sua integridade, com o maior número possível de elementos; 
b) panorâmica - nada mais é que a sucessão de fotografias gerais montadas, quando a área é por demais ampla para ser retratada em um único cromo ${ }^{296}$;

c) de detalhe - é a fotografia que procura individualizar um vestígio em particular. Os detalhes devem ser sempre tomados a partir de uma fotografia geral ou panorâmica, para que possam ser localizados. Como não se pode saber exatamente qual a distância, a fotografia de detalhe não serve para a mensuração do vestígio. Se isso for necessário devese utilizar a fotografia métrica;

d) métrica - ou em escala, é a fotografia acompanhada de escala e que permite a mensuração do vestígio considerado ${ }^{297}$.

A boa técnica recomenda que as fotografias sejam tiradas sempre do geral para o particular, procurando situar e individualizar todos os elementos de importância para a perícia.

No que toca ao número, devem ser tomadas tantas imagens quantas forem necessárias para a ilustração do trabalho pericial. Na prática, porém, por alegadas razões de contenção econômica, não é isso que vem ocorrendo.

Não raro, além de insuficientes em número ${ }^{298}$, as fotografias que ilustram os trabalhos periciais aparecem desfocadas, não abrangem a totalidade dos vestígios e não demonstram preocupação com o ângulo de tomada. As escalas, quando colocadas, não respeitam um alinhamento padrão e com freqüência são ilegíveis.

Atualmente, na época das imagens digitais, que reproduzem centenas de fotos praticamente sem custo algum, não mais se justifica esse tipo de desídia. É preciso que as autoridades públicas reconheçam a excelência da prova técnica e equipem os Institutos de Criminalística e Médico-Legal com equipamentos modernos e compatíveis com a importância da função.

\footnotetext{
${ }^{296}$ Atualmente existem programas de computador, como o Apple Quicktime, que fundem as imagens em visão panorâmica de $360^{\circ}$. Ver exemplos em: MCREADY, Peter. Disponível em: <http://petermccready.com/>. página do fotógrafo Peter McReady.

${ }^{297}$ A fotografia métrica foi idealizada inicialmente por Bertillon, que estabeleceu uma série de regras para a sua tomada. Atualmente a fotografia métrica se resume ao uso de escala.

${ }^{298}$ Uma equipe de peritos japoneses que recentemente visitou o Brasil mostrou-se impressionada com a pouca quantidade de fotos tiradas dos locais de crime.
} 


\section{Rebatimento fotográfico}

Similar ao rebatimento topográfico, o rebatimento fotográfico consiste na tomada de fotografia perpendicular ao piso, ao teto e às quatro paredes, objetivando a fixação e localização dos vestígios. Só é admissível em relação a ambientes internos e é técnica muito pouco utilizada no Brasil.

\section{Filmagem}

A filmagem, também de uso muito restrito no Brasil, pode ser eventualmente utilizada para o levantamento do local, mas apresenta algumas desvantagens:

a) custo elevado;

b) necessidade de equipamento próprio para sua produção e apreciação;

c) baixa qualidade de imagem quando comparada à fotografia, principalmente em se tratando de vídeo ou mesmo DVD ${ }^{299}$.

A única indicação que nos parece razoável é na reconstituição, pela possibilidade de transmitir à autoridade requisitante a espontaneidade dos participantes ao relatar suas versões. Mesmo assim, se for produzido, deverá sempre vir acompanhado do laudo respectivo.

Por outro lado, não se pode confundir o filme como objeto de prova, largamente utilizado em inúmeras ocorrências, com o filme produzido pelo perito como parte do levantamento técnico-pericial.

\subsubsection{Levantamento por desenho (topografia judiciária)}

Da mesma forma que a fotografia, o desenho é importante auxiliar no levantamento técnico-pericial e tem por objetivo suprir as deficiências da fotografia, particularmente quando é necessário um levantamento com precisão matemática ou para ilustrar a dinâmica de algum evento.

\footnotetext{
${ }^{299}$ Apenas para se ter uma idéia da baixa qualidade de imagem das filmadoras digitais, enquanto um filme tradicional de $35 \mathrm{~mm}$ apresenta uma resolução de aproximadamente 18 megapixels, o melhor vídeo digital não ultrapassa 1,3 megapixels.
} 
Mas, a utilidade do desenho não se resume a essas duas indicações principais. Como lembra Albani Reis ${ }^{300}$, o desenho pode também:

"Ser usado a título de ilustração nos laudos de exames de locais, sejam estes quais forem, mas também para ilustrar exames de materiais, peças, veículos, projéteis, armas, como para reconstituir quaisquer eventos, tais como acidentes de tráfego, de morte violenta, inclusive situações que a fotografia não pode ilustrar. Deve também ser usado para confeccionar gráficos, tabelas, organogramas e outros meios comunicativos, os quais enriquecerão grandemente o laudo pericial".

Entre as suas finalidades destacam-se:

a) a facilidade de localizar, com precisão, os indícios e vestígios encontrados;

b) o recurso de apontar determinados vestígios e suprimir outros de maneira a facilitar a compreensão de determinados fatos ou afirmações;

c) a opção de retratar a dinâmica de um fato sem o auxílio de filme;

d) a possibilidade de representar diferentes versões de um mesmo fato, de modo a permitir a comparação entre elas.

Entre as diversas espécies de perícia, o uso do desenho é mais comum nos acidentes de trânsito e nas reconstituições, exatamente porque permite representar a dinâmica do evento e a multiplicidade de versões. Entretanto, outras espécies de perícia, como a balística forense, por exemplo, podem perfeitamente utilizar os recursos gráficos como complementação.

O Código de Processo Penal trata dos desenhos e esquemas elucidativos nos arts. 165, 169 e 170, e o Código de Processo Civil dos desenhos e plantas no art. 429.

Os desenhos dividem-se basicamente em artísticos e técnicos.

O desenho artístico corresponde à representação de um objeto, pessoa ou acontecimento, de forma livre, com vistas a permitir sua identificação ou tornar compreensível uma característica técnica ${ }^{301}$, fato ou versão.

\footnotetext{
${ }^{300}$ REIS, Albani Borges dos. Desenho para criminalística e retrato falado. Campinas, SP: Millennium, 2003. p. 9.

${ }^{301}$ Como o funcionamento de uma arma de fogo, por exemplo. A maior parte dos desenhos utilizados neste trabalho apresenta uma concepção artística, cuja única preocupação é a de transmitir uma determinada idéia ou explicação. O retrato falado também é uma forma de desenho artístico que tem por finalidade a identificação de pessoas
} 
O desenho técnico é uma forma de linguagem gráfica que tem por objetivo representar, de forma precisa, lugares, objetos ou situações e que traz, em seu conteúdo, todas as informações relativas ao que representa, como, por exemplo, medidas, ângulos, cores, áreas, nomes, altitudes e, eventualmente, o material de que é composto o objeto considerado $^{302}$. Divide-se em:

a) croqui - é a ilustração sem escala do local e, à semelhança do desenho artístico, objetiva apenas a demonstração de um fato ou versão;

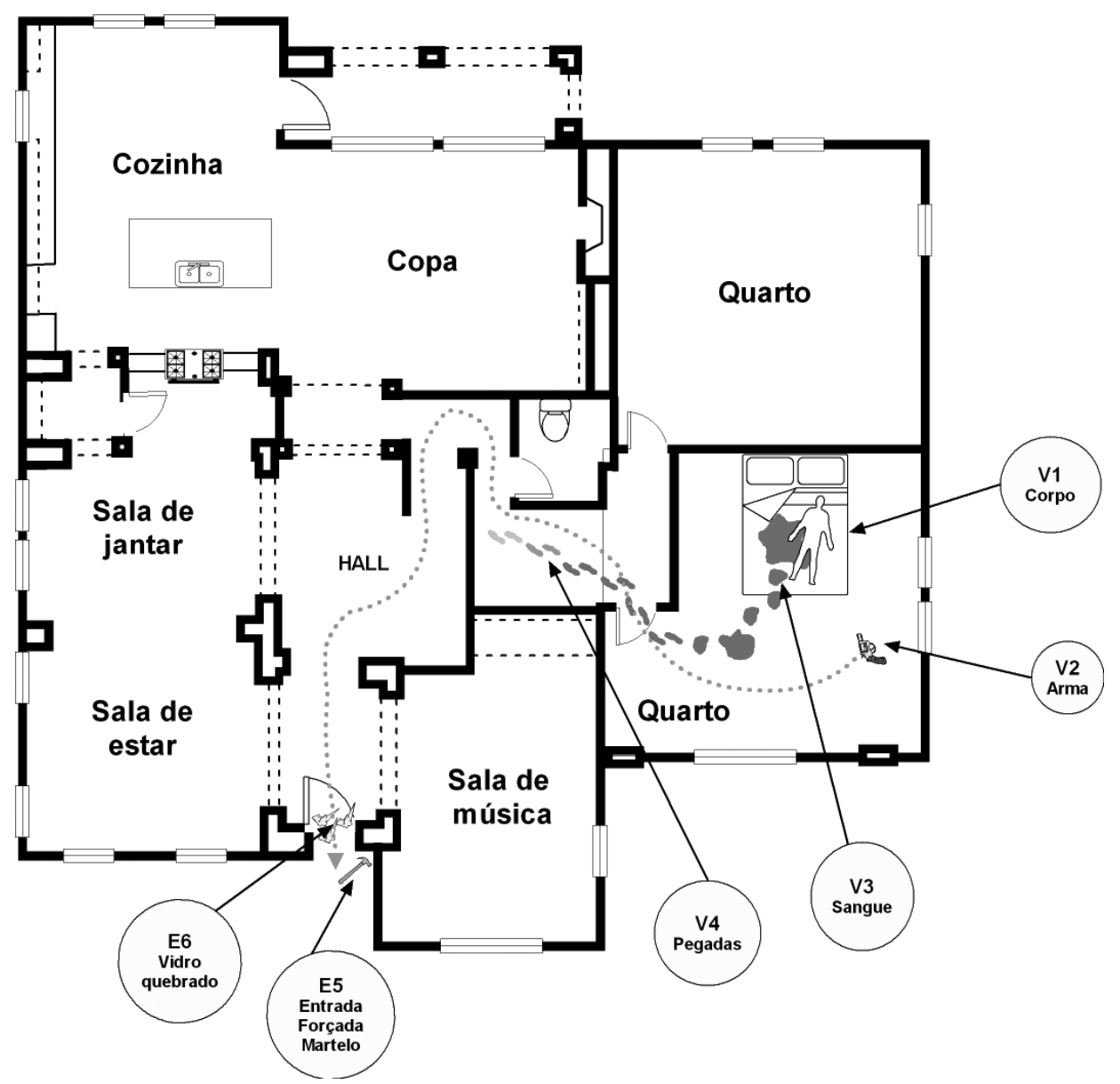

Figura 25 - Exemplo de croqui.

b) linear - é o desenho formado apenas por linhas, como gráficos e organogramas;

\footnotetext{
${ }^{302}$ REIS, Albani Borges dos. op. cit., p. 26.
} 


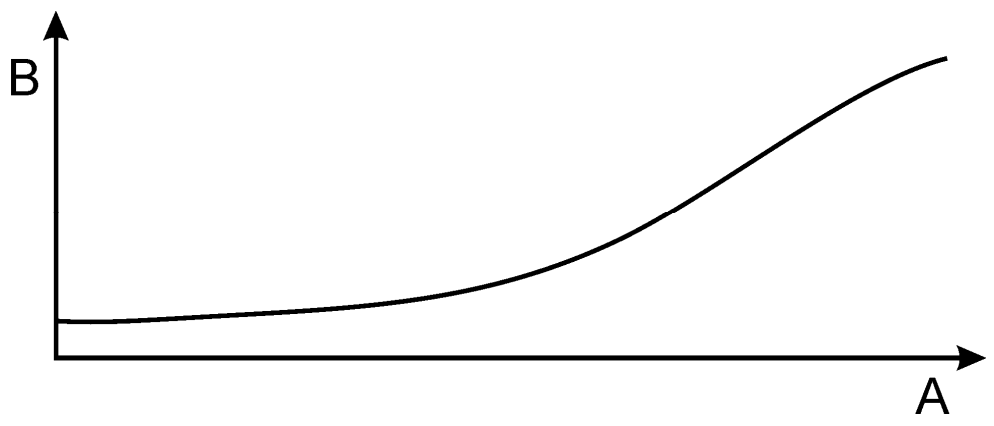

Figura 26 - Exemplo de desenho linear.

c) levantamento topográfico - é o desenho que busca representar no papel plano ou outro suporte, os acidentes geográficos de uma determinada área, com os acidentes e objetos colocados em sua superfície. É executado preferencialmente em escala e pode ser planimétrico (planta baixa), acompanhado ou não de um levantamento altimétrico (perfil), com a finalidade de assinalar as diferenças de nível do local;

d) rebatimento topográfico - também chamado de planimetria forense de Kenyeres é a ilustração rebatida do piso, do teto e das quatro paredes. Só é cabível em relação a ambientes internos e é muito pouco utilizado no Brasil. 


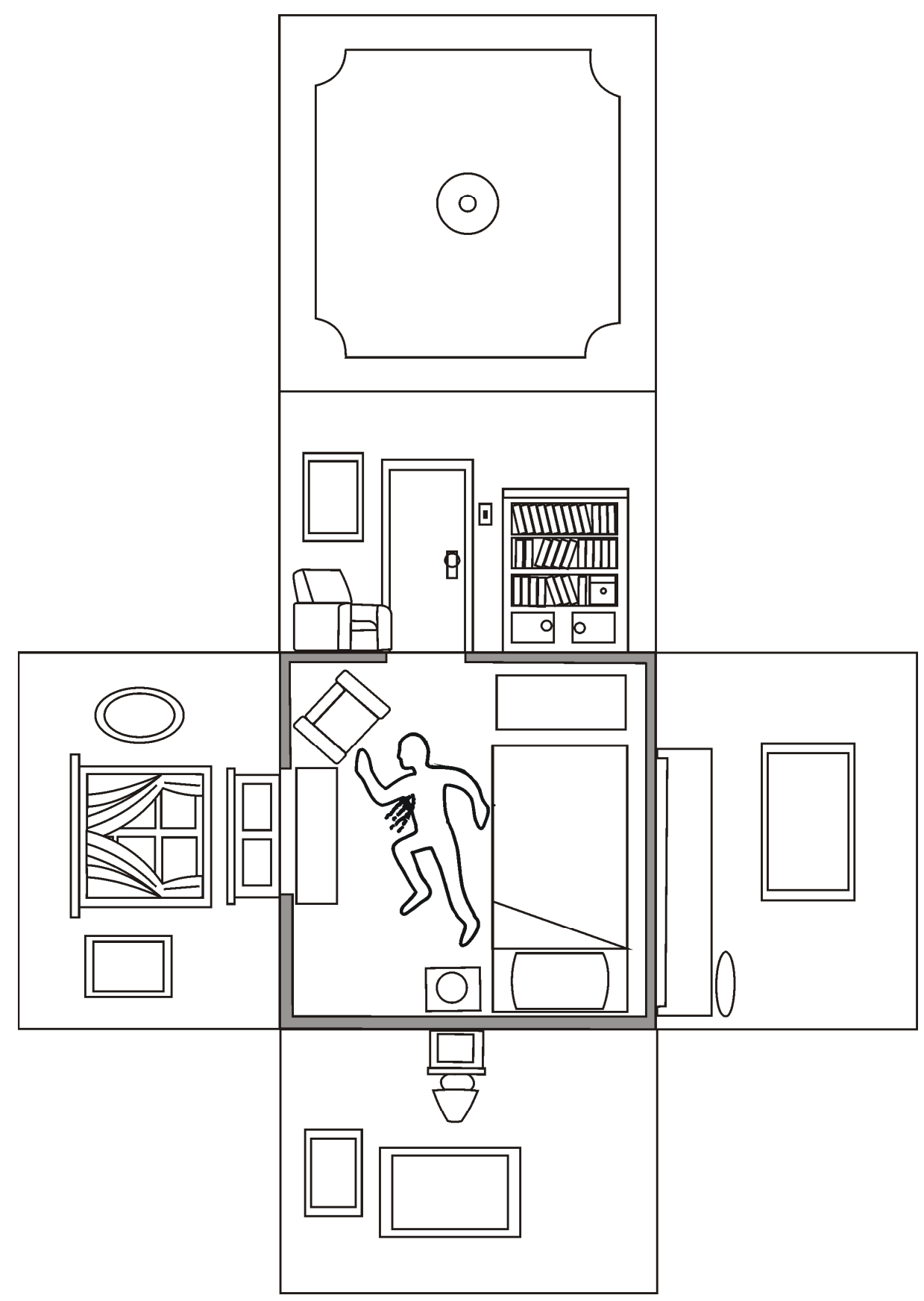

Figura 27 - Exemplo de rebatimento topográfico.

Atualmente há programas de computador que auxiliam o desenhista na tarefa de executar os desenhos técnicos como o CorelDraw ${ }^{303}$ ou o CAD (Computer Aided Design). Existem ainda alguns produtos específicos para a criminalística, como o SmartDraw Legal Solution, criado especificamente para a elaboração de esquemas de locais ${ }^{304}$.

\footnotetext{
${ }^{303} \mathrm{O}$ desenho acima (rebatimento topográfico) foi criado no CorelDraw.

${ }^{304} \mathrm{O}$ croqui utilizado como exemplo foi elaborado no programa SmartDraw 7.
} 


\subsubsection{Levantamento dermatoglífico (ou papiloscópico)}

O levantamento dermatoglífico, previsto nos arts. $6^{\circ}$, VIII, e 166 do Código de Processo Penal, nada mais é que o levantamento das impressões papilares (digitais, palmares e plantares) eventualmente deixadas pelo autor no local do fato.

\section{CPP}

Art. $6^{\circ}$. Logo que tiver conhecimento da prática da infração penal, a autoridade policial deverá:

VIII - ordenar a identificação do indiciado pelo processo datiloscópico, se possível, e fazer juntar aos autos sua folha de antecedentes;

Art. 166. Havendo dúvida sobre a identidade do cadáver exumado, proceder-se-á ao reconhecimento pelo Instituto de Identificação e Estatística ou repartição congênere ou pela inquirição de testemunhas, lavrando-se auto de reconhecimento e de identidade, no qual se descreverá o cadáver, com todos os sinais e indicações.

Parágrafo único. Em qualquer caso, serão arrecadados e autenticados todos os objetos encontrados, que possam ser úteis para a identificação do cadáver.

As características e as técnicas de levantamento dessa forma particular de impressão formam capítulo à parte, na antropologia médico-legal, devido à sua grande importância como meio de identificação e sua análise escapa aos objetivos deste trabalho.

\subsubsection{Levantamento por modelagem}

Já tivemos oportunidade de mencionar a modelagem como meio hábil ao levantamento de pegadas ${ }^{305}$ e marcas de pneumáticos ${ }^{306}$. A modelagem, porém, pode ser utilizada para levantamento e preservação de objetos (instrumentos, chaves, distintivos, etc.), assim como de quaisquer vestígios que tenham deixado marcas em alto ou baixo relevo, como impressões papilares moldadas e marcas produzidas por ferramentas, projéteis, unhas, dentes ou outros instrumentos.

\footnotetext{
${ }^{305}$ Ver item 2.6.4.5: "Marcas e impressões produzidas pelos pés descalços ou por solados (pegadas)".

${ }^{306}$ Ver item 2.6.5.4: "Marcas e sinais relacionados com veículos".
} 
A moldagem pode ser feita com qualquer material apropriado (gesso, cera, plasticina, parafina, etc.), desde que adequado à natureza do suporte e às características do vestígio considerado.

\subsubsection{Levantamento do cadáver (perinecroscopia)}

Denomina-se perinecroscopia ${ }^{307}$ o exame conjunto do cadáver e do local em que ele foi encontrado.

Embora o exame do corpo (necroscópico) seja atribuição do Instituto MédicoLegal, o exame do cadáver no local, sua posição em relação aos móveis e objetos, a situação das vestes, manchas, livores, hipóstases e ferimentos perceptíveis em uma inspeção externa, são da alçada do perito criminal.

O objetivo da perinecroscopia é a identificação do corpo e a coleta de informações de cunho médico-legal e criminalístico que possam auxiliar na determinação da etiologia jurídica do evento (homicídio, suicídio ou acidente) e da autoria.

Alguns vestígios, fundamentais para a reconstrução da dinâmica do evento, somente podem ser corretamente apreciados se analisados no conjunto das provas oferecidas pelo local, ficando prejudicados com o manuseio e a remoção do corpo, como o desalinho das vestes ou a presença de manchas de sangue e de outras substâncias ${ }^{308}$.

Seja o exemplo de uma pessoa morta com um único disparo, recebido quando estava deitada no chão e sem condições de defender-se (figura 28). O laudo médico-legal irá apontar os ferimentos, mas a circunstância do recurso que dificultou ou impossibilitou a defesa do ofendido apenas será comprovada pela afirmação de que a vítima, quando alvejada, não mais podia oferecer resistência. Esse fato somente poderá ser afirmado pelo perito de local, com o encontro do projétil incrustado no piso, em correspondência com o ferimento transfixante do corpo ${ }^{309}$.

\footnotetext{
${ }^{307}$ Do grego perí (em torno), skopeo (olhar) e nekrós (cadáver, morto).

${ }^{308}$ Ver itens 2.6.4.11: "Manchas e deposições de sangue" até 2.6.4.31: "Manchas de líquido amniótico".

${ }^{309}$ Ver item 3.8.3: "Divergência aparente entre peritos".
} 


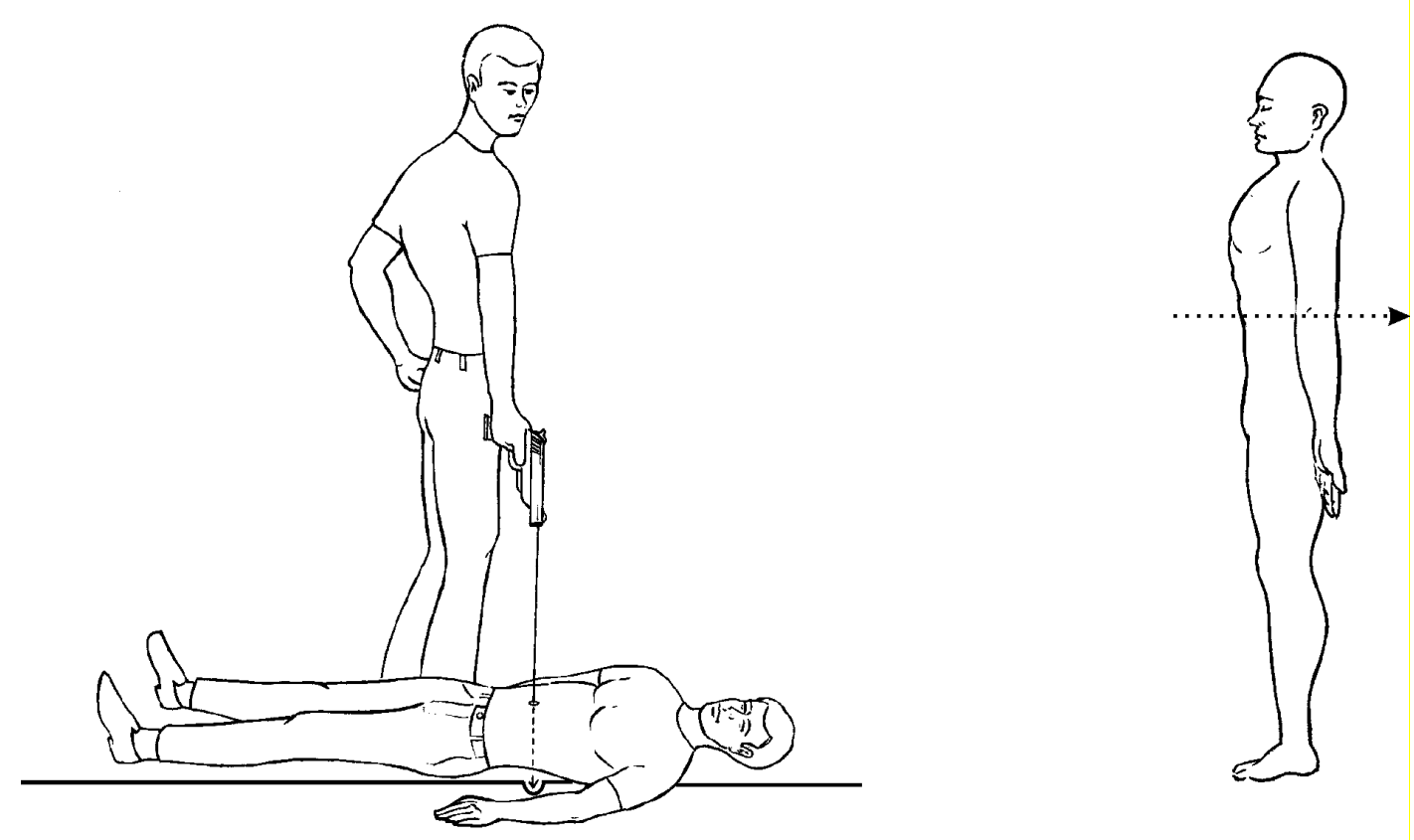

Figura 28 - Diferença entre a dinâmica do evento e a descrição do ferimento.

Em segundo lugar, como a necropsia, inclusive por determinação expressa do Código de Processo Penal (art. 162), na maioria das vezes não pode ser realizada de imediato, cabe ao perito de local a análise e a coleta dos principais elementos.

\section{CPP}

Art. 162. A autópsia será feita pelo menos 6 (seis) horas depois do óbito, salvo se os peritos, pela evidência dos sinais de morte, julgarem que possa ser feita antes daquele prazo, o que declararão no auto.

Parágrafo único. Nos casos de morte violenta, bastará o simples exame externo do cadáver, quando não houver infração penal que apurar, ou quando as lesões externas permitirem precisar a causa da morte e não houver necessidade de exame interno para a verificação de alguma circunstância relevante.

Alguns fenômenos cadavéricos consecutivos, como a disposição dos livores ou resfriamento do corpo, têm início logo após a morte e devem ser observados no local, pois certamente serão alterados pelo transporte ao Instituto Médico-Legal.

Além disso, como o cadáver é geralmente apresentado despido ao médico-legista, todos os vestígios relacionados com as vestes ${ }^{310}$ precisam ser apreciados no local, em

${ }^{310}$ Ver item 2.6.4.40: "Peças de vestuário e acessórios". 
especial os resíduos provenientes do disparo de arma de fogo, importantíssimos para a determinação da distância do atirador.

Resumindo, de uma maneira geral o exame perinecroscópico compreende:

a) a análise da posição do cadáver intocado - a primeira tarefa do perito é analisar o corpo da maneira em que este foi encontrado e a sua vinculação com o ambiente, assinalando a distância em relação a determinados objetos ou pontos de referência relacionados com o evento;

b) a constatação do estado e da disposição das vestes - em seguida, o técnico, ainda sem tocar o corpo, irá verificar se as roupas trajadas pela vítima estão em alinho ou desalinho, se indicam luta, se apresentam soluções de continuidade ${ }^{311}$, se ostentam manchas de sangue ou outras substâncias, etc.;

c) a verificação da presença de arma e a posição desta em relação ao corpo - o que se torna particularmente importante nos casos de suicídio, pois o experto precisará determinar se a vítima tinha ou não condições de pôr termo à própria vida como o local parece indicar;

d) a verificação da existência de manchas ou sinais orientados em direção ao cadáver - ou que partam dele em outra direção e que possam indicar inovação em sua posição;

e) a pesquisa de eventuais estigmas profissionais - marcas deixadas no corpo ou nas vestes pelo exercício contínuo de uma profissão. Os estigmas profissionais podem ser de grande valia se for necessária a identificação da vítima;

f) a coleta de material das mãos da vítima para exame residuográfico - se o material não for colhido na hora, o perito deve proteger as mãos do cadáver, colocando-as, se possível, dentro de sacos de papel ou plástico ${ }^{312}$ perfeitamente limpos.

g) a coleta de valores, papéis, documentos e demais pertences da vítima - o que deve ser feito apenas depois de todo o exame inicial e somente após o perito se certificar que o manuseio das vestes não irá destruir nenhum vestígio. De qualquer modo, tal manuseio precisa ser feito com as mãos guarnecidas por luvas de látex e com extrema cautela;

\footnotetext{
${ }^{311}$ As soluções de continuidade devem ser sempre cotejadas com os ferimentos existentes no corpo.

${ }^{312}$ Montiel Sosa (op. cit., V III, p. 91) recomenda sacos de papel, porquanto os de plástico podem gerar calor ou umidade.
} 
h) a procura por vestígios encobertos pelo corpo - ao mover o cadáver, o perito precisa ter cuidado e atenção para não destruir ou modificar vestígios eventualmente existentes debaixo ou atrás da vítima;

i) a retirada e o exame das vestes - o que deve ser feito com extrema cautela, preferencialmente sem que a roupa seja cortada. Se isso for inevitável, jamais cortar o tecido em região onde exista um vestígio a ser preservado. Nos crimes sexuais é necessário prestar especial atenção às roupas íntimas e às peças que ficam debaixo do corpo, pela possibilidade do encontro de manchas de esperma;

j) exame externo do cadáver - embora o exame do corpo seja da alçada do médico-legista, é imprescindível que o perito proceda a um exame externo, anotando a temperatura do corpo, distribuição dos livores, ferimentos, lesões, deformidades, sinais particulares, tatuagens, cicatrizes e outros elementos que possam ser úteis para o deslinde do caso. Nos crimes sexuais, é recomendável a varredura dos pêlos pubianos da vítima à procura de pêlos do agressor. As unhas do cadáver precisam ser vistoriadas em busca de fragmentos de pele do autor.

Finda a perinecroscopia e o exame do local, é necessário que o perito comunique ao médico-legista, por qualquer meio, os achados incomuns, como venenos, substâncias químicas, ferimentos atípicos e outras circunstâncias que possam auxiliar na realização da necropsia e na coleta de exames necessários para o esclarecimento do caso.

\subsubsection{Levantamento complementar laboratorial}

Todos os materiais encontrados no local, orgânicos ou não, precisam ser recolhidos de modo apropriado e encaminhados aos laboratórios respectivos para análise.

Reportamo-nos aos tópicos anteriores em que alguns dos possíveis exames laboratoriais foram mencionados.

Convém lembrar que exatamente no campo das provas laboratoriais é que houve maior evolução. A identificação pelo DNA, os kits padronizados, as novas técnicas de análise orgânica (cromatografia, espectrofotometria e espectrometria de massa) e inorgânica (espectrofotometria de absorção atômica, análise por ativação neutrônica e difração de raios X) e a evolução da microscopia (convencional e eletrônica) são alguns 
dos instrumentos à disposição do perito diligente que permitem a extração de conclusões antes imaginadas apenas na esfera da ficção.

Nenhuma dessas tecnologias, entretanto, dispensa o acurado e minucioso exame de local, assim como uma confiável cadeia de custódia.

\subsubsection{Levantamento complementar do local}

É possível que após a realização da perícia inicial seja necessária a efetivação de outra, complementar. Isso pode ocorrer em três situações distintas:

a) porque o próprio perito, ao redigir o seu relatório, encontrou necessidade de retornar ao local para esclarecer pontos duvidosos;

b) porque o perito, depois de entregar seu relatório, questionou as próprias conclusões e decidiu pela necessidade de um reexame; e

c) porque houve requisição do exame complementar.

A primeira situação não constitui propriamente uma perícia complementar, mas sim a continuidade do exame. Embora as perícias, em regra, sejam rápidas, não superando o espaço de um dia, há casos complexos que demandam tempo mais prolongado. Nessas hipóteses o perito pode e deve retornar ao local quantas vezes entender necessário, complementando o trabalho inicial.

A segunda ocorrência é mais rara. Percebendo, depois de apresentar suas conclusões, que incorreu em erro ou omissão capaz de macular seu trabalho, o técnico decide, sponte sua, elaborar novo relatório. Embora o Código de Processo seja omisso, entendemos que o perito pode e deve realizar o segundo exame, comunicando previamente o fato à autoridade requisitante.

A terceira e mais comum situação é aquela contemplada pelo art. 168 do Código de Processo Penal e refere-se à perícia falha, na qual o experto, por erro ou inaptidão, incide em inépcia, perplexidade, contradição ou deficiência.

CPP

Art. 168. Em caso de lesões corporais, se o primeiro exame pericial tiver sido incompleto, proceder-se-á a exame complementar por determinação da autoridade policial ou judiciária, de ofício, ou a 
requerimento do Ministério Público, do ofendido ou do acusado, ou de seu defensor.

$\S 1^{\circ}$ No exame complementar, os peritos terão presente o auto de corpo de delito, a fim de suprir-lhe a deficiência ou retificá-lo.

$\S 2^{\circ}$ Se o exame tiver por fim precisar a classificação do delito no art. $129, \S 1^{\circ}$, I, do Código Penal, deverá ser feito logo que decorra o prazo de 30 (trinta) dias, contado da data do crime.

$\S 3^{\circ}$ A falta de exame complementar poderá ser suprida pela prova testemunhal.

\subsubsection{Levantamento complementar na pessoa}

As perícias que têm por objeto a pessoa são da alçada do Instituto Médico-Legal e, da mesma forma, podem exigir a realização de exames complementares. Valem as considerações feitas no item anterior com uma única observação.

Reza o $\S 2^{\circ}$ do art. 168 do Código de Processo Penal, que "se o exame tiver por fim precisar a classificação do delito no art. 129, § $1^{\circ}$, I, do Código Penal, deverá ser feito logo que decorra o prazo de 30 (trinta) dias, contado da data do crime".

Trata-se de exame complementar legal e obrigatório, exigido para comprovação da gravidade da lesão corporal por incapacidade para as ocupações habituais, por mais de 30 dias.

A perícia, por expressa disposição legal, precisa ser realizada exatos 30 dias após $o$ crime. Um engano muito comum, cometido por médicos-legistas, é o de agendar a perícia complementar 30 dias depois do exame inicial, ou seja, além do $31^{\circ}$ dia. É preciso ter em mente que nem sempre a vítima de uma agressão comparece ao IML na data da ocorrência. O mais comum, aliás, é que essa visita ocorra dias depois. Assim, se a segunda perícia for agendada com base na primeira e não na data do crime, as lesões podem desaparecer, fazendo com que o médico não conclua pela presença da qualificadora.

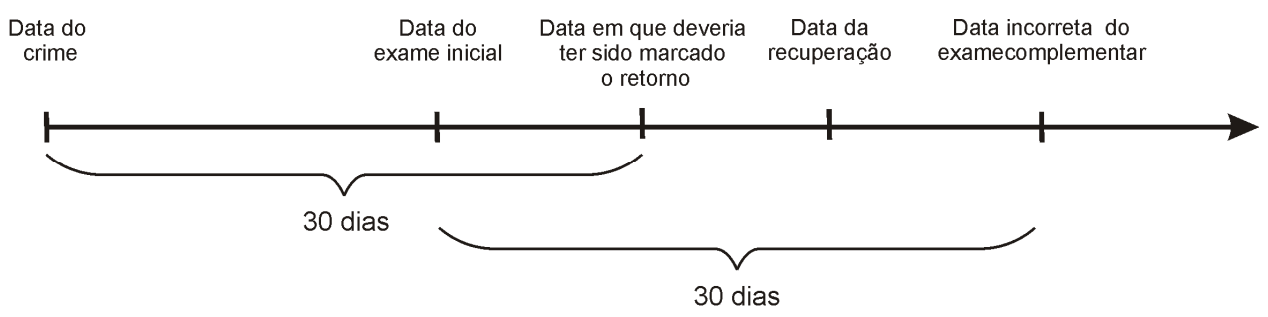


Por outro lado, se mesmo realizada de forma extemporânea a perícia conseguir comprovar a incapacidade para as ocupações habituais por lapso superior ao estipulado no $\S 2^{\circ}$ do art. 168 do Código de Processo Penal, a conclusão será válida e a qualificadora comprovada. Assim têm entendido nossos Tribunais:

\begin{abstract}
"Embora realizado muito tempo depois o exame complementar, é de se ponderar que o que pretende a lei penal é que se estabeleça o nexo causal entre a conduta delituosa e seu resultado; e isto ficou patente nos autos, eis que a vítima, por ocasião do referido exame, ainda deambulava com auxílio de muletas" (TJSP - AP - Rel. Sinésio de Souza - RJTJSP 131/484).

"Não se pode rejeitar o exame complementar só por ter sido realizado alguns dias após o $31^{\circ}$ dia. Do contrário, no interior do Estado, nos lugares mais atrasados, onde quase tudo depende de providências de fora, dificilmente se apuraria, na maioria dos casos, a gravidade da lesão" (RT 398/385).
\end{abstract}

\title{
2.7.2.10. Levantamento complementar por exumação
}

Uma vez inumado o cadáver, a inviolabilidade do sepulcro se impõe por motivos de ordem higiênica e razões de cunho religioso. O normal é não mais retornar ao corpo. Há situações, entretanto, em que, para a realização de perícias civis ou criminais torna-se necessária a perturbação da paz perpétua para esclarecimento de alguma questão relacionada ao óbito ou à sucessão do falecido. Nestes casos estaremos diante de exumações.

\subsubsection{Reprodução simulada dos fatos}

A reprodução simulada dos fatos ou simplesmente reconstituição é um tipo de exame de corpo de delito complementar, retrospectivo e facultativo, cuja finalidade é verificar a possibilidade de um determinado fato, de interesse jurídico-penal ter ocorrido ou não segundo versão apresentada pela(s) vítima(s), testemunha(s) ou indiciado(s).

A previsão legal está no art. $7^{\circ}$ do Código de Processo Penal e art. 13, parágrafo único do Código de Processo Penal Militar: 


\section{CPP}

Art. $7^{\circ}$ Para verificar a possibilidade de haver a infração sido praticada de determinado modo, a autoridade policial poderá proceder à reprodução simulada dos fatos, desde que esta não contrarie a moralidade ou a ordem pública.

\section{CPPM}

Art. 13...

Parágrafo único. Para verificar a possibilidade de haver sido a infração praticada de determinado modo, o encarregado do inquérito poderá proceder à reprodução simulada dos fatos, desde que esta não contrarie a moralidade ou a ordem pública, nem atente contra a hierarquia ou a disciplina militar.

Deve ser requisitada pela autoridade apenas nos casos em que existam dúvidas a respeito da forma ou circunstâncias como o fato se desenrolou, ou seja, qual foi o comportamento dos sujeitos ativos da infração penal considerada em relação às vítimas e eventuais testemunhas.

É importante ter em mente que a reconstituição é voluntária e que nem a autoridade policial, nem a judiciária podem forçar as partes a figurar na reconstituição ou representar as fases do delito.

\section{Reconstituição sobre depoimentos}

Como nem sempre o autor do fato concorda em participar da reprodução dos fatos, até porque tem medo de ser incriminado de forma indelével, é comum aportarem no Instituto de Criminalística requisições para a realização de "reconstituição sobre depoimento existente nos autos".

$\mathrm{Na}$ maioria das vezes o Instituto de Criminalística nega-se a atender ao pedido, argumentando que a reconstituição reclama a presença física das partes envolvidas, podendo, no máximo, a vítima e um ou outro participante ser substituído por terceiro convidado a atuar.

Em que pese ao fato de uma reprodução extraída unicamente de uma versão escrita ter valor muito questionável, a negativa sistemática do Instituto de Criminalística em atender à requisição não tem razão de ser. 
Em primeiro lugar, o Código de Processo Penal, em seu art. $7^{\circ}$, não exige a presença das partes, limitando-se a informar que a autoridade policial poderá proceder à reprodução simulada dos fatos, desde que esta não contrarie a moralidade ou a ordem pública, únicas vedações expressas à perícia.

Em segundo lugar, se é bem verdade que inúmeros fatores de importância para a perícia, como a posição exata das partes, a localização de móveis e objetos ou a percepção das nuances psicológicas dos participantes não poderão ser considerados pelo perito, por outro lado, será perfeitamente possível atender o pedido com relação a dados objetivos e inquestionáveis da versão apresentada.

A maior parte dessas requisições, na verdade, não objetiva uma reconstituição propriamente dita, mas sim um exame complementar que reclama, por exemplo, o tempo de realização de um determinado trajeto, a posição relativa dos ferimentos observados no corpo da vítima, a possibilidade ou não de um evento ter ocorrido segundo uma determinada versão. Todas elas questões que podem e devem ser apreciadas pela perícia.

Esse impasse absurdo, que já se estende por anos, ilustra bem aquilo que foi apontado no início deste trabalho, ou seja, a falta absoluta de canais eficientes de comunicação entre os órgãos encarregados de aplicar a justiça e aqueles aos quais cabe a realização dos exames periciais.

A autoridade precisa delimitar o âmbito da perícia requisitada, fixar os pontos controversos e elaborar quesitos objetivos e pertinentes. $\mathrm{O}$ técnico deve entender que não pode simplesmente deixar de proceder ao exame pedido, mas procurar esclarecer qual o seu verdadeiro objetivo, explicando de maneira clara e precisa os pontos que podem ser abordados e os que não podem.

A melhor solução para o caso, como sempre, é o contato direto entre a autoridade requisitante e o perito.

\section{Finalidades da reconstituição}

São finalidades da reprodução simulada dos fatos:

a) verificar as reações das partes quando confrontadas com o local do crime e suas circunstâncias; 
b) evitar a errônea responsabilização penal decorrente de confissão espontânea com a finalidade de isentar o verdadeiro autor dos fatos;

c) evitar a errônea responsabilização penal decorrente de confissão obtida por coação física ou psicológica;

d) comprovar, enfim, a viabilidade ou a impossibilidade de os fatos terem ocorrido de uma determinada forma, segundo versões apresentadas; e

e) contribuir para a evocação dos fatos, pela teoria da associação de estímulos ${ }^{313}$.

Em razão de suas finalidades, o perito precisa buscar, por todos os meios, os recursos necessários para prover o laudo pericial do imprescindível conteúdo técnico.

$\mathrm{Na}$ falta de elementos materiais, o experto não deve improvisar ou realizar uma reconstituição falha. Ao contrário, precisa solicitar à autoridade requisitante ${ }^{314}$ os meios indispensáveis para orientar os trabalhos e formar sua convicção sobre a ocorrência que, tecnicamente, deverá dirigir.

\section{Vedações legais}

Não são todas as infrações penais que permitem a reconstituição. $\mathrm{O}$ art. $7^{\circ}$ do Código de Processo Penal veda a realização da reprodução simulada nos casos em que a sua realização possa atingir a moralidade ou a ordem pública. Da mesma forma, o Código de Processo Penal Militar, para os delitos militares próprios, repete as proibições anteriores e acrescenta a hipótese de atentar contra a hierarquia ou a disciplina militar.

O conceito de moralidade pública para efeitos penais abrange não apenas os bons costumes, protegidos pela lei penal, como também as normas de conveniência ou de respeito próprio, que, embora não sejam previstas pelo Direito positivo, obrigam em consciência.

\footnotetext{
${ }^{313}$ A teoria associacionista, comportamentalista ou behaviorista atribuiu ao ambiente, através da associação de idéias, a constituição das características humanas e privilegia a experiência como fonte de formação de hábitos e comportamentos. O modelo associacionista, que teve início com a teoria da associação de palavras de Sigmund Freud, evoluiu para a teoria da associação entre estímulos, de Ivan Petrovich Pavlov; para a teoria da associação entre estímulo e resposta de John Broadus Watson e para a teoria da associação entre resposta e reforço com Burrhus Frederic Skinner, todas generalizadas por Harald Höffding sob o nome de lei do interesse. Segundo ele, quando um elemento de nossa experiência se produz pela segunda vez (no caso a reprodução simulada de um crime), o conjunto dos estados de consciência que a ele estavam associados se reproduz conjuntamente (DORON, Roland; PAROT, Françoise. Dicionário de psicologia. São Paulo: Ática, 1998, verbete: “associacionismo”, p. 87).

${ }^{314}$ Policial, policial militar, judiciária ou membro do Ministério Público.
} 
Não é possível realizar reconstituições de crimes contra a liberdade sexual como "estupro" (art. 213 do CP) $)^{315}$ ou "atentado violento ao pudor" (art. 214 do CP). Da mesma forma, não se recomenda a sua realização em alguns dos crimes contra o sentimento religioso e respeito aos mortos, como "ultraje a culto e impedimento ou perturbação de ato a ele relativo" (art. 208 do $\mathrm{CP}$ ) ou "vilipêndio a cadáver" (art. 212 do CP). Em todas essas hipóteses, eventuais dúvidas devem ser sanadas por outros meios de prova, jamais a reprodução simulada.

A possibilidade de turbação da ordem pública, entendida como o "conjunto de normas jurídicas, políticas e morais cuja violação perturba a convivência harmônica da sociedade" ${ }^{316}$, também não indica a realização da reconstituição.

São geralmente casos que causaram grande comoção pública, e a cautela recomenda pouca exposição a fim de evitar risco aos participantes da reprodução ${ }^{317}$.

Na Justiça Penal Militar, especificamente, impõe-se, ainda, o respeito às regras de hierarquia e disciplina, regras que, juntamente com o companheirismo, compõem os princípios norteadores da função militar.

A reconstituição de alguns crimes militares próprios, como os de "desrespeito a superior e a símbolo nacional ou à farda" (arts. 160 a 162 do CPM), se levada a efeito em um quartel, pode ser desaconselhável.

Assim, também, a reprodução de delitos que atentem contra a disciplina militar, como o de "violência contra superior" (art. 157 do CPM), deve ser evitada.

\section{Etapas da reconstituição}

Antes de proceder à reconstituição o perito deve $\mathrm{e}^{318}$ :

\footnotetext{
${ }^{315}$ Lamentavelmente, o preceito legal não é seguido à risca. Em 18 de fevereiro do corrente ano, a Polícia Civil de São Paulo procedeu à inconveniente e desnecessária reconstituição de um caso de estupro ocorrido em 2006 no interior do Hospital Universitário de Taubaté. Embora a conclusão da autoridade tenha sido no sentido da utilidade da reconstituição, a prática deve ser evitada pelo dano psíquico que pode causar à vítima ou mesmo pela expressa vedação legal (POLÍCIA reconstitui estupro em hospital de SP. Terra. Disponível em: <http://noticias.terra.com.br/brasil/interna/0,,OI2470594-EI5030,00.html>. Acesso em: 21 out. 2008).

${ }^{316}$ ZARZUELA, José Lopes. Temas fundamentais de criminalística, cit., p. 174.

${ }^{317}$ A hipótese também não é observada pela Polícia Civil, que sempre procura realizar reconstituições em casos de repercussão, diligência que, com freqüência, se mostra absolutamente inútil.

${ }^{318}$ Alguns autores entendem que essas providências são dispensáveis em relação ao perito que procedeu ao levantamento do local. Com o devido respeito, mesmo tendo realizado o exame inicial, o técnico precisa inteirar-se de todos os detalhes do inquérito ou do processo antes de realizar a perícia.
} 
a) estudar minuciosamente os autos do inquérito ou processo, particularmente no que toca ao interrogatório, depoimentos da vítima e testemunhas e todos os laudos existentes;

b) ouvir as partes presentes;

c) verificar se existem condições apropriadas de segurança, solicitando da autoridade requisitante que providencie as medidas necessárias para garantir a tranqüilidade do exame. Isso será particularmente importante nos casos em que o clamor púbico contra o crime cometido recomenda cautela ou quando o autor do fato apresenta periculosidade ou está ligado a facções do crime organizado ${ }^{319}$;

d) isolar e identificar claramente a área em que deverá ocorrer a reconstituição de modo a evitar acidentes ${ }^{320}$;

e) verificar se houve alteração física da área entre a data do fato e a data da reconstituição, o que pode ser feito pelo estudo do laudo de local e por informações obtidas no preparo da reconstituição.

Inteirado do conteúdo dos autos, particularmente das versões apresentadas pelas pessoas que irão integrar a reconstituição, o perito deve:

f) fixar o número de versões que serão apresentadas, verificando qual deve ser realizada primeiro e atentando para o fato de que a cada uma delas deve corresponder uma seqüência própria;

g) antes de iniciar a etapa de representação das versões, fotografar todos os participantes, preferencialmente em uma tomada coletiva, para poder identificá-los no relatório que será produzido;

h) à medida que as versões forem sendo representadas, registrar os passos principais por fotografia, de acordo com a seqüência indicada pelos participantes, ainda que não obedeça a uma lógica formal ${ }^{321}$. As imagens devem ser abrangentes e sempre tomadas em ângulo que favoreça a explanação; e

\footnotetext{
${ }^{319}$ Às vezes a reconstituição abrange locais públicos ou externos. Como para se realizar uma boa reprodução dos fatos é preciso dar ao autor certa liberdade, para que possa atuar com espontaneidade, é preciso tomar todas as cautelas para que não ocorra resgate ou fuga.

${ }^{320}$ Certa oportunidade, ao realizar uma reconstituição de homicídio, a equipe do Instituto de Criminalística de São Paulo foi surpreendida por policiais militares que, pensando tratar-se de um crime real em andamento, irromperam no local de armas em punho dando voz de prisão a todos os participantes.

${ }^{321}$ Não se pode esquecer que uma das principais finalidades da reconstituição é a de comprovar uma inverdade.
} 
i) sendo necessário, determinar a elaboração de desenhos esquemáticos para melhor ilustrar a dinâmica do evento ${ }^{322}$.

\subsubsection{Alguns locais que merecem especial atenção}

Alguns casos reclamam atenção especial do perito, quer pela maior possibilidade de simulação, quer pelo estado de decomposição ou a extensão das lesões observadas no corpo, dificultando sobremaneira a determinação da causa mortis pelo médico-legista.

\subsubsection{Locais de suicídio}

O conceito mais divulgado de suicídio é o proposto por Durkheim ${ }^{323}$, segundo o qual "chama-se suicídio todo caso de morte que resulta direta ou indiretamente de um ato, positivo ou negativo, realizado pela própria vítima, e que ela sabia que produziria esse resultado. A tentativa é o ato assim definido, mas interrompido antes que dele resulte a morte ${ }^{, 324}$.

Visto como um fenômeno social, as reações ao suicídio variam de cultura para cultura. É considerado pecado para a maioria das religiões, crime em alguns países e ato de honra em outros.

\footnotetext{
${ }^{322} \mathrm{~A}$ boa técnica recomenda que a reconstituição seja sempre ilustrada com croqui ou desenho esquemático.

${ }^{323}$ DURKHEIM, Émile. $O$ suicídio: estudo de sociologia. São Paulo: Martins Fontes, 2000. p. 14.

${ }^{324}$ Para Sigmund Freud, em uma abordagem psicanalítica, o pensamento suicida corresponde a um impulso assassino voltado contra si mesmo. Para ele, a auto-aversão observada na depressão tem origem no ódio direcionado ao objeto desejado. Incapaz de atingir seus objetivos, o ego é dominado pelo objeto e desvia a ira contra si próprio: "Tão imenso é o amor de si mesmo do ego (self-love), que chegamos a reconhecer como sendo o estado primevo do qual provém a vida instintual, e tão vasta é a quantidade de libido narcisista que vemos liberada no medo surgido de uma ameaça à vida, que não podemos conceber como esse ego consente em sua própria destruição. De há muito, é verdade, sabemos que nenhum neurótico abriga pensamentos de suicídio que não consistam em impulsos assassinos contra outros, que ele volta contra si mesmo, mas jamais fomos capazes de explicar que forças interagem para levar a cabo esse propósito. A análise da melancolia mostra agora que o ego só pode se matar se, devido ao retorno da catexia objetal, puder tratar a si mesmo como um objeto - se for capaz de dirigir contra si mesmo a hostilidade relacionada a um objeto, e que representa a reação original do ego para com objetos do mundo externo. Assim, na regressão desde a escolha objetal narcisista, é verdade que nos livramos do objeto; ele, não obstante, se revelou mais poderoso do que o próprio ego. Nas duas situações opostas, de paixão intensa e de suicídio, o ego é dominado pelo objeto, embora de maneiras totalmente diferentes" (FREUD, Sigmund. Luto e melancolia. Edição eletrônica brasileira das obras completas de Sigmund Freud. Rio de Janeiro: Imago).
} 
Embora para a legislação penal brasileira atual o suicídio constitua um fato atípico, sua ocorrência reclama a realização de perícia por três razões fundamentais. Primeiro, para que se possa efetivamente descartar a ocorrência de crime. Como vimos anteriormente, existe sempre a possibilidade de simulação, praticada pela própria vítima ou por familiares, na tentativa de encobrir a autoquíria, ou levada a efeito por terceiros, para ocultar a morte criminosa ${ }^{325}$.

Em segundo lugar, é preciso verificar se não houve participação de terceiros no suicídio, o que pode ocorrer nas modalidades auxílio, instigação ou induzimento, estas sim condutas típicas perante o Direito Penal pátrio (art. 122 do CP) ${ }^{326,327 .}$

Finalmente, ainda que o fato seja penalmente atípico, pode haver repercussão na esfera civil e a perícia será prova absolutamente necessária às questões que se seguirão.

Apesar de não ser o objetivo do presente trabalho analisar as causas do suicídio, mas sim os vestígios por ele produzidos, é necessário que o perito tenha um conhecimento mínimo sobre o comportamento suicida para melhor poder se orientar no local.

\section{Formas de suicídio}

Não existe uma forma padrão para o cometimento do ato extremo. Entretanto, embora os métodos utilizados possam ser variados, os suicidas costumam optar pelos de mais fácil execução e obtenção e, entre estes, os que causam menor sofrimento.

Nos Estados Unidos, por exemplo, foram registrados, no ano 2000, 31.655 casos de suicídio, distribuídos segundo a proporção abaixo ${ }^{328}$ :

\begin{tabular}{|l|c|c|}
\hline \multicolumn{1}{|c|}{ Método utilizado } & Número de casos & Percentual \\
\hline Armas de fogo & 17.108 & $54 \%$ \\
\hline Enforcamento & 6.462 & $20,4 \%$ \\
\hline Envenenamento & 5.486 & $17,3 \%$ \\
\hline Precipitação & 740 & $2,3 \%$ \\
\hline Armas brancas & 566 & $1,8 \%$ \\
\hline
\end{tabular}

\footnotetext{
${ }^{325}$ Ver item 2.6.6: "Vestígios e indícios mistos - sinais de luta".

${ }^{326}$ A comprovação do crime de participação em suicídio é bastante difícil, particularmente nas modalidades induzimento e instigação. Na modalidade auxílio é preciso demonstrar que o autor emprestou ajuda material para o ato extremo, fornecendo, por exemplo, os meios para que a vítima tirasse a própria vida.

${ }^{327}$ Trata-se de crime de resultado necessário que somente se aperfeiçoa se o suicídio é ao menos tentado e a vítima experimenta lesões de natureza grave.

${ }^{328}$ USA Suicide: 2000 - Official final data. American Association of Suicidology. Disponível em <www.suicidology.org>. Acesso em: 20 jan. 2006.
} 


\begin{tabular}{|l|c|c|}
\hline Afogamento & 368 & $1,2 \%$ \\
\hline Queimadura & 150 & $0,5 \%$ \\
\hline Outros & 775 & $2,5 \%$ \\
\hline Total & 31.655 & $100 \%$ \\
\hline
\end{tabular}

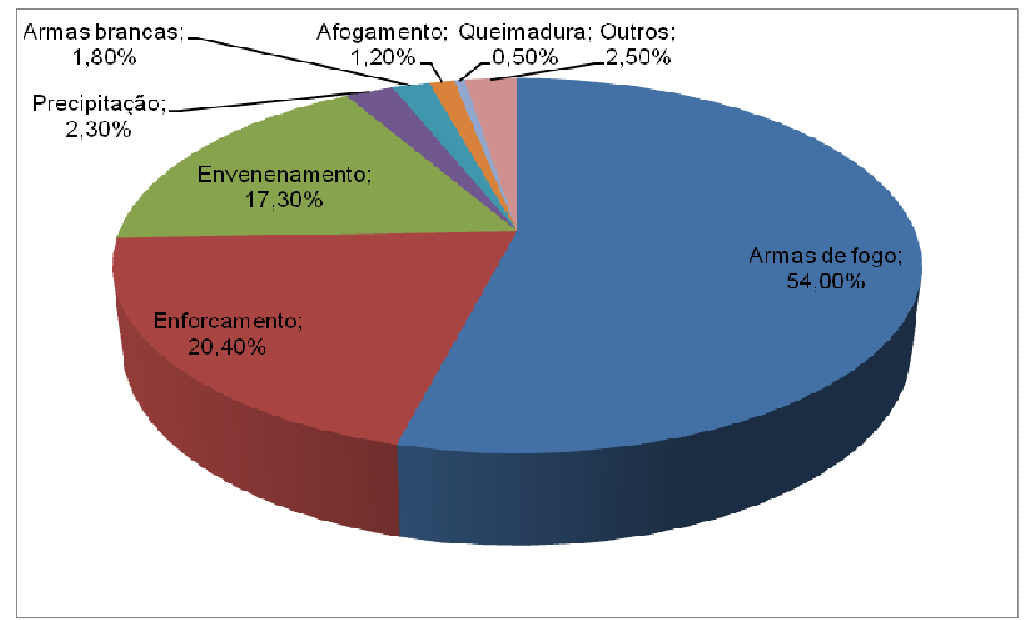

No Brasil, entre os anos de 1996 e 2005 foram registrados $72.600^{329}$ casos de suicídios, distribuídos segundo a proporção a seguir ${ }^{330}$ :

\begin{tabular}{|l|c|c|}
\hline \multicolumn{1}{|c|}{ Método utilizado } & Número de casos & Percentual \\
\hline Arma de fogo & 13.541 & $18,65 \%$ \\
\hline Envenenamento & 10.071 & $13,87 \%$ \\
\hline Enforcamento & 37.411 & $51,53 \%$ \\
\hline Precipitação & 1.871 & $2,58 \%$ \\
\hline Arma branca & 1.164 & $1,60 \%$ \\
\hline Afogamento & 906 & $1,25 \%$ \\
\hline Queimadura & 1.506 & $2,07 \%$ \\
\hline Outros & 6.130 & $8,45 \%$ \\
\hline Total & 72.600 & $100 \%$ \\
\hline
\end{tabular}

${ }^{329}$ Embora as estatísticas oficiais considerem um número ligeiramente superior, considerei apenas os casos catalogados como lesões autoprovocadas intencionalmente, assim catalogadas no CID-10 (X60 a X84).

${ }^{330}$ Fonte: DATASUS. Disponível em: <www.datasus.gov.br>. 


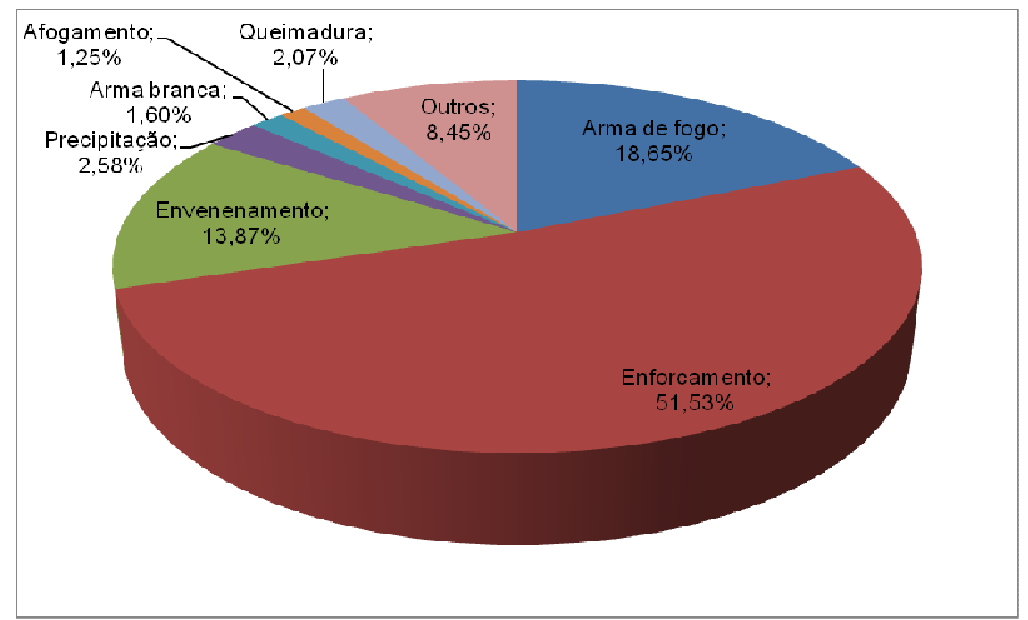

A discrepância na escolha dos meios, que privilegia as armas de fogo nos Estados Unidos e o enforcamento no Brasil, decorre da influência das características regionais e da facilidade em se obter um ou outro recurso que permita pôr termo à própria vida.

Guardadas as devidas proporções, verifica-se que quatro são as modalidades mais comuns de suicídio (respondem por mais de $85 \%$ dos casos): enforcamento, envenenamento, arma de fogo ${ }^{331}$ e precipitação. Todas as demais opções ocupam nível residual.

\section{Número de suicídios ${ }^{332}$}

O Brasil possui uma das menores taxas de suicídio do mundo, inferior a 4,7 por 100.000 habitantes, enquanto a média mundial é de $14^{333}$. Os maiores índices são do Rio Grande do Sul (10 para cada 100 mil), sendo Porto Alegre a capital com maior taxa de suicídios (11,9 para cada 100 mil). A cidade brasileira com o maior índice é o Município de Venâncio Aires, com mais de 40 casos a cada 100 mil habitantes. Uma das causas apontadas é o agrotóxico Tamarón ${ }^{334}$, utilizado em larga escala no cultivo do fumo ${ }^{335}$.

\footnotetext{
${ }^{331}$ Por meio de diversos tipos de drogas e meios de administração.

${ }^{332}$ Ver o número absoluto de suicídios em: Suicídios consumados e tentados.

${ }^{333}$ No Japão, onde o ato extremo está incorporado no comportamento social, as estatísticas apontam que a taxa de suicídios chegou a 34, por cem mil habitantes, em 2000, caindo para 27 em 2003.

${ }^{334} \mathrm{O}$ Tamarón ou metamidophos, é um organofosforado de ação sistêmica que age por contato ou ingestão.

${ }^{335}$ FALK, João Werner; CARVALHO, Lenine Alves de; SILVA, Letícia Rodrigues da; PINHEIRO, Sebastião. Suicídio e doença mental em Venâncio Aires/RS: Conseqüência do uso de agrotóxicos organofosforados: Relatório preliminar de pesquisa. Disponível em: $<$ http://galileu.globo.com/edic/133/agro2.doc>. Acesso em: 10 de janeiro de 2007.
} 
O quadro a seguir reproduz as taxas de suícidio nas diversas unidades da Federação entre 2000 e $2005^{336}$ :

\begin{tabular}{|lcccccc|}
\hline \multicolumn{7}{c|}{ Taxas de suicídios no Brasil } \\
\hline $\mathbf{2 0 0 0}$ & $\mathbf{2 0 0 1}$ & $\mathbf{2 0 0 2}$ & $\mathbf{2 0 0 3}$ & $\mathbf{2 0 0 4}$ & $\mathbf{2 0 0 5}$ \\
\hline Acre & 4,84 & 5,06 & 3,75 & 4,33 & 4,04 & 2,88 \\
Alagoas & 2,55 & 3,36 & 2,91 & 2,33 & 3,15 & 2,59 \\
Amapá & 3,35 & 6,02 & 7,16 & 6,92 & 6,63 & 6,9 \\
Amazonas & 2,74 & 3,25 & 2,73 & 3,04 & 3,1 & 2,81 \\
Bahia & 1,55 & 1,82 & 1,81 & 2,22 & 1,89 & 2,61 \\
Ceará & 3,62 & 4,98 & 6,02 & 5,4 & 5,75 & 6,63 \\
Distrito Federal & 4,19 & 3,77 & 4,19 & 3,93 & 4,34 & 3,81 \\
Espírito Santo & 3,42 & 3,68 & 4 & 4,62 & 4,5 & 4,87 \\
Goiás & 6,54 & 6,47 & 7,31 & 6,18 & 6,06 & 5,98 \\
Maranhão & 1,26 & 1,9 & 2,15 & 1,53 & 1,64 & 1,9 \\
Mato Grosso & 5,67 & 5,63 & 5,87 & 6,11 & 5,78 & 5,42 \\
Mato Grosso do Sul & 8,33 & 6,54 & 7,85 & 8,62 & 8,61 & 8,57 \\
Minas Gerais & 3,36 & 4,41 & 4,38 & 5,11 & 4,77 & 5,17 \\
Pará & 1,87 & 2,31 & 2,17 & 2,08 & 1,99 & 2,38 \\
Paraíba & 1,07 & 1,3 & 2,12 & 2,27 & 2,61 & 2,95 \\
Paraná & 6,13 & 6,85 & 5,91 & 5,99 & 6,69 & 6,52 \\
Pernambuco & 3,47 & 3,36 & 3,18 & 3,64 & 3,52 & 3,67 \\
Piauí & 2,6 & 3,97 & 4,11 & 4,75 & 5,34 & 4,92 \\
Rio de Janeiro & 2,72 & 3,14 & 3,14 & 2,4 & 2,61 & 2,78 \\
Rio Grande do Norte & 3,06 & 4,12 & 3,68 & 5,12 & 3,88 & 5,36 \\
Rio Grande do Sul & 10,03 & 10,04 & 9,91 & 9,85 & 9,8 & 9,94 \\
Rondônia & 5,51 & 5,4 & 3,07 & 3,64 & 4,18 & 4,17 \\
Roraima & 6,78 & 5,05 & 5,48 & 5,6 & 7,12 & 6,9 \\
Santa Catarina & 7,95 & 8,5 & 7,91 & 7,22 & 7,31 & 7,65 \\
São Paulo & 3,82 & 4,35 & 4,07 & 4,01 & 3,84 & 4,02 \\
Sergipe & 2,69 & 3,8 & 4,33 & 4,32 & 4,14 & 4,12 \\
Tocantins & 3,28 & 3,97 & 4,14 & 5,85 & 4,61 & 5,21 \\
\hline Total & $\mathbf{3 , 9 9}$ & $\mathbf{4 , 4 9}$ & $\mathbf{4 , 4 2}$ & $\mathbf{4 , 4 4}$ & $\mathbf{4 , 4 1}$ & $\mathbf{4 , 6 4}$ \\
\hline
\end{tabular}

${ }^{336}$ Fonte: DATASUS. Disponível em: <www.datasus.gov.br>. 


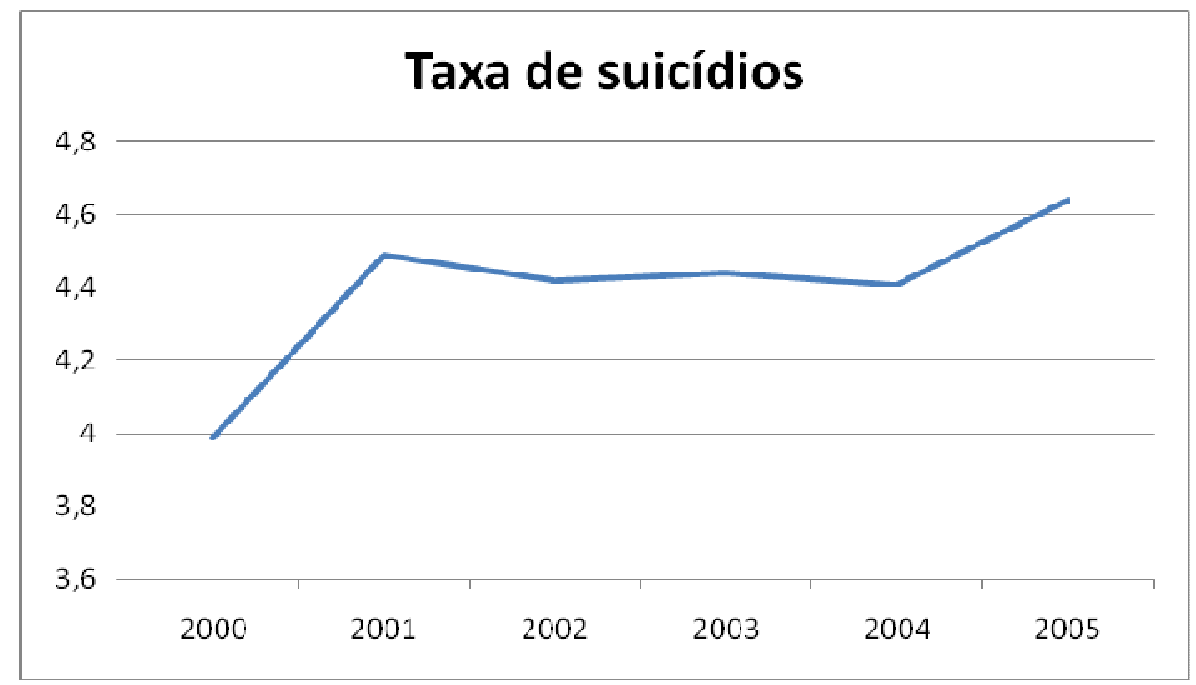

\section{Causas do suicídio}

Fenômeno bastante complexo, as causas do suicídio podem ser subdivididas $\mathrm{em}^{337}$ :

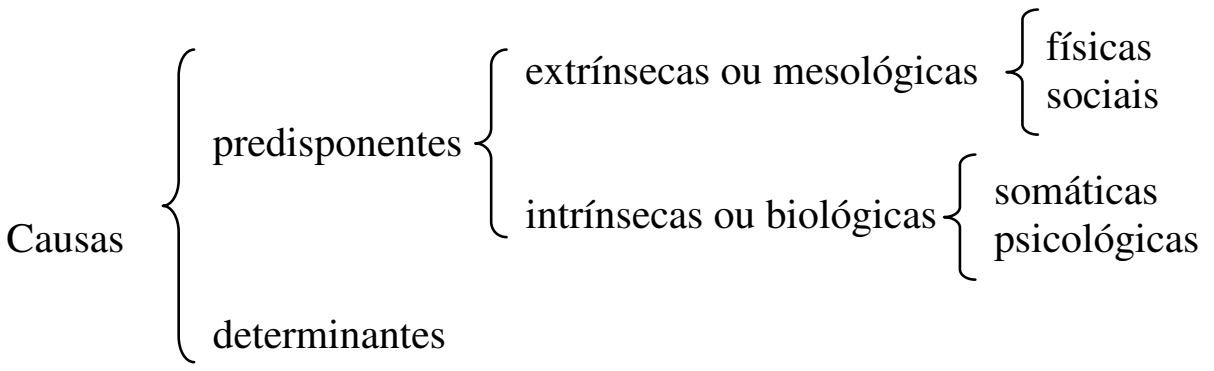

\section{Causas predisponentes extrínsecas físicas do suicídio}

Como causas predisponentes físicas do suicídio podemos citar os fatores sazonais. Muito embora as estatísticas sejam bastante variadas, há maior predisponência nos dias muito quentes, no início e no final do ano, no fim e no começo do mês, da semana ou do $\operatorname{dia}^{338}$.

\footnotetext{
${ }^{337}$ Simonin (op. cit., p. 926.) fala em predisponentes, determinantes e ocasionais. Flamínio Fávero (FÁVERO, Flamínio. Medicina legal. 11 ed. São Paulo: Martins, 1980. p. 250) prefere falar em fatores e motivos determinantes, subdividindo os primeiros em mesológicos (físicos ou sociais) e biológicos.

${ }^{338}$ Apud FÁVERO, Flamínio. op. cit., p. 251.
} 


\section{Causas predisponentes extrínsecas sociais do suicídio}

Entre as causas predisponentes sociais podem ser apontadas a urbanização ${ }^{339}$, o aumento da criminalidade ${ }^{340}$, a desintegração da família $^{341}$, a miséria extrema ${ }^{342}$, fatores políticos ou religiosos ${ }^{343}$, a sugestão, imitação ou contágio ${ }^{344}$ e outros.

\section{Causas predisponentes intrínsecas somáticas do suicídio}

São inúmeras as causas predisponentes, biológicas, somáticas (físicas) que podem conduzir ao auto-sacrifício:

a) sexo - o suicídio é mais freqüente no homem que na mulher ${ }^{345}$. Na Europa, a razão de suicídios entre os sexos mostra existirem maiores diferenças na Finlândia, Grécia, Irlanda e Portugal, registrando-se uma proporção de até quatro suicídios no sexo masculino para um no feminino ${ }^{346}$;

b) faixa etária - já ficou demonstrado que o suicídio é mais freqüente entre os 15 e os 25 anos e entre os 45 e 55 anos de idade ${ }^{347}$. No primeiro caso, a maior incidência pode ser atribuída aos distúrbios da adolescência e ao abuso de drogas. No segundo, ao início do declínio e ao desemprego;

\footnotetext{
${ }^{339}$ A dura realidade dos grandes centros urbanos leva à frustração de expectativas e à depressão.

${ }^{340}$ A criminalidade pode aumentar a taxa de suicídios por diversos mecanismos. Primeiro, a tensão social causada pela escalada de violência pode agravar os quadros psicológicos preexistentes. Em segundo lugar, o suicídio pode ser praticado pelo criminoso como última saída para furtar-se à aplicação da Justiça. Por derradeiro, os criminosos podem pôr termo à própria vida pelo temor de serem apanhados por grupos rivais.

${ }^{341} \mathrm{O}$ número de suicídios aumenta entre os solteiros e os divorciados, mostrando que a presença da família é inegável fator de estabilidade emocional.

${ }^{342}$ Artigo de Robert Sapolsky, publicado na revista Scientific American Brasil, demonstra claramente a influência negativa e marcante da pobreza sobre a saúde (SAPOLSKY, Robert. Doentes de pobreza. Scientific American Brasil, no 45, p. 74-81, fev. 2006).

${ }^{343}$ Os pilotos camicases japoneses que atacaram Pearl Harbor, em 7 de dezembro de 1941, e a escalada dos ataques terroristas depois de 11 de setembro de 2001 são exemplos da influência político-religiosa nos atos suicidas.

${ }^{344}$ Um exemplo gritante da sugestão, imitação ou contágio ocorreu no Japão, com a edição da obra Kanzen jisatsu manyuaru (Manual completo do suicídio), de autoria de Wataru Tsurumi, em 1993. O livro tornouse um best seller e a taxa de suicídios aumentou sensivelmente. Mais recentemente o Japão enfrentou outra onda de pactos suicidas coletivos travados pela Internet (foram 91 pessoas em 2005), forma de contágio em uma civilização que parece cultuar a autoquíria.

${ }^{345}$ Embora as tentativas sejam mais freqüentes nas mulheres. Ver: "Suicídio consumado e tentativa".

${ }^{346}$ Dados mundiais revelam que em 2002 o número de suicídios foi maior no sexo masculino em todas as classes etárias, sendo o aumento progressivo com a idade.

${ }^{347} \mathrm{Em} 2002$, foram registrados na União Européia total de 164.150 óbitos por suicídio e lesões autoinfligidas, em ambos os sexos, dos quais 88.412 na faixa etária dos 30 aos 59 anos.
} 
c) raça - no nosso meio são mais freqüentes os suicídios de estrangeiros, negros e mulatos. Para Flamínio Fávero ${ }^{348}$, os números não podem ser atribuídos propriamente às diferenças raciais, mas à inadaptação social e eventualmente à situação socioeconômica;

f) instrução e profissão - segundo a maioria dos autores, o ato extremo é mais freqüente entre pessoas instruídas e que têm profissão liberal, sendo menos comum nos pouco instruídos e operários;

g) herança genética - parece inegável a possibilidade de existir uma predisposição genética para o suicídio, já que em algumas famílias o ato extremo vem sendo praticado por gerações. Alguns autores, entretanto, negam essa influência, porquanto é difícil distinguir se há realmente uma tendência hereditária para a autodestruição ou se é o ambiente familiar deteriorado que colabora para o aparecimento de distúrbios psicológicos, que se perpetuam e acabam por levar ao suicídio. Nesse sentido, a observação de $\operatorname{Simonin}^{349}$ : “a monomania ${ }^{350}$ do suicídio não existe. O que é hereditário em todos os casos não é o suicídio, mas a psicose que o engendra”.

\section{Causas predisponentes intrínsecas psicológicas do suicídio}

Essa categoria de causas corresponde a alguns estados mentais, crônicos ou episódicos, como a demência, a esquizofrenia, transtornos psicóticos, do humor, de ansiedade, relacionados a substâncias (alcoolismo, por exemplo) e outros que podem constituir fatores suicidógenos de risco.

É importante entender que nem sempre esses fatores estão presentes e, a contrário senso, se presentes, nem sempre levarão ao suicídio.

A decisão de pôr termo à própria vida é extremamente complexa e implica na análise de uma série de fatores e circunstâncias que tornam único cada caso analisado, permitindo, no máximo, o vislumbre de algumas linhas gerais de comportamento.

\footnotetext{
${ }^{348}$ FÁVERO, Flamínio. op. cit., p. 253.

${ }^{349}$ SIMONIN, Camille. op. cit., p. 928.

${ }^{350}$ Monomania é o desequilíbrio psicológico em que um único pensamento ocupa a mente do indivíduo.
} 


\section{Causas determinantes}

São causas que rompem o frágil equilíbrio psicológico provocando um choque emocional que acaba por desencadear o comportamento suicida.

Empiricamente a normalidade da vida humana repousa em três fatores principais, a saúde, a estabilidade emocional e a estabilidade financeira. $\mathrm{O}$ abalo a qualquer deles faz com que surja um desequilíbrio perturbador que, dependendo do grau de interferência na qualidade de vida, e da presença das demais causas consideradas, pode levar ao suicídio.

Importante notar que essa perturbação não precisa ser necessariamente negativa, como a ocorrência de uma enfermidade ou a perda de um ente querido. Algumas interferências positivas, como a paixão por uma causa ou o fanatismo religioso, também podem determinar o desequilíbrio emocional e levar ao ato extremo.

O gráfico resume os principais fatores determinantes do suicídio:

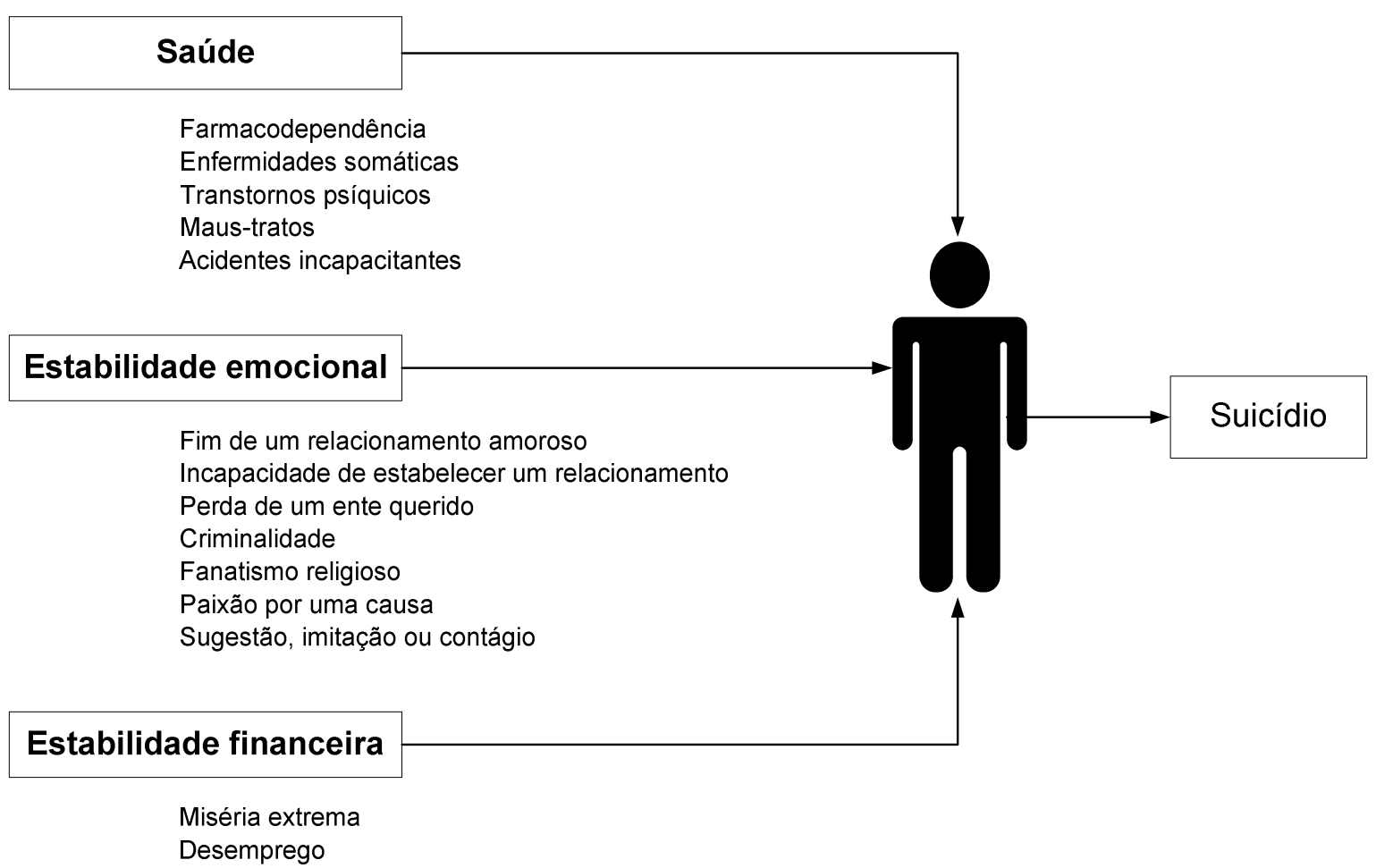

Ainda com relação à etiologia, Durkheim ${ }^{351}$ idealizou seis espécies de suicídios, três elementares e três mistas.

\footnotetext{
${ }^{351}$ DURKHEIM, Émile. op. cit., p. 377.
} 
Elementares $\left\{\begin{array}{l}\text { Egoísta - Apatia }\left\{\begin{array}{l}\text { Melancolia indolente com complacência por si mesmo } \\ \text { Sangue frio desencantado do céptico }\end{array}\right. \\ \text { Altruísta - Energia passional ou voluntariosa }\left\{\begin{array}{l}\text { Com sentimento tranqüilo de dever } \\ \text { Com entusiasmo místico } \\ \text { Com coragem tranqüila }\end{array}\right. \\ \text { Anômico - Irritação ou desgosto }\left\{\begin{array}{l}\text { Recriminações violentas contra a vida em geral } \\ \text { Recriminações violentas contra uma pessoa em particular } \\ \text { (homicídio/suicídio })\end{array}\right.\end{array}\right.$ Mistas $\left\{\begin{array}{l}\text { Ego-anômico - Mistura de agitação e apatia, de ação e devaneio } \\ \text { Anômico-altruísta - Efervescência exasperada } \\ \text { Ego-altruísta - Melancolia moderada por uma certa firmeza moral }\end{array}\right.$

\section{Suícídio consumado e tentativa}

Embora possa parecer que as tentativas são sempre suicídios malsucedidos, a prática tem demonstrado que os suicídios tentados compõem uma categoria de fenômeno distinta da forma consumada, na qual a vítima tenta comunicar o seu sofrimento para ser socorrida. Não há, em princípio, o desejo real de pôr termo à própria vida, mas sim de obter atenção e auxílio.

Tanto isso é verdade que as estatísticas relativas aos casos consumados e tentados são significativamente diversas. Estudos realizados pela Secretaria de Saúde e Defesa Civil do Estado do Rio de Janeiro sobre as 2.231 tentativas de suicídio ocorridas no Estado entre 2002 e $2006^{352}$ demonstraram dados bastante interessantes.

Há, segundo a pesquisa, uma média de vinte tentativas para cada suicídio consumado. Enquanto os homens lideram as taxas de suicídios consumados (79\%), as mulheres os suplantam, em duas a três vezes, na modalidade tentada $(65 \%)$.

\begin{tabular}{|l|c|c|c|c|c|c|c|c|c|c|c|c|}
\hline \multicolumn{10}{|c|}{ Suicídios consumados no Brasil } \\
\hline & $\mathbf{1 9 9 6}$ & $\mathbf{1 9 9 7}$ & $\mathbf{1 9 9 8}$ & $\mathbf{1 9 9 9}$ & $\mathbf{2 0 0 0}$ & $\mathbf{2 0 0 1}$ & $\mathbf{2 0 0 2}$ & $\mathbf{2 0 0 3}$ & $\mathbf{2 0 0 4}$ & $\mathbf{2 0 0 5}$ & Total & $\boldsymbol{\%}$ \\
\hline Ignorado & 4 & 0 & 6 & 0 & 0 & 2 & 3 & 2 & 0 & 3 & 20 & 0,03 \\
Feminino & 1.391 & 1.408 & 1.440 & 1.224 & 1.353 & 1.529 & 1.656 & 1.553 & 1.650 & 1791 & 14.995 & 20,65 \\
Masculino & 5.278 & 5.465 & 5.468 & 5.293 & 5.300 & 6.044 & 5.900 & 6.090 & 6.108 & 6639 & 57.585 & 79,32 \\
Total & 6.673 & 6.873 & 6.914 & 6.517 & 6.653 & 7.575 & 7.559 & 7.645 & 7.758 & 8.433 & 72.600 & 100 \\
\hline
\end{tabular}

\footnotetext{
${ }^{352}$ SESDEC-RJ. Atenção às tentativas de suicídio na rede de hospitais estaduais do Rio de Janeiro. Secretaria de Saúde de Estado e Defesa Civil do Rio de Janeiro. Disponível em: $<\mathrm{http} / / / \mathrm{www}$.webdimensions.com.br/conass/atencao_as_tentativas_de_suicidio_rede_hospitais_estaduais.p df>. Acesso em: 22 out. 2008.

${ }^{353}$ Fonte: DATASUS. Disponível em: <www.datasus.gov.br>.
} 


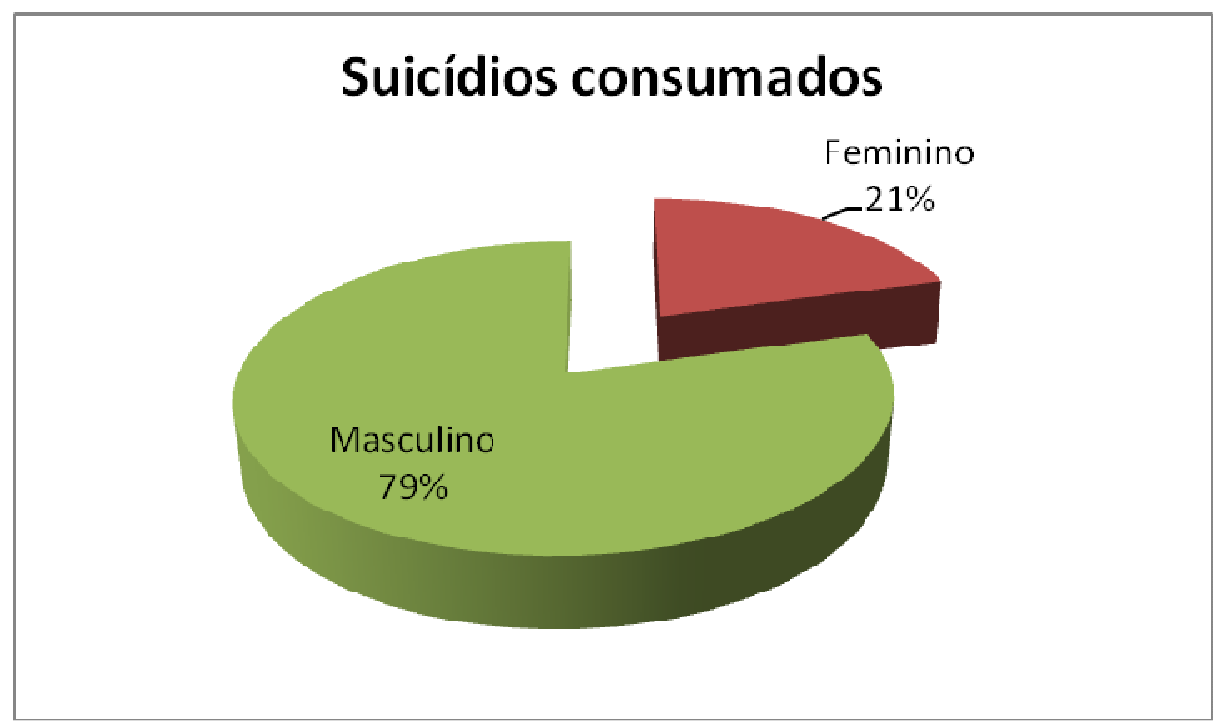

\begin{tabular}{|lc|}
\hline \multicolumn{2}{|c|}{ Suicídios tentados no Brasil } \\
\hline Feminino & $65 \%$ \\
\hline Masculino & $35 \%$ \\
\hline
\end{tabular}

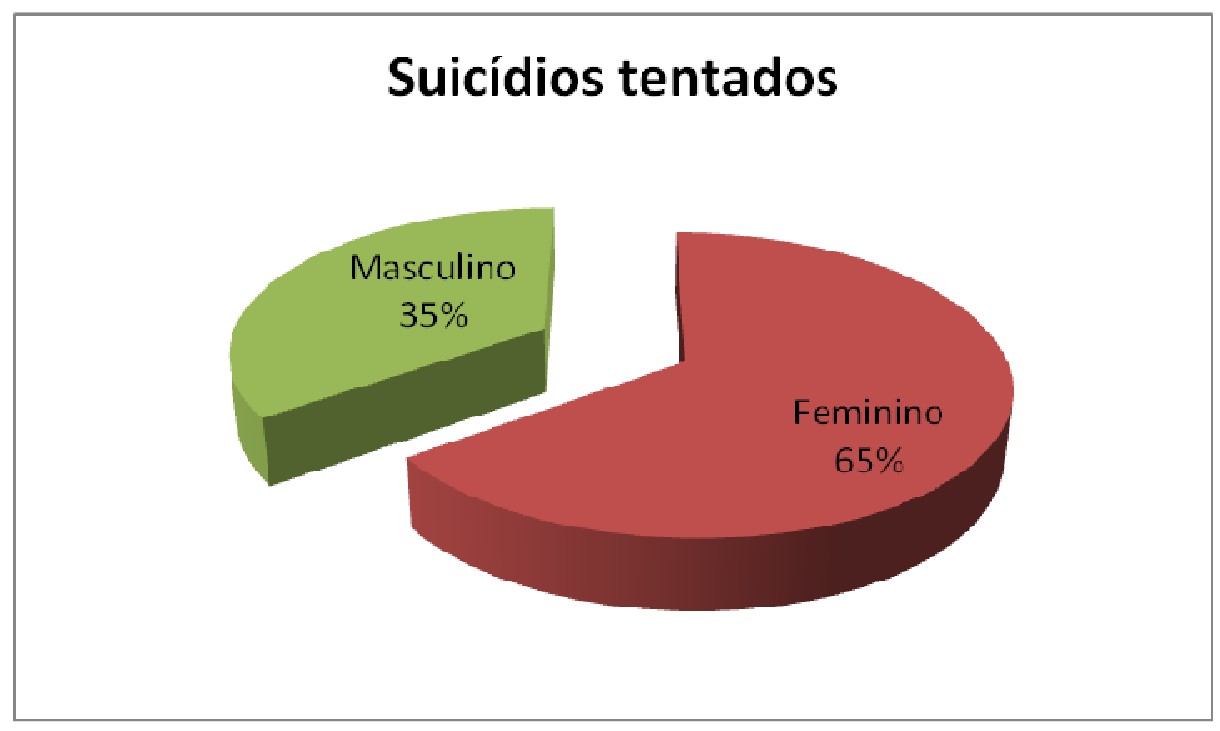

Também no que toca às modalidades, vamos encontrar grandes discrepâncias. Enquanto nos suicídios consumados a prevalência do meio empregado recai sobre métodos efetivos de suprimir a própria vida, como precipitação, enforcamento ou armas de fogo, nas tentativas a opção privilegia métodos que permitirão tempo hábil à intervenção de terceiros, como a ingestão de medicamentos ou o seccionamento dos pulsos. 


\subsubsection{O exame do local de suicídio}

Poucos locais pedem tanta atenção como os suspeitos da ocorrência de suicídio consumado $^{354}$. O exame do local implica na análise das causas do ato extremo, o exame do local propriamente dito, do corpo e dos meios empregados.

\section{Análise das causas do suicídio}

Deparando-se com um quadro que possa indicar suicídio, o perito deve, inicialmente, proceder a uma rápida autópsia psicológica ${ }^{355}$, em busca de antecedentes que possam justificar a perda voluntária da vida. O suicida, por intermédio de suas ações, procura dizer algo à sociedade. Cabe ao técnico interpretar a linguagem silenciosa da morte e trazer justificativa ao ato praticado ${ }^{356}$.

Essa apreciação preliminar é importante porque permitirá uma avaliação, ainda que perfunctória, do estado mental da vítima, o que poderá orientar o exame e explicar alguns achados incomuns de local.

\section{O exame do local}

A perícia deve ser orientada para a comprovação, ou não, da morte voluntária, e os cuidados que devem ser dispensados ao local variam de acordo com o meio utilizado.

Há providências gerais, como analisar e anotar a disposição dos móveis e objetos, a existência ou não de vestígios de $\operatorname{luta}^{357}$, os meios de acesso, a posição relativa do corpo

\footnotetext{
${ }^{354}$ Nos suicídios tentados, se não houve comprometimento das faculdades mentais, a vítima poderá esclarecer as razões de ter atentado contra a própria vida.

${ }^{355}$ Trata-se de uma espécie de inquérito retrospectivo que pode abranger desde a análise dos bilhetes eventualmente deixados até entrevista com familiares e a reconstrução mental dos últimos dias da vítima para estabelecer se havia motivos para o ato extremado.

${ }^{356 ، " H a ́ ~ u m a ~ m o r t e ~ q u e ~ v e m ~ d e ~ f o r a ~ e ~ u m a ~ m o r t e ~ q u e ~ c r e s c e ~ p o r ~ d e n t r o . ~ C a d a ~ u m a ~ d e l a s ~ p r o d u z ~ u m a ~ d o r ~}$ diferente. A morte do suicida é diferente. Pois ela não é coisa que venha de fora, mas gesto que nasce de dentro. O seu cadáver é seu último acorde, término de uma melodia que vinha sendo preparada no silêncio do seu ser. A primeira morte não foi um gesto; foi um acontecimento de dor. Por isso ela é para ser chorada; não é um texto para ser lido. Mas no corpo do suicida encontra-se uma melodia para ser ouvida. Ele deseja ser ouvido. Para ele valem as palavras de César Vallejo: 'su cadáver estava lleno de mundo'. O seu silêncio é um pedido para que ouçamos uma história cujo acorde necessário e final é aquele mesmo, um corpo sem vida" (ALVES, Rubem. O morto que canta. In: CASSORLA, Roosevelt Moisés Smeke (Org.). Suicídio: estudos brasileiros. Campinas, SP: Papirus, 1991. p. 12).

${ }^{357}$ Ver item 2.6.6: "Vestígios e indícios mistos - sinais de luta".
} 
ou a presença de documentos escritos ou outros indícios que possam indicar a intenção da vítima.

Há, também, diligências específicas, relacionadas com o meio empregado.

Nos suicídios cometidos com emprego de arma de fogo, necessariamente e independente de requisição da autoridade, é necessário colher material das mãos da vítima para exame residuográfico. Também é possível encontrar disparos para teste da arma, feitos contra paredes ou objetos próximos.

Na hipótese de ter sido utilizada uma arma branca, a morte pode ser lenta, fazendo com que a vítima, em sua agonia, produza manchas de sangue que não necessariamente indicarão agressão.

Os casos de envenenamento pedem que o perito procure encontrar restos da substância empregada ou, ao menos, algo que a indique. Não se deve esquecer que esses achados precisam ser comunicados ao médico-legista para que a necropsia possa ser orientada.

Nos enforcamentos é importante determinar se a vítima tinha condições de prender o baraço $^{358}$ no ponto de apoio e colocar o pescoço no laço da forma como foi encontrada. Se o ato ocorreu em uma prisão, no interior de cela coletiva, a atenção precisa ser redobrada.

As precipitações exigem um exame acurado do local de onde ocorreu a queda, do trajeto percorrido pelo corpo até atingir o solo e o sítio do embate contra o piso ${ }^{359}$.

Suicídios atípicos, da mesma forma, só podem ser afirmados se o perito conseguir demonstrar claramente a ausência de violência praticada por terceiros e que o óbito decorreu dos meios empregados pela própria vítima, de forma voluntária e consciente.

\section{O exame do corpo}

Deve abranger, particularmente, o estudo da posição e da possibilidade de a vítima ter praticado o ato da forma como o local parece demonstrar.

Há situações, como bem lembra Flamínio Fávero $^{360}$, em que a posição do corpo é tão esdrúxula que de plano exclui a hipótese de suicídio, como o encontro de um cadáver

\footnotetext{
${ }^{358}$ Corda ou cordel.

${ }^{359}$ Ver item 2.7.3.5: "Locais de morte por precipitação".

${ }^{360}$ FÁVERO, Flamínio. op. cit., p. 264.
} 
em suspensão completa, sem qualquer móvel ou outro auxílio que permitisse a conclusão de enforcamento voluntário ${ }^{361}$.

Como regra, na maior parte dos suicídios, a vítima procura uma situação de conforto para a prática do ato. Antes de desferir o disparo fatal, por exemplo, irá deitar-se ou sentar em um local de onde o corpo não cairá no chão após a morte. Isso não significa, porém, que não possa ocorrer de modo diverso. Há inúmeros suicídios atípicos, em que a vítima escolhe meios dolorosos ou coloca-se em situação de desconforto para a prática do ato e nem por isso o fato deixará de ser suicídio. Cada caso é um caso, com suas peculiaridades e circunstâncias.

Também é comportamento comum deixar objetos pessoais como óculos, relógio ou jóias depositados sobre uma mesa próxima ou guardados cuidadosamente antes da morte.

As vestes, quando existentes ${ }^{362}$, devem estar alinhadas e mostrar danificações apenas em correspondência com eventuais ferimentos. Nos suicídios cometidos com emprego de arma de fogo, em disparo realizado contra a região torácica, não raro a vítima afasta a blusa ou camisa para encostar a arma diretamente sobre a pele do peito.

As zonas de esfumaçamento e chamuscamento tanto podem comprometer as vestes como apresentar-se apenas sobre elas ${ }^{363}$. Em qualquer caso precisam ser recolhidas e preservadas para ulteriores exames ${ }^{364}$.

O estudo das lesões é fundamental e abrange a natureza, a sede, o número, a orientação e a extensão.

Quanto à natureza, os ferimentos e marcas devem corresponder ao meio utilizado.

No que toca à localização, nos suicídios por arma de fogo a vítima geralmente procura atingir uma região que produza uma morte rápida e indolor, daí serem a cabeça ${ }^{365}$ e o precórdio as zonas de eleição. Para as armas brancas, as regiões de preferência são o precórdio e os vasos do pescoço ou dos punhos.

\footnotetext{
${ }^{361}$ Antes de concluir pelo crime, o perito precisa descartar eventual inovação dolosa ou culposa do local.

${ }^{362}$ Em significativa parcela de suicídios, a vítima apresenta-se despida.

${ }^{363}$ Casacos, jaquetas e roupas muito grossas podem absorver totalmente as zonas de esfumaçamento e chamuscamento. Nessas condições, um médico-legista desavisado, e que não tenha tido contato com as vestes, poderá diagnosticar um disparo à distância quando na verdade o tiro foi encostado.

${ }^{364}$ Ver item 2.6.4.33: "Peças de vestuário e acessórios".

${ }^{365} \mathrm{Na}$ cabeça, as regiões mais atingidas são as temporais, parietais, auriculares (tiro no ouvido) ou o interior da cavidade bucal.
} 
O número de lesões também varia com o meio utilizado.

Nos suicídios praticados com armas brancas, os ferimentos podem ser múltiplos. Além disso, é comum o encontro de lesões de hesitação. São cortes superficiais produzidos pelo suicida antes de aprofundar a lâmina.

Nos casos em que houve emprego de arma de fogo, como padrão, a lesão é única. Entretanto, como veremos, trata-se de regra que admite algumas exceções.

A orientação dos ferimentos é de extrema importância e o perito precisa demonstrar que efetivamente poderiam ter sido produzidas pela própria vítima.

Finalmente, a extensão pode indicar se a lesão analisada foi ou não a causa da morte da vítima, o que assume particular importância na hipótese de ferimentos múltiplos.

\section{O exame dos meios empregados}

A determinação do instrumento ou meio utilizado para a prática do suicídio pode ser feita de forma direta ou indireta ${ }^{366}$.

Será direta quando o perito puder encontrar o instrumento utilizado para a prática do ato extremo no ou junto ao corpo da vítima, como a arma de fogo com a qual foi desferido o disparo fatal, o projétil recolhido das entranhas, a corda utilizada no enforcamento, a lâmina com que a vítima seccionou os pulsos, o encontro do tóxico fatal no exame das vísceras, etc. Para afirmar suicídio, porém, não basta encontrar o meio, é preciso que se reúnam as seguintes constatações:

a) o nexo de ligação entre o instrumento e as lesões observadas;

b) a comprovação de que a própria vítima voluntariamente deu causa a essas lesões;

c) a constatação de que os ferimentos foram produzidos em vida; e

d) a ausência de elementos que possam indicar a ocorrência de crime.

A determinação será indireta quando restar apenas a lesão, e o instrumento, por qualquer motivo, tiver sido retirado do local.

${ }^{366}$ Apud FÁVERO, Flamínio. op. cit., p. 265. 


\section{Suicídios mistos}

Embora incomum, é possível encontrar suicídios em que foram utilizados, pela vítima, mais de um meio para a consecução de seu objetivo final. São exemplos: a ingestão de substância tóxica seguida do uso de uma arma de fogo, o seccionamento dos vasos do pulso combinado com precipitação ou uso de uma arma de fogo e o afogamento. Embora raros, esses casos demonstram o firme propósito de pôr termo à própria vida ou forte desequilíbrio emocional ${ }^{367}$.

\subsubsection{Discussão sobre alguns suicídios atípicos}

Feita uma análise geral sobre os cuidados que devem ser tomados em um local onde possivelmente tenha ocorrido uma morte voluntária, passaremos a discutir alguns casos reais para que se possa ter uma idéia de como são variadas e complexas as ocorrências:

\subsubsection{Suicídios cometidos com mais de um disparo ou mais de uma arma de fogo}

Uma hipótese específica recomenda sempre cuidados adicionais: o suicídio cometido com mais de um disparo ou mais de uma arma de fogo.

Existe uma crença geral, incorreta, no sentido de que os ferimentos produzidos por projéteis, que comprometem regiões vitais, como o coração ou o crânio, levam necessariamente a uma morte instantânea, e que a presença de mais de um ferimento, decorrentes de disparos distintos, obrigatoriamente implicaria em crime.

Embora exista real possibilidade da ocorrência de crime e essa hipótese precise ser cuidadosamente descartada pelo perito, não é o número de armas utilizadas nem o de ferimentos que irá determinar a etiologia jurídica da ocorrência.

\footnotetext{
${ }^{367}$ Em uma ocorrência atendida pelo Instituto de Criminalística de São Paulo, a vítima, após ingerir certa quantidade de soda cáustica e seccionar os vasos do pulso, atirou-se pela janela.
} 
As mortes instantâneas são raras. É perfeitamente possível que uma pessoa, ferida mortalmente no coração ou no crânio, tenha ainda alguns segundos de consciência e força para realizar um segundo e um terceiro disparo contra o próprio corpo.

Além disso, é de se considerar a possibilidade de o primeiro disparo não ter atingido região vital, permitindo tempo suficiente para uma segunda tentativa. Da mesma forma, munições antigas, com baixa energia cinética, podem não penetrar no corpo o suficiente para determinar uma lesão fatal, dando oportunidade para disparos subseqüentes.

Sendo assim, diante de um quadro como o relatado, o perito precisa analisar todo o local, pesquisar os antecedentes da vítima e ouvir o médico-legista sobre a sequiência provável dos disparos e sobre a possibilidade de sobrevida depois do primeiro.

Somente após pesquisar o quadro completo e descartar totalmente a hipótese de crime é que poderá afirmar a ocorrência do ato extremo.

\subsubsection{Locais de morte por precipitação}

Poucos locais pedem tanta atenção como os de morte por precipitação, em razão da possibilidade de uma simulação.

A necessidade de estabelecer o diagnóstico jurídico da morte, ou seja, criminosa, acidental ou suicida, reclama exame minucioso do corpo, dos antecedentes e, principalmente, do local em que ocorreu a queda.

Como em outras ocorrências em que são observados ferimentos contusos de grandes proporções, como as de explosão ou acidentes ferroviários, ferimentos menores, também produzidos por agentes contundentes ou cortocontundentes, podem passar despercebidos em um exame menos acurado.

É possível, também, que a lesão inicial, produzida no local da queda, não tenha produzido a morte da vítima, mas apenas fez com que perdesse a consciência facilitando a defenestração.

Ao cair de grandes alturas, em decorrência do aumento da pressão interna, provocada pela compressão brusca contra o anteparo fixo (solo), o corpo se expande e literalmente explode, como uma bola cheia de água atirada no chão. Esse fenômeno é mais 
evidente nas pessoas obesas, em razão da densidade e do volume da gordura corpórea ou quando é a cabeça que atinge o solo com mais violência.

A perícia das ocorrências de precipitação abrange três providências:

a) o exame do local de onde ocorreu a queda;

b) exame da trajetória do corpo; e

c) exame do cadáver.

\section{Exame do local de onde ocorreu a queda}

O exame do local de onde o corpo caiu revela-se de maior importância. Nos suicídios, com freqüência, não há sinais de luta ${ }^{368}$. Se a queda ocorreu de uma janela, é preciso verificar se a vítima tinha condições de subir no parapeito e dali pular ao encontro da morte.

Pessoas muito velhas ou doentes podem necessitar do auxílio de um banquinho ou mesa, que invariavelmente estará encostado próximo à janela. A pesquisa dos motivos e eventual bilhete de despedida são elementos de grande importância.

O suicídio por precipitação é mais comum entre as mulheres.

A pesquisa por medicamentos ou fármacos que possam ter sido usados para drogar a vítima também é item obrigatório, ainda que os antecedentes apontem para o ato extremo.

Se o histórico for de queda acidental, é preciso verificar o que fazia a vítima no momento da queda, se possuía equipamentos de segurança, se houve caracterização de acidente do trabalho, etc.

\section{Exame da trajetória do corpo}

Alguns autores costumam procurar o diagnóstico jurídico da ocorrência baseandose no afastamento do corpo em relação à edificação de onde caiu. Embora esse dado possa realmente ter algum valor, na maior parte das vezes é irrelevante.

\footnotetext{
${ }^{368}$ Ver item 2.6.6: "Vestígios e indícios mistos - sinais de luta".
} 
Inicialmente, é preciso verificar se entre o ponto da queda e o solo não existem anteparos que possam alterar a trajetória (parapeitos, mastros de bandeira, andaimes, etc.). Outro elemento que pode alterar a linha de deslocamento é a existência de fortes ventos. Em um suicídio ocorrido em um edifício situado no Largo São Bento, em São Paulo, o corpo descreveu uma verdadeira parábola. Pressionado pelo vento contra o prédio, caiu sobre uma saliência arquitetônica da mesma edificação, cujo acesso só foi possível com o auxílio do corpo de bombeiros.

Uma vez estabelecido que a queda ocorreu livremente, é conveniente considerar algumas hipóteses:

a) Nas quedas acidentais a trajetória é basicamente vertical, pela ausência de qualquer impulso, e o corpo será encontrado no piso em correspondência com o lugar de onde caiu (figura 29).

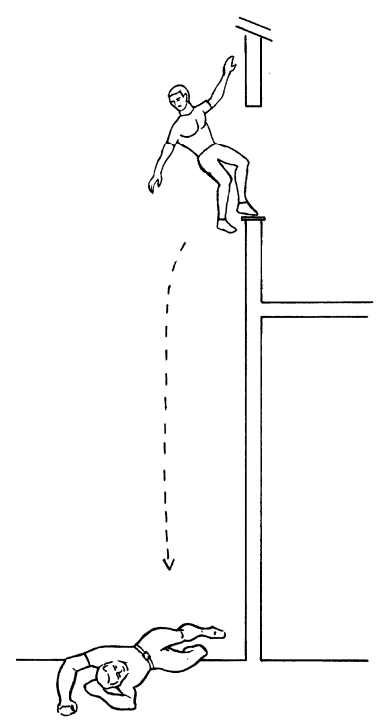

Figura 29 - Queda acidental.

b) Nos suicídios, pode haver impulso inicial ou não. Se a queda ocorreu por uma janela, o normal é a vítima sentar ou apoiar-se no parapeito e dar um pequeno impulso. Em que pesem as opiniões em contrário, nesses casos a trajetória é também vertical e não se diferencia praticamente nada daquela observada na queda acidental (figura 30 - hipóteses A, B e C). 

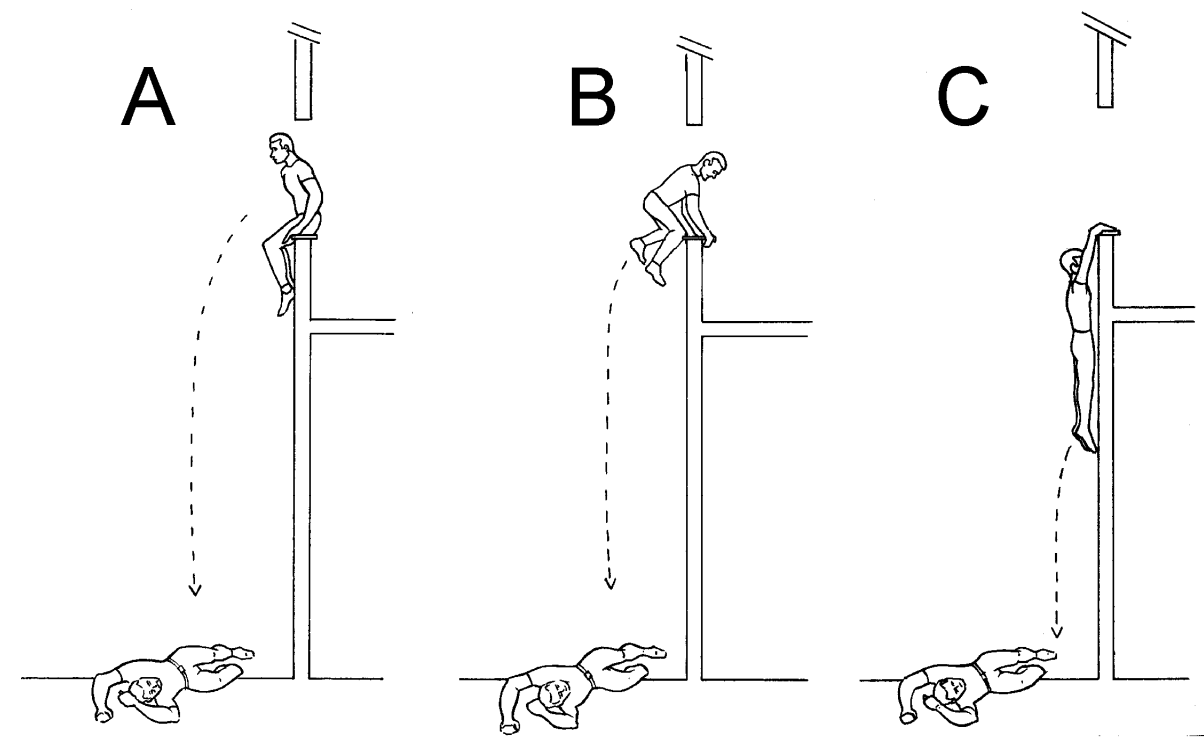

Figura 30 - Hipóteses de suicídio por precipitação sem ou com pequeno impulso inicial.

A única possibilidade de a vítima de suicídio afastar-se grandemente do alinhamento da edificação é a de correr e pular, pela janela ou por sobre o parapeito, com um grande impulso inicial (figura 31 - D), o que é raro. Além disso, é preciso, porém, verificar se as condições físicas do suicida permitiriam a façanha.

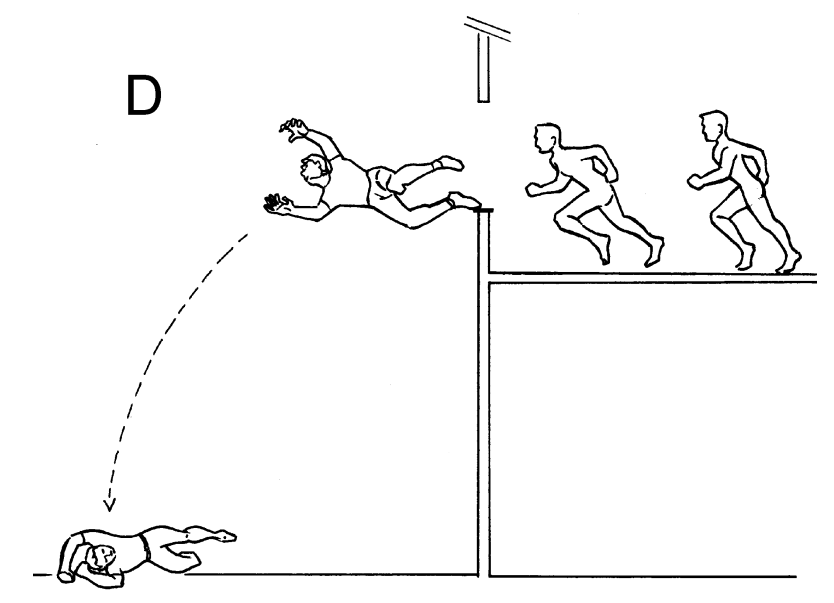

Figura 31 - Suicídio por precipitação com impulso inicial.

c) Na morte de etiologia criminosa, o normal é que também o corpo fique próximo à edificação. É praticamente impossível atirar um corpo humano morto, por uma janela ou por sobre uma mureta de proteção, com impulso suficiente para que ele se afaste significativamente do alinhamento da construção. 
Como regra, o criminoso irá apoiar o corpo no parapeito ou na mureta e atirá-lo para baixo pelos pés (figura $32-\mathrm{E}$ ). $\mathrm{O}$ afastamento será basicamente o mesmo daquele observado em suicídios e quedas acidentais.

A única possibilidade de atirar o corpo da vítima a uma distância maior é a de ser ele arremessado, após balanço, por duas pessoas. Mesmo essa hipótese, porém, reclama algumas condições especiais como uma janela bastante ampla ou uma mureta de proteção baixa (figura $32-\mathrm{F}$ ).
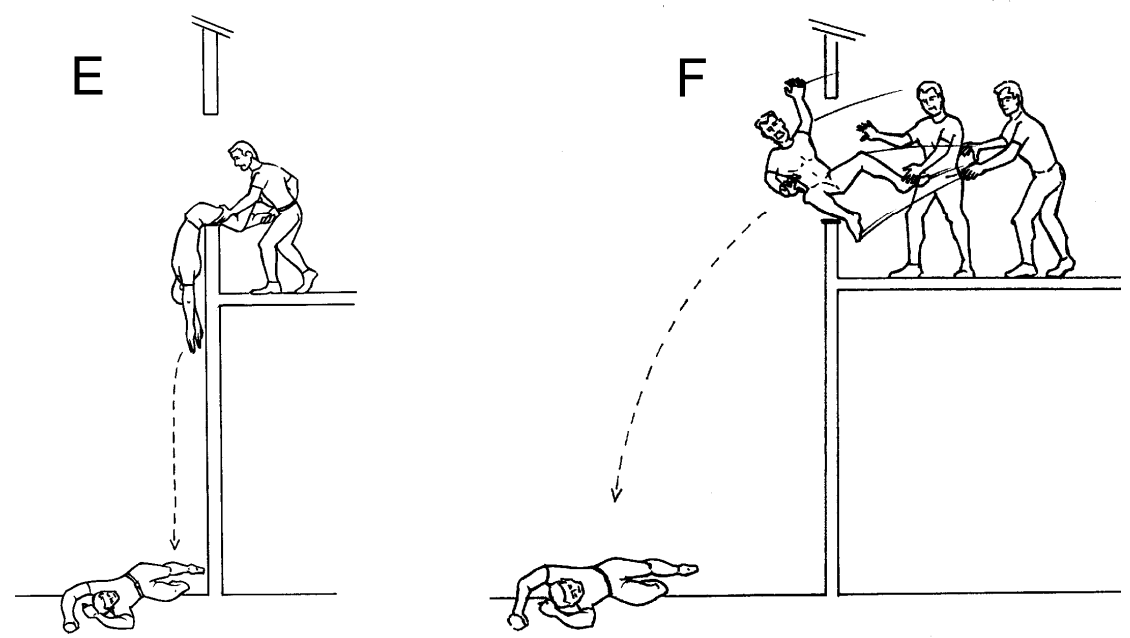

Figura 32 - Hipóteses de simulação de suicídio ou de homicídio por precipitação.

\section{Exame do cadáver}

Tanto o perito, no local, quanto o médico-legista, com mais condições, devem proceder a um minucioso exame da superfície corpórea em busca de lesões incompatíveis com a queda.

Alguns instrumentos contundentes, como barras de ferro ou pedaços de madeira, costumam "imprimir", no corpo da vítima, marcas que denunciam sua forma. Se isso for encontrado, e não houver explicação para tais ferimentos, na queda ou nos antecedentes, a conclusão, ao menos inicial, deve ser pela morte criminosa.

Outra providência indispensável é submeter o corpo ao exame pelos Raios X à procura de projéteis de arma de fogo. 


\subsubsection{Locais de morte a esclarecer ou encontro de cadáver}

Comumente, o Instituto de Criminalística recebe requisições com vistas a proceder ao levantamento de local de morte a esclarecer. Isso ocorre porque a autoridade policial requisitante não conseguiu, pelas informações preliminares, estabelecer a provável etiologia do evento, homicídio, suicídio, morte acidental ou natural e necessita da equipe técnica para fazê-lo.

Embora a grande maioria dos casos esteja ligada a mortes naturais desassistidas, que dispensariam a perícia de local, é conveniente que o técnico realize um exame minucioso de maneira a afastar possível simulação.

Os locais de encontro de cadáver normalmente referem-se a corpos em adiantado estado de decomposição descobertos em locais ermos ou abandonados e que reclamam, como veremos a seguir, alguns cuidados especiais.

\subsubsection{Corpos em adiantado estado de decomposição}

Existe uma concepção errônea entre os peritos no sentido de que o local em que foi encontrado um corpo em adiantado estado de decomposição está prejudicado e que o exame deve ficar exclusivamente a cargo do Instituto Médico-Legal. Em razão desse raciocínio, os laudos são extremamente lacônicos e não trazem mais que uma descrição perfunctória do local e da posição em que foi encontrado o corpo.

Dizemos que a concepção é incorreta porque, na dependência da fase em que se encontre o corpo, mesmo para o Instituto Médico-Legal será muito difícil estabelecer a causa mortis, que na grande maioria das vezes permanece indeterminada.

Além disso, como já tivemos oportunidade de salientar mais de uma vez, os principais indícios e vestígios são recolhidos do local e da posição relativa do corpo. Na maioria esmagadora dos casos, o laudo do Instituto de Criminalística, quando bem elaborado, será muito mais esclarecedor, em termos de diagnóstico jurídico da morte, que o do exame necroscópico. 
O estado em que foi encontrado o corpo, nesse sentido, é irrelevante para o exame do palco dos acontecimentos, que precisa ser feito com a mesma dedicação, como se o fato tivesse ocorrido há algumas horas.

\subsubsection{Ocorrências em ferrovias}

As ocorrências mais comuns em ferrovias são os atropelamentos e as quedas acidentais $^{369}$. Ambas devem ser analisadas com extrema cautela pelo perito em razão da possibilidade de estarem ocultando um crime.

Nos atropelamentos é possível que a vítima tenha sido morta anteriormente e colocada sobre os trilhos para que, colhida por composição ferroviária, venha a ter os ferimentos originais mascarados.

No caso das quedas acidentais é preciso descartar a possibilidade de a vítima ter sido atirada do trem.

Em ambas as hipóteses o exame do local trará poucas evidências. Apenas o exame do cadáver e a prova testemunhal poderão levar alguma luz sobre o fato.

\subsubsection{Locais de explosão e incêndio}

A perícia em locais de explosão ou incêndio é da alçada do Núcleo de Engenharia do Instituto de Criminalística, exatamente pela necessidade de se determinar a natureza e a causa do evento.

Além da explosão ou do incêndio em si, que podem ser acidentais ou criminosos (arts. 250 e 251 do Código Penal), é necessário estabelecer claramente se o evento não foi apenas um pano de fundo para a ocultação de delito mais grave.

Também aqui o exame do(s) cadáver(es) e a prova testemunhal serão de fundamental importância para o diagnóstico da ocorrência.

\footnotetext{
${ }^{369}$ A prática do chamado surfferroviário é responsável por um sem número de mortes entre jovens.
} 


\subsubsection{Acidentes do trabalho}

A perícia em local de acidente do trabalho, da mesma forma, é de atribuição do Núcleo de Engenharia do Instituto de Criminalística e seu objetivo principal é o de verificar se houve dolo ou culpa por parte do empregador no que se refere às normas de segurança do trabalho; daí a possibilidade de simulação.

Valem para esses locais as mesmas recomendações anteriores. 


\section{CONSIDERAÇÕES CRÍTICAS}

\subsection{Preliminares}

No início deste trabalho analisamos o panorama das ciências forenses no Brasil, as principais determinações legais relativas aos peritos e perícias, sua natureza jurídica, seus objetivos, bem como as instituições encarregadas da coleta e produção da prova técnica.

No capítulo II procuramos mostrar a abrangência da perícia, especificamente em relação aos locais de interesse à Justiça Criminal, com foco na coleta inicial da prova no local do fato.

Pergunta-se, agora, se a perícia criminal no Brasil vem atendendo plenamente às suas finalidades. Entendemos que o panorama poderia ser mais auspicioso.

Basta uma simples análise da diversidade de indícios materiais e vestígios que podem ser encontrados nos locais submetidos a exames periciais para verificar que pouquíssimos são os casos em que tais provas são coletadas, preservadas e analisadas.

Além disso, parece haver um consenso no âmbito das carreiras jurídicas no sentido de que a perícia cível é, em geral, bem mais elaborada e conclusiva que a criminal e que esta última vem deixando a desejar.

Partindo desses pressupostos e acrescentando a eles o fato de que poucos são os questionamentos que recaem sobre a prova técnica, poderíamos agrupar as falhas do sistema atual nos seguintes grupos:

- estrutura inadequada dos organismos estatais encarregados da produção da prova pericial;

- preservação inexistente ou inadequada do local;

- despreparo do corpo técnico encarregado da realização dos exames;

- inexistência de uma cadeia de custódia satisfatória;

- ausência de padronização e certificação dos laboratórios envolvidos;

- estrutura fragmentária da perícia; e 
- despreparo das carreiras jurídicas no que toca à apreciação crítica da prova técnica.

\subsection{Estrutura inadequada dos organismos estatais encarregados da produção da prova pericial}

Quando se fala em estrutura, deve-se pensar tanto em termos materiais como humanos.

No que toca à estrutura material é possível afirmar que todos os Institutos de Criminalística e de Medicina Legal deixam muito a desejar.

A ausência de investimentos em equipamentos e tecnologia e a vinculação dos órgãos periciais às estruturas da polícia civil são os fatores principais do descompasso.

Como bem lembra Alberi Espindula, em vários Estados a carência de recursos chega a tal ponto, que em alguns casos faltam reagentes químicos para tipagem sangüínea e luvas cirúrgicas para exame de cadáveres ${ }^{370}$.

Em termos de recursos humanos, o quadro não é diferente. O reduzido número de profissionais e os baixos salários tornam as carreiras periciais pouco atrativas e submetem seus integrantes a jornadas desumanas de trabalho.

Estima-se que a relação ideal de peritos, segundo levantamento feito pela Associação Brasileira de Criminalística, seja de 1 (um) para cada 5000 (cinco mil) habitantes. Tal proporção indica a necessidade de um quadro efetivo cerca de dez vezes superior ao atual, de aproximadamente 3700 (três mil e setecentos) peritos criminais e 2000 (dois mil) médicos-legistas.

A tabela a seguir dá uma idéia do número de peritos criminais em todo o Brasil ${ }^{371}$ :

\footnotetext{
${ }^{370}$ ESPINDULA, Alberi. Perícia criminal e cível: uma visão geral para peritos e usuários da perícia. 2. ed. Campinas, SP: Millennium, 2005. p. 60.

${ }^{371}$ Apud Id. Ibid., p. 57.
} 


\begin{tabular}{|c|c|c|c|c|c|}
\hline \multirow{2}{*}{ Estado } & \multirow{2}{*}{ População } & \multicolumn{2}{|c|}{ Efetivo } & \multirow{2}{*}{$\begin{array}{l}\text { População/ } \\
n^{0} \text { de peritos }\end{array}$} & \multirow{2}{*}{$\begin{array}{c}\text { Quantidade } \\
\text { ideal }\end{array}$} \\
\hline & & Quantidade & $\%$ relativo & & \\
\hline Região norte & 12.900 .704 & 444 & $17 \%$ & $1 / 29.055$ & 2.580 \\
\hline Acre & 557.526 & 24 & $21 \%$ & $1 / 23.230$ & 111 \\
\hline Amapá & 477.032 & 27 & $28 \%$ & $1 / 16.556$ & 95 \\
\hline Amazonas & 2.812 .557 & 33 & $06 \%$ & $1 / 85.229$ & 562 \\
\hline Pará & 6.192 .307 & 163 & $13 \%$ & $1 / 37.989$ & 1.238 \\
\hline Roraima & 1.379 .787 & 53 & $19 \%$ & $1 / 26.033$ & 276 \\
\hline Rondônia & 324.397 & 22 & $34 \%$ & $1 / 14.745$ & 65 \\
\hline Tocantins & 1.157 .098 & 122 & $53 \%$ & $1 / 9.484$ & 231 \\
\hline Região nordeste & 47.741711 & 553 & $06 \%$ & 1/86.332 & 9.548 \\
\hline Alagoas & 2.822 .621 & 39 & $07 \%$ & $1 / 72.374$ & 564 \\
\hline Bahia & 13.070 .250 & 168 & $07 \%$ & $1 / 77.799$ & 2.614 \\
\hline Ceará & 7.430 .661 & 13 & $01 \%$ & $1 / 571.589$ & 1.486 \\
\hline Maranhão & 5.651 .475 & 51 & $05 \%$ & $1 / 110.813$ & 1.130 \\
\hline Paraíba & 3.443 .825 & 53 & $08 \%$ & $1 / 64.977$ & 689 \\
\hline Pernambuco & 7.918 .344 & 171 & $11 \%$ & $1 / 46.306$ & 1.584 \\
\hline Piauí & 2.843 .278 & 10 & $02 \%$ & $1 / 284.327$ & 569 \\
\hline Rio Grande do Norte & 2.776 .782 & 30 & $06 \%$ & $1 / 92.559$ & 555 \\
\hline Sergipe & 1.784 .475 & 18 & $05 \%$ & $1 / 99.137$ & 357 \\
\hline Região centro-oeste & 11.636 .728 & 437 & $19 \%$ & $1 / 26.628$ & 2.327 \\
\hline Distrito Federal & 2.051 .146 & 201 & $49 \%$ & $1 / 10.204$ & 410 \\
\hline Goiás & 5.003 .228 & 104 & $11 \%$ & $1 / 48.107$ & 1.001 \\
\hline Mato Grosso & 2.504 .353 & 85 & $17 \%$ & $1 / 29.462$ & 418 \\
\hline Mato Grosso do Sul & 2.078 .001 & 47 & $12 \%$ & $1 / 44.212$ & 416 \\
\hline Região sudeste & 72.412 .411 & 1.901 & $13 \%$ & $1 / 38.091$ & 14.482 \\
\hline Espírito Santo & 3.097 .232 & 30 & $05 \%$ & $1 / 103.241$ & 619 \\
\hline Minas Gerais & 17.891 .494 & 471 & $13 \%$ & $1 / 37.986$ & 3.578 \\
\hline Rio de Janeiro & 14.391 .282 & 300 & $11 \%$ & $1 / 47.970$ & 2.878 \\
\hline São Paulo & 37.032 .403 & 1.100 & $15 \%$ & $1 / 33.665$ & 7.406 \\
\hline Região sul & 25.107 .616 & 296 & $06 \%$ & $1 / 84.823$ & 5.021 \\
\hline Paraná & 9.563 .458 & 149 & $08 \%$ & $1 / 64.184$ & 1.913 \\
\hline Rio Grande do Sul & 10.187 .798 & 77 & $04 \%$ & $1 / 132.309$ & 2.037 \\
\hline Santa Catarina & 5.356 .360 & 70 & $07 \%$ & $1 / 76.519$ & 1.071 \\
\hline Total geral & 169.799 .170 & 3.631 & $10 \%$ & $1 / 46.763$ & 33.960 \\
\hline
\end{tabular}


Especificamente no Estado de São Paulo, o panorama é ainda pior, se levarmos em consideração o elevado e crescente número de ocorrências policiais e, por conseqüência, de locais a serem atendidos.

Embora em termos materiais os Institutos de Criminalística e Médico-Legal do nosso Estado tenham sido contemplados com aparelhagem mais moderna, não há manutenção adequada ou renovação, e poucos ou nulos são os investimentos em pesquisa.

Quanto ao número de peritos, basta uma análise da evolução do quadro de pessoal para que se tenha uma pálida idéia da deficiência através do tempo.

Os dados a seguir mostram a evolução dos quadros do Instituto de Criminalística de São Paulo em relação ao número de ocorrências ${ }^{372}$ :

\begin{tabular}{|c|c|c|c|}
\hline Ano & Atendimentos & Peritos & Média mensal por perito \\
\hline 1998 & 450.230 & 913 & 47 \\
\hline 1999 & 490.793 & 906 & 52 \\
\hline 2000 & 497.402 & 896 & 53 \\
\hline 2001 & 501.539 & 878 & 54 \\
\hline 2002 & 534.637 & 966 & 57 \\
\hline 2003 & 585.512 & 954 & 63 \\
\hline 2004 & 598.537 & 925 & 67 \\
\hline 2005 & 598.435 & 910 & 69 \\
\hline 2006 & 584.983 & 909 & 65 \\
\hline $2007 *$ & 404.499 & 1.019 & 69 \\
\hline$*$ Os dados de 2007 incluem as ocorrências até o mês de agosto, daí a queda aparente. \\
\hline
\end{tabular}

${ }^{372}$ Dados fornecidos pela Superintendência da Polícia Técnico-Científica do Estado de São Paulo, por cortesia do Superintendente, Dr. Celso Perioli. 

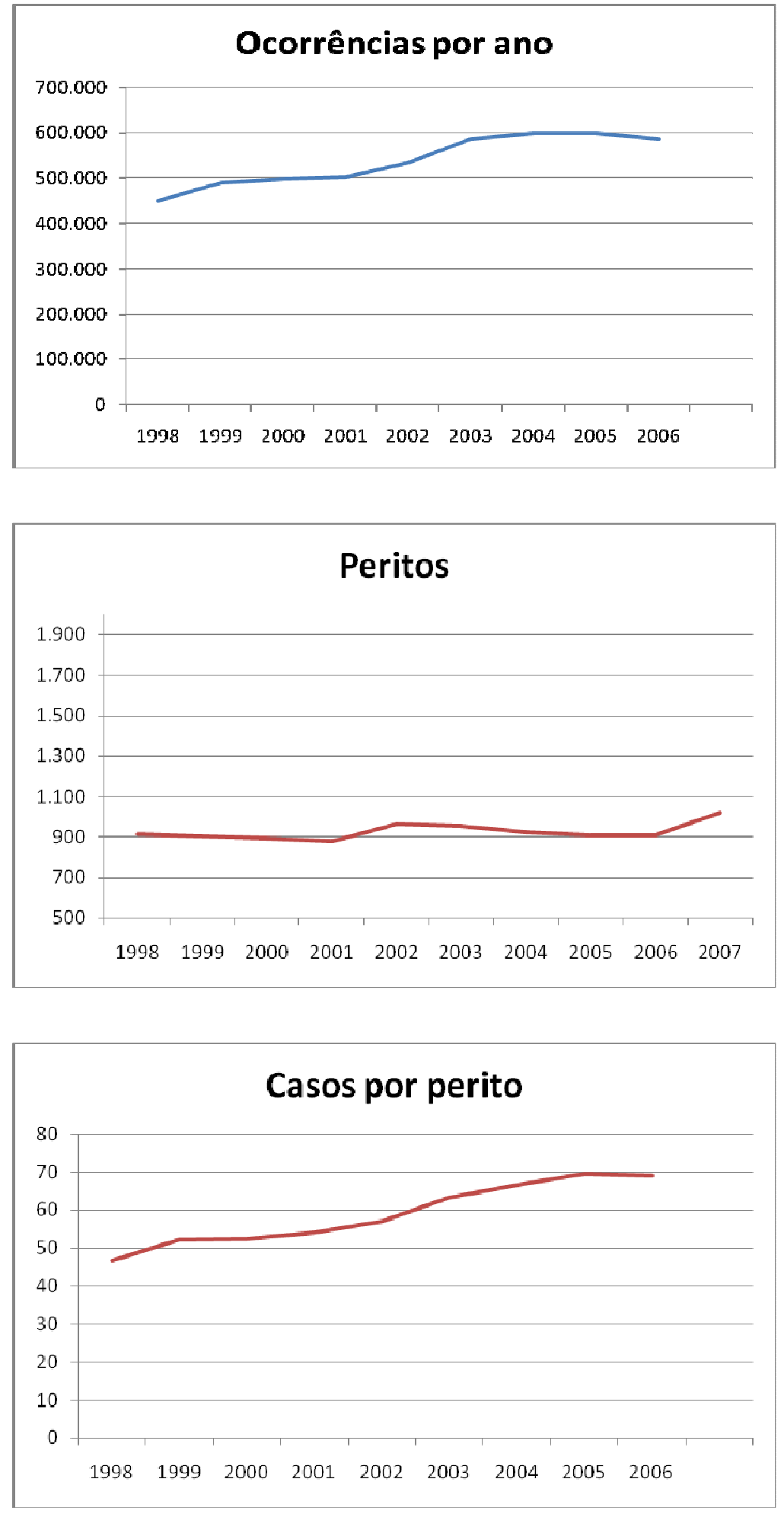

Pode parecer que uma média mensal de 70 (setenta) exames, para cada perito, não é elevada. Entretanto, se levarmos em consideração que um laudo bem elaborado implica no levantamento inicial, em exames complementares, na revelação de fotografias, elaboração de croquis e redação final, para que se possa exigir qualidade é absolutamente necessário diminuir o número de ocorrências. 
A falta de condições materiais e humanas para a realização dos exames periciais faz com que os técnicos tenham que se desdobrar em escalas irracionais de plantão ${ }^{373}$, sem o necessário descanso, ou que atender a inúmeras ocorrências em um mesmo dia, pressionados pela autoridade requisitante e pelo clamor público, que pedem celeridade. Tudo isso conduz à superficialidade e à imperfeição.

A boa perícia, tanto na área criminal como na cível, exige calma e reflexão. Não se pode esperar um exame pericial satisfatório se o técnico encarregado de fazê-lo estiver cansado ou se a estrutura policial insuficiente reclamar a realização de inúmeros outros locais pela mesma equipe.

Outro problema, estreitamente relacionado, é o dos baixos salários, que, de uma maneira geral, atinge o funcionalismo público como um todo e faz com que a maior parte dos peritos criminais e médicos-legistas exerçam outras atividades com o fim de melhor manter suas famílias.

A ausência, na prática, de dedicação exclusiva, além de se refletir na qualidade do trabalho pericial, minimiza o desenvolvimento de pesquisa relacionada.

A prova técnica é a mais compatível com o regime democrático e com o devido processo legal. Na medida em que ela inexiste ou é falha, o resultado inevitável é a impunidade e o aumento da escalada da violência que assola o país.

\subsection{Preservação inexistente ou inadequada do local}

Há consenso no sentido de que o exame do local do fato deve ser o ponto de partida da investigação, daí a necessidade de sua preservação até a chegada da perícia e a realização de um exame atento e minucioso, sem a interferência de estranhos e pelo tempo que o experto julgar necessário.

Muitos casos de repercussão, que poderiam ter sido solucionados por uma perícia bem feita, foram prejudicados pela inoportuna presença da imprensa, de autoridades ou de

\footnotetext{
${ }^{373} \mathrm{Um}$ dos grandes problemas do trabalho policial, incluindo a perícia, é a existência de plantões noturnos alternados com os diurnos. Como é sabido, a privação do sono pode levar a alterações metabólicas, endócrinas, cognitivas, neurais e físicas que, em conjunto, comprometem a saúde e a qualidade de vida do indivíduo. Conquanto existam estudos sobre a privação do sono e queda da produtividade envolvendo todas as profissões e práticas, inclusive esportivas, não há um estudo sério sobre o efeito dessa modalidade no desempenho do policial ou sobre sua estrutura psicológica.
} 
curiosos, que não tendo o conhecimento técnico necessário ou o compromisso com a preservação dos vestígios e indícios, acabaram por destruir preciosas provas em prejuízo da Justiça.

Somente um exame minudente, que envolva não apenas o ambiente imediato como também o mediato, poderá trazer essas preciosas contribuições para a Justiça.

Apesar das advertências expressas, até redundantes, e da importância da matéria, é triste verificar que, na prática, a lei processual penal, idealizada para um país onde o crime deveria constituir a exceção, e não a regra, como vem ocorrendo no Brasil atual, não passa de mera carta de intenções desrespeitada diariamente, quer por descaso das autoridades públicas, quer porque a situação fática chegou a um ponto tão insustentável que os recursos humanos e materiais são ínfimos em face à criminalidade crescente e ignorada pelo Estado.

O fato é que, ao menos em São Paulo, salvo raríssimas exceções, todas elas ligadas a casos de homicídio doloso em que o corpo da vítima encontra-se no local, a autoridade policial (leia-se: o delegado de polícia) não comparece, ficando a tarefa de preservação a cargo da Polícia Militar.

Por outro lado, o despreparo dos policiais civis e militares, mal-instruídos no que concerne à preservação do local, faz com que, às vezes, eles próprios constituam fatores de prejuízo ao cenário pericial $^{374}$.

A preservação do local, conforme prevista pela lei processual, que, inteligentemente, não entra na regulamentação de aspectos operacionais, implica em:

a) interdição rigorosa e célere do local e de suas cercanias;

b) proteção dos vestígios e indícios materiais; e

c) manutenção da interdição e da proteção até o término dos exames periciais.

Os locais externos, pelas suas próprias características e pela curiosidade humana, são os de preservação mais complexa. Inúmeros vestígios de importância, como pegadas, manchas e rastros, além de ficarem expostos à ação de animais ${ }^{375}$ e às intempéries, são freqüentemente desnaturados pelo afluxo de populares.

\footnotetext{
${ }^{374}$ Ver nota 210.

${ }^{375}$ Em conhecido episódio da criminalística paulistana, um cachorro subtraiu e devorou rapidamente um feto que o policial militar havia protegido apenas com uma folha de jornal, destruindo totalmente a prova antes da chegada da perícia. Fatos como esses podem ser facilmente evitados com um mínimo de atenção e profissionalismo.
} 
Em termos práticos, as providências e os cuidados a serem tomados variam de ocorrência para ocorrência.

Arne Svensson \& Otto Wendel $^{376}$ descrevem algumas regras para o primeiro policial que chega à cena do crime:

\begin{abstract}
"É de suma importância para o sucesso da investigação que o policial que primeiro chega à cena do crime não cometa erros, seja por comissão ou por omissão. Tudo emana da cena do crime. Ela provê ao investigador o ponto de partida para procura do ofensor e fornece importantes indícios para os especialistas que chegarão mais tarde. Quem primeiro chega ao local tem o dever de evitar a redução ou destruição de potenciais indícios que poderão, eventualmente, levar à prisão do criminoso".
\end{abstract}

Complementam os renomados autores que é um dever do policial que primeiro chega ao local do crime, qualquer que seja o seu posto, "não destruir ou modificar nada que possa servir para a reconstrução do delito ou que possa ser usado como evidência contra o autor", lembrando que "erros cometidos no interrogatório ou em outros aspectos das investigações preliminares podem ser corrigidos, porém erros cometidos na preservação e exame da cena do crime jamais serão retificados".

Resumidamente, recomendam-se os seguintes cuidados ${ }^{377}$ :

a) ter em mente que prioridade básica é a de salvar e proteger a vida. Embora a preservação do local seja de suma importância, há precedências, como o tratamento de emergência a feridos ${ }^{378}$. O policial deverá ter o cuidado, entretanto, de anotar a posição original da vítima e de outros objetos eventualmente alterados pelo socorro. Dependendo da ocorrência, uma vez encaminhado o ofendido para um hospital, o policial deve providenciar a apreensão de suas vestes para posterior exame;

b) além do socorro, também podem justificar a alteração do local a necessidade de fazer cessar o fato (se o crime estiver sendo cometido); a providência de evacuar o local (que foi invadido por populares antes da chegada da polícia) ou a contingência de ter de

\footnotetext{
${ }^{376}$ SVENSSON, Arne; WENDEL, Otto. op. cit., p. 1 (tradução livre).

${ }^{377}$ Ao especificar os cuidados que devem ser tomados em relação à preservação do local, vamos nos referir ao policial de um modo geral, porque as recomendações aplicam-se tanto aos delegados de polícia e seus agentes, como aos integrantes da polícia militar, que são comumente os primeiros a atender à ocorrência.

${ }^{378}$ Como exemplo, a Lei 5.970 , de 11 de maio de 1973 , exclui da aplicação do disposto nos artigos $6^{\circ}$, inciso I, 64 e 169, do Código de Processo Penal, os casos de acidente de trânsito: "art. $1^{\circ}$ Em caso de acidente de trânsito, a autoridade ou agente policial que primeiro tomar conhecimento do fato poderá autorizar, independentemente de exame do local, a imediata remoção das pessoas que tenham sofrido lesão, bem como dos veículos nele envolvidos, se estiverem no leito da via pública e prejudicarem o tráfego".
} 
evitar um mal maior (como no caso de um incêndio, ou para estancar um vazamento de gás, por exemplo);

c) não se aproximar do local do crime de modo abrupto. Todos os movimentos devem ser calmos e estudados. É preciso considerar todas as hipóteses e jamais ingressar na cena do crime com um diagnóstico preconcebido sobre a ocorrência, pois isso poderia levar a descuido;

d) proteger imediatamente o local da curiosidade de populares, amigos e familiares presentes. Em alguns casos será suficiente bloquear portas para impedir o acesso de estranhos. Em outros, pode ser preciso utilizar cordas, tábuas, fios elétricos e outros materiais retirados de locais não relacionados com o fato objeto da preservação. Em raras oportunidades será necessário solicitar reforço para proceder à conservação do local;

e) a proteção deve ser estabelecida o mais rápido possível, de modo a impedir o desaparecimento de vestígios e indícios materiais importantes;

f) a preservação não deve se restringir à cena do crime, mas estender-se às vias de acesso e fuga do eventual criminoso e a todos os locais mediatos e relacionados;

g) anotar todas as circunstâncias de tempo, como horário do fato, da comunicação à polícia e da chegada ao local. Esses dados poderão ser úteis quando confrontados com as declarações das testemunhas;

h) anotar todos os detalhes possíveis, como estado de portas e janelas (abertas ou fechadas) $)^{379}$ e a posição das chaves, trincos, cadeados e ferrolhos ${ }^{380}$; as lâmpadas que estavam acesas e apagadas ou queimadas; persianas e cortinas abertas ou fechadas; eventuais odores existentes no ambiente, como cigarro, pólvora, gás, perfume ${ }^{381}$; objetos que pareçam incomuns ou que estejam fora do lugar, etc.;

i) manter um registro minucioso de todas as pessoas que entram e saem do cenário, bem como as circunstâncias;

\footnotetext{
${ }^{379}$ A situação das janelas e portas não deve ser alterada antes da chegada da perícia, porque podem abrigar nos batentes e parapeitos vestígios de importância para o esclarecimento do fato.

${ }^{380}$ Carlos Kehdy lembra que as fechaduras podem ter sido abertas por meio de chave falsa, gazua ou caneta de bomba. Nesses casos, não devem ser fechadas com as chaves próprias, porque isso destruiria os vestígios, porventura existentes, do emprego da chave falsa. A melhor solução é desmontar as fechaduras e transportá-las para o laboratório para um exame mais acurado. Os cadeados e ferrolhos devem permanecer abertos ou fechados, da exata maneira como foram encontrados. (KEHDY, Carlos. op. cit., p. 17.)

${ }^{381}$ Lembrar que esses odores poderão não mais estar presentes quando da chegada dos peritos.
} 
j) se o corpo da vítima estiver no local, ainda que sua identificação seja necessária para o início das investigações, o cadáver não deve ser tocado ${ }^{382}$ e nenhum documento ou pertence pessoal removido até o exame detalhado do perito. Embora possa ser difícil, não se deve autorizar atos religiosos ou de reverência ao falecido por amigos e familiares;

1) anotar e procurar preservar, de modo especial, as evidências perecíveis, frágeis, ou que possam ser destruídas antes da chegada dos peritos;

m) despender cuidado especial com relação às armas e munições, principalmente se houver grande afluxo de populares e risco de seu desaparecimento;

n) pegadas, marcas de pneus ou outros sinais peculiares também precisam ser preservados;

o) nada deve ser modificado até a chegada dos peritos, a menos que seja absolutamente imperioso;

p) se imprescindível, antes de inovar a posição de qualquer objeto, deve-se ter o cuidado de verificar se possuía alguma impressão papilar e, em caso positivo, providenciar seu levantamento;

q) anotar a exata posição de cada objeto retirado ou mudado de lugar, para posterior informação aos peritos;

r) em nenhuma hipótese caminhar pelo local ou tocar nos objetos para satisfazer a própria curiosidade ${ }^{383}$;

s) o policial que preserva o local não pode usar o banheiro, abrir torneiras, utilizar toalhas, consumir alimentos, fumar ou atirar objetos no lixo ${ }^{384}$;

t) algumas vezes, suspeitos ou parentes da vítima tentam arrumar ou maquiar o local. Se essa reorganização estiver em andamento quando da chegada ao local, o policial deverá fazê-la cessar imediatamente. Se já foi completada ou se o agente público

\footnotetext{
${ }^{382}$ Não se deve permitir, inclusive, a tomada de impressões digitais do cadáver antes da chegada da perícia. O ato de mexer nas mãos pode mascarar algum vestígio importante como a presença de fragmentos de pele do ofensor sob as unhas (comum em crimes sexuais). Da mesma forma, a tinta utilizada para a retirada das impressões pode prejudicar o exame residuográfico, se este for necessário.

${ }^{383}$ Os autores mencionam o fato, e nós pessoalmente constatamos, em diversas oportunidades, o fato de impressões colhidas no local como indícios promissores, acabarem sendo identificadas como pertencentes aos policiais que atenderam à ocorrência.

${ }^{384}$ Palitos de fósforo, pontas de cigarro e cinzas são vestígios importantes que podem ser mascarados se o policial deixar os seus no local.
} 
desconfiar que houve modificação no estado das coisas, procederá a uma minuciosa inquirição para saber qual era a situação original, informando os peritos;

u) finalmente, o policial deve evitar ser fotografado no local e não deve fornecer informações a respeito do fato, para quem quer que seja, principalmente à imprensa, e muito menos emitir sua opinião sobre a etiologia do evento.

\subsection{Despreparo do corpo técnico encarregado da realização dos exames}

Além da defasagem numérica e dos baixos salários, o efetivo de peritos criminais e médicos-legistas, em grande percentual, deixa muito a desejar no que toca à formação profissional específica.

Isto ocorre, em princípio, porque os cursos de formação técnica, ministrados pelas Academias de Polícia, são muito rápidos e não oferecem subsídios suficientes para que o profissional possa, ab initio, exercer com segurança suas atividades.

É bom lembrar que os peritos criminais, ainda que com formação superior, vêm de áreas heterogêneas do conhecimento humano, cursos cuja finalidade precípua é o exercício de uma determinada profissão e não a realização de perícias, notadamente na área criminal. Mesmo no caso dos médicos-legistas, em que é requisito uniforme a formação médica, poucas são as faculdades que dedicam carga horária significativa à medicina legal.

A essa deficiência de base, soma-se a ausência de uma política pública de qualificação profissional e de investimentos em cursos de atualização e intercâmbios, indispensáveis para que os peritos possam tomar conhecimento dos avanços tecnológicos e se manter atualizados nos diversos ramos da ciência, aplicáveis à criminalística e medicina legal.

Esse despreparo manifesta-se ou pela elaboração de trabalhos lacônicos e incompletos ou pela interpretação imprecisa de vestígios encontrados no local, em prejuízo do esclarecimento de fatos levados à apreciação da Justiça

Os peritos de local (peritos criminais), por exemplo, devem dar muita atenção também ao local mediato. No caso específico de fatos que envolvem o evento morte ${ }^{385}$, por

\footnotetext{
${ }^{385}$ Preferimos utilizar a expressão fatos que envolvem o evento morte porque engloba tanto os irrelevantes penais (acidentes, mortes naturais e suicídios), como crimes previstos em títulos diversos do Código Penal, como, por exemplo, homicídio (doloso ou culposo), infanticídio, participação em suicídio, aborto seguido de morte, latrocínio, crimes contra os costumes seguidos de morte e outros.
} 
vezes o exame se limita a descrever o cadáver, suas vestes e ferimentos, esquecendo-se o técnico de que inúmeros outros vestígios e indícios de extrema relevância podem estar localizados em ambientes contíguos.

Nos crimes cometidos no interior de residências, não raro o autor deixa suas impressões papilares em outros cômodos, esquece documentos pessoais, dispensa os instrumentos do crime, fere-se acidentalmente, produzindo amostras de seu próprio sangue, mantém relações sexuais, com a vítima ou parceiros, gerando manchas de esperma, remexe gavetas com o fito de procurar valores ou coisas específicas, usa os sanitários, abandonando matéria fecal e urina; defeca sobre móveis, cospe, alimenta-se, ingere bebidas alcoólicas, consome drogas, vomita, derruba fios de cabelo, tocos de cigarros e outros materiais que podem ter especial interesse para o deslinde do fato criminoso.

Somente um técnico preparado e atento saberá e poderá colher todos esses elementos, preservando-os para a oportuna apreciação dos organismos encarregados da persecução penal.

Dentro desta perspectiva, ao analisar a estrutura dos relatórios criminalísticos e médico-legais ${ }^{386}$ verificamos que têm apresentado falhas não apenas no conteúdo, mas também no que toca às suas conclusões.

\subsubsection{Laudos de constatação, de orientação e tecnicamente conclusivos}

$\operatorname{Vimos}^{387}$ que, considerada a finalidade, as perícias podem ser de retratação, de interpretação ou opinativas, e que a grande maioria das perícias tem por objetivo apenas a reprodução pura e simples das impressões colhidas pelo técnico, limitando-se à narração detalhada daquilo que foi observado no local, nos instrumentos do crime ou no corpo da vítima, sem a emissão de qualquer conclusão específica, mero "visum et repertum".

Em alguns casos a finalidade da perícia é realmente a de retratação, mas, em outros, considerações de cunho técnico sobre a possível natureza jurídica do evento, que poderiam integrar o trabalho pericial como discussão, são deixadas de lado em prejuízo do esclarecimento do fato.

\footnotetext{
${ }^{386}$ Ver item 1.17: "Relatórios periciais".

${ }^{387}$ Item 1.5: "Classificação das perícias".
} 
O perito de local quase sempre evita materializar suas presunções, primeiro pelo receio (fundado) de a conclusão ser interpretada como incorreta pela Justiça e colocar o subscritor do laudo no banco dos réus, como possível autor do crime de falsa perícia. Em segundo, porque alguns peritos entendem que suas conclusões poderiam invadir o âmbito da tipificação jurídica do fato, afeta aos juízes e promotores de justiça.

Em que pesem as justas ponderações, mesmo nos laudos de retratação, sempre que puder lançar suas conclusões técnicas o perito deverá fazê-lo, não se limitando a uma mera descrição, por vezes perfunctória, dos achados de local.

Não incide em nenhuma incorreção ou imissão em seara alheia, o perito que, depois de minuciosamente examinar um local de morte a esclarecer, concluindo pela ocorrência de suicídio, transmite sua convicção, por exemplo, do seguinte modo: os peritos não encontraram nenhum elemento técnico que permitisse discordar da tese de que a vítima colocou termo à própria vida mediante disparo de arma de fogo na região temporal direita.

No caso de uma cavidade localizada em uma parede ou em um móvel, não basta a conclusão de que foi produzida por projétil de arma de fogo, o que, em princípio, não exige nenhum conhecimento especial. Tendo elementos, o técnico deve ir além e apresentar também um estudo sobre a angulação possível do disparo, o que será bastante útil para firmar ou infirmar futuros depoimentos em juízo.

Ao realizar uma reconstituição, além de transcrever os passos do autor ou de eventual testemunha, em havendo condições, o perito deve demonstrar que a versão apresentada é incorreta, indicando as razões técnicas baseadas nos demais laudos existentes nos autos.

As perícias criminais, sejam produzidas pelo Instituto de Criminalística, sejam elaboradas pelo Instituto Médico-Legal, são, em sua quase totalidade, superficiais, mas é na análise do local que as falhas mostram-se mais gritantes.

Observações a respeito de impressões produzidas por luvas e outros materiais ${ }^{388}$, análise da técnica do passo ${ }^{389}$, marcas e impressões de partes do corpo ${ }^{390}$, análise de fragmentos de pele e anexos, pesquisa e análise de manchas de suor $^{391}$, saliva ${ }^{392}$,

\footnotetext{
${ }^{388}$ Ver item 2.6.4.2: "Impressões de luvas".

${ }^{389}$ Ver item 2.6.4.5: "Marcas e impressões produzidas pelos pés descalços ou por solados".

${ }^{390}$ Ver item 2.6.4.6: "Marcas e impressões de partes do corpo".

${ }^{391}$ Ver item 2.6.4.16: "Manchas de suor".

${ }^{392}$ Ver item 2.6.4.17: "Manchas de saliva".
} 
mecônio ${ }^{393}$ e outras são alguns pálidos exemplos de vestígios que, embora comuns, passam ao largo da consideração pericial sendo literalmente desprezados no Brasil.

\subsection{Inexistência de uma cadeia de custódia satisfatória}

A maioria esmagadora das perícias relacionadas com ilícitos penais (e civis) está condicionada ao exame de determinados locais e com a coleta e posterior análise de evidências materiais ${ }^{394}$ deles provenientes (manchas orgânicas e inorgânicas, fragmentos de tecidos orgânicos ou não, instrumentos, armas próprias e impróprias, etc.).

Por mais que os avanços científicos possam contribuir com as ciências forenses no sentido de aprimorar a capacidade de reunir evidências suficientes para a solução das questões levadas à consideração da Justiça, tais evidências, particularmente aquelas relacionadas com a necessidade posterior de exames laboratoriais, só podem ser aceitas como meios de prova se a coleta, o manuseio e a análise das amostras observarem condições mínimas de segurança de modo a garantir a integridade do material a ser examinado e a idoneidade dos meios empregados.

Como é sabido, "as possibilidades técnicas de realização de uma prova pericial estão sujeitas à qualidade das amostras, o que, em muitos casos, é inerente à própria amostra. Porém, muitas vezes, a qualidade depende dos processos de coleta e de armazenagem destas amostras até a chegada ao laboratório para análises"395.

Por essa razão, todo procedimento realizado entre a comunicação do fato para a autoridade competente e a requisição do exame deve obedecer a um rigoroso sistema de controle denominado cadeia de custódia, que pode ser definido como o conjunto de procedimentos administrativos que certificam a preservação e integridade da amostra durante todos os passos (coleta, recebimento e análise), de maneira a garantir a confidencialidade e a confiabilidade dos resultados.

Lopes, Gabriel e Bareta explicam que a cadeia de custódia:

\footnotetext{
${ }^{393}$ Ver item 2.6.4.18: "Manchas de mecônio".

${ }^{394}$ Estamos usando aqui a expressão "evidências materiais", genericamente, para englobar os vestígios e os indícios materiais encontradiços no local do fato.

${ }^{395}$ BONACCORSO, Norma; PERIOLI, Celso. Centro de custódia. Perito Criminal. Disponível em: <www.peritocriminal.net/artigos/custodia.htm>. Acesso em: $10 \mathrm{dez} .2007$.
} 
"É usada para manter e documentar a história cronológica da evidência, para rastrear a posse e o manuseio da amostra a partir do preparo do recipiente coletor, da coleta, do transporte, do recebimento, do armazenamento e da análise, portanto, refere-se ao tempo em curso no qual a amostra está sendo manuseada e inclui todas as pessoas que a manuseiam,396.

O Instituto de Criminalística de São Paulo, de forma pioneira, tem projeto voltado à criação de um Centro de Custódia, cuja finalidade é a de ser "um organismo centralizador de segurança destinado à guarda de materiais, substâncias, instrumentos e objetos a serem periciados, já periciados ou com perícia em andamento"397.

A iniciativa é louvável e aponta no sentido de uma padronização, mas é preciso mais, porque a preservação da prova não abrange apenas as etapas internas dos organismos encarregados da coleta da prova técnica. É mais abrangente e inclui os procedimentos realizados desde a comunicação do fato para a autoridade competente.

Sem embargo de a maior parte dos autores apontar como etapa inicial da cadeia de custódia a apreensão do material, preferimos retroceder ao momento anterior que é a correta preservação do local ${ }^{398}$. De nada adiantaria, por exemplo, a salvaguarda perfeita da prova do momento de sua coleta até o resultado final de uma análise laboratorial se a mesma foi contaminada ou adulterada no local pelos policiais que atenderam à ocorrência, ainda que involuntariamente.

Outro ponto importante a considerar reside no fato de que, embora a cadeia de custódia seja relevante para a idoneidade de qualquer prova colhida, em determinadas circunstâncias e para algumas espécies de crime sua importância cresce exponencialmente.

É o caso, por exemplo, das amostras de material biológico que devem ser submetidas a posteriores exames laboratoriais para constatação de uso recente de substância entorpecente ou o material colhido das mãos de um suspeito de disparo para o exame residuográfico. Em ambos os casos é imprescindível demonstrar não apenas a origem confiável das amostras, mas também, e principalmente, que não foi possível nenhuma contaminação. Além disso, como tais amostras são, na maioria das vezes, únicas, sua perda pode acarretar prejuízo insanável ao eventual processo.

\footnotetext{
${ }^{396}$ LOPES, Marilu; GABRIEL, M. M.; BARETA, G. M. S. Cadeia de custódia: uma abordagem preliminar. Sistema Eletrônico de Revistas da UFPR. Disponível em: <http://ojs.c3sl.ufpr.br/ojs2/index.php/academica/article/viewFile/9022/6315>. Acesso em: 26 nov. 2007.

${ }^{397}$ BONACCORSO, Norma; PERIOLI, Celso. op. cit.

${ }^{398}$ Ver item 3.3: "Preservação inexistente ou inadequada do local".
} 
Não existe, assim, uma cadeia de custódia geral que abranja todas as provas. Cada espécie de material, cada tipo de vestígio encontrado reclama procedimentos próprios e específicos relacionados com a sua coleta e preservação. Uma cadeia de custódia imaginada para a apreensão de documentos informatizados, por exemplo, é em tudo diferente daquela preconizada para a tomada de amostras biológicas relacionadas às drogas de abuso.

De qualquer modo, existem sempre alguns cuidados e princípios gerais que podem ser elencados visando dar uma maior confiabilidade à perícia. São procedimentos que têm por objetivos padronizar o manuseio das evidências materiais; minimizar a possibilidade de extravio e dano às amostras e materiais e possibilitar a identificação e responsabilização das pessoas envolvidas nos trâmites técnicos.

O quadro a seguir dá uma idéia das principais etapas de uma cadeia genérica de custódia para provas periciais:

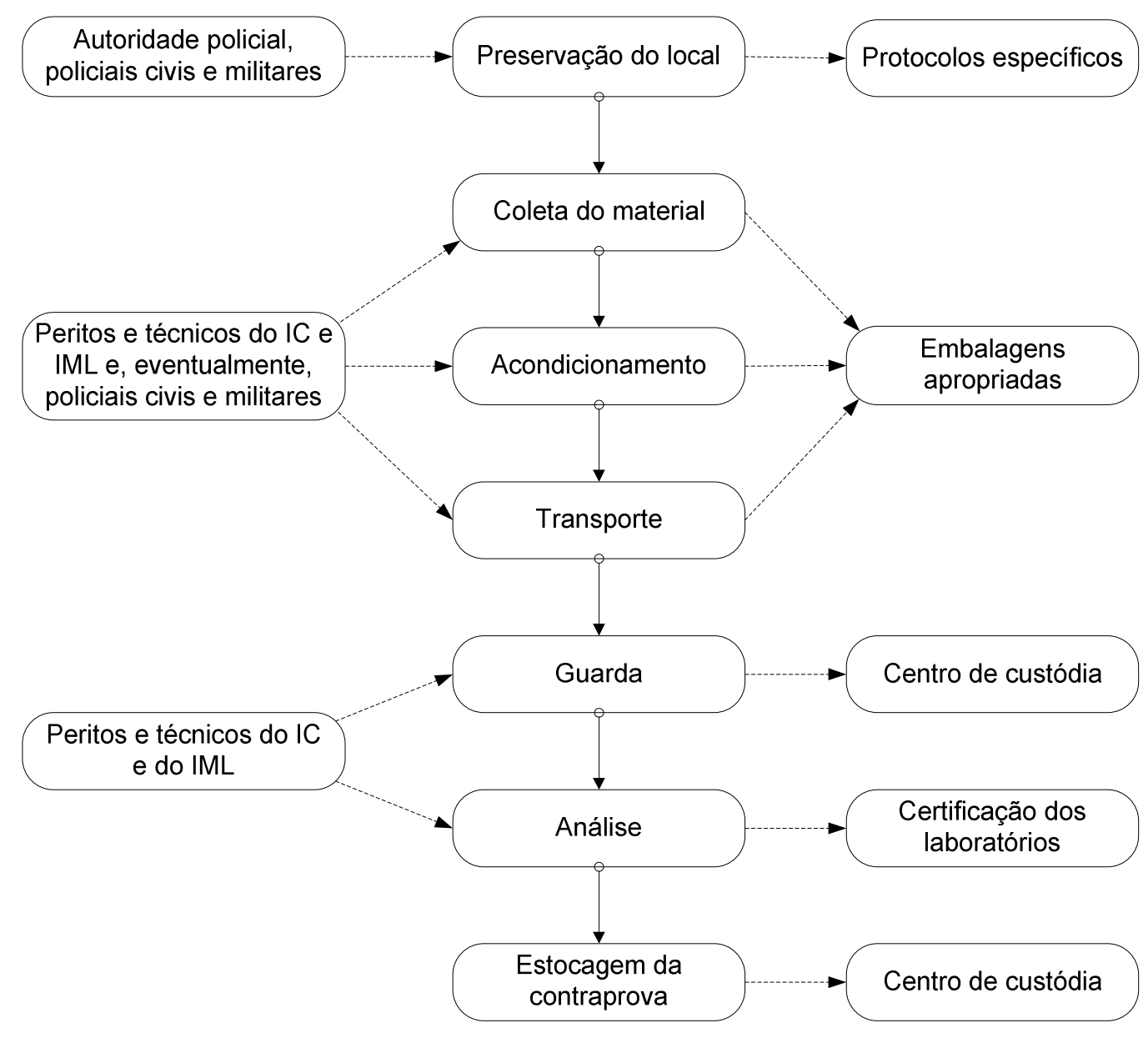


A necessidade da correta preservação do local e os procedimentos básicos a serem adotados já foram discutidos no item 3.3 ("Preservação inexistente ou inadequada do local").

\subsubsection{Coleta, acondicionamento, transporte e guarda}

Os procedimentos de coleta dos diversos materiais e amostras, assim como os cuidados básicos com sua identificação e transporte foram analisados de modo genérico no capítulo II $^{399}$.

As matrizes biológicas (sangue, urina, fezes, pêlos e cabelos, unhas, etc.), vão requerer maior ou menor atenção na dependência das condições em que forem encontradas e dos questionamentos pretendidos.

Especificamente no caso de material biológico para análise de drogas de abuso, além da preservação e integridade da amostra a cadeia de custódia precisa ainda garantir a confidencialidade do exame dada a gravidade de se imputar a alguém o uso de substância entorpecente.

O quadro abaixo resume as principais matrizes biológicas e suas características no que toca à sua eficácia para detecção da utilização de drogas de abuso (doping ou exame para verificação de dependência):

\begin{tabular}{|c|c|c|c|c|}
\hline Matriz & Coleta & Vantagens & Desvantagens & Período de detecção \\
\hline Urina & $\begin{array}{c}\text { Não } \\
\text { invasiva }\end{array}$ & $\begin{array}{l}\text { - Disponibilidade de grandes } \\
\text { volumes de amostra; } \\
\text { - Não necessita de } \\
\text { profissional treinado para a } \\
\text { coleta; } \\
\text { - Alta concentração }{ }^{400} ; \\
\text { - Facilidade de análise; } \\
\text { - Matriz relativamente } \\
\text { simples; } \\
\text { - Correlação com o sangue } \\
\text { de aproximadamente } \\
1: 1,33 \text {. }\end{array}$ & $\begin{array}{l}\text { - Possibilidade de } \\
\text { adulteração da } \\
\text { amostra. }\end{array}$ & $\begin{array}{l}\text { Maconha: } \\
\text { - uso eventual - } \pm 7 \text { dias. } \\
\text { - uso freqüente } - \pm 25 \\
\text { dias. } \\
\text { Cocaína: } \\
\text { - uso eventual - } \pm 3 \text { dias. } \\
\text { - uso freqüente } - \pm 7 \text { dias. } \\
\text { Anfetaminas } - \pm 3 \text { dias. }\end{array}$ \\
\hline
\end{tabular}

\footnotetext{
399“Locais de exames periciais".

${ }^{400}$ A urina é a via normal de eliminação de vários fármacos, que geralmente apresentam-se em altas concentrações, permitido a utilização de técnicas não muito sensíveis.
} 


\begin{tabular}{|c|c|c|c|c|}
\hline & & $\begin{array}{l}\text { - Correlação com o estado } \\
\text { clínico; } \\
\text { - Permite o controle } \\
\text { terapêutico. }\end{array}$ & $\begin{array}{l}\text { - Matriz relativamente } \\
\text { complexa - } \\
\text { dificuldade de } \\
\text { análise; } \\
\text { - Análises mais } \\
\text { demoradas. }\end{array}$ & \\
\hline $\begin{array}{l}\text { Ar } \\
\text { exalado }\end{array}$ & $\begin{array}{c}\text { Não } \\
\text { invasiva }\end{array}$ & $\begin{array}{l}\text { - Detecção de compostos } \\
\text { voláteis como o etanol e } \\
\text { solventes; } \\
\text { - Praticidade - uso do } \\
\text { etilômetro (“bafômetro"); } \\
\text { - Correlação com o sangue } \\
\text { ( } 2100 \text { ml de ar exalado } \\
\text { corresponde à massa de } \\
\text { etanol existente em } 1 \text { ml de } \\
\text { sangue); } \\
\text { - Correlação com o estado } \\
\text { clínico. }\end{array}$ & & $\begin{array}{l}\text { Algumas horas após o uso } \\
\text { (acabou de usar). }\end{array}$ \\
\hline Saliva & $\begin{array}{c}\text { Não } \\
\text { invasiva }\end{array}$ & $\begin{array}{l}\text { - Facilidade de coleta; } \\
\text { - Correlação com } \\
\text { concentração sangüínea } \\
(1: 1) ; \\
\text { - Correlação com estado } \\
\text { clínico; } \\
\text { - Pode ser utilizado para } \\
\text { detecção de etanol, } \\
\text { anfetaminas, cocaína e } \\
\text { canabinóides }^{401} \text {. }\end{array}$ & $\begin{array}{l}\text { - Baixo volume de } \\
\text { amostra; } \\
\text { - Não existe correlação } \\
\text { com o sangue no } \\
\text { momento do } \\
\text { consumo do álcool. }\end{array}$ & $\begin{array}{l}\text { Algumas horas após o uso } \\
\text { (acabou de usar). }\end{array}$ \\
\hline Cabelo & $\begin{array}{l}\text { Não } \\
\text { invasiva }\end{array}$ & $\begin{array}{l}\text { - Possibilidade de análise } \\
\text { retrospectiva e cronológica; } \\
\text { - Estabilidade da amostra. }\end{array}$ & $\begin{array}{l}\text { - Possibilidade de } \\
\text { contaminação. }\end{array}$ & $\begin{array}{l}\text { Meses. Já foi detectada a } \\
\text { presença de cocaína em } \\
\text { múmias peruanas com mais } \\
\text { de } 1000 \text { anos e em múmias } \\
\text { sul-africanas com } 4000 \text { anos. }\end{array}$ \\
\hline Mecônio & $\begin{array}{l}\text { Não } \\
\text { invasiva }\end{array}$ & $\begin{array}{l}\text { - Disponibilidade; } \\
\text { - Possibilidade de } \\
\text { verificação de exposição } \\
\text { fetal. }\end{array}$ & $\begin{array}{l}\text { - Matriz complexa - } \\
\text { dificuldade de } \\
\text { análise. }\end{array}$ & Meses. \\
\hline Unha & $\begin{array}{l}\text { Não } \\
\text { invasiva }\end{array}$ & - Disponibilidade. & $\begin{array}{l}\text { - Baixa concentração } \\
\text { dos fármacos; } \\
\text { - Matriz complexa - } \\
\text { dificuldade de } \\
\text { análise; } \\
\text { - Possibilidade de } \\
\text { contaminação. }\end{array}$ & $\begin{array}{l}\text { Meses, mas necessita } \\
\text { exposição intensa. }\end{array}$ \\
\hline Suor & $\begin{array}{l}\text { Não } \\
\text { invasiva }\end{array}$ & $\begin{array}{l}\text { - Possibilidade de coleta por } \\
\text { adesivos de pele ("patch"); } \\
\text { - Permite o controle } \\
\text { terapêutico. }\end{array}$ & $\begin{array}{l}\text { - Baixa concentração } \\
\text { dos fármacos; } \\
\text { - Matriz complexa - } \\
\text { dificuldade de } \\
\text { análise; } \\
\text { - Possibilidade de } \\
\text { contaminação. }\end{array}$ & Poucos estudos realizados. \\
\hline
\end{tabular}

${ }^{401}$ Os canabinóides podem ser detectados na saliva apenas de modo residual, logo após o consumo da droga. Não há, entretanto, possibilidade de se correlacionar as concentrações da saliva e do sangue, como ocorre com os demais fármacos. 
Como se observa, a multiplicidade de matrizes e a grande variação de características reclamam precaução redobrada quando da coleta, conservação e transporte.

Um cuidado raramente observado e de fundamental importância é o de presenciar a coleta desses materiais. Geralmente, por ser constrangedora a presença física do perito, é entregue ao examinando um frasco para que ali coloque certa quantidade da amostra biológica.

Tal conduta é absolutamente equivocada, pois é possível a substituição da amostra pela de outra pessoa. Existem artefatos à venda na Internet e que podem facilitar esse tipo de substituição, especialmente no que concerne a exames de urina e fezes (figura 33) ${ }^{402}$.

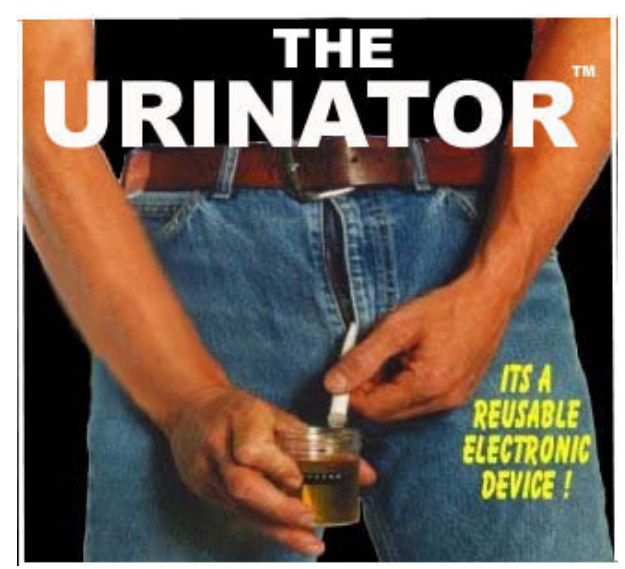

Figura 33 - Artefato utilizado para burlar exames antidoping.

O acondicionamento depende da natureza do material e do exame a ser realizado. As armas e instrumentos de crimes, por exemplo, podem ser manuseados e embalados para transporte ao laboratório da forma descrita no item 2.6.5.1 (“Armas e instrumentos de crimes"), lembrando que os testes para determinação de recenticidade de disparo precisam ser realizados o mais rápido possível.

Para coleta de materiais biológicos devem ser utilizados sacos plásticos e recipientes esterilizados e descartáveis, tomando o perito todos os cuidados para evitar a contaminação.

Uma vez embalados, os materiais e amostras precisam ser corretamente identificados e relacionados para o transporte.

Da identificação deve necessariamente constar:

\footnotetext{
${ }^{402}$ www.urinator.com. Acesso em 20 de novembro de 2007.
} 
- nome do responsável pela preservação do local;

- natureza do material ou amostra;

- local em que foi apreendido ou recolhido;

- data e hora da apreensão ou coleta;

- nome do encarrregado da apreensão ou coleta;

- outras informações pertinentes.

Alguns materiais reclamam cuidados especiais de conservação, como resfriamento ou armazenagem. Outros pedem celeridade na realização dos exames, sob pena de perecimento da amostra.

Os equipamentos de informática e mídia magnética, por exemplo, devem ser guardados e transportados com uma distância mínima de $50 \mathrm{~cm}$ de fontes de calor com temperaturas entre $45^{\circ} \mathrm{C}$ e $75^{\circ} \mathrm{C}$, fontes emissoras de ondas eletromagnéticas como aparelhos de telefonia móvel e rádios VHF portáteis, caixas acústicas, ímãs, etc. O material deve ainda ser posicionado de maneira a não se deslocar verticalmente em função do impacto do veículo de transporte e horizontalmente em decorrência das forças centrípetas

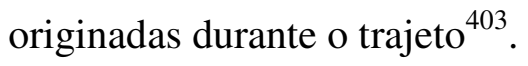

Todos esses procedimentos, enfim, em uma correta cadeia de custódia, precisam ser elencados e padronizados sob a forma de normas internas de serviço.

\subsubsection{Guarda dos materiais - Centro de custódia}

Como já foi mencionado, o Centro de Custódia, apesar de indispensável, é apenas uma etapa da cadeia de custódia. Embora tenha por finalidade "fixar salvaguardas à autenticidade e à integridade das amostras que por ele transitarem" ${ }^{404}$, não abrange o período anterior, compreendido entre a coleta e a remessa do material ao Centro, ou posterior, referente a todas os passos da análise laboratorial. Mesmo assim, é importante etapa da Cadeia de Custódia e local propício para conferência e identificação de possíveis adulterações.

\footnotetext{
${ }^{403}$ SAMPAIO, Marcelo. Normas e procedimentos para a computação forense. Disponível em: <http://www.dpt.ba.gov.br/dpt/web/ICAPInterna.jsp?ModId=70>. Acesso em: 26 nov. 2007.

${ }^{404}$ BONACCORSO, Norma; PERIOLI, Celso. op. cit.
} 
Embora não exista uma padronização a respeito, um Centro de Custódia

minimamente estruturado deve conter:

a) seção de recepção, conferência e devolução de peças, materiais e amostras;

b) seção de seleção, classificação e distribuição de peças, materiais e amostras;

c) depósitos de segurança para a guarda, divididos de acordo com a natureza do material a ser estocado ${ }^{405}$;

d) salas destinadas ao exame de peças, materiais e amostras;

e) protocolos rígidos e específicos para cada uma das etapas;

\begin{abstract}
${ }^{405}$ BONACCORSO \& PERIOLI, por exemplo, idealizaram para um eventual Centro de Custódia a ser implantado no Instituto de Criminalística de São Paulo, cinco depósitos específicos, assim distribuídos:

“a) compartimento para a guarda geral de materiais, oriundos da ocorrência de delitos flagrantes ou não flagrantes, a serem distribuídos, imediata ou mediatamente. Este compartimento demandará maior espaço físico, pois comportará a maior parte do volume dos materiais encaminhados para análises e deverá ter atividade diuturna, uma vez que servirá também ao Núcleo de Toxicologia - entorpecentes que procede, mormente, à análise de materiais oriundos de delitos flagrantes no período noturno. Deverá ainda este compartimento estar aparelhado com equipamentos de refrigeração, próprios para o acondicionamento de materiais destinados, por exemplo, ao Núcleo de Biologia e Bioquímica;

b) compartimento para a guarda provisória de materiais referentes a perícias já em andamento. Este compartimento vem solucionar um antigo problema de guarda de materiais destinados à perícia, por exemplo, recolhidos por Perito Criminal em um local de crime e que por falta de local próprio e seguro para sua guarda em sua unidade deveria mantê-lo junto a si, muitas vezes em sua residência, se não houvesse tempo hábil para conclusão do exame em seu plantão, atitude de boa-fé, mas que romperia a cadeia de custódia, eivando, de antemão, de ilicitude a prova produzida. Outro problema solucionado por este depósito seria aquele no qual, por exemplo, um Perito do Núcleo de Toxicologia que, dado o grande volume de análises em seu plantão, não consegue concluir o exame de 2.000 "papelotes" de cocaína. Ainda nesta linha de exemplificação, se enquadraria o exame de pedras preciosas que demandasse mais de um dia de serviço;
\end{abstract}

c) compartimento para a guarda permanente de materiais analisados em laboratório que, por força de lei, devem ser retidos para contraperícia. Nesta categoria se encaixam materiais de pequeno volume, porém exigem guarda por um período mínimo de 5 anos, guarda especial para substâncias entorpecentes e acondicionamento a $-83^{\circ} \mathrm{C}$ para materiais submetidos, por exemplo, à análise de DNA;

d) compartimento para abrigar materiais de interesse pericial em aguardo de outros para confronto. Nesta categoria de depósito deverão ficar materiais colhidos em locais de crime que não se prestam imediatamente para exames comparativos por falta de outros não presentes na cena do crime, mas em poder, por exemplo, do suposto autor. Este compartimento deverá estar equipado com aparelhos de refrigeração para abrigar, por exemplo, materiais de origem biológica como sangue, vestes com mancha de sangue, esperma, pêlos e cabelos entre outros. Ficarão aqui também depositados projéteis de armas de fogo retirados de corpos de vítimas de crimes sem suspeitos conhecidos. A existência deste depósito aumentará a segurança da guarda destes tipos de materiais que, muitas vezes, ficam na posse e responsabilidade do Perito que os colheu até o surgimento de espécimes para exames de confronto; e

e) compartimento para a guarda de materiais, oriundos da ocorrência de delitos flagrantes ou não flagrantes, já periciados, a serem devolvidos. Este compartimento demandará grande espaço físico, pois deverá abrigar a totalidade dos diversos materiais periciados. Aqui não mais serão exigidos equipamentos especiais, como refrigeradores para o acondicionamento dos materiais, porém deverá oferecer segurança especial, por exemplo, para materiais entorpecentes e armas de fogo, materiais estes que podem ser alvo de furtos pela deficiência do sistema de segurança e pela demora na retirada dos materiais, geralmente oriundos de ocorrências não flagrantes. Há anos têm sido recorrentes as reivindicações dos Peritos Criminais pertencentes ao Núcleo de Toxicologia, instalado ainda hoje no IML central, no sentido de aumentar a segurança da guarda de materiais, pois são eles próprios, pessoalmente, durante seus plantões, os responsáveis pela guarda em uma sala-cofre, onde outros profissionais têm também acesso a ela" (BONACCORSO, Norma; PERIOLI, Celso. op. cit.). 
f) setor de atendimento ao público;

g) sistema de registro, preferencialmente informatizado.

\subsubsection{A Lei $n^{0} 11.690 / 08$ e os centros de custódia}

Não raro, a realidade acaba por exigir providências que as autoridades públicas relutavam em adotar.

É o caso, por exemplo, da Lei n ${ }^{\circ} 11.690$, de 9 de junho de 2008, que introduziu modificações de monta no sistema processual penal, no que toca à produção e apreciação da prova técnica.

O mencionado diploma alterou (entre outros) o art. 159 do Código de Processo Penal para admitir a figura dos assistentes técnicos ${ }^{406}$ e permitir a realização de contraprova, determinado aos Institutos Médico-Legal e de Criminalística, a guarda e a disponibilização do material probatório em ambiente adequado e gravando o mandamento ao órgão oficial com a expressão: "que manterá sempre sua guarda”.

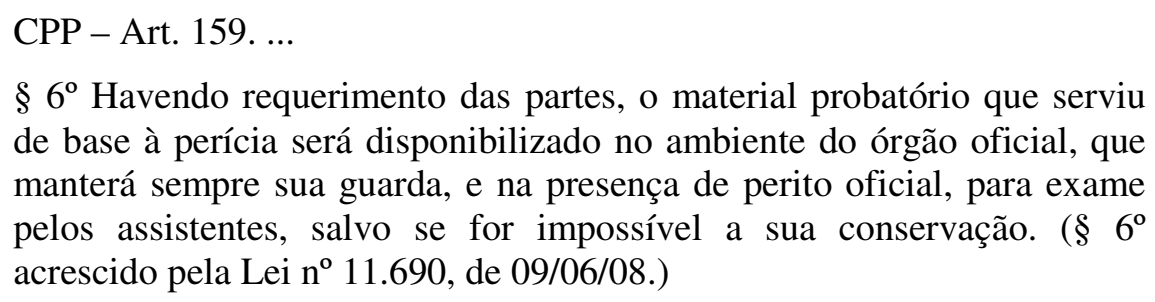

$\S 6^{\circ}$ Havendo requerimento das partes, o material probatório que serviu de base à perícia será disponibilizado no ambiente do órgão oficial, que manterá sempre sua guarda, e na presença de perito oficial, para exame pelos assistentes, salvo se for impossível a sua conservação. $\left(\S 6^{\circ}\right.$ acrescido pela Lei $\mathrm{n}^{\mathrm{o}} 11.690$, de 09/06/08.)

Da leitura do dispositivo deflui a necessidade premente de implementação de um Centro de Custódia que permita conferir dimensão pragmática ao mandamento legal. Sem ele, na grande maioria dos casos, a contraprova será praticamente impossível e a conseqüência previsível será a absolvição de culpados por insuficiência de prova.

\footnotetext{
${ }^{406}$ Ver itens 1.16.2.3: "Assistentes técnicos"; 1.16.2.4: "Momento de admissão dos assistentes técnicos" e 1.16.2.5: "Modo de atuação dos assistentes técnicos".
} 


\subsection{Ausência de padronização do método e de certificação dos laboratórios envolvidos}

Os processos analíticos em geral obedecem a etapas bem definidas, englobando a amostra (coleta, identificação, recepção, registro e armazenamento) e o método analítico utilizado (Procedimento Operacional Padrão - POP).

Os cuidados envolvendo a amostra já foram analisados, restando tecer considerações sobre o método utilizado.

Quando se fala em qualidade e confiabilidade de análises laboratoriais é preciso falar de validação do método, controle e garantia de qualidade ${ }^{407}$.

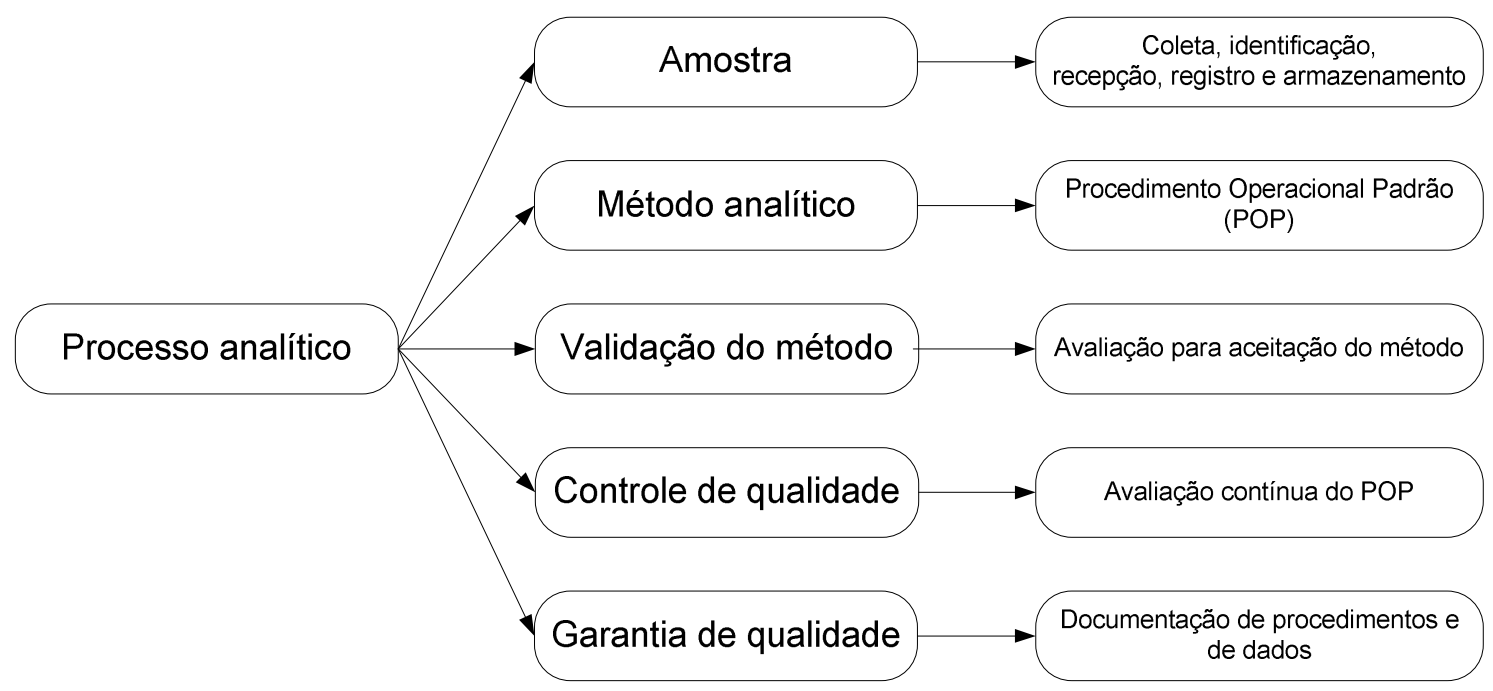

É bem verdade que os protocolos de validação e controle variam na dependência do exame considerado. Existem, na literatura, nacional e estrangeira, inúmeros trabalhos que descrevem sistemas de validação de métodos analíticos, definindo critérios que podem ser seguidos durante seu desenvolvimento, a maioria deles relacionados com as áreas biológica, farmacêutica e química, indicando critérios específicos, enfatizando exatidão, precisão, limites de detecção e quantificação de cada um deles ${ }^{408}$.

Embora o estudo dos métodos de análise das diversas espécies de amostras e materiais fuja ao escopo deste trabalho, é possível traçar parâmetros genéricos que podem

\footnotetext{
${ }^{407}$ Apud Maurício Yonamine, em aula sobre validação de métodos em análises toxicológicas, proferida no Instituto de Química da Universidade de São Paulo, em 05 de setembro de 2006.

${ }^{408}$ BRITO, Natilene Mesquita; AMARANTE JUNIOR, Ozelito Possidônio de; POLESE, Luciana; RIBEIRO, Maria Lúcia. Validação de métodos analíticos: estratégia e discussão. Pesticidas: revista de ecotoxicologia e meio ambiente, Curitiba, v. 13, p. 129-146, jan./dez. 2003. Disponível em: <http://ojs.c3sl.ufpr.br/ojs2/index.php/pesticidas/article/viewFile/3173/2546>. Acesso em: 02 jan. 2008.
} 
ser aplicados ao menos aos laboratórios que tratam de amostras biológicas e que, portanto, são responsáveis pelos exames mais sensíveis dentre aqueles relacionados com a prática de atos passíveis de enquadramento penal.

Os exames analíticos qualitativos e quantitativos, sejam realizados em laboratórios particulares, sejam oriundos de institutos de pesquisa ou de organismos governamentais, têm por objetivo o conhecimento da qualidade e/ou da quantidade de determinadas substâncias presentes em determinada amostra.

Quando os resultados dos exames realizados pelas instituições públicas encarregadas da elaboração das provas periciais (IC e IML) se consubstanciam em laudos periciais, as consequiências são gravíssimas, pois podem implicar na absolvição de um culpado ou na condenação de um inocente $e^{409}$.

Por essa razão, mais do que todos os outros, esses laboratórios necessitam de métodos validados, controlados, garantidos e certificados e, mais ainda, que esses protocolos constem expressamente dos laudos emitidos para que os resultados possam ter um mínimo de credibilidade. Lamentavelmente isso não ocorre e a única garantia passada aos operadores do Direito é a da fé pública gozada pelo técnico encarregado do exame.

\subsubsection{Validação do método analítico}

Validar um método analítico é confirmar, por exame e fornecimento de evidências objetivas, que os requisitos específicos para um determinado uso pretendido foram $\operatorname{atendidos}^{410}$. É estar com o objetivo voltado para a confiabilidade de análise do método.

O processo de validação tem por objetivos diminuir ou controlar os fatores que conduzem à imprecisão ou à inexatidão dos resultados e inclui a especificação dos requisitos do método; a determinação de suas características; a verificação de que tais requisitos podem ser atendidos e uma declaração sobre sua validade.

\footnotetext{
${ }^{409}$ Para se ter uma pálida idéia da importância dos protocolos de validação, consideremos o exame de dosagem alcoólica. O CTB (modificado pela Lei $\mathrm{n}^{\circ}$ 11.705/08), em seu art. 165 (c.c. art. 276), aponta como infração gravíssima o ato de dirigir sob a influência de "qualquer concentração de álcool por litro de sangue", podendo haver configuração do crime do art. 306, se essa concentração for igual ou superior a 6 (seis) decigramas. Nos casos limítrofes, uma pequena variação do método pode significar a caracterização de um delito ou a liberação do investigado.

${ }^{410}$ BARROS, Cleide Bassani de. Validação de métodos analíticos. Revista do Instituto Biológico de São Paulo, São Paulo: Instituto Biológico, v. 64, no 2, p. 175-177, jul/dez, 2002. Disponível em: <www.biologico.sp.gov.br/biologico/v64_2/barros.pdf>. Acesso em: 20 dez. 2007.
} 
Em relação aos métodos clássicos, descritos em compêndios, não é necessário proceder ao processo completo de validação, mas o analista tem por obrigação verificar se as características preconizadas estão sendo obedecidas ${ }^{411}$.

Isso é sempre necessário porque em qualquer processo de análise a ocorrência de erros é inevitável. O que o procedimento de validação busca é o controle do número e da magnitude dos equívocos.

Existem basicamente duas espécies de erros que podem comprometer o processo analítico, os sistemáticos e os indeterminados.

São erros sistemáticos aqueles que, uma vez identificados e desde que constantes, podem ser eliminados com a aplicação de fatores de correção, como, por exemplo, a aplicação do padrão interno. Nesta categoria incluem-se os erros dos instrumentos, presença de impurezas, de operação, de método e pessoais.

Os erros indeterminados são os que ocorrem ao acaso e em razão de causas não perfeitamente conhecidas e controladas. São alterações geralmente irregulares e pequenas, de difícil detecção e controle, como aquelas produzidas por oscilações de umidade, temperatura, iluminação, presença de campos eletromagnéticos e outros.

As características investigadas no processo de validação, a fim de demonstrar o desempenho do método são:

• precisão;

• exatidão;

- linearidade;

- recuperação;

- limite de detecção (LOD);

- limite de quantificação (LOQ);

- seletividade e especificidade;

- robustez;

- estabilidade do analito; e

- faixa de aplicação.

\footnotetext{
${ }^{411}$ Vide Resolução no 899, de 29 de maio de 2003, da ANVISA.
} 


\subsubsection{Precisão}

Precisão é o parâmetro que avalia a proximidade existente entre várias medidas efetuadas em uma mesma amostra ou o grau de concordância entre medidas repetidas da mesma propriedade ${ }^{412}$ e pode ser expressa por intermédio do desvio padrão, variância ou coeficiente de variação (CV) de diversas medidas obtidas em condições de reprodutibilidade $e^{413}$ e repetibilidade $e^{414}$. Normalmente é dado pela seguinte equação:

$$
\mathrm{CV}(\%)=\frac{\mathrm{DP}}{\mathrm{VM} \times 100}
$$

Onde DP é o desvio padrão e VM o valor médio de $n$ replicatas.

Um método será considerado preciso quando apresentar variações aceitáveis para cada hipótese considerada.

\subsubsection{Exatidão}

A exatidão reflete a diferença entre o valor real presente na amostra e o valor obtido na análise realizada. Existem quatro métodos principais, propostos para o estudo da exatidão ${ }^{415}$ :

- o uso de material de referência certificado (MRC) ${ }^{416}$;

\footnotetext{
${ }^{412}$ GONÇALVES, E. B.; CASTRO, I. M. Desenho esquemático para programas de qualidade em laboratório de análises. Ciência e Tecnologia de Alimentos (online), v. 18, $\mathrm{n}^{\circ}$ 1, p. 121-126, 1998. Scielo Brazil Disponível em: <www.scielo.br/scielo.php?script=sci_arttext\&pid=S0101-20611998000100025\& lng=en\&nrm=iso $>$. Acesso em: 05 jan. 2008.

${ }^{413} \mathrm{~A}$ repetibilidade, também conhecida como precisão intra-ensaios, expressa a precisão nas mesmas condições de operação, ou seja, são condições em que os resultados independentes são obtidos utilizando-se frações da mesma amostra com o mesmo método, equipamento, operador, reagentes, dia, condições ambientais e em pequeno espaço de tempo.

${ }^{414} \mathrm{~A}$ reprodutibilidade ou precisão inter-ensaios indica a precisão entre laboratórios, mediante estudos colaborativos usualmente aplicados para padronização de metodologias, ou seja, são condições em que os resultados independentes são obtidos utilizando-se frações da mesma amostra e com o mesmo método, mas com equipamentos, operadores, reagentes, dias e condições ambientais diferentes.

${ }^{415}$ BRITO, Natilene Mesquita; AMARANTE JUNIOR, Ozelito Possidônio de; POLESE, Luciana; RIBEIRO, Maria Lúcia. op. cit., p. 132.

${ }^{416} \mathrm{O}$ processo de avaliação por meio de material de referência consiste em analisar número suficiente de replicatas e comparar os resultados obtidos com o valor certificado. Esse método, quando disponível, deve ser preferido em relação aos demais porque se reporta diretamente aos padrões internacionais. Entretanto, o alto custo e a disponibilidade limitada de matrizes e analitos restringem seu uso (WESLEY, R. J; POCKLINGTON, D.;WALKER, R. F. Analytical quality assurance: a review. The Analyst, v. 116, p. 975990, 1991).
} 
- a comparação do método proposto com um método de referência ${ }^{417}$;

- estudos colaborativos ${ }^{418}$; e

- o uso de ensaios de recuperação na matriz (método mais utilizado) $^{419}$.

A exatidão, na verdade é avaliada em sentido contrário, pela inexatidão, ou seja, pelo afastamento entre os valores esperados e aqueles obtidos:

$$
\text { Inexatidão }(\%)=\frac{\text { Concentração obtida }- \text { concentração real }}{\text { Concentração real }} \times 100
$$

O gráfico abaixo, proposto por Yonamine ${ }^{420}$, ilustra bem a diferença entre os conceitos de precisão e exatidão.

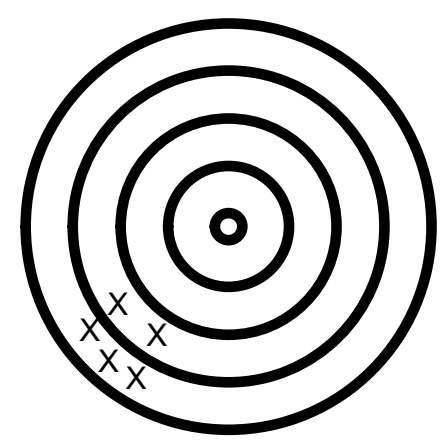

Preciso, mas inexato

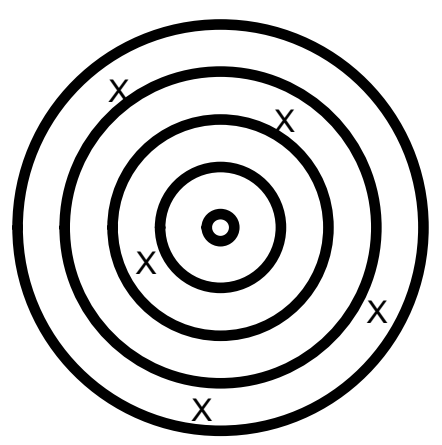

Impreciso e inexato

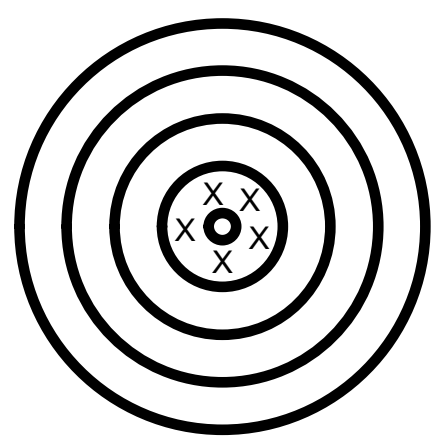

Preciso e exato

\subsubsection{Linearidade - homo e heteroscedasticidade}

A linearidade é a capacidade de um método analítico gerar resultados linearmente proporcionais à concentração do analito dentro de uma faixa analítica especificada. É, em outras palavras, a habilidade de o método analítico produzir resultados que são

\footnotetext{
${ }^{417} \mathrm{Na}$ técnica de comparação cotejam-se os valores obtidos pelo método proposto com os valores obtidos para as mesmas amostras com outro método já validado (método com precisão e exatidão avaliadas). Quanto menor a diferença, mais exata será a técnica.

${ }^{418}$ Estudos colaborativos são raros porque implicam na participação de, no mínimo, cinco laboratórios (sendo oito o número ideal). Além disso, é muito difícil garantir a estabilidade do analito durante todo o período do estudo.

${ }^{419}$ Ver recuperação.

${ }^{420}$ Apresentado em aula sobre validação de métodos em análises toxicológicas, proferida no Instituto de Química da Universidade de São Paulo em 05 de setembro de 2006.
} 
diretamente, ou por uma transformação matemática bem definida, proporcionais à concentração do analito dentro de uma dada faixa ${ }^{421}$.

É determinada pela análise consecutiva de uma série de calibradores (amostras com concentrações variadas e conhecidas do analito) abrangendo a faixa de concentração de interesse (figura 34). Em seguida, determina-se a curva de calibração e o coeficiente de correlação $(\mathrm{CR})$ do processo. O método será considerado linear se o coeficiente de correlação for superior a 0,98 .

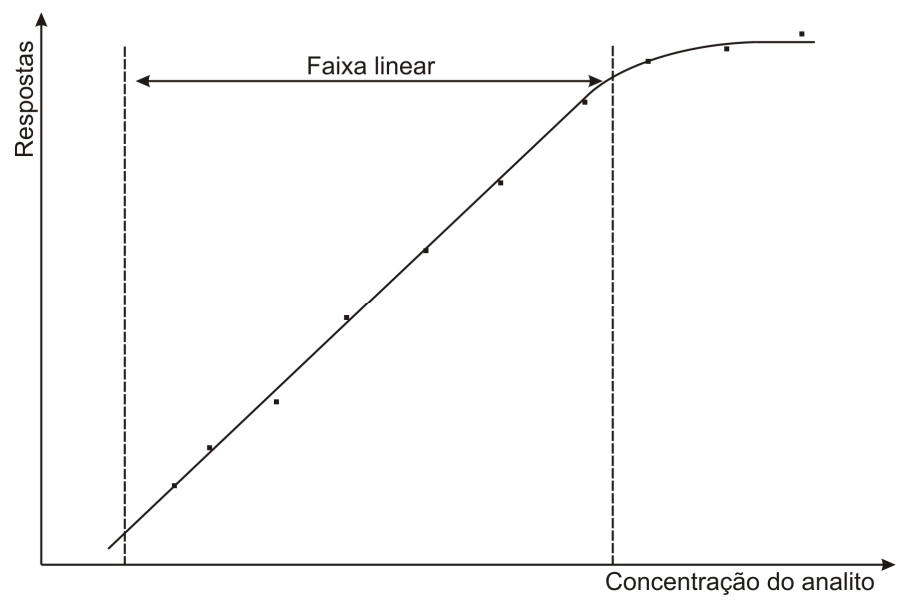

Figura 34 - Linearidade.

Quando se procede à análise estatística de uma determinada amostra, o que se espera é a independência da variância das respostas em relação às diversas concentrações do analito, ou seja, independente da concentração considerada, a variância é sempre constante. Quando isto ocorre, dizemos que a amostra é homoscedástica.

Em alguns casos, porém, a variância não é constante e apresenta tendência de mudar conforme a concentração do analito (figura 35). Quando isso ocorre, os erros deixam de ser aleatórios e passam a relacionar-se com as características das faixas de dados considerados. Essas amostras são ditas heteroscedásticas.

${ }^{421}$ BARROS, Cleide Bassani de. op. cit., p. 176. 


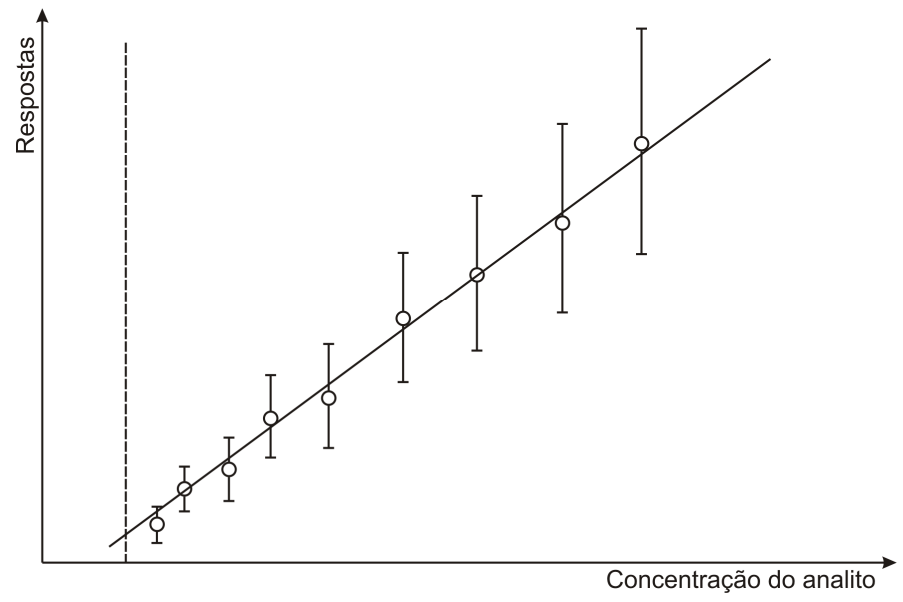

Figura 35 - Heteroscedasticidade.

Para apurar a linearidade do método é preciso afastar a ocorrência ou corrigir sua heteroscedasticidade.

\subsubsection{Recuperação}

A recuperação avalia a eficiência do método de tratamento da amostra. Toda amostra que recebe tratamento para análise indireta (extração, concentração, derivação), deve ter calculado experimentalmente o grau de perda do analito em decorrência desse tratamento.

O teste é realizado adicionando-se uma quantidade conhecida do analito em uma amostra semelhante àquela que se quer analisar ou prepara-se uma amostra sintética de concentração conhecida. Em seguida, realiza-se a análise e verifica-se a proximidade dos valores encontrados.

A taxa de recuperação será calculada pela quantidade encontrada do analito adicionado, dividido pela quantidade do analito adicionado, multiplicada por 100 .

$$
R(\%)=\frac{\text { Quantidade encontrada do analito adicionado }}{\text { Quantidade do analito adicionado }} \times 100
$$




\subsubsection{Limite de detecção (LOD) e de quantificação (LOQ)}

O limite de detecção (LOD) indica a menor concentração ou quantidade de um analito que pode ser identificada por um método analítico com um nível de confiança especificado ou, ainda, que pode ser estatisticamente diferenciado do ruído ${ }^{422}$.

O limite de quantificação (LOQ) indica a menor concentração do analito que pode ser medida com uma precisão especificada.

\subsubsection{Seletividade e especificidade}

A especificidade diz respeito à capacidade de um método produzir resposta apenas para um determinado analito.

A seletividade corresponde à capacidade de um método em determinar o analito na presença de outras substâncias que poderiam interferir na determinação (interferentes $^{423}$.

\subsubsection{Robustez}

Segundo a International Conference on Harmonisation (ICH), a robustez de um método indica a medida de sua capacidade de permanecer inalterado sob pequenas, mas estudadas, variações em seus parâmetros operacionais e ambientais, tais como temperatura, diferentes analistas, procedência dos reagentes, controle do $\mathrm{pH}, \mathrm{etc}^{424}$.

\footnotetext{
${ }^{422}$ Ruídos são interferências relacionadas com os instrumentos, reagentes, método ou mesmo ao próprio analito e que não devem ser consideradas no resultado da análise.

${ }^{423}$ Os interferentes podem ser componentes da matriz biológica, metabólitos, produtos de decomposição ou fármacos eventualmente presentes. No caso de amostras relacionadas com análise toxicológica, a possível presença de nicotina, cafeína, álcool e seus metabólitos, por exemplo, deve ser sempre considerada.

${ }^{424}$ BRITO, Natilene Mesquita; AMARANTE JUNIOR, Ozelito Possidônio de; POLESE, Luciana; RIBEIRO, Maria Lúcia. op. cit., p. 137.
} 


\subsubsection{Estabilidade da amostra}

A estabilidade do analito é a característica que se relaciona com a substância em teste e deve ser considerada tendo em vista as condições de armazenamento (temperatura ambiente, resfriamento, congelamento, transporte, etc.), as propriedades químicas do fármaco considerado, da matriz biológica e dos recipientes utilizados.

Os critérios de aceitabilidade em relação à estabilidade irão depender do objetivo da análise (terapêutica, química, toxicológica, etc.), do processo utilizado, da concentração do fármaco, da matriz biológica e da técnica utilizada.

Para se auferir a estabilidade as amostras devem ser testadas por períodos variados, nunca inferiores a 48 horas, sob condições diferentes e temperatura e umidade, e sempre comparadas com soluções novas do mesmo analito.

Detectando-se problemas de estabilidade, outras condições de estocagem e a adição de estabilizadores químicos são soluções que devem ser consideradas.

\subsubsection{Faixa de aplicação}

Finalmente, a faixa de aplicação indica o intervalo de concentração em que se pode trabalhar com exatidão, linearidade e precisão.

\subsubsection{A necessidade de validação e certificação}

Segundo a ANVISA ${ }^{425}$, os 6 princípios da boa prática analítica são:

1. as medições analíticas devem ser realizadas para satisfazer um requisito acordado entre ambas as partes;

2. as medições analíticas devem ser realizadas utilizando métodos e equipamentos que tenham sido testados de maneira a assegurar que eles atendam ao seu propósito;

\footnotetext{
${ }^{425}$ MOREL, Pierre. Validação de incertezas. Agência Nacional de Vigilância Sanitária. Disponível em: <www.anvisa.gov.br/reblas/cursos_gglas/validacao_incertezas_pierre_2.pdf>. Acesso em: 10 dez. 2007.
} 
3. o pessoal deve ser qualificado e competente para suas tarefas;

4. deve haver avaliações independentes, em intervalos regulares, da performance do laboratório;

5. as medições analíticas realizadas em um laboratório devem ser consistentes com aquelas realizadas em outros laboratórios; e

6. as organizações que realizam medições analíticas devem ter procedimentos de controle e garantia da qualidade.

Cremos que a simples análise das questões levantadas e dos princípios elencados é suficiente para demonstrar a necessidade não apenas da padronização e da validação dos métodos analíticos utilizados pelos laboratórios forenses, como também de uma cristalina publicidade de tais providências.

Além de fazer constar nos laudos os métodos e suas salvaguardas, existe ampla literatura, na área de medições químicas e recomendações publicadas por organizações nacionais e internacionais (ICH Q2B, 1996 ${ }^{426}$; USP 25, 2002 $2^{427}$; FDA, 2000 ${ }^{428}$; NATA, $1998^{429}$; CITAC/EURACHEM， 2002 $2^{430}$; ABNT, NBR， ISO/IEC 17025，2005 INMETRO DOQ-CGCRE-008, 2003 ${ }^{432}$ ), que permitiriam uma rápida e precisa padronização.

Muitas decisões judiciais de importância, especialmente na área penal, são baseadas em resultados de análises químicas qualitativas e quantitativas. Sempre que tais decisões se basearem em resultados analíticos, é imprescindível que se possa ter ao menos

${ }^{426} \mathrm{ICH}$ - International Conference on harmonization of technical requirements for registration of pharmaceuticals for human use - Harmonized Tripartite Guideline, Topic Q2B. Validation of analytical procedures: Methodology. National Institute of Health Sciences. Disponível em: <www.nihs.go.jp/drug/validation/q2bwww.html>. Acesso em: 02 jan. 2008.

${ }^{427}$ USP - United States Pharmacopeia 25/National Formulary 20. (U.S. Pharmacopeial Convention, Rockville, Maryland, 2002).

${ }^{428}$ FOOD AND DRUG ADMINISTRATION - FDA. Guidance for industry. Analytical procedures and methods validation. Center for Drug Evaluation and Research - CDER, 2000. Disponível em: <www.fda.gov/cber/gdlns/methval.pdf>. Acesso em: 02 jan. 2008.

${ }^{429}$ NATA - National Association of Testing Authorities. Technical note 17. Format and content of test methods and procedures for validation and verification of chemical test methods. Australia, 1998.

${ }^{430}$ CITAC/EURACHEM. Guide to quality in analytical chemistry: an aid to accreditation, 2002. Eurachem. A Focus for Analytical Chemistry in Europe. Disponível em: <http://www.eurachem.org/>. Acesso em: 04 jan. 2008.

${ }^{431}$ Estabelece requisitos gerenciais e técnicos para a competência de laboratórios em fornecer resultados de ensaio e calibração tecnicamente válidos. $\mathrm{O}$ atendimento a esta norma significa que o laboratório opera um sistema de gestão da qualidade segundo os princípios da ISO 9001.

${ }^{432}$ INSTITUTO NACIONAL DE METROLOGIA, NORMALIZAÇÃO E QUALIDADE INDUSTRIAL INMETRO. Orientações sobre Validação de Métodos de Ensaios Químicos. DOQ-CGCRE-008. Faculdade de Farmácia da UFMG. Disponível em: <www.farmacia.ufmg.br/lato/downloads/validacao_inmetro.pdf>. Acesso em: 02 jan. 2008. 
alguma indicação quanto à qualidade dos resultados, ou seja, o quanto se pode confiar neles para cada propósito pretendido.

Não é razoável que, enquanto a indústria e a sociedade civil se preocupam, cada vez mais, em apresentar laboratórios e métodos certificados e validados, os organismos públicos encarregados da elaboração das provas periciais permaneçam inertes ao processo.

Urge que se exija dessas instituições a tomada das medidas necessárias, que incluem: o uso de métodos de análise validados, procedimentos internos de controle de qualidade, participação em esquemas de ensaio de proficiência e credenciamento que atendam às exigências das normas estabelecidas (ISO 7025), o estabelecimento de rastreabilidade de seus resultados e medições e a divulgação clara e precisa de tais providências.

O peso que os exames laboratoriais dos Institutos Médico-Legal e de Criminalística têm no conjunto probatório dos processos judiciais é tamanho que não é possível aceitar nada aquém da excelência de seus procedimentos e métodos.

\subsection{Estrutura fragmentária da perícia}

A estrutura fragmentária da perícia não é propriamente um problema em si, mas relaciona-se com o tópico seguinte, o despreparo dos profissionais do Direito para apreciação crítica da prova técnica, porque dificulta a compreensão e a avaliação dos resultados.

Como vimos, alguns exames esgotam-se no levantamento de local enquanto outros dependem de etapas posteriores, geralmente relacionadas a exames complementares, laboratoriais ou não.

Em casos relacionados com crimes contra a pessoa, por exemplo, na dependência da natureza da ocorrência, podemos encontrar os seguintes laudos: de exame do local mediato e imediato; necroscópico; toxicológico; de exame da arma; de comparação balística; residuográfico da vítima e de eventuais suspeitos; de exame das vestes; de possíveis manchas orgânicas e inorgânicas encontradas no local; de DNA em relação a materiais orgânicos provenientes de suspeitos; levantamento de impressões papilares e 
outros, sem falar na possibilidade da existência de laudos complementares e da reprodução simulada dos fatos.

Como esses trabalhos são elaborados por técnicos diversos e em departamentos diferentes dos Institutos Médico-Legal e de Criminalística, além de não apresentar unidade redacional, chegam aos autos em momentos distintos, muitos deles já durante a fase processual, o que torna a compreensão do todo bastante prejudicada.

Um dos grandes problemas relacionados é o da ausência do médico-legista no local do fato. Questão bastante polêmica, a presença do médico, a nosso ver, seria indispensável, não apenas como fator orientador da necropsia, como forma de minimizar as divergências lamentáveis e tão freqüentes na descrição de ferimentos ${ }^{433}$.

Outras incongruências seriam facilmente solucionadas se os diversos técnicos encarregados da elaboração dos exames pudessem reunir-se previamente e apresentar um único trabalho, consolidado e consistente, proposição, reconhecemos, pouco factível em um país onde o crime não constitui a exceção, mas a regra.

\subsection{Despreparo das carreiras jurídicas no que toca à apreciação crítica da prova técnica}

Muito embora, como vimos ${ }^{434}$, a nossa legislação processual, em relação à apreciação da prova pelo juiz, tenha adotado a posição liberatória, segundo a qual o julgador pode ou não aceitar as conclusões do perito baseado em seu livre convencimento (art. 182 do CPP, art. 326 do CPPM e art. 436 do CPC), pouquíssimos são os questionamentos de fato existentes.

É preciso sempre lembrar que a perícia não dita o julgamento, mas apenas o orienta (dictum expertorum nunquam transit in rem judicatum) ${ }^{435}$. O magistrado tem a liberdade de apreciar livremente as conclusões da perícia em relação aos fatos examinados. Não pode, entretanto, rejeitar a perícia arbitrariamente, devendo fundamentar sua rejeição.

Bento de Faria ${ }^{436}$ leciona que, para julgar o exato valor da perícia, o juiz deve:

\footnotetext{
${ }^{433}$ Ver item 3.8.3: "Divergência aparente entre peritos".

${ }^{434}$ Ver item 1.5: "Classificação das perícias".

435“ $O$ parecer dos peritos nunca faz coisa julgada".

${ }^{436} 1960$, p. 276.
} 
a) verificar se os fundamentos científicos nos quais o perito baseou suas conclusões são pacíficos ou admitem contestação;

b) se as deduções se ajustam às regras da lógica;

c) se as conclusões do perito estão em concordância ou divergência com os depoimentos das testemunhas ou com a confissão do acusado;

d) a forma como o perito expõe as suas opiniões.

Em uma análise feita nos julgados do Tribunal de Justiça de São Paulo dos últimos 10 anos, verificamos que são praticamente inexistentes os questionamentos que recaem sobre os fundamentos científicos da perícia ou sobre suas deduções lógicas. No máximo, existem ponderações a respeito de eventuais divergências aparentes ${ }^{437}$, na maioria das vezes sem fundamento, ou sobre eventual contradição com os depoimentos presentes nos autos.

O principal motivo dessa realidade é a precária formação técnica dos profissionais do Direito, que deve ser debitada à grade curricular dos cursos jurídicos. São pouquíssimas as instituições de ensino que têm a preocupação de ministrar aulas relacionadas e, mesmo assim, quando isso ocorre, limitam-se a noções de medicina legal, quando deveriam cuidar da prova técnica como um todo.

Mesmo os concursos jurídicos parecem esquecer a importância do tema. Apenas os certames para Delegado de Polícia realizam provas de medicina legal. Todos os demais passam ao largo da matéria como se a discussão do tema fosse afeta apenas à fase inquisitiva do processo penal.

Esse despreparo leva inexoravelmente a uma submissão das partes e do próprio magistrado às conclusões dos técnicos, submissão essa que se agravou sobremaneira na área penal, até agora, pela ausência de assistentes técnicos ${ }^{438}$.

Mesmo nas perícias de retratação ${ }^{439}$, muitas conclusões de natureza técnica, que poderiam ser exaradas pelos peritos, têm sido deixadas de lado, em prejuízo da própria Justiça, já que os destinatários do trabalho pericial, por não possuírem conhecimento

\footnotetext{
${ }^{437}$ Ver item 3.8.3: "Divergência aparente entre peritos".

${ }^{438}$ A Lei 11.690 , de 9 de junho de 2008, alterou, como vimos, a estrutura do art. 159 do Código de Processo Penal, para admitir a figura dos assistentes técnicos. Acreditamos que, com a novidade, no futuro os questionamentos estarão mais presentes, assim como a necessidade de aprimoramento do trabalho pericial. ${ }^{439}$ Ver item 1.5: "Classificação das perícias".
} 
específico, por vezes não conseguem vislumbrar nas entrelinhas do trabalho apresentado a conclusão final, por mais óbvia que seja.

Nas perícias prospectivas, relacionadas ao exame de situações presentes, mas cujos efeitos deverão ocorrer no futuro, como, por exemplo, o exame de cessação de periculosidade, previsto no art. 775 do Código de Processo Penal, o conhecimento técnico das partes é indispensável, tendo em vista a natureza e a implicação da decisão judicial baseada no laudo ${ }^{440}$.

Também é necessário um conhecimento técnico mínimo para poder apreciar com isenção as perícias contraditórias e saber diferenciá-las da falsa perícia e da divergência aparente entre técnicos.

\subsubsection{Perícia contraditória}

Perícia contraditória é aquela que ocorre quando dois peritos, agindo honesta e conscientemente, não chegam a um ponto de vista comum, por terem entendimentos diversos sobre o objeto do exame.

Embora as ciências formais (lógica e matemática), assim como as ciências factuais naturais (física, química, biologia e outras) admitam menos contradições que as ciências factuais sociais, como o Direito ${ }^{441}$, também permitem, em certas circunstâncias, posições doutrinárias divergentes.

Na perícia contraditória os técnicos, embora discordantes, estão convencidos das conclusões e defendem fundamentadamente suas posições.

São geralmente casos que envolvem uma avaliação subjetiva por parte do perito, como, por exemplo, diagnóstico de patologias mentais, determinação de idade, cessação de periculosidade, constatação de fármaco-dependência e outras.

\footnotetext{
${ }^{440}$ Para que se possa ter uma idéia da importância dessa apreciação, lembramos o recente caso em que um maníaco, liberado por decisão judicial de um hospital psiquiátrico, abusou sexualmente, torturou e matou dois meninos de 13 e 14 anos, na Serra da Cantareira. O crime só ocorreu porque o Magistrado que o libertou não teve condições de formar um juízo crítico sobre o laudo apresentado, que certamente estava incorreto.

${ }^{441}$ Divisão segundo a classificação proposta por MARCONI \& LAKATOS (Metodologia científica. 4 ed. rev. e ampl. São Paulo: Atlas, 2004. p. 28).
} 
Quando isso ocorre, tanto no processo penal como no civil, duas soluções são possíveis:

a) o juiz pode livremente optar por um ou outro trabalho, convencendo-se de que traduz a posição mais correta (CPC, art. 436 e CPP, art. 182); e

b) pode determinar a realização de outra perícia (CPC, arts. 437 a 439 e CPP, art. 181):

CPC

Art. 436. O juiz não está adstrito ao laudo pericial, podendo formar a sua convicção com outros elementos ou fatos provados nos autos.

Art. 437. O juiz poderá determinar, de ofício ou a requerimento da parte, a realização de nova perícia, quando a matéria não lhe parecer suficientemente esclarecida.

Art. 438. A segunda perícia tem por objeto os mesmos fatos sobre que recaiu a primeira e destina-se a corrigir eventual omissão ou inexatidão dos resultados a que esta conduziu.

Art. 439. A segunda perícia rege-se pelas disposições estabelecidas para a primeira.

Parágrafo único. A segunda perícia não substitui a primeira, cabendo ao juiz apreciar livremente o valor de uma e outra.

\section{CPP}

Art. 181. No caso de inobservância de formalidades, ou no caso de omissões, obscuridades ou contradições, a autoridade judiciária mandará suprir a formalidade, complementar ou esclarecer o laudo.

Parágrafo único. A autoridade poderá também ordenar que se proceda a novo exame, por outros peritos, se julgar conveniente.

Art. 182. O juiz não ficará adstrito ao laudo, podendo aceitá-lo ou rejeitálo, no todo ou em parte.

\subsubsection{Falsa perícia}

A falsa perícia, ao lado do falso testemunho, é uma das figuras típicas previstas no art. 342 do Código Penal:

\section{CP - Falso testemunho ou falsa perícia}

Art. 342. Fazer afirmação falsa, ou negar ou calar a verdade, como testemunha, perito, contador, tradutor ou intérprete em processo judicial, ou administrativo, inquérito policial, ou em juízo arbitral:

Pena: reclusão, de um a três anos, e multa. 
$\S 1$ - As penas aumentam-se de um sexto a um terço, se o crime é praticado mediante suborno ou se cometido com o fim de obter prova destinada a produzir efeito em processo penal, ou em processo civil em que for parte entidade da administração pública direta ou indireta.

$\S 2$ o O fato deixa de ser punível se, antes da sentença no processo em que ocorreu o ilícito, o agente se retrata ou declara a verdade.

Crime próprio, o sujeito ativo do delito de falsa perícia é, por óbvio, o perito (e também o tradutor, intérprete ou contador ${ }^{442}$ ), assim caracterizado pela sua atuação oficial, preenchidos os requisitos legais.

Como a oficialidade é a marca registrada da perícia, não pratica o crime o profissional contratado por uma das partes para a apresentação de parecer ou consulta, ainda que tais trabalhos visem, deliberadamente, induzir em erro o perito ou o magistrado.

De forma diferente, entretanto, deve ser tratado o assistente técnico, que pode ser sujeito ativo do crime de falsa perícia, se propositalmente falsear o seu trabalho.

Nesse sentido, Cruz Ferreira lembra que:

"O assistente técnico é profissional dotado de conhecimentos técnicos, indicado pelas partes, no processo civil, encarregado de, juntamente com o perito nomeado pelo juiz, confeccionar a prova pericial. $\mathrm{O}$ simples fato de ter sido indicado pelas partes não tem o condão de eximi-lo da responsabilidade de expor a verdade dos fatos. Ao contrário da testemunha, de quem não se exige nenhuma qualificação legal, o profissional técnico manifesta aptidões e conhecimentos profissionais capazes de levá-lo a uma participação efetiva na produção da prova pericial, que tem natureza dialética. Assim, o perito judicial produz seu trabalho a partir das considerações dos assistentes técnicos, com os quais interage a todo tempo. Dúvida não resta, outrossim, que o trabalho do assistente pode influir no do perito oficial e até mesmo na decisão da causa" ${ }^{\text {"43. }}$

Conclui que, por tais razões, o assistente técnico pode praticar o crime de falsa perícia.

\footnotetext{
${ }^{442}$ Tradutor é aquele que verte para o idioma nacional os textos em língua estrangeira, eventualmente trazidos ao processo. Intérprete é quem serve de intermediário, permitindo a conversação com outras pessoas que não falam o idioma nacional. Contador, acrescentado ao caput do dispositivo pela Lei $\mathrm{n}^{\circ} 10.268$, de 28/08/01, é o técnico encarregado da elaboração dos cálculos judiciais. Embora todos sejam peritos, a lei os distinguiu porque, ao contrário do perito, não produzem prova. Os intérpretes são em tudo equiparados aos peritos pelo art. 281 do CPP.

${ }^{443}$ FERREIRA, Luiz Alexandre Cruz. Falso testemunho e falsa perícia. Campinas, SP: Millennium, 2006. p. 97.
} 
Três são os comportamentos típicos que podem ser atribuídos ao perito (e também ao tradutor, intérprete ou contador):

a) fazer afirmação falsa - o técnico afirma algo que sabe (dolo direto) ou deveria saber (dolo indireto) incorreto, inverídico.

b) negar a verdade - o experto afirma desconhecer algum fato de que, na verdade, tem ciência; e

c) calar a verdade - modalidade omissiva na qual o perito, indagado a respeito de alguma circunstância relacionada ao exame realizado, queda-se silente, deixa de dizer o que sabe e por dever de ofício deveria esclarecer.

Além da ação ou omissão, é indispensável que a conduta ocorra em processo judicial, ou administrativo, inquérito policial, ou em juízo arbitral, sendo atípica, portanto, a falsa perícia cometida em sede de simples sindicância.

"Não confundindo sindicância com processo administrativo e referindose o art. 342 do CP de 1940 apenas a este último, a toda evidência não se pode estender àquela o que a lei define como crime no tocante ao processo administrativo. Trata-se, pois, de fato atípico" (RT 609/320).

Além disso, é indispensável que a falsidade verse sobre fato juridicamente relevante, que possa, ao menos potencialmente, causar dano. Pequenas incorreções que não implicam na validade do trabalho não podem configurar o delito.

O elemento subjetivo é dolo, direto ou indireto, na primeira figura e direto nas demais, não existindo modalidade culposa.

Como asseveramos anteriormente, é temerário identificar em qualquer aparente contradição do trabalho pericial indícios de uma falsa perícia, isso porque é perfeitamente possível que conclusões de peritos diversos sejam divergentes ou mesmo contraditórias, sem que eles tenham propositadamente produzido trabalho mendaz. As discrepâncias podem ocorrer porque os técnicos analisaram de modo diverso o objeto de exame (perícia contraditória) ou porque incidiram em erro (perícia falha). Em nenhuma dessas hipóteses é possível falar em falsa perícia.

"Divergência entre laudos periciais: crime não caracterizado - TJRJ: Falsa perícia. At. 342 do CP: Para a instauração de ação penal por falsa perícia mister se faz a existência de indícios do falseamento da verdade sobre dados objetivos colhidos pelo perito, ou mendacidade no seu parecer, não se configurando como tal a simples disparidade dos 
diagnósticos fornecidos por vários peritos (epilepsia, neurose e psicose maníaco-depressiva), ou o nexo entre o estado de saúde e o trabalho. Concessão da ordem para trancar a ação penal instaurada contra um dos peritos, por falta de justa causa" (RT 584/391).

Se o crime for praticado mediante suborno (delito questuário) ou com a finalidade de obter prova destinada a produzir efeito em processo penal, ou em processo civil em que for parte entidade da administração pública direta ou indireta, a pena é aumentada de um sexto a um terço (art. $\left.342, \S 1^{\circ}\right)$.

$\mathrm{O} \S 2^{\circ}$ do art. 342, prevê que o fato deixa de ser punível se, antes da sentença, o agente se retrata ou declara a verdade. A retratação deve ocorrer no processo em que foi apresentada a perícia viciada.

\begin{abstract}
"Entende a doutrina que o falso testemunho ou a falsa perícia 'é um crime sob condição mas, entenda-se, não sob condição resolutiva, que outra coisa não é a retratação, permitida até o advento da sentença no processo'. Consumando-se com a simples apresentação do laudo ou parecer, mas sobrevindo oportuna retratação, desaparece a punibilidade, cessando em decorrência o processo por falsa perícia ou por testemunho falso" (RJTJESP 123/512).
\end{abstract}

\title{
3.8.3. Divergência aparente entre peritos
}

Existe ainda uma quarta situação, bastante comum, mas que não se confunde com nenhuma das anteriores. É a divergência aparente entre peritos.

Uma questão freqüentemente enfrentada por aqueles que militam no dia-a-dia forense é a divergência, aparente ou real, entre os laudos emitidos pelo Instituto de Criminalística e pelo Instituto Médico-Legal.

Essas discrepâncias são geralmente exploradas pela defesa, especialmente no Tribunal do Júri, onde seguidamente encontramos laudos do IC e IML versando sobre um mesmo delito e onde os jurados, por serem leigos, são facilmente induzidos a erro.

Como visto, a estrutura e a divisão de atribuições entre os dois Institutos encarregados da elaboração das perícias oficiais fazem com que, em relação a uma única ocorrência, diversos relatórios periciais sejam produzidos ${ }^{444}$.

\footnotetext{
${ }^{444}$ Ver item 3.7: "Estrutura fragmentária da perícia".
} 
Não é raro encontrar em um mesmo inquérito policial que versa sobre homicídio, laudos de exame do local, necroscópico, balístico, residuográficos da vítima e suspeitos, exames laboratoriais de manchas encontradas, pesquisa de DNA e reprodução simulada dos fatos. No mínimo, entretanto, iremos ter um laudo relativo ao local e ao cadáver e um laudo de exame necroscópico.

Os peritos criminais têm atribuição para exame do local e instrumentos do crime, podendo efetuar um rápido exame perinecroscópico ${ }^{445}$ para orientação de seus trabalhos, fotografando o corpo na posição em que foi encontrado, bem como todas as lesões externas e vestígios deixados no local do crime, em obediência ao art. 164 do Código de Processo Penal:

\section{CPP}

Art. 164. Os cadáveres serão sempre fotografados na posição em que forem encontrados, bem como, na medida possível, todas as lesões externas e vestígios deixados no local do crime.

Os médicos-legistas, por outro lado, efetuam o exame necroscópico, nas dependências do Instituto Médico-Legal, por vezes sem ter conhecimento da dinâmica do evento, dos comemorativos ${ }^{446}$ ou mesmo dos achados de local.

Essa dicotomia na atuação freqüentemente produz divergências que podem recair sobre:

a) o número de ferimentos;

b) a localização dos ferimentos; e

c) a orientação dos ferimentos.

No que toca ao número de ferimentos, é claro que o médico-legista tem melhores condições para exame do corpo do que o perito criminal, que muitas vezes examina o cadáver rapidamente, na via pública e sem qualquer tipo de assistência. Sendo assim, é bastante compreensível que um exame mais detalhado, realizado sob melhores condições, no Instituto Médico-Legal, venha a revelar ferimentos não observados no local dos fatos.

A localização também pode diferir, já que as lesões podem situar-se em regiões anatômicas limítrofes ou de denominações variadas.

\footnotetext{
${ }^{445}$ Inspeção conjunta do cadáver e do local em que foi encontrado em busca de elementos que possam esclarecer a natureza da ocorrência.

${ }^{446}$ Histórico do evento.
} 
A maior fonte de discordâncias, entretanto, é aquela observada quando na descrição da orientação dos ferimentos, principalmente aqueles produzidos por projéteis de arma de fogo.

Alguns pontos merecem consideração:

Em primeiro lugar, os achados perinecroscópicos dos peritos criminais normalmente são cotejados com os vestígios encontrados no local e comparados com as versões apresentadas pelas testemunhas presentes, enquanto que para os médicos-legistas fica apenas o exame do corpo, absolutamente separado do local em que ocorreu o evento fatal. Isso faz com que o perito criminal apresente a orientação dos ferimentos tendo em mente a dinâmica do evento e não a posição estática do corpo da vítima.

Em segundo lugar, por convenção, o médico descreve os ferimentos de acordo com a posição ortostática ${ }^{447}$, ou seja, analisando-os em relação a um corpo humano em pé, olhando para o infinito, com as pernas juntas, os braços abaixados e as palmas das mãos voltadas para frente, pouco importando a posição real do corpo quando do evento considerado (figura 36).

\footnotetext{
${ }^{447}$ Relativo à ou próprio da postura ereta.
} 


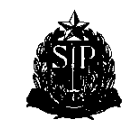

SECRETARIA DA SEGURANÇA PÚBLICA DEPARTAMENTO ESTADUAL DE POLICIA CIENTIFICA INSTITUTO MÉDICO-LEGAL
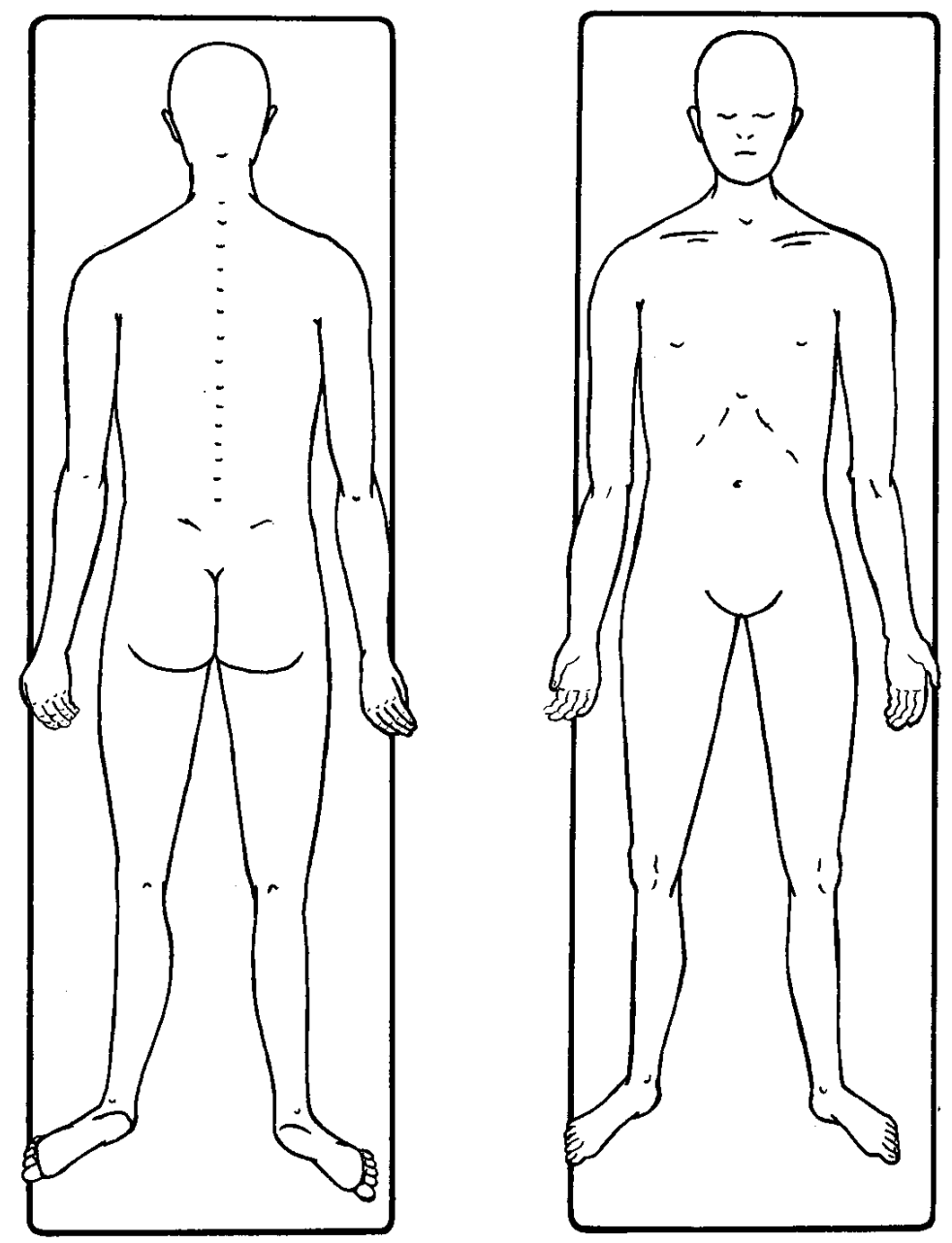

Figura 36 - Formulário padrão do IML - Posição ortostática.

Assim, embora tanto o perito criminal como o médico-legista estejam descrevendo os mesmos ferimentos, o fazem de maneira bastante diversa, dando a impressão de que há uma discordância, quando na verdade ela inexiste.

A figura 36 mostra o impresso-padrão, utilizado pelo Instituto Médico-Legal do Estado de São Paulo, no qual os ferimentos são assinalados pelo médico-legista.

As ilustrações a seguir mostram a razão das aparentes discrepâncias na orientação dos ferimentos.

$\mathrm{Na}$ figura 37, para o perito criminal, o ferimento transfixante foi produzido de cima para baixo, de trás para frente e da esquerda para a direita. O médico-legista, por sua 
vez, irá indicar o mesmo ferimento orientado de baixo para cima, de trás para frente e da esquerda para a direita.

Há, portanto, uma discrepância apenas aparente, quanto à orientação no plano vertical, mas, na verdade, trata-se do mesmo ferimento.

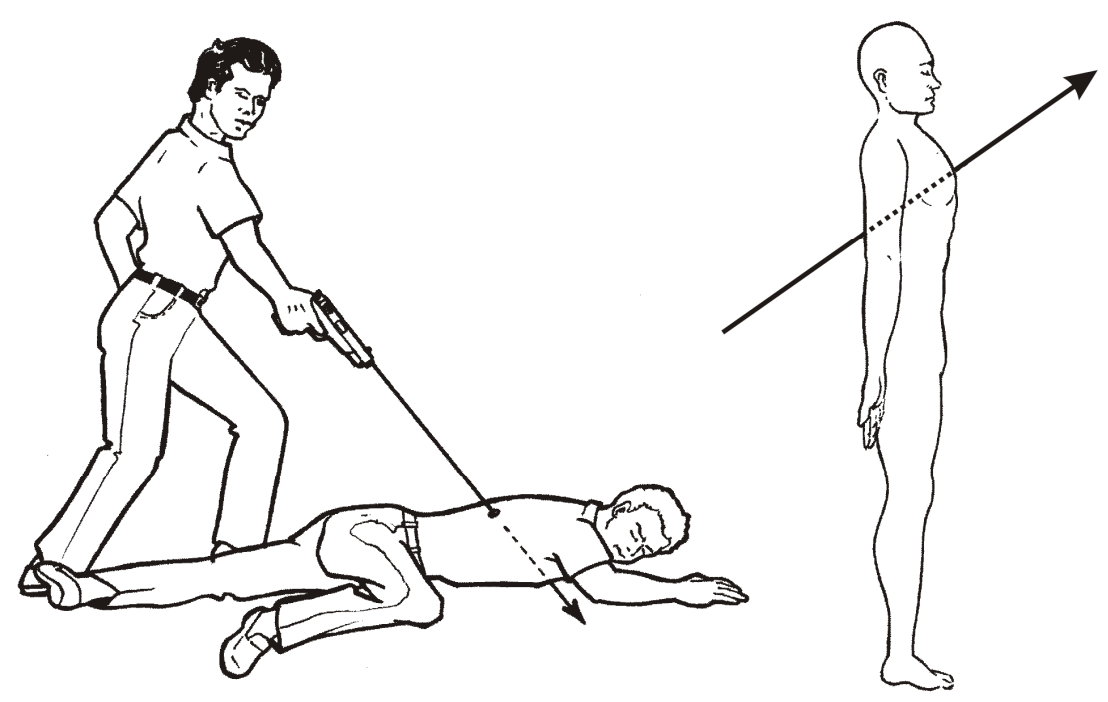

Figura 37 - Divergência aparente entre peritos - orientação do disparo.

Na figura 38, para o perito criminal o disparo foi orientado de trás para frente e de cima para baixo, enquanto o médico-legista aponta um disparo realizado de trás para frente, mas de baixo para cima.
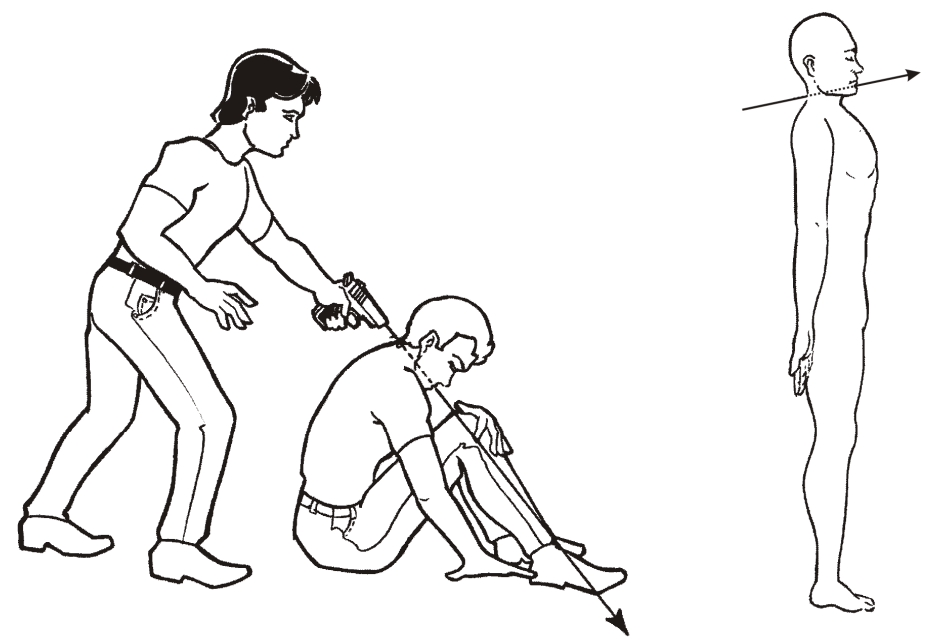

Figura 38 - Divergência aparente entre peritos.

Finalmente, na figura 39, o perito criminal, considerando a dinâmica do evento, descreverá um único disparo, orientado da frente para trás, levemente de baixo para cima 
e da esquerda para a direita (em relação ao atirador), disparo este que produziu dois ferimentos transfixantes, primeiro na mão direita e depois no pescoço (abstraindo a indicação das regiões anatômicas corretas).

O médico-legista trabalhará, em princípio, com a idéia de dois ferimentos isolados, um, transfixante, na mão direita (A), orientado da frente para trás e um segundo ferimento na região do pescoço (B), orientado da direita para a esquerda praticamente na linha horizontal.

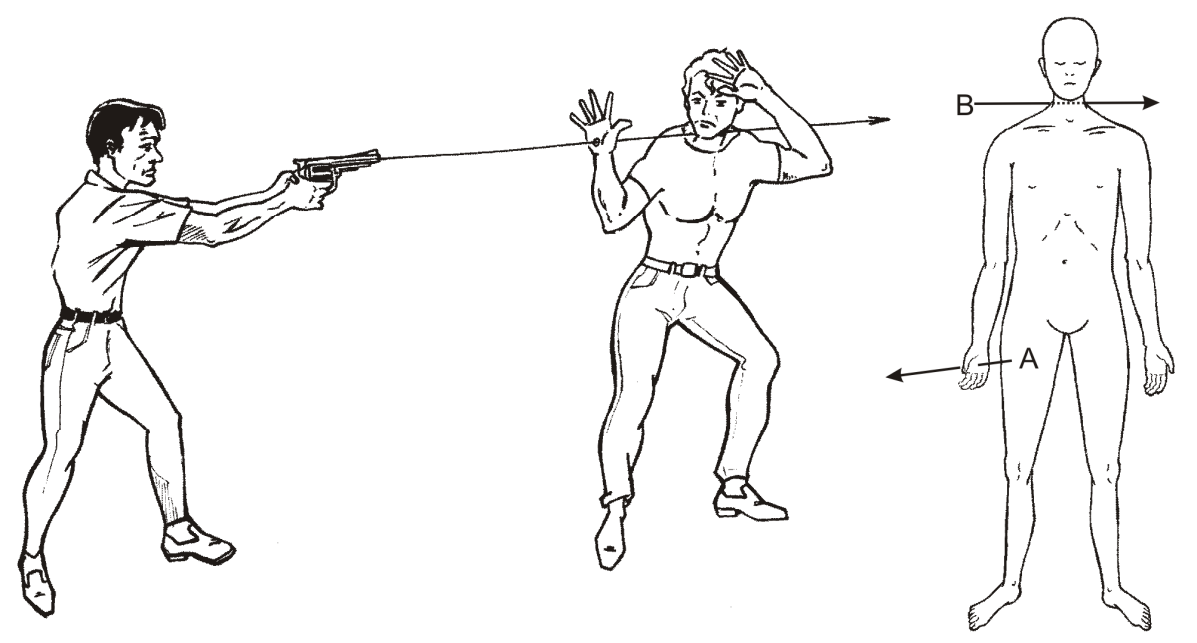

Figura 39 - Divergência aparente entre peritos - orientação e número de disparos.

Concluindo, a maior parte das divergências entre os laudos periciais, se bem analisadas, podem não representar discrepâncias reais, mas apenas maneiras técnicas diferentes de se descrever um mesmo fato.

Tais considerações são necessárias para que os operadores do direito entendam que nem sempre um laudo lacônico ou mal-elaborado corresponde a um profissional desidioso e que a ausência de conhecimento técnico específico pode levar a essa interpretação errônea.

Em muitas ocasiões a falha deve ser debitada mais ao descaso das autoridades públicas e à total ausência de estrutura que a um perito improvidente, muito embora esta última hipótese, lamentavelmente, não esteja fora de cogitação. 


\section{CONCLUSÕES}

A perícia criminal no Brasil não vem atendendo plenamente às suas finalidades. Os exames produzidos tanto pelos Institutos de Criminalística como Médico-Legais são, em sua quase totalidade, superficiais e incompletos, mas é na análise do local que as falhas mostram-se mais gritantes.

Entre as possíveis causas desse panorama pouco auspicioso podem ser apontadas:

- estrutura inadequada dos organismos estatais encarregados da produção da prova pericial;

- preservação inexistente ou inadequada do local;

- despreparo do corpo técnico encarregado da realização dos exames;

- inexistência de uma cadeia de custódia satisfatória;

- ausência de padronização e certificação dos laboratórios envolvidos;

- estrutura fragmentária da perícia; e

- despreparo das carreiras jurídicas no que toca à apreciação crítica da prova técnica.

Entre as medidas possíveis no sentido de aperfeiçoar o sistema de produção da prova técnica, poderiam ser mencionadas:

a) Mudança de foco - A polícia científica ainda é vista em muitas unidades da Federação como um sistema desenhado para atender exclusivamente a Polícia Civil. É preciso alterar essa visão distorcida para dotar os órgãos encarregados da produção da prova técnica de um arcabouço material e humano satisfatório, com uma estrutura compatível de cargos e salários. Somente assim será possível utilizar corretamente o conhecimento técnico dos peritos de forma dinâmica, para que possam interagir não apenas com a autoridade policial, mas com todos os demais destinatários de seu trabalho, em prol do aperfeiçoamento da Justiça.

b) Elaboração de um manual nacional de procedimentos e preservação de local, destinado às Polícias Militar e Civil, assim como a alteração da grade 
curricular das Academias de Polícia no sentido de dedicar maior carga horária à prova pericial. É fundamental que o policial compreenda como são produzidas as provas técnicas e a importância de um local inalterado para que melhor possa exercer suas funções.

c) Estímulo ao aperfeiçoamento do corpo técnico mediante a realização de cursos, palestras, intercâmbio, congressos e incremento das publicações científicas específicas.

É bem verdade que muitos médicos-legistas e peritos criminais têm número significativo de trabalhos científicos publicados, inclusive em revistas internacionais. O que se observa, entretanto, é que tais trabalhos visam mais a formação pessoal específica (particularmente no caso dos médicos) que a área pericial propriamente dita.

Além disso, o número de títulos nacionais é muito reduzido, o que dificulta a divulgação de artigos mais simples, relatos de casos e outras publicações de interesse, mas que não atingem os padrões acadêmicos dos periódicos internacionais.

O mercado editorial não é menos lacônico. Enquanto nos Estados Unidos, em uma rápida pesquisa encontramos mais de 1.000 (mil) títulos relacionados com Criminalística e mais de 7.000 (sete mil) títulos relativos à Medicina Legal, no Brasil encontramos 30 obras de Medicina Legal e 11 de criminalística (não computadas as esgotadas).

A título de exemplo, a única publicação mensal especializada na divulgação das ciências forenses, de grande circulação, a revista Ciência Criminal, foi descontinuada pela Editora Segmento após nove meses porque não alcançou mercado editorial mínimo para a sua edição.

d) Normatização oficial, particularmente no que concerne à cadeia de custódia e mecanismos de preservação de local.

O Ministério da Justiça, por exemplo, até a data de encerramento deste trabalho, mantinha em sua página apenas quatro documentos relativos à padronização dos exames periciais: "Rotinas do Departamento Médico-Legal do Estado do Rio Grande do Sul", "Procedimentos de Coleta de Amostras de Insetos para Fins Forenses", Resolução SSP n 149/99 (Normas para coleta e 
exame de materiais biológicos para identificação humana) e "Padronização de exames de DNA em períciais criminais", todas elas decorrentes de trabalhos e esforços regionais e não do organismo Federal, como seria desejável.

e) Criação de Centros de Custódia regionais para coleta e preservação dos indícios materiais e vestígios.

f) Modificação legislativa no sentido de se passar a exigir padronização e certificação dos laboratórios encarregados da análise da prova técnica.

g) Modificação na estrutura dos Institutos Médico-Legal e de Criminalística para que os laudos sejam elaborados da forma mais englobada possível, evitando, destarte, a realização de trabalhos fragmentados e que possam conter contradições. O ideal seria que todos os encarregados do exame do local e das análises subseqüentes (excluídos os exames complementares), pudessem apresentar redação final única, com conclusões consolidadas.

h) Alteração da grade curricular das Faculdades de Direito de modo a revalorizar as matérias relacionadas com a produção da prova técnica, a fim de melhor instrumentalizar os bacharéis em sua análise.

Concluindo, o ideal seria produzir perícias mais confiáveis, abrangentes e minuciosas e laudos, na medida do possível, conclusivos tecnicamente. Para que isso ocorra, será preciso mudar a mentalidade arcaica, que ainda vê o Processo Penal como uma série de artimanhas baseadas, quase que exclusivamente, em provas testemunhais e que o Poder Público entenda a importância da prova técnica, a mais confiável e aceitável no Estado Democrático de Direito.

A recém-editada Lei $\mathrm{n}^{\mathrm{o}} 11.690$, de 09 de junho de 2008, deu um passo bastante positivo no sentido de modificar esse panorama ao alterar o art. 159 do Código de Processo Penal para admitir a figura dos assistentes técnicos. Essa singela modificação certamente dará ensejo a maior ponderação sobre a chamada prova técnica e, com ela, o aperfeiçoamento dos organismos encarregados de sua produção. 


\section{REFERÊNCIAS BIBLIOGRÁFICAS}

ALMEIDA JR., A. Lições de medicina legal. 4. ed. São Paulo: Nacional, 1957.

; COSTA JR., J. B. de O. e. Lições de medicina legal. 21. ed. rev. e ampl. São Paulo: Nacional, 1996.

ALVES, Rubem. O morto que canta. In: CASSORLA, Roosevelt Moisés Smeke (Org.). Suicídio: estudos brasileiros. Campinas, SP: Papirus, 1991.

AMERICANO, Jorge. Processo civil e comercial no direito brasileiro. São Paulo: Saraiva, 1925.

ANTONIO, Marcelo; COSTA, Sampaio Lemos. Computação forense. 2. ed. Campinas, SP: Millennium, 2003. (Tratado de Perícias Criminalísticas. Organizador: Domingos Tochetto).

ARAGÃO, Ranvier Feitosa. Acidentes de trânsito: aspectos técnicos e jurídicos. 3 ed. Campinas, SP: Millennium, 2003. (Tratado de Perícias Criminalísticas. Organizador: Domingos Tochetto).

ARBENZ, Guilherme Oswaldo. Medicina legal e antropologia forense. Rio de Janeiro: Atheneu, 1988.

BUGLIOSI, Vincent; GENTRY, Curt. Helter Skelter: the true story of the manson murders. New York: W. W. Norton \& Company, Inc., 1994.

CAPEZ, Fernando. Curso de processo penal. 2. ed. São Paulo: Saraiva, 1998.

CALABUIG, J. A. Gisbert. Medicina legal y toxicologia. 5. ed. Barcelona: Masson, 1998.

CROCE, Delton; CROCE JÚNIOR, Delton. Manual de medicina legal. 5. ed., rev. e ampl. São Paulo: Saraiva, 2004.

DIAS, Maria Luiza. O suicida e suas mensagens de adeus. In: CASSORLA, Roosevelt Moisés Smeke (Org.). Suicídio: estudos brasileiros. Campinas: Papirus, 1991.

DOREA, Luiz Eduardo. As manchas de sangue como indício em local de crime. 2. ed. Porto Alegre: Sagra Luzzatto, 1995.

; STUNVOLL, Victor Paulo; QUINTELA, Victor. Criminalística. 2. ed. Porto Alegre: Sagra Luzzatto, 2002. (Tratado de Perícias Criminalísticas. Organizador: Domingos Tochetto).

DORON, Roland; PAROT, Françoise. Dicionário de psicologia. São Paulo: Ática, 1998.

DURKHEIM, Émile. O suicídio: estudo de sociologia. São Paulo: Martins Fontes, 2000. 
ESPINDULA, Alberi. Perícia criminal e cível: uma visão geral para peritos e usuários da perícia. 2. ed. Campinas, SP: Millennium, 2005.

FARIA, Antonio Bento de. Código de Processo Penal. 2. ed. Rio de Janeiro: Record, 1960. v. 1.

FÁVERO, Flamínio. Medicina legal. 11 ed. São Paulo: Martins, 1980.

FERREIRA, Luiz Alexandre Cruz. Falso testemunho e falsa perícia. Campinas, SP: Millennium, 2006.

FISHER, Barry A. J. Techniques of crime scene investigation. $5^{\text {th }}$ ed. Boca Raton, Florida: CRC Press LLC, 1993.

FRANÇA, Genival Veloso de. Medicina legal. 5. ed. Rio de Janeiro: Guanabara Koogan, 1998.

FREUD, Sigmund. Luto e melancolia. Edição eletrônica brasileira das obras completas de Sigmund Freud. Rio de Janeiro: Imago.

GOMES, Hélio. Medicina legal. 33. ed. Atualizada por Hygino de Carvalho Hércules. Rio de Janeiro: Freitas Bastos, 2003.

GORINA, Alfonso Balcells. A clínica e o laboratório. 16. ed. (eletrônica) São Paulo: Medsi, 1996.

GUYTON, Arthur C.; HALL, John E. Tratado de fisiologia médica. 10. ed. Rio de Janeiro: Guanabara Koogan, 2002.

JOBIM, Luiz Fernando; COSTA, Luís Renato; SILVA, Moacyr. Identificação humana. Campinas, SP: Millennium, 2006. (Tratado de Perícias Criminalísticas. Organizador: Domingos Tochetto, v. 2).

KEHDY, Carlos. Manual de locais de crime. 3 ed. São Paulo: Escola de Polícia de São Paulo, 1963. (Coletânea Acácio Nogueira).

LÓPEZ GÓMEZ, Leopoldo. Técnica médico-legal criminalística. Valencia: Editorial Saber, 1953.

MARANHÃO, Odon Ramos. Curso básico de medicina legal. 8 ed., 6 tir. São Paulo: Malheiros Ed., 2002.

MARCONI, Marina de Andrade; LAKATOS, Eva Maria. Metodologia científica. 4 ed. rev. e ampl. São Paulo: Atlas, 2004.

MARQUES, José Frederico. Elementos de direito processual penal. 2. ed. atual. Campinas, SP: Millennium, 2000. v. 2. Instituições de direito processual civil. Campinas, SP: Millennium, 1999. v. 2 e 3. 
MONTIEL SOSA, Juventino. Criminalística. TT I, II e III. México: Limusa, 2000.

MORITA, Tokio; AsSUMPÇÃO, Rosely Maria Viegas. Manual de soluções, reagentes e solventes: padronização, preparação e purificação. São Paulo: Edgard Blücher, 1972.

NEGRINI NETO, Osvaldo. Manual de requisições periciais. Edição eletrônica. São Paulo: APMP, 2002.

Dinâmica dos acidentes de trânsito: análises e reconstruções. Campinas, SP: Millennium, 2003. (Tratado de Perícias Criminalísticas. Organizador: Domingos Tochetto).

O'HARA, Charles E.; OSTEMBURG, James W. Criminalística: a aplicação das ciências físicas na descoberta de crimes. Rio de Janeiro: USAID, 1956.

PLATT, Richard. Crime scene: the ultimate guide to forensic science. $1^{\text {th }}$ ed. New York: Dorling \& Kindersley, 2003.

PORTO, Gilberto. Manual de criminalística. São Paulo: Escola de Polícia de São Paulo, 1960. (Coletânea Acácio Nogueira).

RABELO, Eraldo. Balística forense. 3. ed. Porto Alegre: Sagra Luzzatto, 1996. Contribuição ao estudo dos locais de crime. Revista de Criminalística do Rio Grande do Sul, ano 6, nº 7, 1968. . Curso de criminalística. Porto Alegre: Sagra Luzzatto, 1996.

REIS, Albani Borges dos. Desenho para criminalística e retrato falado. Campinas, SP: Millennium, 2003.

ROJAS, Nerio. Medicina legal. 5. ed. Buenos Aires: El Ateneo, 1953.

SAFERSTAIN, Richard. Criminalistics: an introduction to forensic science. 9th ed. New Jersey: Prentice Hall, 2007.

SANTOS, Moacyr Amaral. Comentários ao Código de Processo Civil: artigos 332 a 475. 6. ed. Rio de Janeiro: Forense, 1994. v. 4.

SAPOLSKY, Robert. Doentes de pobreza. Scientific American Brasil, no 45, p. 74-81, fev. 2006.

SIMONIN, Camille. Medicina legal judicial. Barcelona: Jims, 1962.

SIQUEIRA, Galdino. Curso de processo criminal. 2. ed. São Paulo: Livraria e Officinas Magalhães, 1917.

SLHESSARENKO, Serys. Justificativa da Emenda de Plenário no 9 ao PLC 37, de 2007 Lei n $^{\circ}$ 11.690/08 - Senado Federal. 
SVENSSON, Arne; WENDEL, Otto. Techniques of crime scene investigation. $2^{\text {nd }}$ ed. New York: American Elsevier Publishing Company Inc., 1971.

TEIXEIRA, Wilmes Roberto G. Sexologia forense. Mogi das Cruzes: Universidade Braz Cubas, 1995. Apostila do Curso de Medicina Legal da Universidade Braz Cubas.

THEODORO JÚNIOR, Humberto. Curso de direito processual civil: teoria geral do direito processual civil e processo de conhecimento. 18. ed. Rio de Janeiro: Forense, 1996. v. 1 .

TORNAGHI, Hélio. Curso de processo penal. 6. ed. São Paulo: Saraiva, 1989. v. 1.

TOURINHO FILHO, Fernando da Costa. Processo penal. 10 ed. São Paulo: Saraiva, 1987. v. 4.

ZACHARIAS, Manif; ZACHARIAS, Elias. Dicionário de medicina Legal. 2 ed., rev. e ampl. Curitiba: Ed. Universitária Champagnat, 1991.

ZARZUELA, José Lopes. Anotações de aulas ministradas no curso de formação para peritos criminais, na Academia da Polícia do Estado de São Paulo, em 1981.

. Temas fundamentais de criminalística. Porto Alegre: Sagra DC Luzzatto, 1996.

; MATUNAGA, Minoru; THOMAZ, Pedro Lourenço. Laudo pericial: aspectos técnicos e jurídicos. 1. ed. São Paulo: Ed. Revista dos Tribunais; Sindicato dos Peritos Criminais do Estado de São Paulo, 2000.

WESLEY, R. J; POCKLINGTON, D.;WALKER, R. F. Analytical quality assurance: a review. The Analyst, v. 116, p. 975-990, 1991.

\section{DOCUMENTOS ELETRÔNICOS}

AGÊNCIA NACIONAL DE VIGILÂNCIA SANITÁRIA - ANVISA. Resolução nº 899, de 29 de maio de 2003. Disponível em: <www.anvisa.gov.br>. Acesso em: 28 out. 2008.

BARROS, Cleide Bassani de. Validação de métodos analíticos. Revista do Instituto Biológico de São Paulo, São Paulo: Instituto Biológico, v. 64, nº 2, p. 175-177, jul/dez, 2002. Disponível em: <www.biologico.sp.gov.br/biologico/v64_2/barros.pdf>. Acesso em: 20 dez. 2007.

BEIGUELMAN, Bernardo. Genética de populações humanas. Disponível em: $<$ http://lineu.icb.usp.br/ bbeiguel/Genetica\%20Populacoes/Cap.0.pdf>. Acesso em: 10 dez. 2006.

BONACCORSO, Norma; PERIOLI, Celso. Centro de custódia. Perito Criminal. Disponível em: <www.peritocriminal.net/artigos/custodia.htm>. Acesso em: 10 dez. 2007. 
BRITO, Natilene Mesquita; AMARANTE JUNIOR, Ozelito Possidônio de; POLESE, Luciana; RIBEIRO, Maria Lúcia. Validação de métodos analíticos: estratégia e discussão. Pesticidas: revista de ecotoxicologia e meio ambiente, Curitiba, v. 13, p. 129-146, jan./dez. 2003. Disponível em: $<$ http://ojs.c3sl.ufpr.br/ojs2/index.php/pesticidas/article/viewFile/3173/2546>. Acesso em: 02 jan. 2008.

CANIBAL alemão é condenado à prisão perpétua em última instância. Terra. Disponível

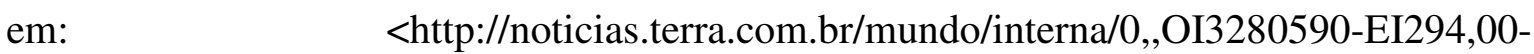
Canibal+alemao+e+condenado+a+prisao+perpetua+em+ultima+instancia.html>. Acesso em: 10 maio 2006.

CITAC/EURACHEM. Guide to quality in analytical chemistry: an aid to accreditation, 2002. Eurachem. A Focus for Analytical Chemistry in Europe. Disponível em: $<$ http://www.eurachem.org/>. Acesso em: 04 jan. 2008.

CONSELHO FEDERAL DE MEDICINA. Portal Médico. Disponível em: $<$ http://www.portalmedico.org.br/php/pesquisa_resolucoes.php $>$. Acesso em datas diversas.

DATASUS. Disponível em: <www.datasus.gov.br>. Acesso em datas diversas.

FOOD AND DRUG ADMINISTRATION - FDA. Guidance for industry. Analytical procedures and methods validation. Center for Drug Evaluation and Research - CDER, 2000. Disponível em: <www.fda.gov/cber/gdlns/methval.pdf>. Acesso em: 02 jan. 2008.

FALK, João Werner; CARVALHO, Lenine Alves de; SILVA, Letícia Rodrigues da; PINHEIRO, Sebastião. Suicídio e doença mental em Venâncio Aires/RS: Conseqüência do uso de agrotóxicos organofosforados: Relatório preliminar de pesquisa. Disponível em: <http://galileu.globo.com/edic/133/agro2.doc>. Acesso em: 10 de janeiro de 2007.

GONÇALVES, E. B.; CASTRO, I. M. Desenho esquemático para programas de qualidade em laboratório de análises. Ciência e Tecnologia de Alimentos (online), v. 18, nº 1, p. 121126, 1998 Scielo Brazil Disponível em: $<$ www.scielo.br/scielo.php?script=sci_arttext\&pid=S0101-20611998000100025\& $\operatorname{lng}=$ en \&nrm=iso $>$. Acesso em: 05 jan. 2008.

ICH - International Conference on harmonization of technical requirements for registration of pharmaceuticals for human use - Harmonized Tripartite Guideline, Topic Q2B. Validation of analytical procedures: Methodology. National Institute of Health Sciences. Disponível em: <www.nihs.go.jp/drug/validation/q2bwww.html>. Acesso em: 02 jan. 2008.

INSTITUTO ADOLFO LUTZ. Disponível em: <www.ial.sp.gov.br>. 
INSTITUTO NACIONAL DE METROLOGIA, NORMALIZAÇÃO E QUALIDADE INDUSTRIAL - INMETRO. Orientações sobre Validação de Métodos de Ensaios Químicos. DOQ-CGCRE-008. Faculdade de Farmácia da UFMG. Disponível em: <www.farmacia.ufmg.br/lato/downloads/validacao_inmetro.pdf $>$. Acesso em: 02 jan. 2008.

LOPES, Homero Jackson de Jesus. Garantia e controle de qualidade no laboratório clínico. Gold Analisa. Disponível em: $<$ http://www.goldanalisa.com.br/publicacoes/Garantia_e_Controle_da_Qualidade_no_Lab oratorio_Clinico.pdf>. Acesso em: 20 dez. 2007.

LOPES, Marilu; GABRIEL, M. M.; BARETA, G. M. S. Cadeia de custódia: uma abordagem preliminar. Sistema Eletrônico de Revistas da UFPR. Disponível em: $<$ http://ojs.c3sl.ufpr.br/ojs2/index.php/academica/article/viewFile/9022/6315>. Acesso em: 26 nov. 2007.

MCREADY, Peter. Disponível em: <http://petermccready.com/>. Acesso em datas diversas.

MINISTÉRIO DA SAÚDE. Portal da Saúde. Disponível em <www.dtr2001.saude.gov.br/svs/sis/sis00sim.htm>. Acesso em datas diversas.

MOREL, Pierre. Validação de incertezas. Agência Nacional de Vigilância Sanitária. Disponível

em:

$<$ www.anvisa.gov.br/reblas/cursos_gglas/validacao_incertezas_pierre_2.pdf>. Acesso em: 10 dez. 2007.

NÚCLEO DE ATENÇÃO AO SUICÍDIO - NAS. Instituto Philippe Pinel. Prevenção do suicídio: uma experiência de intervenção terapêutica aos sobreviventes e familiares. Secretaria Municipal de Saúde do Rio de Janeiro - Coordenação de Saúde Mental. Disponível em: $<$ http://www.ccs.saude.gov.br/sociedadeviva/itinerancia/campogrande/matogrosso $\% 20 \mathrm{do}$ \%20sul\%20vers\%C3\%A3o\%202.pdf>. Acesso em: 22 out. 2008.

PASSOS, Renato Santos. Era uma vez - XIV O coletivo. Santos Passos. Disponível em: $<$ http://www.santospassos.blogspot.com/2004/10/era-uma-vez-xivo-coletivo.html>. Acesso em: 10 jan. 2006.

POLÍCIA reconstitui estupro em hospital de SP. Terra. Disponível em: $<$ http://noticias.terra.com.br/brasil/interna/0,,OI2470594-EI5030,00.html>. Acesso em: 21 out. 2008.

AS PROVAS da tortura. Revista Isto É, São Paulo, n 1.832, 25/01/06 - coluna: A semana. Terra. Disponível em: <www.terra.com.br/istoe/1892/1892_semana_02.htm>. Acesso em: 28 jan. 2006. 
SAMPAIO, Marcelo. Normas e procedimentos para a computação forense. Disponível em: <http://www.dpt.ba.gov.br/dpt/web/ICAPInterna.jsp?ModId=70>. Acesso em: 26 nov. 2007.

SESDEC-RJ. Atenção às tentativas de suicídio na rede de hospitais estaduais do Rio de Janeiro. Secretaria de Saúde de Estado e Defesa Civil do Rio de Janeiro. Disponível em: $<$ http://www.webdimensions.com.br/conass/atencao_as_tentativas_de_suicidio_rede_hospi tais_estaduais.pdf>. Acesso em: 22 out. 2008.

SOBEL, Henry I. Porquês do Judaísmo. Congregação Israelita Paulista. Disponível em: <www.cipsp.org.br>. Acesso em: 10 jan. 2006.

TRAÍDO pelo teclado. Revista Época, São Paulo, no 401, p. 11, jan. de 2006. $<$ http://revistaepoca.globo.com/Revista/Epoca/0,,EDG72941-6014,00-

PRIMEIRO+PLANO.html>.

USA Suicide: 2000 - Official final data. American Association of Suicidology. Disponível em <www.suicidology.org>. Acesso em: 20 jan. 2006. 